\title{
THE \\ WHISTLER BOOK
}

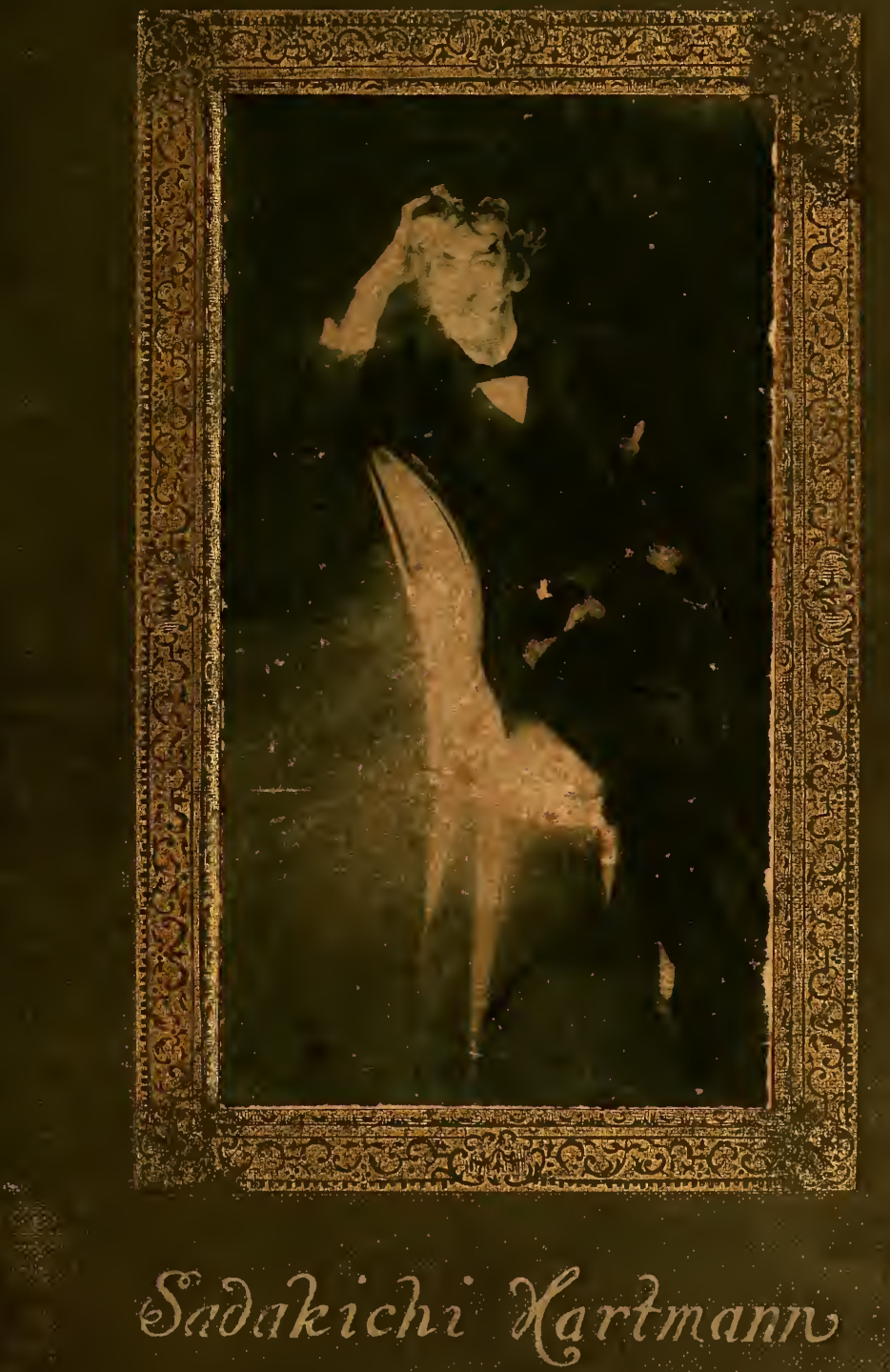







\section{THE WHISTLER BOOK}




\section{WORKS OF \\ SADAKICHI HARTMANN}

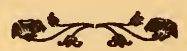

Shakespeare in Art . $\quad \$ 2.00$

Japanese Art • . • . 2.00

The Whistler Book $\quad$ - 2.50

A History of American Art. 2 vols. 4.00

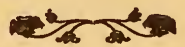

L. C. PAGE \& COMPANY

53 BEACON ST., BOSTON, MASS. 


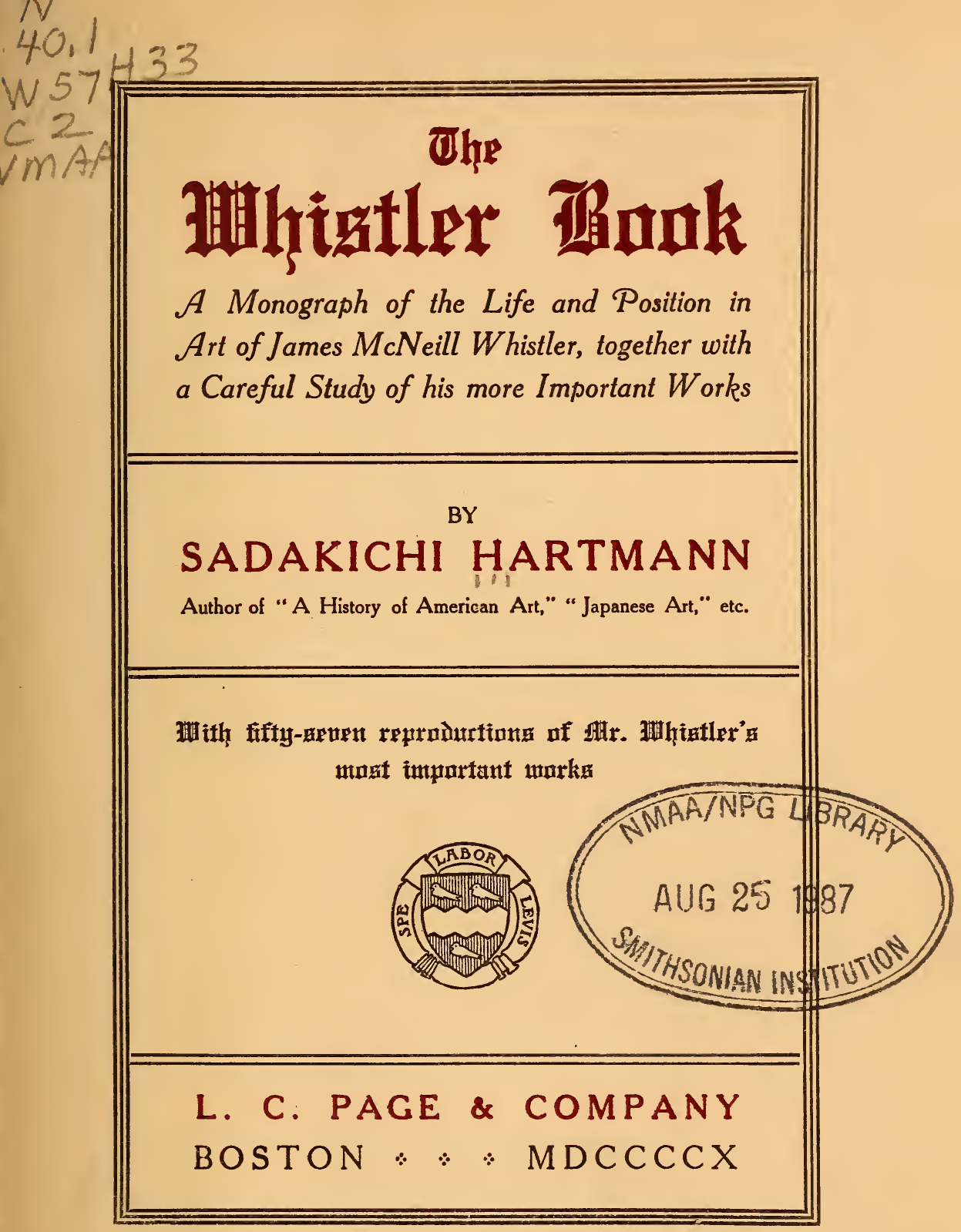


Copyright, 1910,

By L. C. Page \& Company. (INCOR PORATED)

Entered at Stationer's Hall, London

All rights reserved

First Impression, October, 1910

Electrotyped and Printed by THE COLONIAL PRESS C. H. Simonds \& Co., Boston, U.S.A. 
TO

THOSE PAINTERS

UPON WHOSE SHOULDERS

THE BLACK MANTLE OF

WHISTLER'S MUSE

MAY FALL 



\section{CONTENTS}

CHAPTER PAGR

I. Introductorx - White Chrysanthemums . . 1

II. Quartier Latin and Chelsea . • • . 6

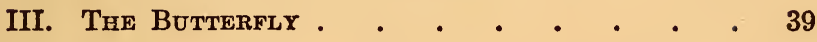

IV. The Art of Omission . • . • . 58

V. On Light and Tone Problems . . . . 81

VI. StMphonies IN INTERIOR Decoration . . 100

VII. Visions AND Identifications . . . . . 121

VIII. In QUest of Line Expression . • • . 147

IX. Moss-Likn Gradations . . . . . . 168

X. WHistlen's ICONOCLASM . . • • • . 182

XI. As His Friends Knew Him . . . . 209

XII. The Story of the Beautiful . . . . 233

Bibliography • . . . . . . . 253

Principal Magazine Articles . $\quad$. $\quad$. 259

Principal Paintings $\quad . \quad$. $\quad . \quad$. 262

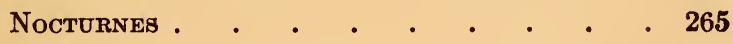

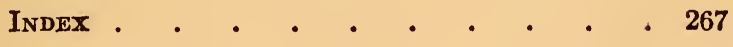





\section{LIST OF ILLUSTRATIONS}

PAGE

Portrait of James McNeill Whistler, by Boldini (See

page 230) . . . . . . . Frontispiece

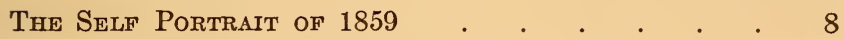

Pen and Ink Sketch, Made at West Point . . . 11

Drawing Made for the United States Coast and

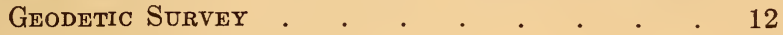

Portrait Sketch of Fantin-Latour . . . . 14

"Hommage À Delacroix," by Fantin-Latodr . . 17

The Woman IN White . . . . . . . . 19

Owned by John H. Whittemore.

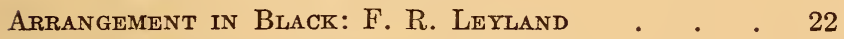

National Gallery, Washington.

Jo (ЕтсHING) . . . . . . . . . . . . 28

WAPPING WharF (Etching). . . . . . . 36

Harmony in Green and Rose: The Music Room . 44

Owned by Frank J. Hecker.

Lange Leizen of the Six Marks: Purple and Rose . 49

Owned by John G. Johnson.

The Princess of the Porcelain Land . . . . 50

National Gallery, Washington.

Symphony in White, II: The Little White Girl . 53 Owned by Arthur Studd.

On the Balcony: Variations in Flesh-Colodr and GREen . . . . . . . . . . 54

National Gallery, Washington.

Nocturne in Black and Gold: The Faliing Rocket . 58

Owned by Mrs. Samuel Untermyer.

Nocturne in Blue and Gold: Old Battersea Bridge 67 Tate Gallery, London. 
Nocturne in Gray and Gold: Chelsea, Snow . . 70

Nocturne in Blue and Silver . . . . . . 74

LADY IN GRAY . . . . . . . . . . $\quad . \quad$. 83

Courtesy of the Metropolitan Museum, New York.

"L'ANDALUSIENNE" . . . . . . . . 86

Owned by John H. Whittemore.

Sir Henry Irving as Philip II . . . . . 90

Courtesy of the Metropolitan Museum, New York.

Arrangement in Black and White: Lady Meux (No. 1) 94

Arrangement in Black: Senor Pablo Sarasate . 97

Carnegie Art Institute, Pittsburg.

Shutter Decoration, Peacock Room . . . . 104

Arrangement in Gray and Green: Miss Alexander . 109

Eagle Wharf (Etching) . . . . . . . 118

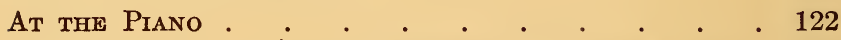

Arrangement in Black and Brown: Miss Rose Corder 128

Owned by Richard A. Canfield.

Arrangement in Black: Lady Archibald Campbell

(The Yellow Buskin) . . . . . . . 137

Wilstach Gallery, Philadelphia.

Arrangement in Black and Gold: Comte de MontesQUIOU . . . . . . . . . . . . 142

Owned by Richard A. Canfield.

Arrangement in Black and Gray: Thomas Carlyle . 144 City Art Gallery, Glasgow.

Arrangement in Black and Gray: The Artist's

Mother . . . . . . . . . . . 146

Luxembourg Gallery, Paris.

“La Vieillo aux Loques" (Etching) . . . . 149

Street in Saverne (Etching) . . . . . . . 150

Portrait of Drouet (Etching) . . . . . . 153

Black Lion Wharf (Etching) . . . . . . 154

Wapping, on the Thames (Etching) . . . . 160 
Old Hungerford Bridge (Etching) . . . . 162

The Silent Canal (Etching) . . . . . . 164

View of Amsterdam (Etching) . . . . . . 166

Nocturne (Lithograph) . . . . . . . 170

LitTle Rose of LyMe Regis . . . . . . 175

Boston Museum of Fine Arts.

Study of Nude Figure (Chalk Drawing) • • 176

Pastel Study . . . . . . . . . . 178

Owned by Th. R. Way.

Archway, Venice (Pastel) . • • . . . . 182

Owned by Howard Mansfield.

The Japanese Dress (Pastel) . . . . . . 186

Owned by Howard Mansfield.

Mr. Kennedy: Portratt Study . . . . . 192

Courtesy of the Metropolitan Museum, New York.

The Lime Burner (Etching) . . . . . . 198

Portrait of Stéphane Mallarmé (Lithograph) . . 209

Arrangement in Flesh-colour and Black: Theodore

DURET . . . . . . . . . . 214

The Unsafe Tenement (Etching) . . . . . . 220

In the Sunshine (Etching) . . . . . . . . 226

The Pool (Etching) .

Arrangement in Black and White: “L'Americaine" 238

The Fiddler (Etching) . . . . . . . . . . 246

Nocturne in Brown and Silver: Old Battersea

BRIDGE . . . . . . . . . . 248 




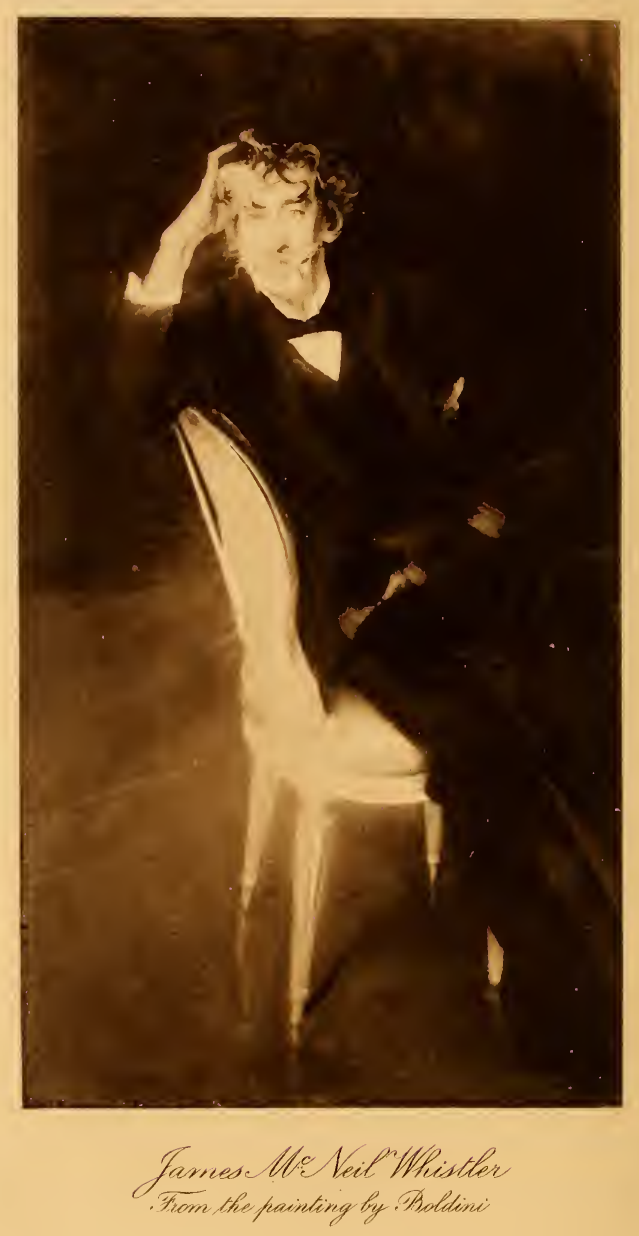




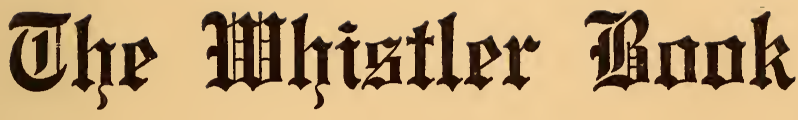

\section{CHAPTER I. - INTRODUCTORY}

WHITE CHRYSANTHEMUMS ${ }^{1}$

The white chrysanthemum is my favourite flower. There are other flowers, I grant, perhaps more beautiful, which I cannot help admiring, but the white chrysanthemum somehow appeals to me more than any other flower. Why? That is more than I can tell. The unconscious movements of our soul activity cannot be turned into sodden prose. What would be the use of having a favourite flower if one could give any reason for liking it? It merely reveals that part of our personality, not to be logically explained, which rises within us like the reminiscences of some former soul existence. There are colours and certain sounds

'Published originally in "Camera Work," 1903. 
and odours which effect me similarly. Whenever I gaze at a white chrysanthemum, my mind becomes conscious of something which concerns my life alone; something which I would like to express in my art, but which I shall never be able to realize, at least not in the vague and, at the same time, convincing manner the flower conveys it to me. I am also fond of displaying it occasionally in my buttonhole; not for effect, however, but simply because I want other people to know who I am; for those human beings who are sensitive to the charms of the chrysanthemum, must hail from the same country in which my soul abides, and I should like to meet them. I should not have much to say to them - souls are not talkative - but we should make curtsies, and hand white chrysanthemums to one another.

Whistler was busy all his life painting just such white chrysanthemums. You smile? Well, I think I can persuade you to accept my point of view.

You are probably aware that Whistler was opposed to realism. The realists endorse every faithful reproduction of facts. Also, Whistler believed all objects beautiful, but only under certain conditions, at certain favoured moments. It is at long intervals and on rare occasions that nature and human 
life reveal their highest beauty. It was Whistler's life-long endeavour to fix such supreme and happy moments, the white chrysanthemums of his æsthetic creed, upon his canvases. Have you never seen a country lass and thought she should be dressed up as a page - her limbs have such a lyrical twist, as George Meredith would say - she should stand on the steps of a throne, and the hall should be illuminated with a thousand candles? Have you never met a New England girl, and thought that she was ill-suited to her present surroundings, that she would look well only standing on the porch of some old Colonial mansion, in the evening, when odours of the pelargoniums and gladioli begin to fill the garden? Have you not noticed that a bunch of cut flowers which looks beautiful in one vase may become ugly in another? And how often has it not happened to all of us that we were startled by a sudden revelation of beauty in a person whom we have known for years and who has looked rather commonplace to us? Suddenly, through some expression of grief or joy, or merely through a passing light or shadow, all the hidden beauty bursts to the surface and surprises us with its fugitive charms. Whistler's "At the Piano," "The Yellow Buskin," "Old Battersea Bridge," "Chelsea: 
Snow," are painted in that way. Could you imagine his "Yellow Buskin Lady" in any other way than buttoning her gloves, and glancing back, for a last time, over her shoulder, as she is walking away from you into grey distances! That peculiar turn of her body reveals the quintessence of her beauty. And that is the reason why Whistler has painted her in that attitude. Thus every object has its moment of supreme beauty. In life these moments are as fugitive as the fractions of a second. Through art they can become a permanent and lasting enjoyment.

The ancient Greek believed in an ideal standard of beauty to which the whole universe had to conform. The modern artist, on the other hand, sees beauty only in such moments as are entirely individual to the forms and conditions of life he desires to portray. And as it pains him that his conception of beauty will die with him, he becomes an artist through the very endeavour of preserving at least a few fragments of it for his fellow-men. With Whistler, this conception was largely a sense for tone, a realization of some dream in black and silvery grey, in pale gold or greenish blues. A vague flare of colour in some dark tonality was, to him, the island in the desert which he had to seek, unable to rest until he had found 
it. He saw life in visions, and his subjects were merely means to express them. In his "Lady Archibald Campbell" he cared more for black and grey gradations and the yellow note of the buskin than for the fair sitter. The figure is, so to speak, invented in the character of the colour arrangement. Whistler once said he would like best to paint for an audience that could dispense with the representation of objects and figures, with all pictorial actualities, and be satisfied solely with the music of colour.

And why should we not profit by his lesson, and learn to look at pictures as we look at the flush of the evening sky, at a passing cloud, at the vision of a beautiful woman, or at a white chrysanthemum! 


\section{CHAPTER II}

QUARTIER LATIN AND CHELSEA

During Jean François Raffaelli's sojourn in America I had occasion to ask him the rather futile question of how long it took a painter in Paris to become famous. Of course I referred to a man of superior abilities, and meant by fame an international reputation. He answered twenty years at least, and I replied that about twenty years more would be needed in America.

Whistler had a long time to wait before fame knocked at his door, although he had a local reputation in London and Paris at forty. He was known as a man of curious ways, and an excellent etcher; but, with the exception of two medals, he had received no honours whatever for his paintings. His work still impressed by its novelty; but he had not yet captivated the public. He still had to fight for recognition, and, as long as a man has to do that, he is neither a popular nor a successful man. 
Toward the middle of the seventies recognition appeared to come more readily. He seemed to know everybody of note, and everybody seemed to know him. His writings and controversies attracted considerable attention, his supremaćy as an etcher had been admitted, and his pictures became more widely known. He had gathered around him a number of wealthy patrons, who were connoisseurs and keen appreciators of his talents. He was so successful financially in the latter part of his life that he had residences and studios in Paris as well as in London. At Paris his headquarters were in the rue du Bac. In London he had various quarters, - on Fulham Road, Tite Street, Langham Street, Alderney Street, St. Regents Street, The Vale, etc. Going from one place to the other as his moods dictated to him, with an occasional sketching trip to Venice, to Holland or the northern parts of France, he lived the true life of the artist, quarrelled with his friends, delighted his admirers with the products of his fancies, and astounded the intelligent public on two continents with the caprices of his temper. Strange to say, even at that time, his best work had already left his easel. He was busy with minor, but not less interesting, problems and devoted most of his time to etchings, 
pastels and lithographs. But it was at this time that his "Ten O'clock" and "The Gentle Art of Making Enemies" were published; and when his "Carlyle" found its way to the Glasgow City Gallery, and "The Portrait of the Artist's Mother" was purchased by the Luxembourg Gallery at Paris.

Comparatively little is known of Whistler's private life. I wonder how many of his admirers, excepting his personal friends, were acquainted during his life-time with the fact that he was married, and could tell whom he had married. He remained a bachelor until his fifty-fourth year, when he married the widow of his friend E. W. Godwin, the architect of the "White House." She was the daughter of John Bernie Philip, a sculptor, and was herself an etcher. They were married on Aug. 11, 1888. Eight years later his wife died, May 10th, 1896.

How this man of moods and capricious tastes got along in married life the general public has never found out. His friends assure us that it was a happy union and that he was deeply devoted to his wife. He has painted her repeatedly, but the pictures do not betray any domestic secrets to the public. Although Whistler was fond of notoriety, and managed to keep himself continually before the pub- 


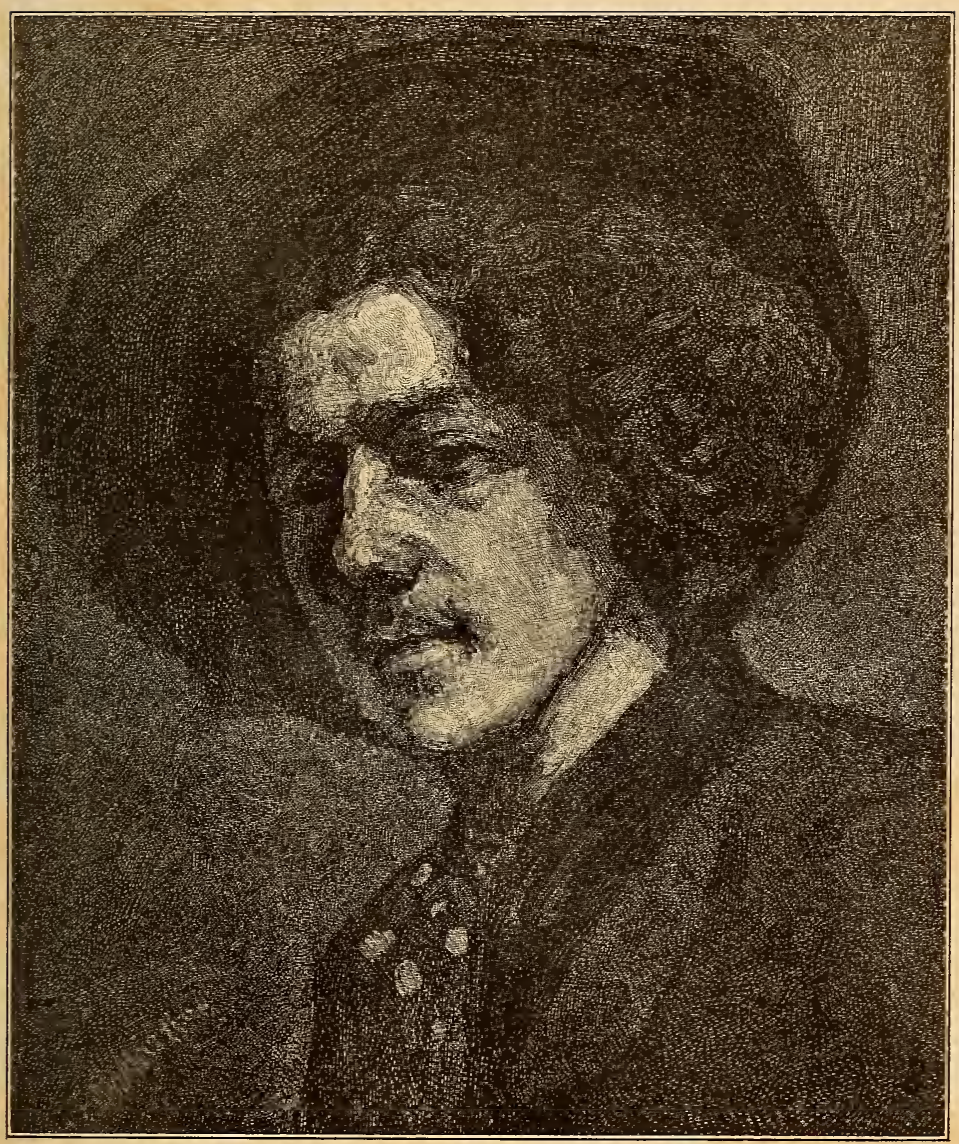

THE SELF PORTRAIT OF 1859. 

lic, - in the fullest limelight, so to speak, he never allowed personal news and the details of his everyday life to claim the attention of the public. All his innumerable feuds and press displays were related to his work, - to his completed pictures and theories of art. $\mathrm{He}$ liked to play upon his personality, but only as far as the artist was concerned. He was peculiarly free from the taint of exploiting his own domestic affairs. He hated biographies and all references to his family life. Even in his feuds with his old friends, F. R. Leyland, and his brother-in-law, Seymour Haden, when he brutally dragged apparent private matters into the glare of publicity, the discriminating observer will notice that his controversies, sarcasms and interpretations refer solely to "art situations" and never descend to the low depths of personal abuse.

James McNeill Whistler was born on July 10th (some say July 11th), 1834, at Lowell, Mass. One of his ancestors, a Dr. Whistler, is frequently mentioned in Pepys' delicious diary. He was baptized James Abbott Whistler in the Church of St. Anne, at Lowell. His father, Major George Washington Whistler, was a civil engineer and, during the first eight years of James' life, moved from Lowell to Stonington, Connecticut, thence to Spring- 
field, Massachusetts, and, finally, in 1842, went to Russia to superintend the construction of the railroad from St. Petersburg to Moscow. The following year the family sailed from Boston to make their home in St. Petersburg.

This was the first impression the boy Whistler received from the outside world, and no doubt the trip across the Atlantic and the sojourn in a foreign country made a lasting impression upon him. Russia, with its quaint old civilization and touches of barbaric splendour, was the country to excite the imagination of any boy, and the change from a New England village life to the metropolitan turmoil of St. Petersburg would have left imperishable traces in any receptive mind. The father was paid lavishly and the boy was brought up in luxury.

The first report of any art talent in the boy can be found in the reference, mentioned by several biographers, to his taking lessons at the Imperial Academy of Sciences at St. Petersburg. It had probably no particular bearing on his career, since art teaching in Russia was traditional, and probably consisted of nothing but drawing from wooden models and plaster casts. It informs us, however, of the fact that he became familiar with the rudiments of 


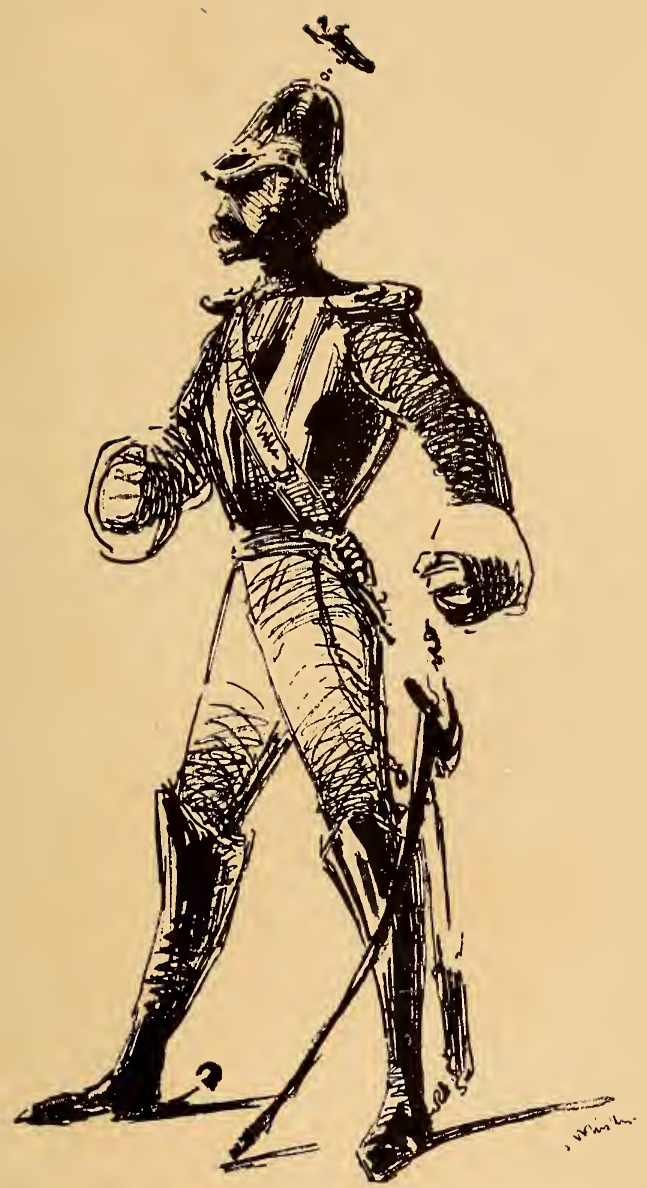

PEN AND INK SKETCH, MADE AT WEST POINT. 

drawing at an early age. Of by far greater importance to his development were his visits to the Hermitage. There he saw for the first time Velasquez and he learnt to differentiate between painters who could paint and such who could only tell a story in line and colour.

On the death of the father, April 7th, 1849, the family returned to the United States and settled in Stonington, Conn., and young Whistler attended school at Pomfret, Conn. In 1851, seventeen years old, he entered the United States Military Academy at West Point and was enrolled as James McNeill Whistler, taking his mother's maiden name as a middle name. Like Poe, he does not seem to have been over-fond of a routine military career. No doubt something of the artist's temperament had awakened in him, and, like all young talents, he objected to regulated study, and tried to satisfy the vague aspirations of his unsettled consciousness with work that was more congenial to him.

He left West Point in July, 1854. The technical discharge was "deficiency in chemistry," but it was probably general unfitness for a career of discipline and exactness. Through some influence he received an appointment in the drawing division of the United States Coast and Geodetic Survey at 
Washington, D. C., at the salary of $\$ 1.50$ a day, but he resigned two months later. The government records show that he worked only six and a half days in January and five and three-quarter days in February. He apparently had no taste for map designing and bird's-eye views. It is said he paid more attention to the deliberate drawing of little trees and detail than to the typographic facts.

His military career had come to an end; he had to do something else, and he felt that he had to become an artist at any price. Money was not over abundant in the Whistler family, but there was sufficient to allow him a few years' leisure to study art wherever he chose, and so he went to Paris, and joined the youthful band of artists, who fought for modernism and a new technique, and the glory of the métier, with an enthusiasm, a bravery and devotion that has rarely been encountered. There he lived the regular student life for four years. He entered the atelier of Charles Gleyre, but only stayed for a short while. He preferred to look about for himself. At one time he and young Tissot made a copy of Ingres" "Angelique."

Whistler arrived in France shortly after the coup d'état. Paris was not then what she is to-day. None of the chain of boulevards 


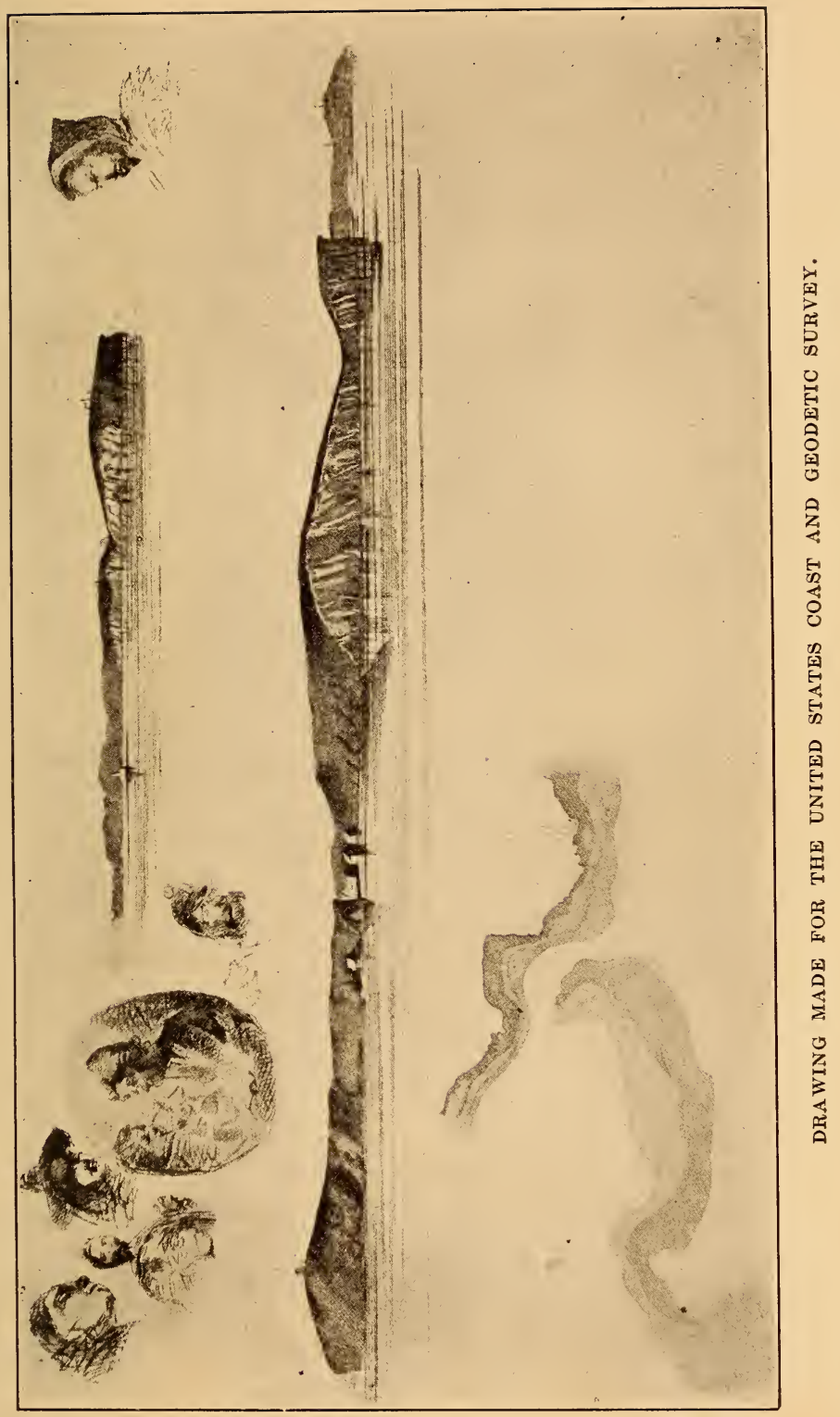



around the centre of the town, not even the boulevard of St. Michael, which became the great thoroughfare for artists, were in existence in their present condition. But Whistler had come at the time when Paris was being reconstructed into one of the most beautiful cities of the world, and, when the Imperial régime unfolded its full splendour. Paris became intoxicated with its own beauty, and the social life blossomed forth in all its elegance and frivolity.

During 1857-58 Whistler had a studio in the rue Compagne Première, boarding in Madame Lalouette's pension in the rue Dauphine. For some time he also shared quarters with FantinLatour, who, with Legros, was his most intimate friend during his student years. They saw each other daily, and it was on one of these occasions that he made the humourous sketch of Latour, depicting him on a cold winter morning seated in bed, drawing, all dressed, with a top hat on his head.

They were the days of Henri Murger's "La Vie Bohême," of bon camaraderie, eccentric days when every man sought to make his mark by peculiarities of dress, soft felt Rubens' hats, velvet cloaks with the ends thrown over the shoulders, and other exotic garments. In one exhibition, in sheer audacity of youth, Whis- 
tler appeared dressed in a Japanese kimono. Think of a man in a kimono in 1855! Whistler at that time was a true Bohemian. His little studio was his workshop, his temple, his parlour, his playhouse and his dormitory. $\mathrm{He}$ frequented the queer, interesting quarters that students seek, - quaint old cafés where food was good as well as cheap, and character abundant.

What is there so fascinating about the Bohemian's life? The Philistine, I fear, generally considers him an eccentric, indolent man, with no thought for the morrow, no notion of economy, no home save the place which affords him temporary shelter. He never stops to think that the Bohemians are the men who make our songs, who paint our pictures, chisel marvellous creations out of wood and stone, compose our sweetest poems and write our newspapers. It is a grievous mistake to assume that they are merely a lot of idle, luckless fellows. They are men with brains of good quality, and hearts in the right place. All classes and trades of men have burdened the world with their wants and woes. Not so the Bohemian. $\mathrm{He}$, too, has his heartaches and bitter disappointments, but who ever hears of them? The humourous tale over which you laugh so heartily, recounting the adventures of a poet in 


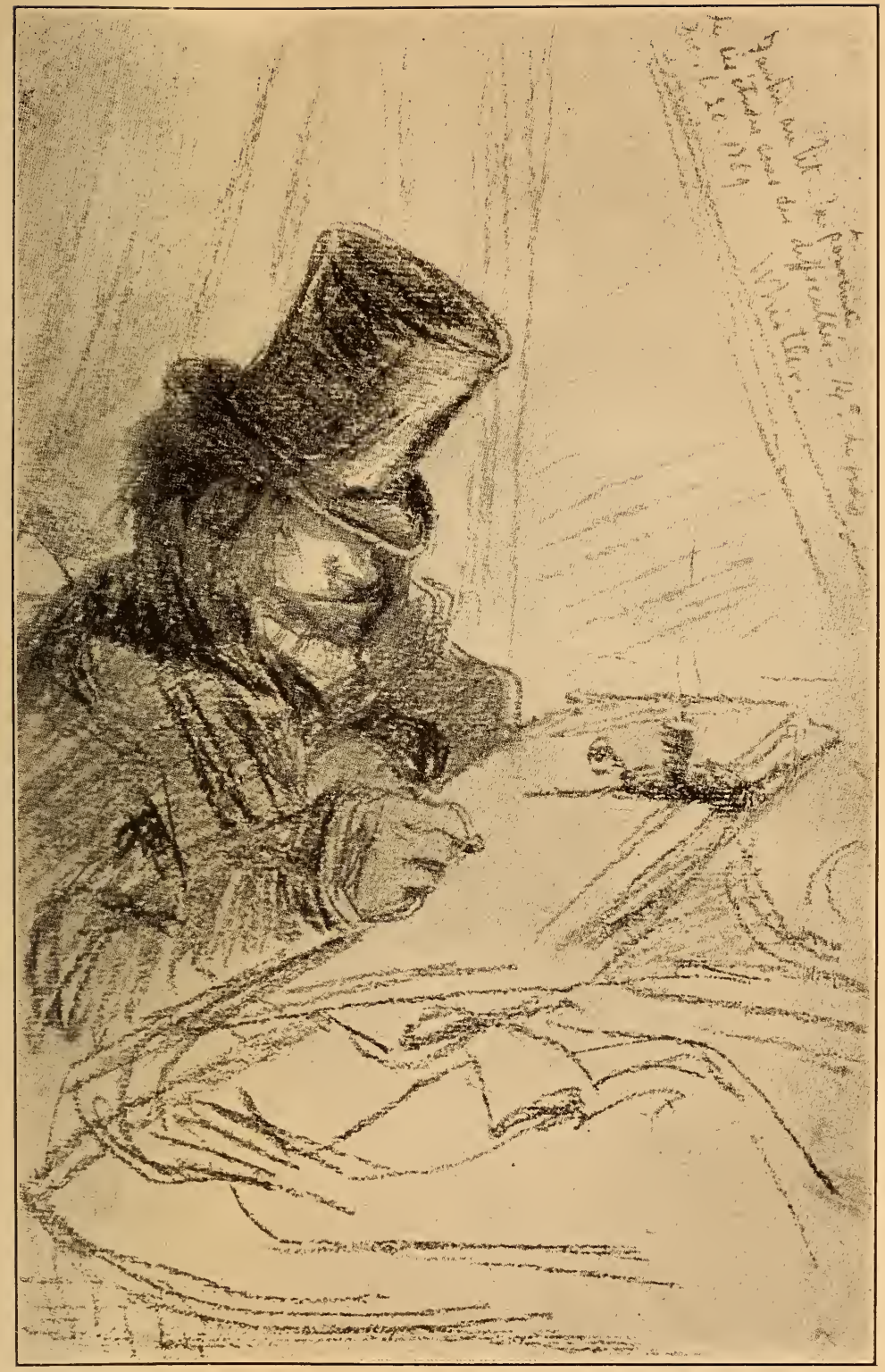

PORTRAIT SKETCH OF FANTIN-LATOUR. 

search of a publisher, had the author's personal experience for a basis. He could not sell his poems, but needed bread; so, out of his misfortune, he had good cheer. The ordinary man, rebuffed by fortune, would sit down and mourn himself into illness. The Bohemian utilizes these very reverses, and both he and the world are the merrier eventually for them. He lives in a world distinct from that of common men. Talent, love of comradeship, a sunny disposition - these are the magnets that will draw one toward it. It has its obligations, its trials, its code of honour, rigid as the most unbending militarism; but there is charm of companionship and an absence of jealousies and pettiness within it that makes you powerless to rid yourself of its enchantments. The Bohemian's life is apart from yours, but why chide him for it? He builds on the ruins of no other man's life, he feeds on no man's scandals, he exults in no man's misfortunes, but goes on his way, imbibing the sweetness of life from every flower, and, in his own way, scattering the perfume broadcast. He does half our thinking and originates two-third of all the movements for the social reclamation of the world. $\mathrm{He}$ is no hypocrite before the mighty, nor heartless in the face of the unfortunate. He covets no 
man's goods, but lives his own quiet, interesting, exquisite life. He asks only a share of the sunlight of life. In du Maurier's "Trilby" we find a sympathetic description of the art life of that period, but also a rather despicable type of a man, "Joe Sibley," by name, who always pretends but never does a thing and who was meant for a ludicrous satire on young Whistler (a character which was eliminated on Whistler's request from the second edition).

It is easy to draw a mental picture of him as he looked at that time. I see him studying in the Louvre, in a loose black blouse with low turned down collar and a soft black hat on his long, slightly curled hair, lost in wonder before a painting by Leonardo; or strolling along the Boulevards, cane in hand, ogling the beautiful women, and dreaming of designing some dress for the Empress Eugenie, passing by in an open phaeton. And how enthusiastic he got, no doubt, over some Japanese print or Chinese vase in some curio shop.

A certain trigness, smartness, acquired very likely at West Point where the cadets change their white duck trousers several times a day, induced him, even at this time, to take special care over the fit of his coat.

In 1859 he went with several fellow students, Fantin-Latour, Legros, and Ribot, to 


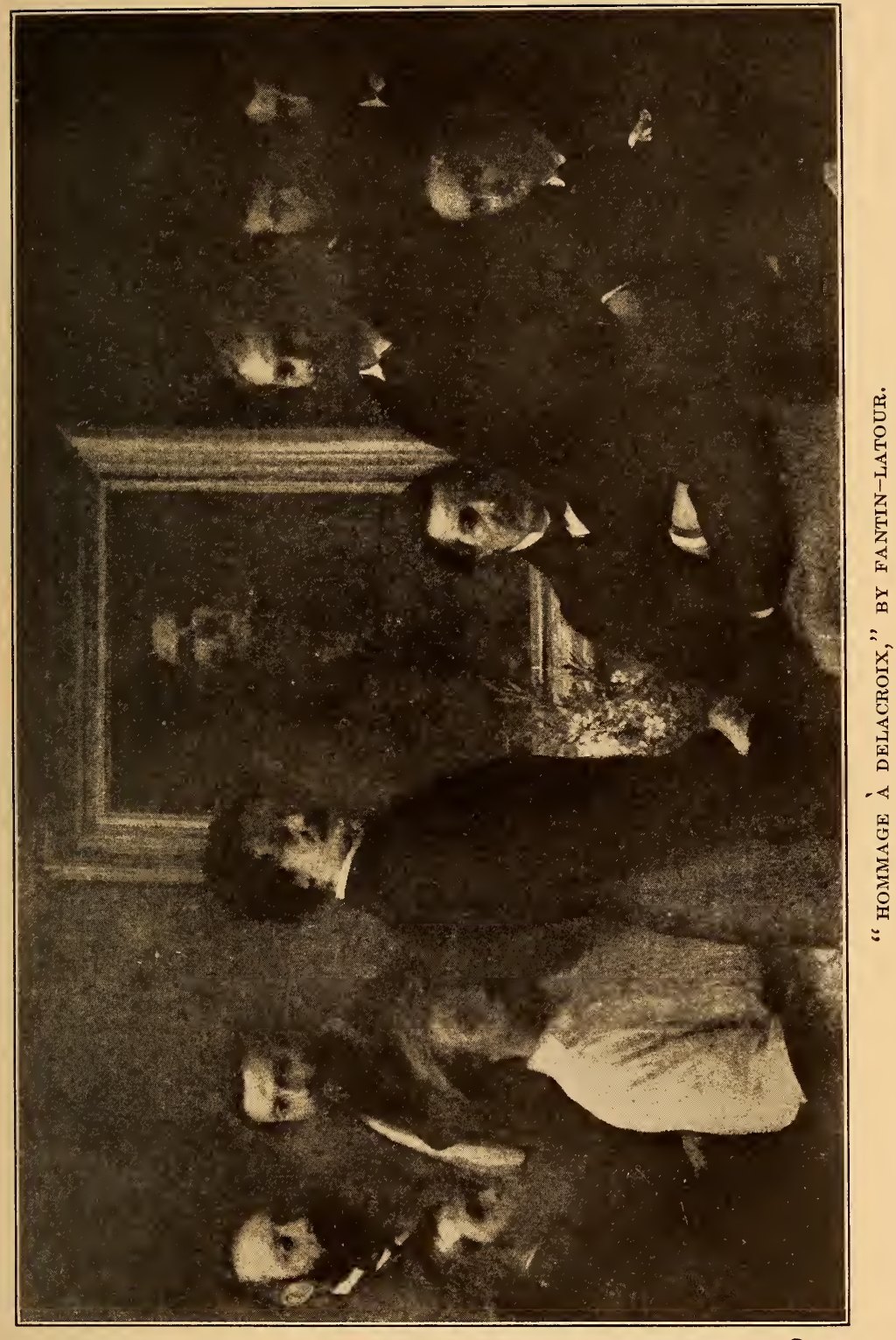


1 
Bonvin's studio to work from the model, under the direction of Courbet. At that time he was interested in types. He painted a "Fumette," a little grisette of the Quartier Latin, and the "Mother Gerard," who in her younger days had been a maker of pretty verses, but, reduced in circumstances, had become a flower vender at the Bal Bullier. Among his friends and associates we find the names of Legros, Cordier, Duranty, the etcher Bracquemond, inventor of the "pen and ink" process, de Balleroy, Champfleury, Manet and Baudelaire. They were all young men of talent, plein d'avenir. Fantin-Latour made a group-portrait of them, including Whistler and himself, seated and standing, assembled about a portrait of Delacroix. The canvas was exhibited at the Salon of 1864 as an "Hommage à Delacroix."

Whistler's step-sister had married Seymour Haden, the etcher, and Whistler, paying them a visit in 1859, stayed in London. The four years in Paris had matured him, and he knew how to accomplish something beyond the routine studio work. In 1862 he exhibited for the Royal Academy. It was his " At the Piano," which, if not a masterpiece, is already a true and individual work of art.

Courbet still had a strong hold on him. He spent two summers with him in Trouville and 
may have derived his first lessons as a mystificateur, which part he played so successfully during life, from the French painter, for Courbet was a poseur throughout, who assumed a particular kind of dress, and who was not satisfied merely with painting pictures that offended the Academy and conventional taste, but made a special effort and took special pleasure in shocking the bourgeoisie.

Whistler also made his first trip to Holland during these years, and became enchanted with Rembrandt and Vermeer, but took a great dislike to Van der Helst. In 1859-60 youthful efforts of his had been refused at the Paris Salon; the same happened again in 1863 , but he was one of the men who scored a success at the Salon des Refusées. A number of talented painters, and among them men of genius like Manet, Cazin, Degas, Harpignies, Vollon, Pissaro, Jongkind and Bracquemond, tired of the cliquism and jury of the regular Salon, - a story which repeats itself everywhere, - decided to arrange their own exhibition. Napoleon III, in his nonchalant way a true patron of art, issued an order to arrange the exhibition of "revolt" in the same building as the official exhibition. The exhibition was a success, and even the Empress Eugenie and the court came to see it. This is really of 


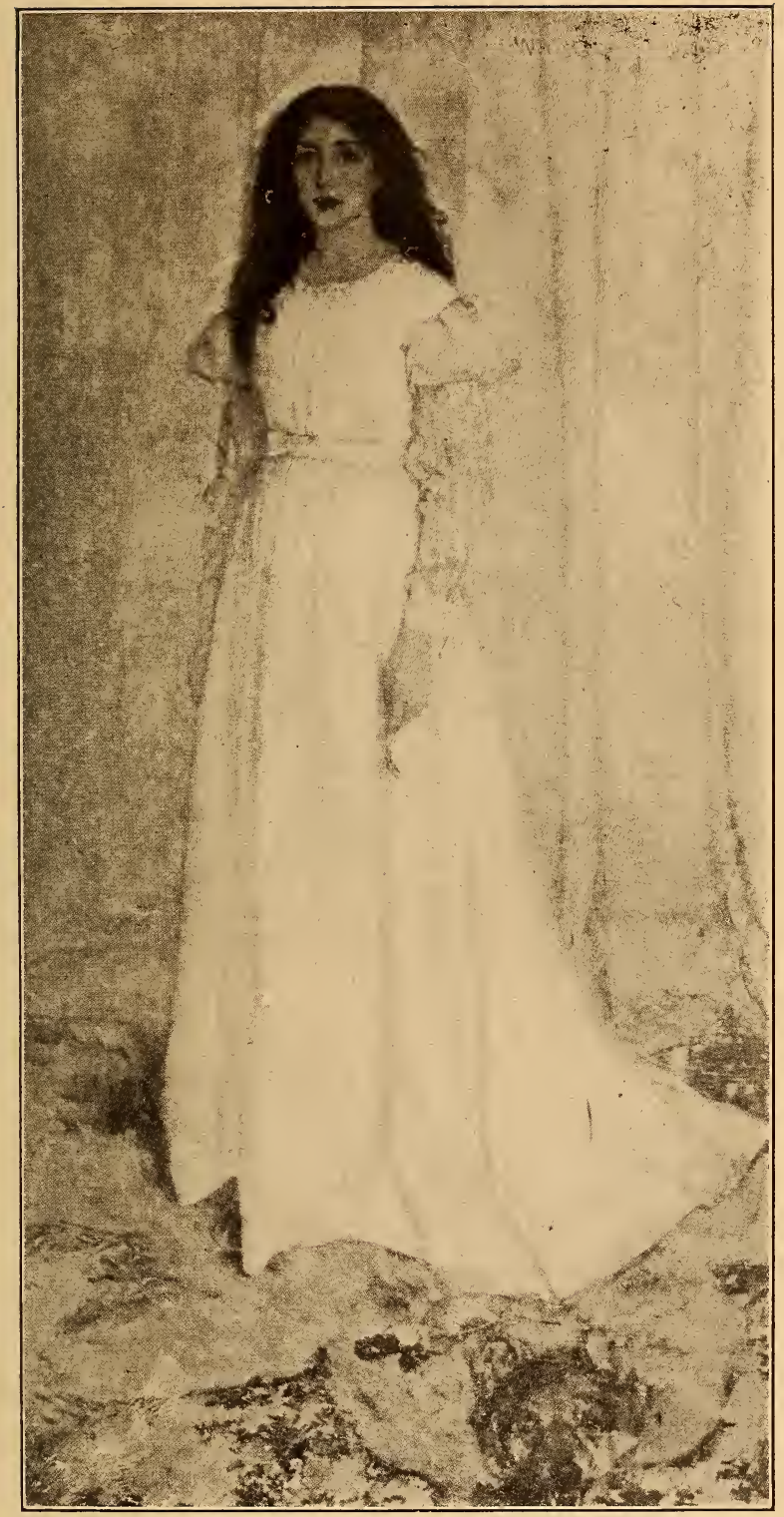

Owne d by John H. Whittemore

THE WOMAN IN WHITE. 

no significance, as nobody bought anything; but it sounds well, and biographers should never neglect to mention such incidents.

One thing is certain: Whistler's picture, "The White Girl," even with Manet's "Dejeuner sur l'Herbe" in the same room, attracted an unusual share of attention. Zola, in "L'Euvre," says that the crowd laughed in front of "La Dame en Blanc." Desnoyers thought it "the most remarkable picture, at once simple and fantastic with a beauty so peculiar that the public did not know whether to think it beautiful or ugly." Paul Mantz wrote in the Gazette des Beaux-Arts that it was the most important picture in the exhibition and called the picture a "Symphonie du Blanc" some years before Whistler adopted that title.

The exhibition of this picture represents, in a way, the turning point in Whistler's career. It was a steady ascent ever after. Before this he was unknown, and exposed to the manifold privations and vicissitudes of an artist's career. Many a day he had gone hungry and frequently could not paint for lack of material. Now things began to run a trifle smoother, although sales were still rare and money scarce. His lodgings in 7 Linsey Row (now 101 Cheyne Walk) were extremely simple and 
his studio consisted of a second-story back room.

During the next three years he worked hard, and finished a number of pictures that since then have made history. They are all in a lighter key and of brilliant colouring. The problem he seemed to be most interested in was to reproduce in relief the charm of diversified colour patches as seen in Japanese prints.

He continued to see things in this way until he made a trip to South America in 1866. Feeling, perhaps, slightly discouraged, or in need of some recreation, he and his brother set out for Chili, under the pretence of joining the insurgents à la Poe and Byron, although I hardly believe that a man of thirty-two really capable of such a wild goose chase. At all events, when they reached Valparaiso the rebellion had ceased and instead of handling a musket "our Jimmie" opened his paint box instead.

The result was startling. Impressed by the new sights of southern scenery, and in particular of the translucency and subdued brilliancy of the sky at night, he painted one of his finest nocturnes, the "Valparaiso Harbour," now at the National Gallery of Art. The darkness of night to a large extent bars colour, and furnishes a kind of tonal veil over 
all objects; but in southern countries the nights are clearer and brighter and, although forms and colours are indistinct, they remain more plainly discernible than in the blackness of our Northern nights.

After his return to London he worked hard at solving the problem of creating tone which would suggest atmosphere with as little subject matter as possible. Four years passed before he held the first exhibition of a "Variation " and "Harmony." He now began to feel his own strength. He felt that he had done something new and had the courage to coin his own titles. The method of classifying his pictures as Harmonies and Symphonies, Arrangements, Nocturnes, Notes, and Caprices, was entirely his own invention and in his earlier career did much to attract attention to his work. One year later, in 1872, exhibiting several symphonies, he included for the first time an impression of night under the title of "Nocturne." The years 1870-77 were probably the busiest and the most important ones of his whole career. They produced not only the "Nocturne," but also the "Peacock Room " and the painting which is generally conceded to be his masterpiece, the "Portrait of the Artist's Mother."

Success and fame at last knocked at his 
door. Mr. F. R. Leyland, the rich ship-owner of Liverpool, proved a generous patron. Between 1872 and 1874 he ordered portraits of himself, Mrs. Leyland and the four children. Whistler made long visits at Speke Hall, Leyland's home near Liverpool. His paintings began to sell more readily than heretofore and several orders for interior decoration had come in, among them the decoration of the music room of the famous violinist Sarasate's home in Paris. He was willing to work at anything as long as he could carry out his own ideas. He invented schemes for interior decoration and also once tried himself as an illustrator, when he made exquisite drawings of the vases, plates, cups of blue and white Nankin for the catalogue of Sir H. Thompson's collection of porcelain. (Ellis and Elvey, London, 1878.)

After leaving 7 Linsey Row, during the years 1866-1878, Whistler lived in several other houses situated in the Chelsea district, for like so many of us that have got used to a certain part of the city, he could never get away from it. The most pretentious of these abodes was the "White House" which became one of the centres of attraction in the art life of London.

There he gave his famous Sunday morning 


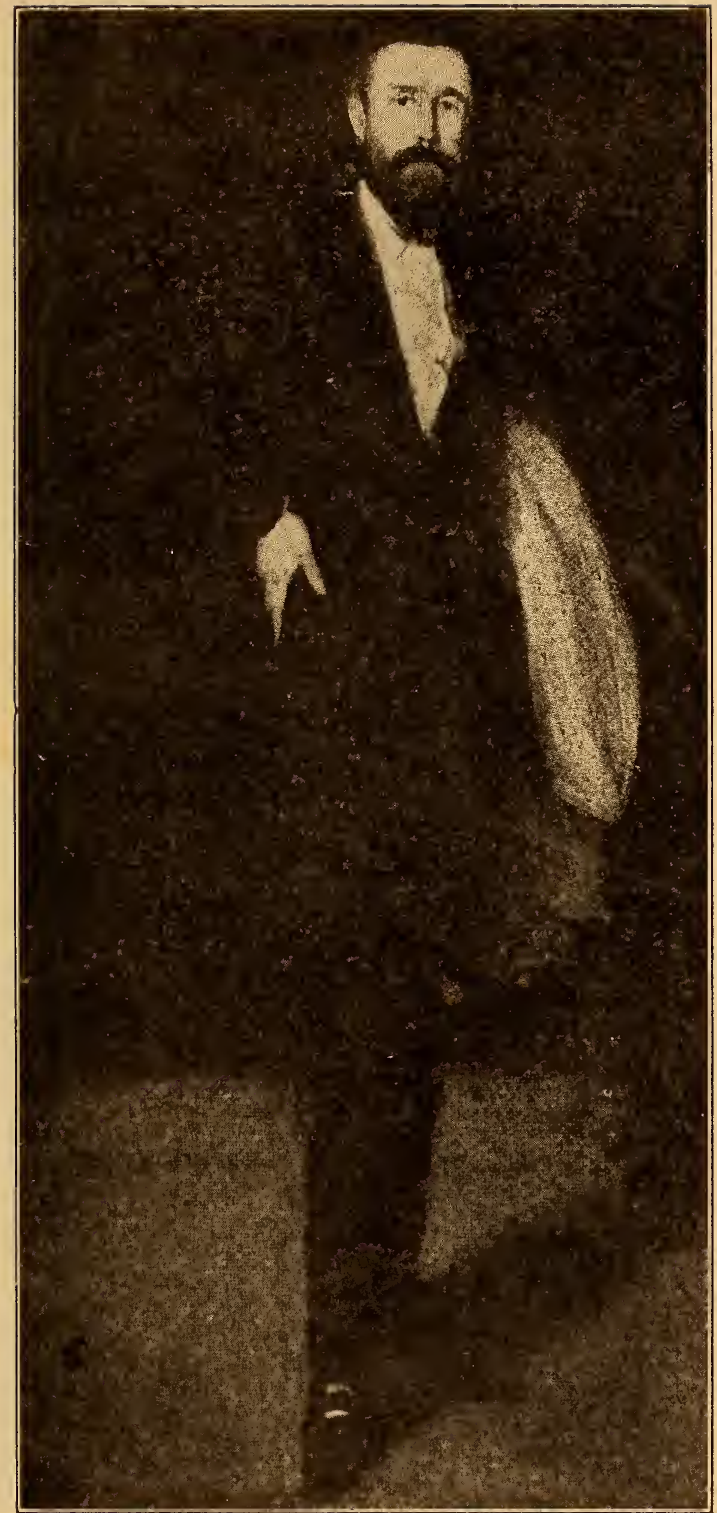

National Gallery, Washington ARRANGEMENT IN BLACK: F. R. LEYLAND. 

breakfasts, which Mr. Harper Pennington describes so amusingly: "They were always late in being served, outrageously delayed without apparent cause. It was no uncommon thing for us to wait an hour, or even two, for the eggs, fish, cutlets, and a sweet dish of which the meal consisted. A bottle of very ordinary white wine was our only drink. The whole thing, in fact, was an "arrangement" - just a colour scheme in yellow to match his "blue and white" porcelain and his "yellow and blue" dining room. The room itself was unique in its effective and independent style of decoration. It was entirely carried out after his own designs, even to the painting of the exterior. And the environment, the Thames, the old church of Chelsea with its square tower, the peculiar shaped bridge of Battersea, the lights of Cremorne in the distance, all furnished interesting pictorial topics and played an important part in the painter's mise en scène.

His neighbours added to the lustre of this period. In the same district at that time lived Rossetti, Swinburne, George Meredith and Carlyle, and Whistler was on friendly footing with all of them.

Exhibitions of his work were now a regular occurrence. In 1874 he held his first "one 
man's show" of thirteen paintings and fifty prints at number $48 \mathrm{Pall}$ Mall, London. In 1877 he arranged an exhibition in the Grosvenor Gallery. Among the exhibits were "The Falling Rocket" (Nocturne in black and gold) which brought about the Ruskin attacks, and consequently the famous libel suit, Whistler v. Ruskin. One can hardly imagine, to-day, why the picture should have created so much commotion; but it was a decided innovation at that time, an event in a way ushering in a new era of art. Now this particular style of representation has any number of disciples, and we have accepted it as one of the principal assertions of modern art.

Strange, that history always repeats itself. We should know by this time that our tastes and the tastes of time are not absolute, and that our sense of beauty is likely to be affected by circumstances to an extent which we cannot realize. There was a time, and not so long ago, when Gothic buildings were regarded by the man of culture much as dandelions are regarded by the gardener. For years the very name Nocturne was a reproach. It was supposed to be the product of idiosyncrasy and nonchalant audacity, the work of a decadent period in art, which, because it was decadent, could not be good, for everything that looked 
like a Whistler was regarded as a note of decadence. It was an argument in a circle, no doubt; but such arguments seem most convincing when once a prejudice exists in the art world. Only gradually did people begin to see more than cleverness in his products.

Oscar Wilde was a constant friend of Whistler's at this time. The friendship was still young and, for a while, the two were inseparable. The author of "Dorian Grey" spent hours in Whistler's studio, came repeatedly to the Sunday breakfasts, and presided at Whistler's private views. Whistler went out and about with him everywhere. But Whistler gradually came to feel that Wilde, in spite of his brilliancy and wit, lacked fundamental purpose. Wilde talked constantly about art, but, in the end, Whistler concluded that Wilde, like most modern authors, knew very little about it.

The days of the Renaissance, of versatility, of talent and appreciation seem to have passed. Whistler easily tired of his friends and, although this friendship had lasted for years, he finally dropped Wilde without much ado. A critic of "The London Times" has summed up the difference between the two in the following words:

"With a mind not a jot less keen than 
Whistler's, Oscar Wilde had none of the convictions, the high faith for which Whistler found it worth while to defy the crowd. Wilde had posed to attract the crowd. And the difference was this, that, while Whistler was a prophet who liked to play Pierrot, Wilde grew into Pierrot who liked to play the prophet."

Like most artists who have suddenly sprung into fame, Whistler had lived beyond his means. He was fond of comfort and elegance, and allowed himself the fulfilment of any whim as long as it granted him genuine pleasure, as "art and joy should go together."

The auction sale of the contents of his home in 1879, and the sale of his paintings at Sotheby's in February, 1880, were perhaps not entirely caused by financial difficulties. They may have been prompted in an equal degree by a desire to make a change and break the routine of the studio life. He told, however, to his friends in his inimitable way how the sheriff's officer called upon him with a writ, and the last bottle of champagne was brought out of the cellar for that worthy's delectation. In Venice, where he went in September, 1879, he seems to have been in straitened circumstances for quite a while. He lived in modest quarters and dined in cheap, dingy places. 
These were his "polenta and macaroni days," and, in a way, a repetition of his Paris student's life, only much harder to bear as he was older (forty-five) and used to luxury.

No matter what his reason may have been for breaking up his bachelor establishment it was the second turning point in his career.

Painting did not play quite as important a part in Whistler's life after his Venetian sojourn. He still painted a number of portraits, among them the "Sarasate" and "Comte Montesquiou," but he was more active as an etcher, lithographer, pamphleteer, lecturer and teacher. Orders were scarce at all times. The only regular portrait orders he had in the first half of the eighties were those of Lady Archibald Campbell, wife of the Duke of Argyll; and of Lady Meux, who liked her first portrait, in a black evening gown with a white opera cloak against a black background, so well that she had herself painted three times in succession. Whistler's sense of beauty was a strong feature in his work. Maybe it was not the sense of beauty an Englishman would like. He looked for a pictorial aspect, rather than the "lady" in his sitter; and in England the "lady" is the thing to secure in a portrait of a woman.

He returned to London in $\mathbf{1 8 8 0}$, but stayed 
only a short while. During the next ten years he had no permanent home; like a nomad he flitted from city to city, from studio to studio through England, France and Belgium. Finally he found some sort of a resting place in the rue du Bac 110, for many years his Paris home. It was a two-story house with a garden enclosed by a wall, as secluded a spot as one could find in the gay and noisy city. He was always fond of gardens of flowers. "In the roses of his garden he buried his sorrows," one of his most talented pupils, E. H. Wuerpel, tells us, in his little brochure "My Friend Whistler."

In the meanwhile his London Exhibitions became more and more numerous. During the next fifteen years the following eight exhibitions are on record.

1881 - Jan. - An exhibition of fifty-three pastels at the Fine Art Society in Bond St., London.

1883 - Feb. - Fifty-one etchings and dry points exhibited in Bond St. Gallery, London. 1884 - May - Harmonies - Notes Nocturnes - shown at the Dowdswell Gallery, London. At the same time an exhibition took place in Paris and Dublin. They were arranged according to his own idea of exhibiting. 


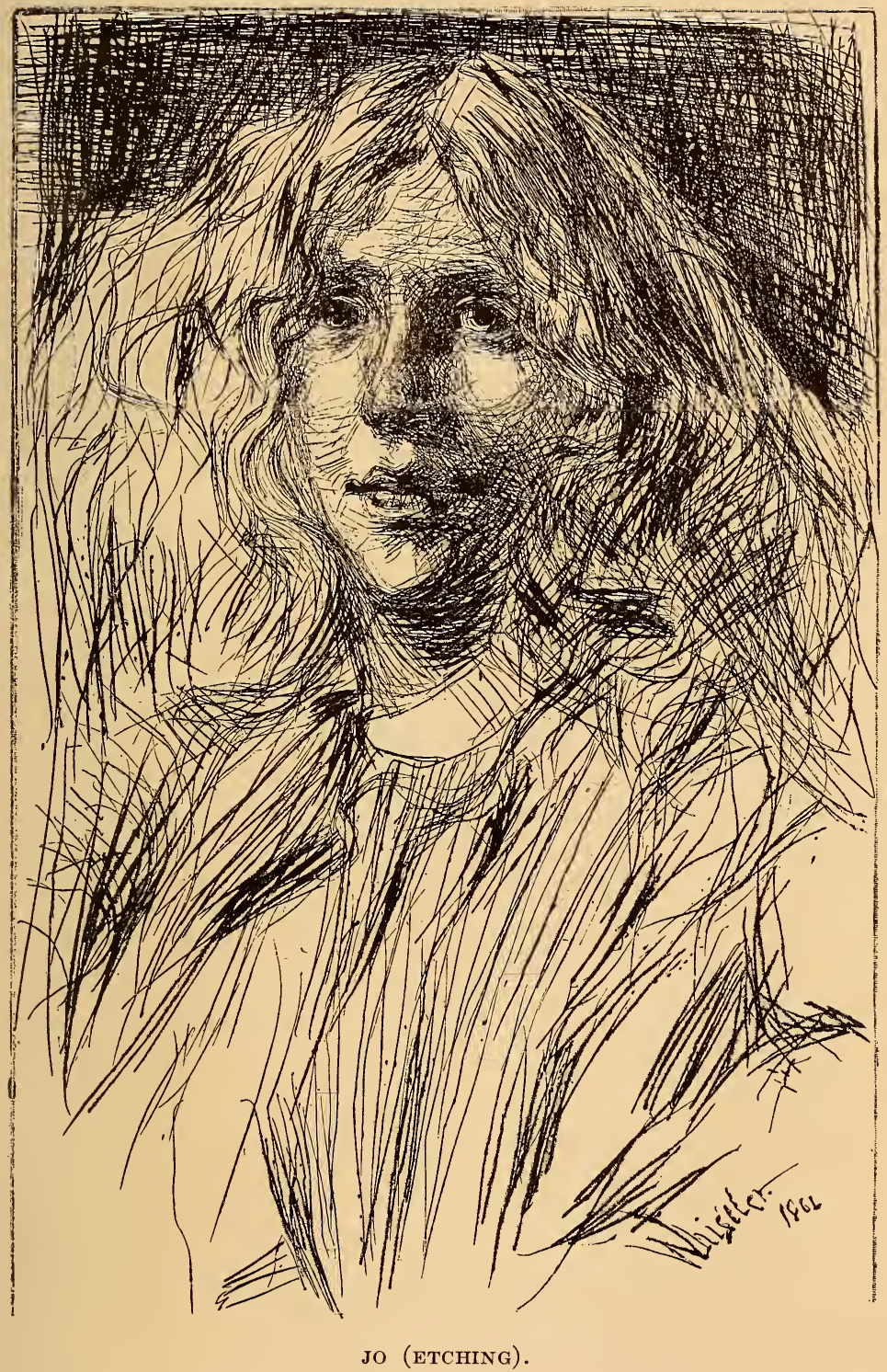



1884 - Nov. - Twenty-five works sent to the exhibition of the Dublin Sketching Club.

1886 - May - A second series of Notes Harmonies - Nocturnes shown at the Dowdswell Gallery.

1889 - The most representative exhibition of his works, since that of 1874, at the College for Working Women, Queen Sq., London.

1892 - Mar. - An exhibition of forty-four nocturnes, marines and chevalet pieces for which Whistler prepared the catalogue. At the Goupil Galleries, Bond Street, London.

1895 - Dec. - Exhibitions of seventy lithographs, London.

In the years following his death, as is usually the case, 1904-05, occurred the most important assemblage of his works - the memorial exhibition of Glasgow, Boston, Paris and London.

Of special interest are Whistler's first American exhibits. At the first exhibition of the Society of American Artists at the Kurtz Gallery, New York, 1878, he was represented by a "Coast of Brittany." In the autumn of 1881 at the Pennsylvania Academy of Fine Arts he exhibited the portrait of his mother, which was also seen the following spring at the Society of American Artists in New York. 
Sheridan Ford once asked him why he did not exhibit more frequently in America. Whistler answered: "I don't know, they will not allow me to take them across the ocean. You see, I don't own my pictures. I sold most of them long ago to people who think more of them than they do of me. I wrote and asked for two or three of them to take over, and the answers I received were to the effect that I could have them to exhibit here, but not to exhibit in America. Why? Because the owners are afraid of the ocean. I said I would insure the pictures, at which of course they laughed. I may go and I may not. A good many people in America don't like me, and I am not there to fight them as I can fight my enemies here. I don't mind having enemies where I can get at them. I like the pleasure of whipping them; but these fellows in America have it all their own way. There is no record, and I am at a constant disadvantage."

In 1884 he was elected President of the Royal Society of British Artists, but soon quarrelled with the old-fashioned element among its members, and the whole affair degenerated into one of those disputes upon which such copious light has been shed in "The Gentle Art of Making Enemies."

The enforcement of the Whistlerian policy 
of elimination and arrangement brought disaster upon the Society. The annual sales fell from $£ 8,000$ in 1885 to under 1,000 in 1888 . It was time for the ideal exhibitor and manager of mise en scènes to retire. And so he did, if not accompanied by a cavalcade of buglers blowing a blast with, at least, as much noise and controversy as he could conjure up in these art-forsaken and colourless days.

It is not until towards the close of his life, in 1898, that we find him again at the head of an artistic corporation, when the International Society was proud to acknowledge his leadership. In 1880 Whistler made his début in Germany at the International Art Exhibition of Munich. The result was not a flattering one. The jury officiating on that occasion established a peculiar claim to the affectionate recollection of posterity by awarding a Second Class medal to the "Portrait of the Artist's Mother," now in the Luxembourg. Of course a jury has perfect rights to make awards as it pleases as long as the verdict is a competent and impartial one, but Whistler by this time was too well-known, and one can hardly blame him that he wrote the following sarcastic but unusually dignified letter to the Secretary of the Central Committee. 
"SIR: I beg to acknowledge the receipt of your letter, officially informing me that the committee awards me a second class gold medal. Pray convey my sentiments of tempered and respectable joy to the gentlemen of the committee, and my complete appreciation of the second-hand compliment paid me.

\author{
"And I have, Sir, \\ "The honour to be \\ "Your most humble obedient servant, \\ "J. McNeIll Whistler."
}

After 1895 Whistler ceased to hold exhibitions. The death of his wife brought about a long silence, and little was heard of Whistler. He had laid aside his jester's bells and cap and ceased pamphleteering and posing in public. He had become a kind of recognized institution in the art world, occupying a place apart from the masses of his contemporaries. Men of very dissimilar esthetic convictions agreed in regarding him as a painter of exceptional ability, and he had a solid and appreciative following.

We in America wondered what had become of him. Occasionally a newspaper notice informed us that he had taken up teaching, or false reports crossed the ocean that he had be- 
come a symbolist. He himself was inactive, as far as the public was concerned.

I suppose he was at last tired of notoriety and the cares of public life. He had played his part and had played it well. Intimate friends tell us that he worked as hard as ever. He still had many problems to solve, if for nobody else but himself, and was satisfied that he could afford to devote his time to them. Financially he was fairly well situated; but he spent money extravagantly, and the two residences and various studios he kept up in Paris and London proved at all times a heavy drain on his income, which was derived entirely from his art products. He left about ten thousand pounds, a rather small sum, considering the prices he received for some of his paintings.

His school in the Passage Stanislaw, opposite Carolus Duran's home, was neither a necessity nor a particular pleasure to him. $\mathrm{He}$ opened it for the sole benefit of one of his favourite models, Mme. Carmen Rossi, who, as a child, had posed for the painter. She received the entire profits and it is said that during the three years that the school existed she made enough to retire in comfort. The school was opened in the autumn of 1898 and closed in 1901 . He was too impatient to be a 
good teacher; he simply came there and painted and the pupils saw him paint and learned what they could, just as did the apprentices of the Old Masters. He taught solely the science of painting, neither colour nor composition. He had an abhorrence of talking art, and one of the anecdotes he liked to relate was that he had known Rossetti for years and " had talked art many, many times but painting only once."

He even refused to discuss technicalities. There was no talk of pigments, mediums, varnish or methods of applying them. He worked with his pupils, that was all. Like the apprentices of old they had to pick up their knowledge themselves, and if he found something that he liked his usual praise consisted of "Go right on," or "Continuez, continuez." On the wall was tacked his second series of propositions which endorsed his constant advice to pupils: "If you possess superior faculties, so much the better, allons, develop them; but should you lack them, so much the worse, for despite all efforts you will never produce anything of interest." Good common sense, but, after all, a slight return for the tuition fee. It should have induced most pupils to pack up their paint boxes and return home.

As Leon Dabo, in his lecture on "Whistler's 
Technique" at the Metropolitan Museum of Art, has so well observed: "Nothing is more absurd than the notion, so widely promulgated by elderly maiden ladies who misspend their energies writing about paintings and painters from Cimabue to Whistler, that a work of art is produced as the logical result of an apprenticeship served in an art school. There probably is much juxtaposition of this belief - we all know the painters whose only reason for lowering intensely blue sky is because it is too blue; the painters who labour, heaping up chunks of paint until it looks ' right;' but with Whistler a canvas advanced in an entirely different manner. He knew scientifically that he could use only so much of a given tone if he wished to produce colour, and he knew what other tone to place in juxtaposition, what parts of the canvas must hold the spectator's eye, in varying degrees of interest, in order to obtain the effect he desired to give and its use in the butterfly, the exact spot of a sail on the ocean, a light on the horizon, all these, to many insignificant objects and spots, nevertheless do their work, either to re-vivify an otherwise large surface or to hold the eye momentarily interested, until the ambience was obtained. And this science - the effect of line and colour on the eye, - is prac- 
tically unknown to painters, is untaught in our art schools. This mastery over his means and material Whistler possessed in a higher degree than any other modern painter."

In 1902 he once more took a house in London and selected Cheyne Walk, an old mansion covered with ivy, near the Thames in the Chelsea district, where he had spent so many years during the beginning of his career. Friends could not imagine why he came back from Paris to London, as he disliked the place, its climate and its art. They simply forgot that he was a lover of atmospheric effects, and that London fogs and the Thames were, after all, nearest to his heart. In the summer of 1902 he contemplated a short trip to Holland in the company of Mr. Ch. W. Freer, but was taken sick in Flushing. After consulting some doctors in The Hague, he recovered sufficiently to return to London and set to work, but only one year in the old haunts was granted him.

He had just entered upon his seventieth year when he died suddenly on July 17, 1903. He suffered from some internal complaint, the exact nature of which is unknown. He had felt ill for several days, but on the seventeenth his condition had so improved that he ordered a cab for a drive. On leaving the house he was seized with a fit, but recovered; a short while 


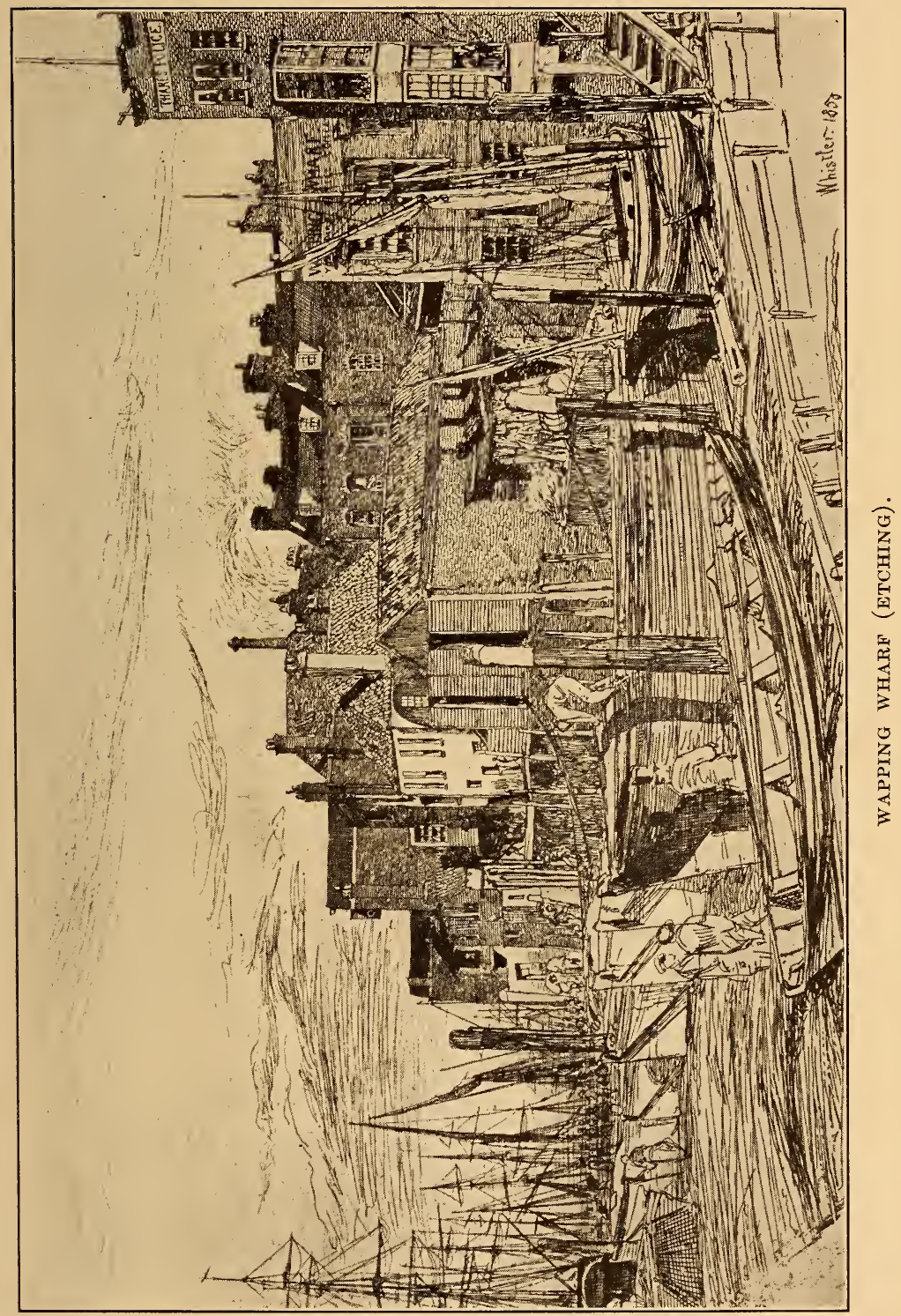



later he had another spasm, which killed him. $\mathrm{He}$ was interred (on the 22nd) in the family burial plot in the churchyard of the old church at Chelsea (which his mother had regularly attended), near the grave of Hogarth. The coffin, covered with purple pall, was carried to the church followed by the honorary pallbearers and relatives on foot. The pall-bearers were: Sir James Guthrie (president of the Royal Scottish Academy); Charles W. Freer, George W. Vanderbilt, Edwin A. Abbey, John Lavery (of the R. S. Academy) and the art critic, Theodore Duret; all personal friends of Whistler's.

The relatives present included the Misses Philip and F. L. Philip, Mr. and Mrs. Cecil Lawson, Mr. and Mrs. Charles Whibley and Edwin W. Godwin. Although no announcement of the funeral was made in London papers many distinguished friends and acquaintances crowded the church. Beautiful wreaths were sent by Vanderbilt, Lawrence, Alma Tadema and various federations and societies. Those present were: George W. Vanderbilt, Mr. Joseph Pennell, Rev. H. C. Leserve of Boston, Johnson Sturges, R. F. Knoedler and I. M. B. MacNary of New York City; M. Dumont of the International Society of Painters; Marcus Bourne Huish, 
editor of the "Art Journal;" Thomas Armstrong; and Alfred East (A. R. A.).

When a reporter called at the house July 18th he was informed that the artist had left stringent instructions that no information whatever regarding his illness or death should be given either to his friends or the newspapers. $\mathrm{He}$ remained true to his eccentricities, or rather to his peculiar personality. Even in his exit from this life to the thrones of glory beyond, he endeavoured to make it as odd and picturesque as possible. He played his part to the last. And it was one of the noblest parts ever played by man. 


\section{CHAPTER III}

\section{THE BUTTERFLY}

The famous butterfly monogram, originally a decorative combination of the letters "J. M. W.," which evolved into a decorative design of a butterfly, enclosed in a circle, as it appeared in his "Sarasate" and "Carlyle," and, frequently, a mere stencil-like silhouette as seen in his correspondence, began to appear in Whistler's pictures in the late sixties. The "Symphony in Gray and Green - The Ocean" (painted in 1866) was probably the first important canvas in which it was introduced. In his earlier pictures he had made use of an ordinary written signature as most painters use. It is strange that it took an artist of Whistler's sensitiveness so long to realize the incongruities of these crude calligraphic displays. They disfigure many a good picture and smack of the materialism of this age. Every picture should have a signature, if for no other reason than to prove the authenticity at some future time. But surely it can 
be treated with more discretion than it is to-day. The Old Masters frequently handled it with ingenuity and some degree of modesty. It was the Japanese artist who gave it a decorative significance. The red cartouches of Hiroshige are known to every print collector. $\mathrm{He}$ considered it a part of the picture, a colour note or vehicle of balance in an empty space, as important a detail of composition as any other.

Whistler treated his monogram in the same conscientious and picturesque fashion. $\mathrm{He}$ used it with preference in his symphonies, nocturnes and large portraits, but, at times, also in white, as on a rail post in the lower right corner of his "Bognor." He handled it with more than ordinary reverence, as everything that pertained to the exploiting of his own personality. He often introduced it at the first painting to judge the effect, and, of course, he wiped or scraped it out over and over again until he procured the desired effect. He continually made slight changes in the design, he toyed with it as with some curio, elaborated it in many ways, and, eventually, even bestowed a sting upon the insect, as it appears in his "Gentle Art of Making Enemies."

The butterfly teaches a lesson. It proves that an artist can be self-assertive, arrogant 
and yet refined. Whistler thus introduced a method of picture signing that should be generally adopted. Every artist should have his own monogram, and use it with discretion.

But it has even a deeper significance in Whistler's life. It is in a way a symbol of his evolution as a painter. As we study his work we find that the butterfly monogram does not appear before Whistler freed himself from foreign influences, and invented an individual and independent style of his own. The butterfly may well stand for the full awakening and realization of his own faculties. Did he not say himself:

"In the pale citron wing of the butterfly, with its dainty spots of orange, he saw the stately halls of fair gold, with their slender saffron pillars, and was taught how the delicate drawing high upon the walls should be traced in slender tones of orpiment and repeated by the base in notes of graver hue."

Like all painters Whistler had to learn his trade, and then find his peculiar way of expression. It took him well nigh a quarter of a century. He entered the studio of Gleyre in the summer of 1855 as a young man of twentyone, and was nearly forty-seven when he had finished the "Portrait of the Artist's Mother" and had painted a few nocturnes. All his 
earlier pictures remind us of some other master. "The Music Room" recalls Stevens, "The Blue Wave: Biarritz" the forceful style of Courbet, and "The White Symphony" even the light manner of Alma Tadema.

Charles Gleyre was an excellent draughtsman of the Ingres school, but all he could teach his pupils was to draw. That he had once been capable of some finer appreciation of colour and atmosphere, students of art may notice in his "Evening," painted in 1843, but he became, like so many other painters of this period, the victim of the academic style. Outline drawing reigned supreme, there was room for nothing else, and it was surely not a congenial environment for young Whistler, who, even at that time, differed with the prevalent ideas of art. Drawing, however, is one of the most important factors of the technique of painting. Velasquez even thought it was the most important one, and Whistler, with the peculiar tendency of his art, was, no doubt, fortunate that he reached Paris while draughtsmanship was still honoured and not neglected, as in the later days of the impressionists. A student in Paris either becomes an enthusiastic worker from the nude, making one study after the other, like all those Julian and Colarossi 
pupils - or he gets so imbued with the art atmosphere that he sets about on conquests of his own, and the city of Seine, with its museums, monuments, artists, population, pleasures and sights is just the right place for "free lance" education. Whistler chose the latter way.

The canvases of this period show strong influences of Stevens and Courbet. He must have been enamoured with the style of that great painter of woman, as he was undoubtedly with the rude sincerity of Courbet. If any man could paint at that time it was Courbet. $\mathrm{He}$ was the simplifier of planes and values, who advocated frankness and freedom of expression, and detached painting from all the absurdities and abstractions of the classic and romantic periods. From him Whistler learned to put on his pigments in a bold, vigorous way. He was never fond of brushwork, but at that time he liked to pile it on in a flat and solid manner. Only gradually his brushwork became thinner and thinner, invisible and almost untraceable, carrying out his maxim: "A picture is finished when all traces of means used to bring about the end have disappeared." As is the case with all great paintings, one must forget all about technique.

From Stevens he learned, as he often said 
in later years, all that could be learned from him. I believe that the influence was subtler and more spiritual, and one that lasted all his life. Stevens was for him what the chart from which we learn history in school days remains for us. We can never forget it and entirely get away from it. In the beginning, of course, it was a technical preference. Like Stevens, he used precise outlines, a profusion of details and yet with all a poetic atmosphere that is produced principally by a beautiful juxtaposition of colour values. Even to-day few of Whistler's earlier canvases have more admirers than the "Harmony in Green and Rose," perhaps better known as "The Music Room" (in the possession of Frank J. Hecker). It was painted in 1860, in the London home of Haden, the painter-etcher. This picture was first known as "The Morning Call." In the corner of the room a mirror reflects the profile of a woman, who is not represented in the picture. This is a portrait of Lady Seymour Haden, Whistler's stepsister, with whom he was lodging at the time. In front of the window hang a pair of white curtains with a green and red flower pattern. A young woman (Miss Booth, a relative of the Hadens) in a black riding habit, which she holds up with her gloved hand, stands on the dark red car- 


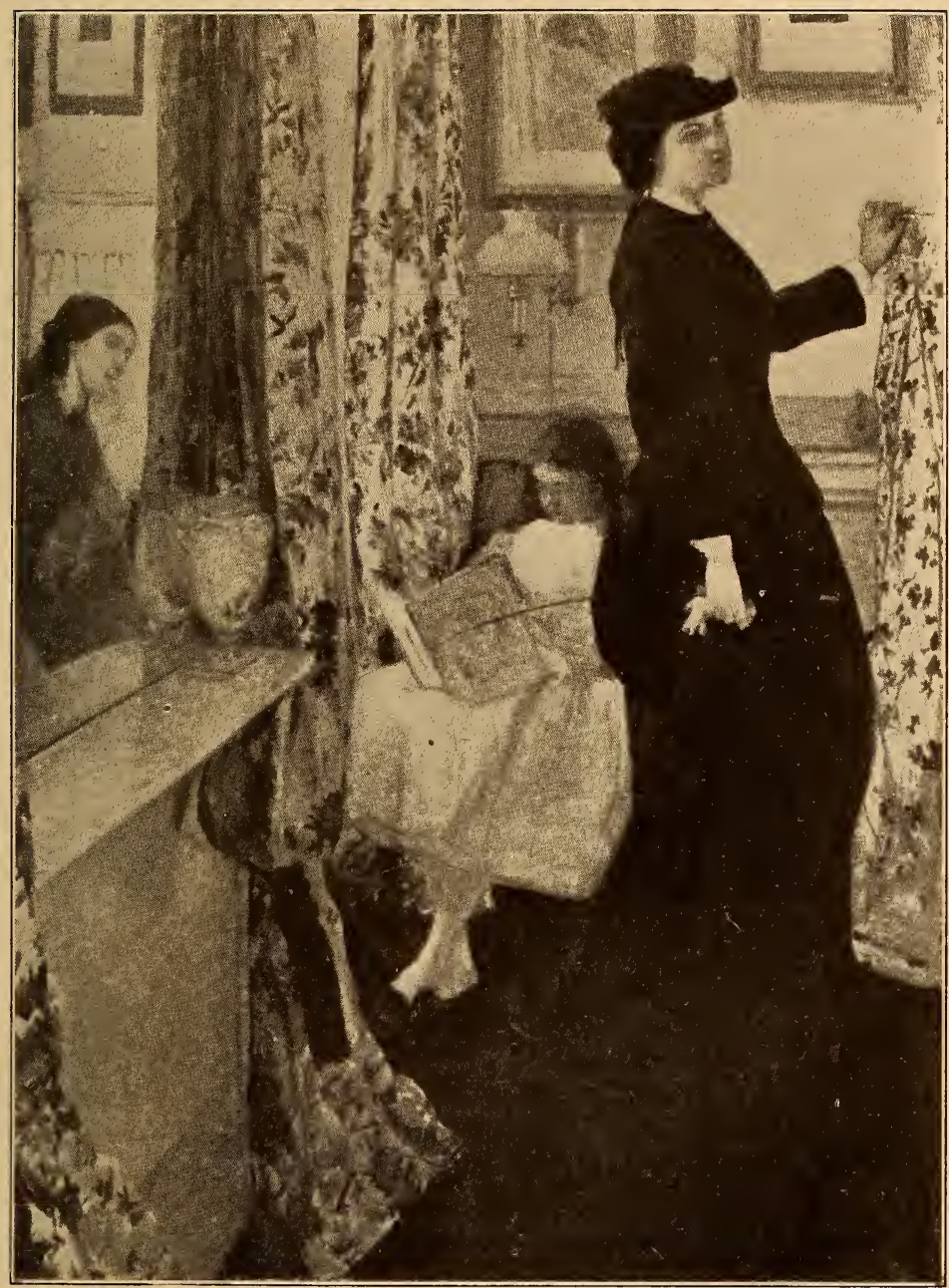

Owned by Frank J. Hecker

HARMONY IN GREEN AND ROSE: THE MUSIC ROOM. 

pet. In the background sits a little girl reading.

Another more exotic influence became palpable in his work soon after, and exercised an almost despotic control for several years. At the Paris Exposition Universelle of 1863 Whistler became acquainted, for the first time, with Japanese art. The Parisian artists, particularly the set with which Whistler was acquainted, got colour mad. The suggestiveness of Oriental composition, which accentuates detail here and neglects it there; the peculiar space arrangement and the decorative treatment of detail, captivated all modern spirit.

Edmond and Jules de Goncourt, the esthetes of the Empire, and the forerunners of the Japanese enthusiasts, and specialists like Cernuschi, Regamey, Guimet, and Bing became the spokesmen for Japanese bibelots. Paris was deluged with little art objects fashioned out of bronze, porcelain, cloisonne, jade, ivory, wood and metal. Everybody started a collection, and became a member of the "Societé du Jinglar," with annual meetings at Sèvres, which was fanatically devoted to the worship and exploitation of Eastern art.

The harmonious arrangement of the Japanese colour prints in particular fascinated the cognoscenti. The application of colour in 
Japanese art is somewhat different to ours. It is more primitive, and based on the decorative principle of simultaneous contrast. It deals solely with flat tints with occasional gradations on the outer edges, and vibration is produced by the simple method of letting the paper, or silk, shine through the pigment. If Japanese colouring does not directly recall the polychromic designs of primitive people, of pottery decorations, wall designs, carpets and mats, Scandinavian wood ornamentation, etc., the reason is entirely to be found in its refinement and finish. It has the same origin; a totem pole is the beginning, and a Japanese print about the end of the development.

True enough, coloured prints were classified as vulgar art. They were considered ordinary pictorial commodities of no more importance to the natives than coloured supplements to our Sunday readers. But they were of such exquisite finish that we wonderingly ask ourselves if the nobler branches of art in this country really reached a higher standard of perfection. It is hardly possible. It was rather their application than their art value which offended the nobility. Many of the most cherished prints of Kiyonaga, Sharaku, Shunsho, and Outomaro, depicting teahouse scenes, actors, wrestlers and ladies of the Yoshiwara, 
were drawn for no other purpose than to serve as souvenir cards and advertisements.

The colour appreciation of the Japanese clerk, labourer and peasant must have been developed to an exceptional degree, if these designs, that were so cheap that everybody bought them as we do newspapers, could arouse nothing but ordinary appreciation and matter-of-fact comment.

The Japanese used colours in combinations that seem strange and unusual to us. They did not seem to care about any complementary laws, but introduced yellow with pink, purple with green, brown with red without the slightest hesitation. This may be explained by the restraint of their palette. Their old hand-made colours are all keyed in middle tints; they did not lack decision or strength, but they were never loud or vehement. Thus arrangements were possible that would look crude with the use of Western colours. Cheret's and Toulouse Lautrec's posters, even when of threesheet dimensions and seen in open air, seldom expressed more than contrast and animation. They worked on the principle of the Japanese colour print, but in a very crude and superficial fashion. They wished to startle, not to please.

If colour is seen in flat tint patches it pro- 
duces a more vivid image on the retina than a pictorial representation of mixed pigments, as flat tints are more favourable to the brilliancy of colour. Each separate soft tint creates a complementary image, and the eye would be easily fatigued if the colours were strong. In the Japanese colour print they are softened and blended together not so much by the skilful and harmonious juxtaposition, as by the suavity of the medium, the introduction of neutral tints, the mellow white foundation of the paper, and the arrangement of shapes encased in precise lines.

The European painter had a different idea. Although recognizing the supremacy of colour, he took visual appearances as they were and actually appeared in life as guiding models for his representations. Colour became submerged in other qualities almost equally important, as those of line, perspective, chiaroscura, relief drawing and minute observation. The Eastern artist applied colour for colour's sake, and kept all other elements, notably those of line, feeling, shape and space arrangement independent - not independent as far as the tonality of the final effect was concerned, but independent in their function as vehicles of expression. They were never diffused in the same way as in an Old Master. 


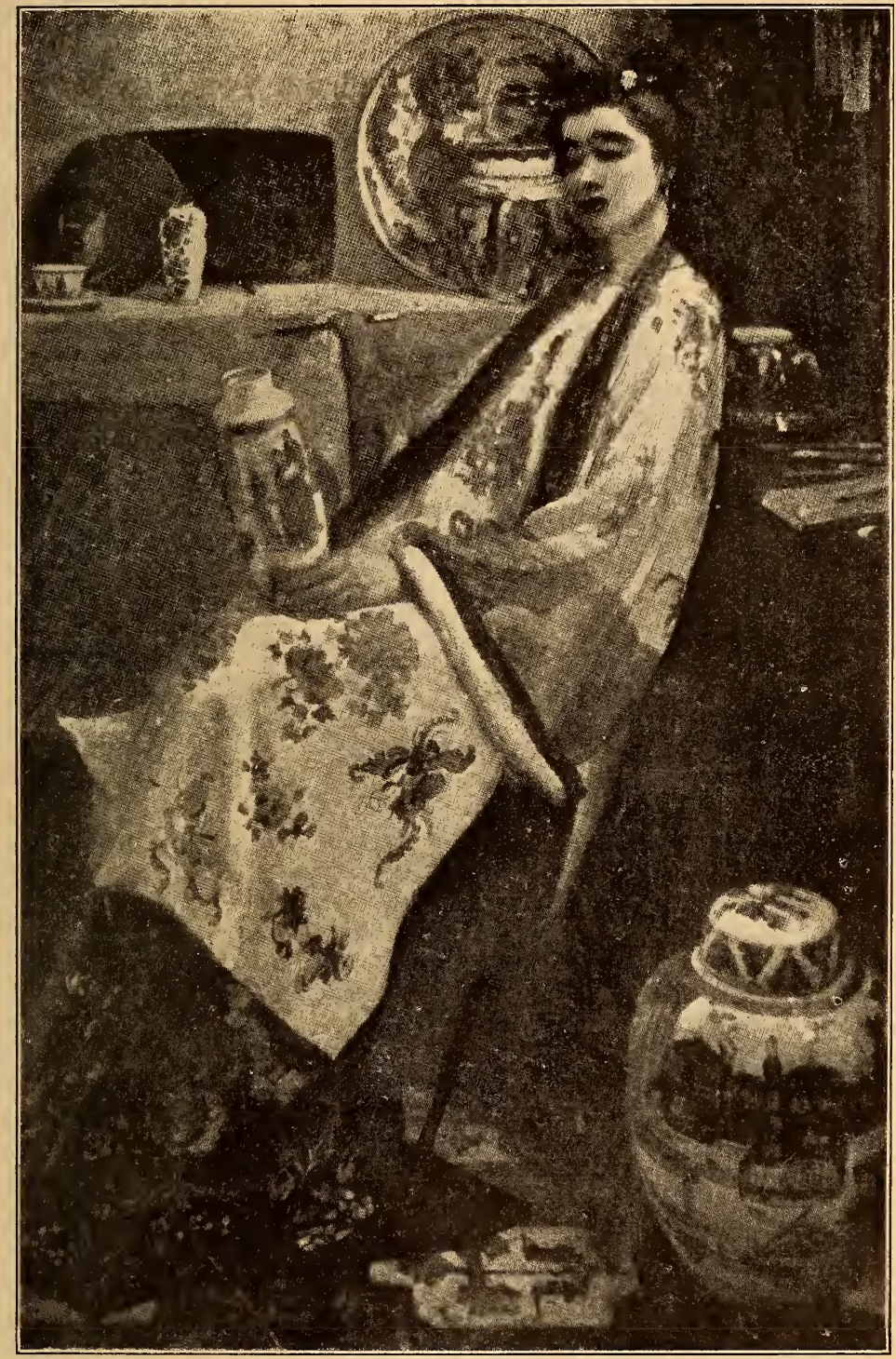

Owned by John G. Johnson

LANGE LEIZEN OF THE SIX MARKS: PURPLE AND ROSE. 

Each line, shape and colour had to tell its own story, while in Western art composition, colour and idea often became inseparable by the application of the blurred outline.

Whistler, at this stage of his development, was interested simply in recreating Japanese colour arrangements, to paint local values in such a way that they would reflect the beauty, contrast and variety of an Outamaro print. The pictures of this period remind one of that capricious Chinese princess, of whom Heinrich Heine speaks, whose quaint and solitary pleasure consisted of tearing costly silks into tatters, to scatter the rags to the winds and to watch them flutter like rose, blue and yellow butterflies to the lily ponds below.

Already in his "Woman in White" Whistler had shown some preferences for colour, but not until after he had taken his first house in London, when his mother came to live with him, did he show those peculiar outbursts of colour that were a direct outcome of the study of Japanese prints. In later years it was all tone, but in the years 1863-66, it was all colour, with a preference for white. The principal pictures of this period were "Lange Leizen of the Six Marks: In purple and rose" (in the possession of John G. Johnson); "The Little White Girl" (owned by Arthur Studd), 
"The Golden Screen," "The Princess of the Porcelain Land," and "The Balcony: Variations of Flesh Colour" (owned by Charles W. Freer) and "The White Symphony" (owned by John G. Whittemore).

Whistler clothed his English models in Eastern dress, and reproduced the beautiful colours with Japanese detail. He was among the first to appreciate the beauty of Chinese porcelain, of which he owned many choice pieces. In his "Lange Leizen" is shown a young woman in a Japanese costume, seated and holding with her left hand on her lap a blue and white vase of the shape known in Holland as the "Lange Leizen of the Six Marks" (referring to the potter's mark on the bottom of the vase). Her right hand, covered by the sleeve of the kimono, is raised and holds a brush. Her skirt is black with a delicate design in colours. The kimono is cream white, decorated with bright flowers and lined with rose colours. Around her hair, which falls over her shoulders, is tied a black scarf. On the floor are several blue and white vases and an Oriental carpet. To the right is a red covered table, and behind the figure is a chest. The painting is signed "Whistler, 1864," in the upper right-hand corner. The frame was designed by Whistler himself and decorated 


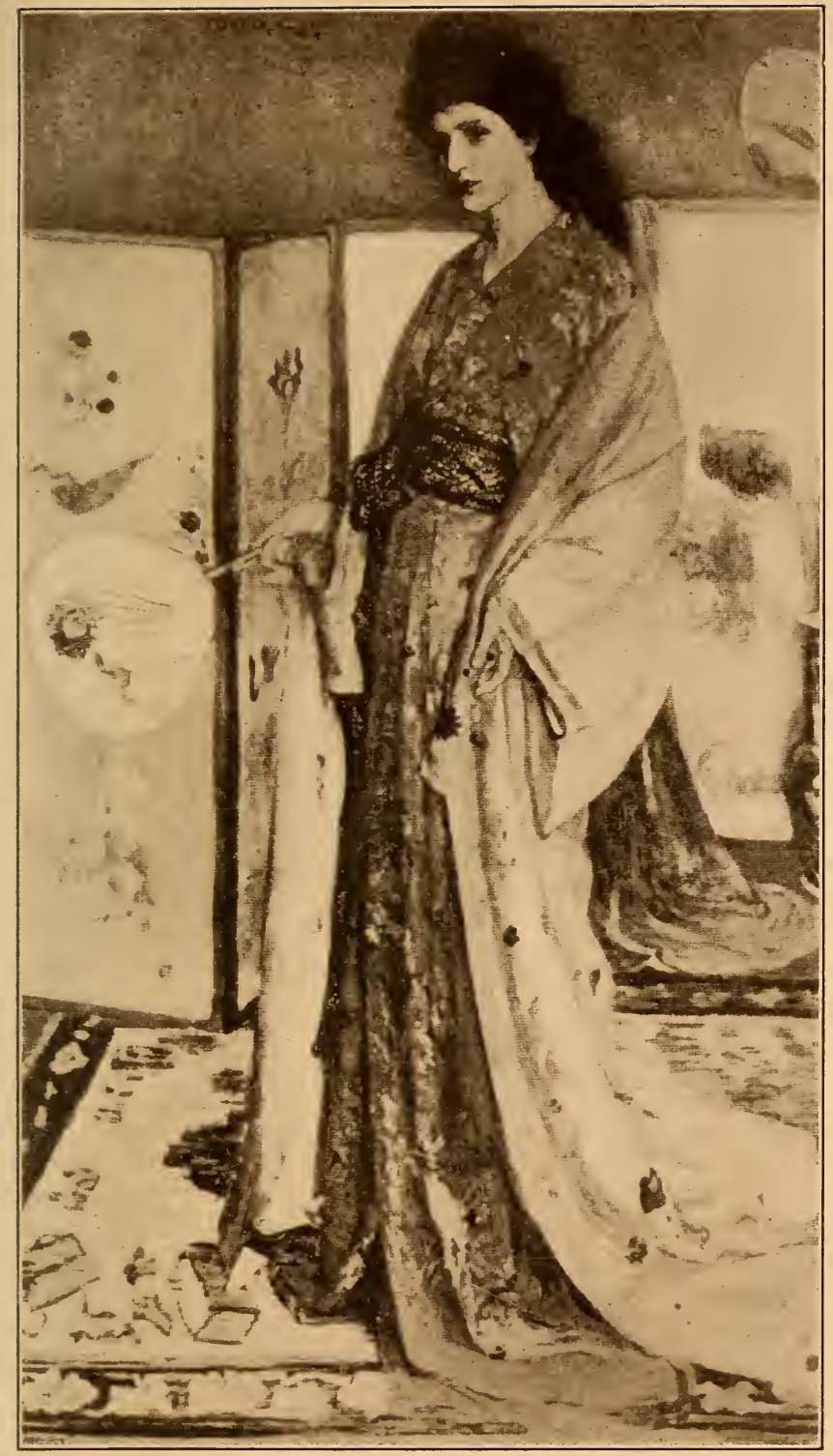

National Gallery, Washington

THE PRINCESS OF THE PORCELAIN LAND. 

with Chinese fret and six marks. It was shown in the Royal Academy of 1864 .

Another picture of this period is the "Golden Screen." A young woman in Japanese costume is seated on a brown rug, her head seen in profile, as she examines a Japanese print. She wears a purple kimono decorated with multicoloured flowers and bordered with a vermilion scarf, and a green obi tied around her waist; her outer kimono is white with a red flowered design. To the left is a tea box, some roses and a white vase with pansies. Hiroshige prints are scattered over the floor. The background consists of a folding screen with Japanese houses and figures, painted on a gold ground. These two pictures are far from being satisfactory. The composition is restless, the colours do not harmonize, and the figure is one of that peculiar nightmarish type which some artists affect; a being belonging to that peculiar class of humanity who wear slouch drapery instead of tailormade costumes, and carry crystal balls, urns and sunflowers as an æsthetic amusement, I suppose, about their person.

The model for both these pictures was Joanna Heffernan, an Irish girl, neither particularly handsome nor well educated; but she was a good model, who adapted herself easily 
to a painter's idea, and her native wit and willingness to learn atoned for any lack of knowledge. She generally read while she was posing for Whistler, and as she talked with his friends; posed for other artists and visited picture exhibitions, she played quite an important part in the painter's life during his early years in London. She went to Paris in the winter of 1861-2 to pose for "The Woman in White," in his studio on the boulevard des Battignoles. He painted her in a number of other pictures, notably as "Jo" and "The Little W.hite Girl." Although different in each picture, now young, now more mature, in one case a lady and in another a buxom girl, she is really beautiful in none, though always attractive. He probably merely used her as a suggestion. He liked to have her in his studio even when he did not paint her form or features. There is also a dry point of "Jo," dated 1861, which shows her with streaming hair, which is probably the nearest approach to a likeness. It is a beautiful bit of drawing and interesting as a space arrangement. It shows how a head can almost fill the entire space of a picture without becoming obtrusive or looking too large. The line work is excellent in its purity of design and apparent carelessness. 


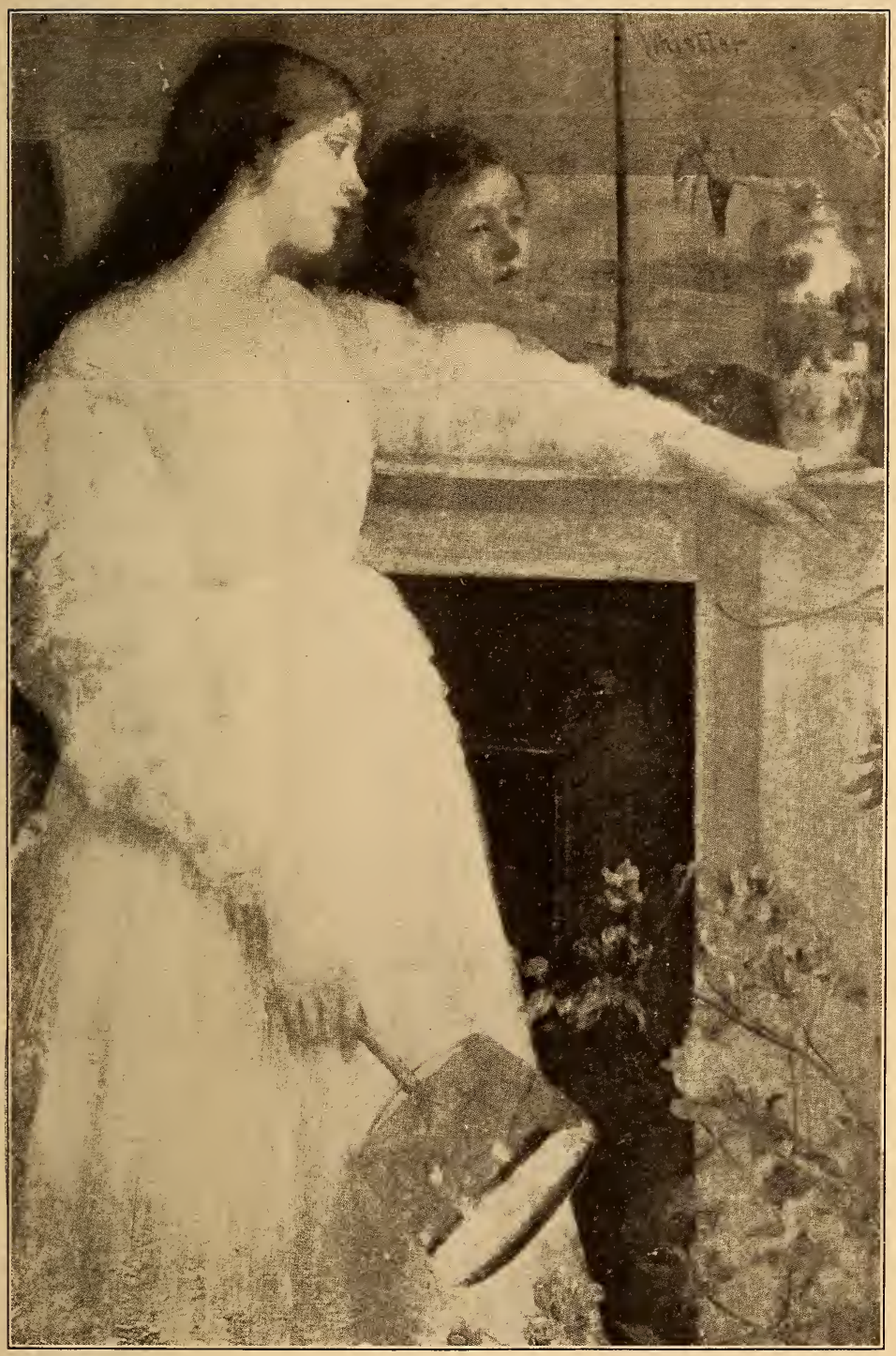

Owned by Arthur Studd

SYMPHONY IN WHITE, II: THE LITTLE WHITE GIRL. 

A change of method is noticeable in "The Little White Girl," the colour scheme of which is exquisite. The white dress of the young girl, in profile, with loosened hair, leaning against a mantelpiece, and her reflection in the glass, are accentuated in a beautiful manner by the brilliant colour notes of a red lacquer box, a blue and white vase, a fan with a Hiroshige-like design and a decorative arrangement of pink and purple azaleas. The painting is thinner and there is greater repose in the composition. Swinburne saw the picture before it was sent up to the Royal Academy in 1865 , and expressed his admiration by writing "Before the Mirror. Verses under a Picture:"

"Come snow, come wind or thunder, High up in the air

I watch my face and wonder

At my bright hair.

Naught else exalts or grieves

The rose at heart that heaves

With love of our own leaves, and lips that pair.

"I cannot tell what pleasures

Or what pains were,

What pale new loves and treasures

New Years will bear,

What beam will fall, what shower

With grief or joy for dower.

But one thing knows the flower, the flower is fair." 
"La Princesse du Pays de la Porcelaine" (Whistler apparently was fond of using elaborate titles) is perhaps his finest work in vivid colouring. The colour differentiations are. well placed, but the canvas, after all, looks too much like a huge Japanese print, painted in the Western style, which represents objects round and in relief, and not merely in flat tints. The placing of the screen with the face looming above it is as peculiar as it is attractive, but it is an arrangement that is strictly Japanese in character. Whistler began with painting detail, and only gradually learned to see life in a broader and more mysterious way. It is a portrait of Miss Christie Spartali, a real Rossetti type, daughter of the Consul-General for Greece in London in 1863. Her father did not like it; but Rossetti did, and sold it from his own studio to help Whistler along. Later it came into the possession of F. R. Leyland, and was used to decorate the "Peacock Room." It was first exhibited at the Paris Salon of 1865. It is really a combination of Rossetti and Outomaro, with a slight flavour of Whistler's individuality.

"On the Balcony" (exhibited first in 1866) of the Freer collection is a peculiar combination of models masquerading in kimonos and a background of English river scenery. He 


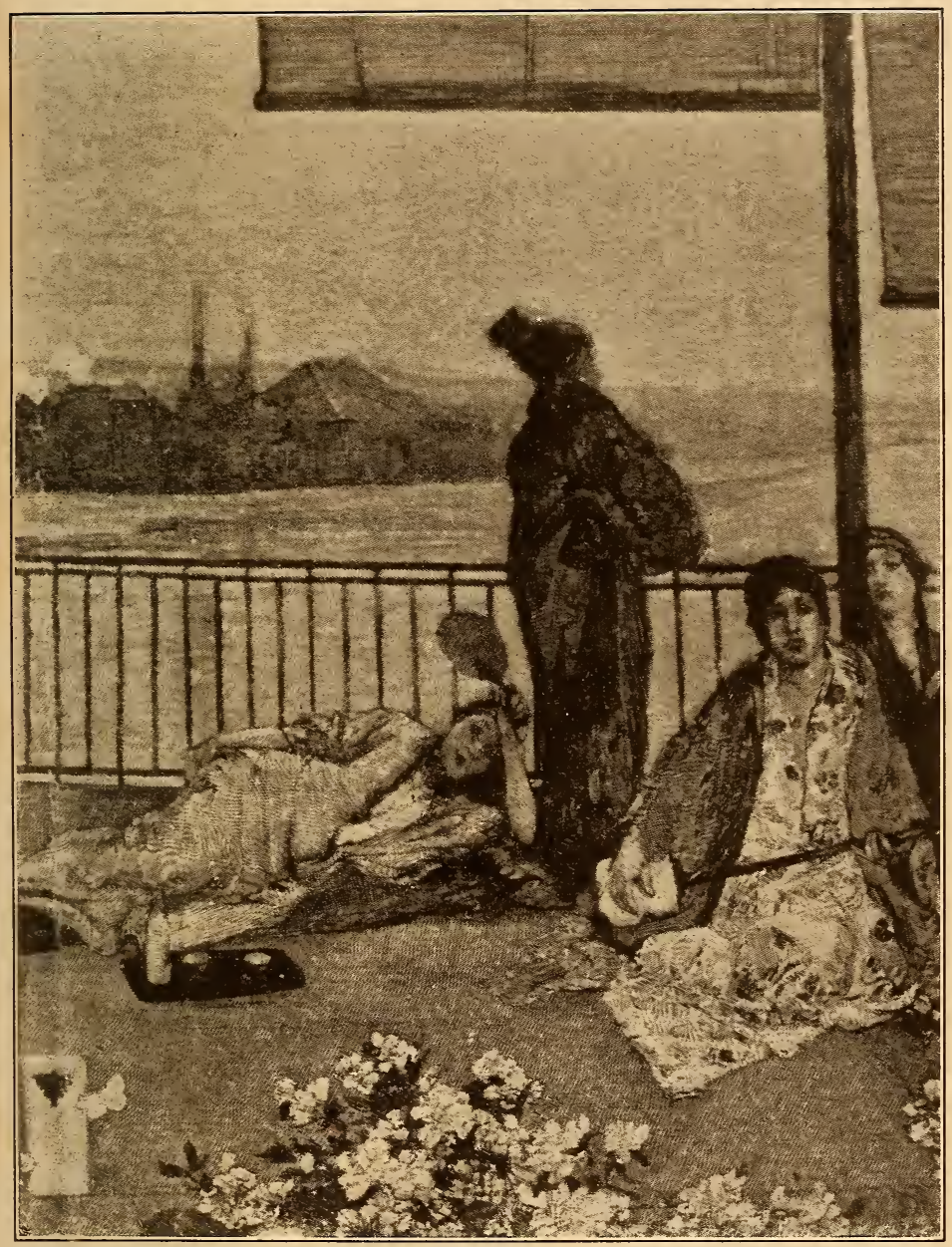

National Gallery, Washington

ON THE BALCONY: VARIATIONS IN FLESH-COLOUR AND GREEN. 
essayed the same task as Chavannes in his mural decorations, i. e., to determine the local tints of each face or arm by the surrounding colours. The problem was made still more difficult by showing each face in a different illumination. One face is silhouetted in profile against the river, another shaded by a fan and the form of a standing figure, the others are seen in front light. I do not believe he has ever attempted a more ambitious problem, and he solved it in a most subtle and convincing fashion. It is a delightful harmony in colour, and exceedingly well-balanced; it reminds one of the Japanese, but the colour and vibrating atmosphere is Occidental. Pity that he found it necessary to introduce Japanese costumes. I perfectly realize that one of the principal charms of this picture is the incongruity of the ensemble. Yet who ever saw in a London town such a balcony with Japanese awnings, and English girls dressed up like geishas, whiling away the early hours of the night. The figures belong neither to Japan nor Great Britain. They are simply there for colour's sake, but, after all, such associations of thought, no matter whether in paint or poetry, never constitute the greatest art. The composition is more restful and simpler than in his earlier works. When Whistler began to 
realize this shortcoming of his earlier style, he turned away from " orchestral explosions of colour" and "volleys of paint," and began that wonderful process of elimination which helped him to become one of the greatest painters of the nineteenth century.

In his later work Whistler returned once more to vivid colouring. It was solely in pastels and water colours, never in oils. And the butterfly, the symbol of Whistler's individuality, fluttered gaily from picture to picture, from print to print, and letter to letter; now disappearing in greyish mists, then peeping forth from a dark olive background, and again asserting his existence at times as a mere shadow, as a dark or coral red silhouette. Changing his colour and size on every canvas, he is now shaded blue, brown, rose, red, violet or peacock blue and then, suddenly assuming unusually large proportions, he spreads his wings in full flight to be lost once more as a grey, almost imperceptible spot, in some twilight atmosphere. At one moment he appears on a vase, a rug, or a curtain. He floats on the sea, rest on doorposts, wings his way over flowers and rocks, shifts sportively from the lower left to the right corner, thereupon rises to almost the middle of the canvas, flutters around the figures, even touches their forms 
delicately, as a dainty creature may do, and continues his endless variations and gyrations; ever ready to assert the final approval of the master. 


\section{CHAPTER IV}

\section{THE ART OF OMISSION}

A BLUE-BLACK night, broken by sparks of bursting skyrockets and weird forms of light, in which two illuminated towers are vaguely indicated. To the left a cluster of foliage and a crowd of people, felt rather than seen. Such is the subject matter of this little $17 \times 23$ canvas which probably excited more controversy and discussion than any other of Whistler's pictures. It was scarcely noticed when it was first exhibited at the Dudley Gallery in October. But in $\mathbf{1 8 7 7}$ the storm broke loose, and the famous libel suit against Ruskin, and the record of all details of the trial in a browncovered pamphlet, under the title "Whistler v. Ruskin, Art and Art Critics" (in 1878), were the immediate results. And the discussion con or pro has not ceased to this very day. Some call it merely a clever sketch; others consider it one of the highest expressions beauty is capable of.

What is there so remarkable and fascinating in this picture, that it can exercise such an in- 


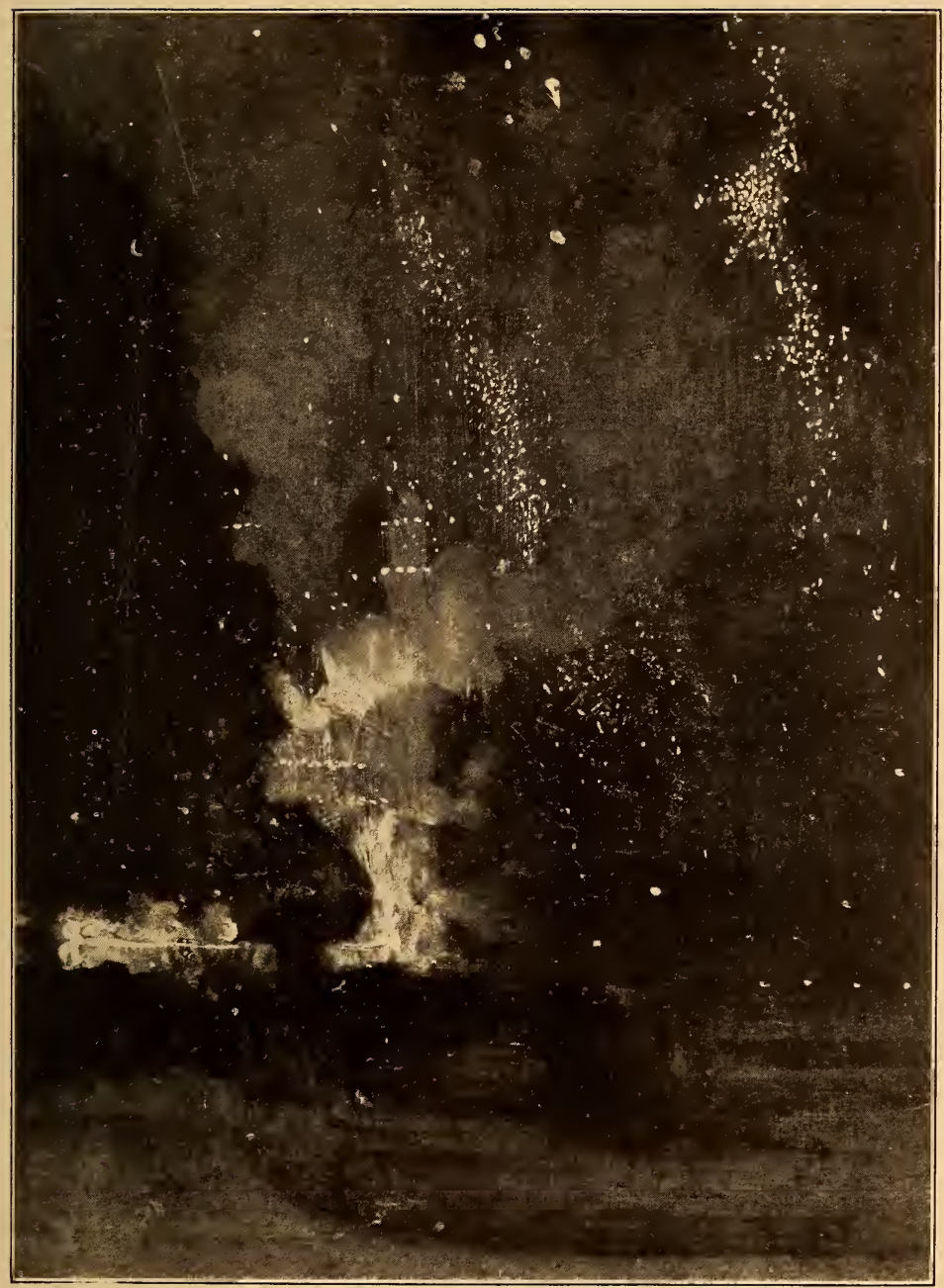

Owned by Mrs. Samuel Untermyer NOCTURNE IN BLACK AND GOLD: THE FALLING ROCKET. 

fluence! Technically it is not perfect, the blacks are rather opaque, and it does not possess the haunting charm of the "Old Battersea Bridge" or even of the "Valparaiso Harbour."

Is it the subject matter? Fireworks were never painted before, or, at least, did not constitute the sole motif of a picture. Yet this should be no objection. Fireworks are one of the modern amusements that enjoy great popularity. There should be no objection to their representation, as little as to a baseball game, a prize fight or any realistic phase of our personal life. The curious interest of this painting, or any of Whistler's nocturnes, does not lie merely in the novelty of the subject (i. e. novel to pictorial representation), nor that it depicts the mystery of night in an unusual manner, as some artists and writers claim.

Its significance lies much deeper. It actually represents the beginning of a new way of painting, not merely of atmospheric conditions, but of an art different in its intentions from any previous form of representation.

During the trial Whistler himself gave the following definition of a nocturne:

"I have perhaps meant rather to indicate an artistic interest alone in the work, divesting the picture of any sort of interest which might 
have been otherwise attached to it. It is an arrangement of line, form and colour first, and I make use of any incident which shall bring about a symmetrical result. Among my works are some night pieces, and $I$ have chosen the word 'Nocturne' because it generalizes and simplifies the whole set of them."

After Whistler had stated that he had worked two days on the "Falling Rocket," the General Attorney said:

"The labour of two days, then, is that for what you ask two hundred guineas?"

To which Whistler replied:

"No - I ask it for the knowledge of a lifetime."

This is hardly a satisfactory explanation. It merely informs us that the consideration of line, form and colour is more important than the incident depicted. Have not all painters worked in that way! The actual manipulation of the pigment on the canvas is the supreme pleasure of every genuine painter. But the source of inspiration after all lies in the incident that is in the line, form and colour indicated by the incident. Or does Whistler wish to convince us that he mentally invented a colour scheme and then set out to find the incident? He might have said to himself, "I want to paint a night scene, in blue and gold, and 
I want such a silhouette to dominate the scene," but, after all, the incident had to furnish, or rather suggest, the possibilities of the mental vision. He, more than most painters, saw poetry in nature. His wonderful description of a river scene at night in the "Ten O'clock" vouches for that. Read these lines that are worthy of any poet:

"When the evening mist clothes the riverside with 'poetry' as with a veil, and the poor buildings lose themselves in the dim sky and the tall chimneys become campanile, and the warehouses are palaces in the night, and the whole city hangs in the heavens, and the fairy land is before us - then the wayfarer hastens home, the workman and the cultured one, the wise and the one of pleasures cease to understand as they have ceased to see, and nature, who for once has sung in tune, sings her exquisite song to the artist alone, her son and her master; her son in that he loves her, and her master in that he knows her."

A man who wrote like that surely received his inspirations from nature, and was dependent on the incident as much as anybody else. No, the true significance of his nocturne, as remarked before, lies in the original intention, not in the final effect of the subject he wished to produce. For conventionalist and impression- 
ist alike, nature is the source of symbols for their mood. With them the standpoint is remarkably different from that of the superficial realists, who imagine that the mere copy of a scene must give the emotion that the scene itself arouses; who forget that the artist's emotion is as much a selective factor as his vision of the objective signs needful for the communication of his feeling to his public.

He probably wished to remain under cover, and not come out boldly and say: "This is the Japanese way of doing things. I disengage the poetical significance from an object or fact in Eastern fashion. I have learned this from the Hiroshige prints."

Few artists are willing to lay bare the mechanism of their individual way of interpretation. They would be misunderstood anyhow. Painters would have rejoiced to call him a downright imitator. And that is just the point where he differed from the average artist who followed the Eastern trail of art. $\mathrm{He}$ succeeded in combining the two great art elements of the world, those of the East and the West. In the sixties he was interested merely in a phase of Japanese art, that of colour. Hiroshige prints were hung on the wall or scattered on the floor of his studio, as can be noted in several of his earlier paintings. The Japanese 
artists were virtuosos of colour. They combined the most contradictory colours into a harmony, nuances which for centuries had escaped the appreciation of the European eye. After many experiments Whistler realized that this refined sense of colour was only one of the external accomplishments of Japanese art, that its true soul was revealed in its suggestive quality.

The Japanese artists work without perspective, shadows and reflections, and even when they apply them they do so in a purely decorative way. They rely entirely on design, on line and the juxtaposition of flat colour shapes. They do not care to produce an illusion, as if the frame afforded a view on a scene of actual life. They are satisfied with making a mere delineation, a suggestion of a beautiful gown or mountain view.

In literature, or even in such a simple matter as the naming of things, the Japanese invariably give play to the exercise of their imagination to bring out a suggestive effect. The same tendency extends into their fine arts. In treating objects of nature, however insignificant, the Japanese artist strives to suggest or indicate some sentiment beyond what is conveyed by the facts represented, just as the poet strives to store up a mine of thought in the 
thirty-one syllables of an ordinary verse, the Tanka, or in the still shorter Haikai of seventeen syllables. In short, the Japanese artist exerts himself to produce more than beauty of form or colour. This quality is less apparent in the coloured wood print so popular with Westerners. An Outomaro is really lacking suggestiveness. It runs too much into technical detail, and just for that reason perhaps we more readily understand the European artists.

Take for instant a simple representation of summer plants, merely a few stalks. The artist is not satisfied to show us the actual facts but endeavours to indicate something beyond what is actually represented, the delight of a flowery field in summer or the cool refreshing breeze under which the plants are bending and swaying.

The Western artists hitherto entertained a different ideal and though there were many schools, each advocating a different ideal, they all agreed on one point: that they had to create an illusion, with modelling, rotundity of form, light, shade and distance. Suggesting a fact is subtler than actually representing a fact. A sketch has something, a virility and freshness that a finished painting rarely has. We prefer Courbet to Ingres, Israels to Leigh- 
ton. There must be something left to imagination, to our emotions and æsthetic consciousness. The Japanese leave most to imagination. Their method lacks strength but is capable of conveying finer poetic sentiments. Their vision is clearer, more rapid and less disturbed by intellectual preoccupations than ours. They are perhaps more perceptual than conceptual. Not that they lack deep poignant expression, but that they are deficient in intensity and depth of representation. The grandiose unity of effect of a Titian, Tintoretto or Rubens is beyond the kakemono and colour print. They succeeded in some instances in adumbrating in lines of conventional severity and precision strange and mystical intimations of spiritual existence. But we find it difficult to discern these qualities as we need more than suggestion to arrive at such conclusions.

Whistler tried and succeeded in translating this suggestiveness in such a manner that the Western mind could understand and appreciate it. How did he accomplish this task! He realized that he could not abandon atmosphere, light and distance. He had to apply the Eastern principle without deteriorating the Western technique. To proceed like the Japanese would have resulted in a failure. His "Princess of the Porcelain Land" must 
have taught him this. He strove for something else than a mere resemblance. He adopted certain ideas of space arrangement, certain forms of design and the elimination of detail. The underlying composition reminds of the Japanese, but not the finish.

Hiroshige was the first designer of Japanese colour prints who devoted himself largely to landscapes with figures, and with Eastern ingenuity almost exhausted the subject. His "Hundred Views of Fusi-yama" contain the most startling designs and problems of composition that have ever been attempted, and they are treated with incomparable boldness, and solved with astounding skill. The rarest aspects of nature are treated with perfect balance. It is a play of curves and geometrical shapes that bewilders the Western mind that has been content with comparatively few formulæ.

The vista idea of representing a scene as if viewed through the frame of a doorway, which Whistler so frequently used in his etchings as in "The Lime Burner" and "The Garden," is strictly Japanese. One of his friends said that Whistler never objected to any one trying to copy his way of painting, but looked upon filching of ideas as grand larceny. This proves how ignorant we all are about our con- 


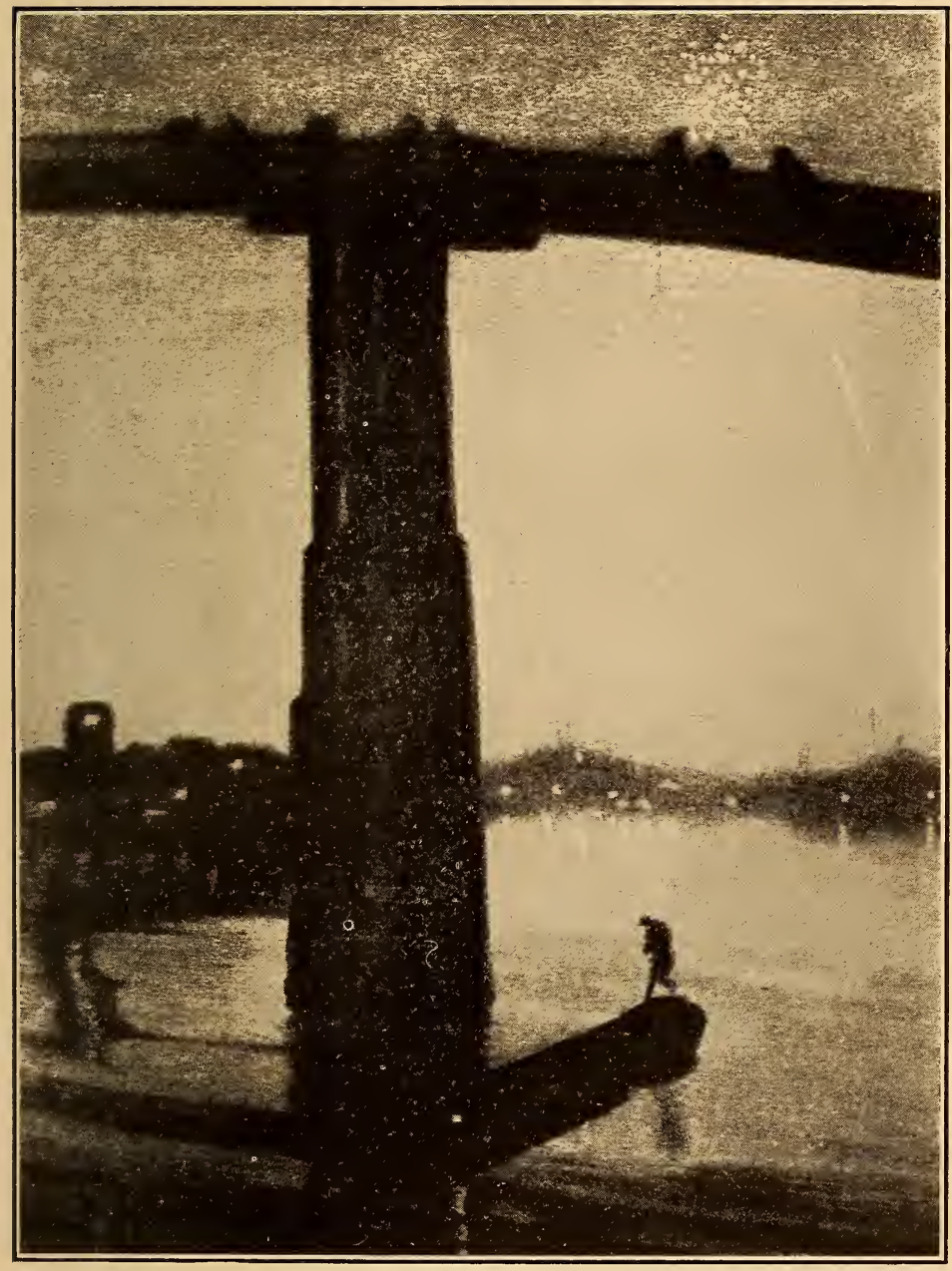

Tate Gallery, London

NOCTURNE IN BLUE AND GOLD: OLD BATTERSEA BRIDGE. 

duct of life. If anybody ever plagiarized ideas it was Whistler. The " $T$ " shape of the "Old Battersea Bridge," in his nocturne of blue and gold, is almost an exact copy of a Hiroshige design. The same can be said of the branch of leaves protruding like a silhouette from the margin of his "Ocean," and the composition of several other nocturnes. But Whistler added something which no Japanese print suggests. He added light, atmosphere, distance and mystery.

Hiroshige relied entirely upon design and line, and he was not a good draughtsman at that, at least not in his figures. His human figures frequently look like miniature caricatures or curious little insects. His line lacks purity and sweep, but is more realistic and less conventional than that of his predecessors. His colour is crude in comparison with the older artists. His prints that were executed after the introduction of European aniline colours in 1850, with their streaks of vivid red and blue, are almost offensive to the eye. His earlier ones, when he was content in working in pale colours, in pale blue and black with just a suggestion of pink, are vastly superior. Later on he tried to learn from the Europeans, and strove for atmospheric effects, but always suggested it rather by design than colour. If 
he used colour for that purpose it went never beyond a simple wash.

Whistler sacrificed line almost entirely. $\mathrm{He}$ worked in big masses, shapes and silhouettes and made colour the principal attraction. The simplicity of design he borrowed from the Japanese, but the intimate charm of his colour he got from another art, the art of music. Many paintings of the latter half of the nineteenth century show this musical tendency. Chavannes, Cazin, our American landscape painter Tryon, even the Impressionists, try to produce with colour something similar to the effect of sound. It is either a resemblance of feeling in execution, or the desire to deliver us over to a mood like music. Generally both desires go hand in hand.

The painter, to accomplish this, must go back to the emotional elements of things, to view objects with primitive enthusiasm and to disregard all cumbersome detail. These qualities must dominate his conception, and his treatment must be slightly decorative. $\mathrm{He}$ must see things flat, in curious shapes, and then juxtapose and complement his colours in such fashion that they produce instantaneously a pleasant retinal image. In most paintings the subject matter attracts our attention first, and the appreciation of its technique reaches our 
emotion through a mental process. A Chavannes fresco and a Cazin landscape, on the other hand, appeal directly to our emotions. Henner, Corot, Carrière are musical, Leighton, Dagnan-Bouveret, Böcklin are not. Chavannes and Tryon construct their compositions like a composer his score. By applying parallelism of line and repetition of form and colour shapes with slight variation, they attempt to transpose musical conditions to the sphere of colour.

Cazin goes further than either. He comes nearest to Whistler. He actually tries to make the colour sing, not a composition of diversified interests, but a simple sweet melody that instantaneously produces a distinct lyrical emotion. In his best pictures he reproduces successfully the perfect harmony of a few fugitive tints, such as occur so frequently in nature by a combination of the evening sky and a shimmering surface of water, by a white cottage in moonlight, or desolate marshes against a starlit sky. In this, Whistler excelled. He advanced another step by using the smallest limit of colours possible, without obliterating form and subject matter. Although Whistler accentuated the breadth of vision, divided his space arrangement into as few planes as possible, juxtaposed rarely more 
than two colours, and made all objects appear shadowy and weird against a glimmering sky, it is astonishing how vibrant he kept his colour; the more so as his colours are laid on rather flatly, and, occasionally, so thinly that the canvas shines through. This, of course, helps the vibrating quality, but the colour tints contain so many subtle variations that they scarcely become discernible to the eye but

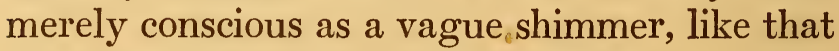
of night and atmosphere themselves.

The colour combinations are frequently the same. Blue and silver, and blue and gold appear most frequently. Then there is brown with gold or silver, and a crepuscule in flesh colour and green, which was also the theme of " On the Balcony."

His subjects were chosen with great discretion. Outside of the "Valparaiso Harbour" picture, a "Southampton Water" and a "St. Marks, Venice," most were devoted to London. There is a Chelsea embankment in winter, a Chelsea in snow and ice, the Westminster Bridge, the Trafalgar Square in snow, and the old Battersea reach and bridge in three versions. Whistler never stopped work at a picture until it was as perfect as he could make it. Many of the pictures that are now on the market, mere scraps and fragments at ridic- 


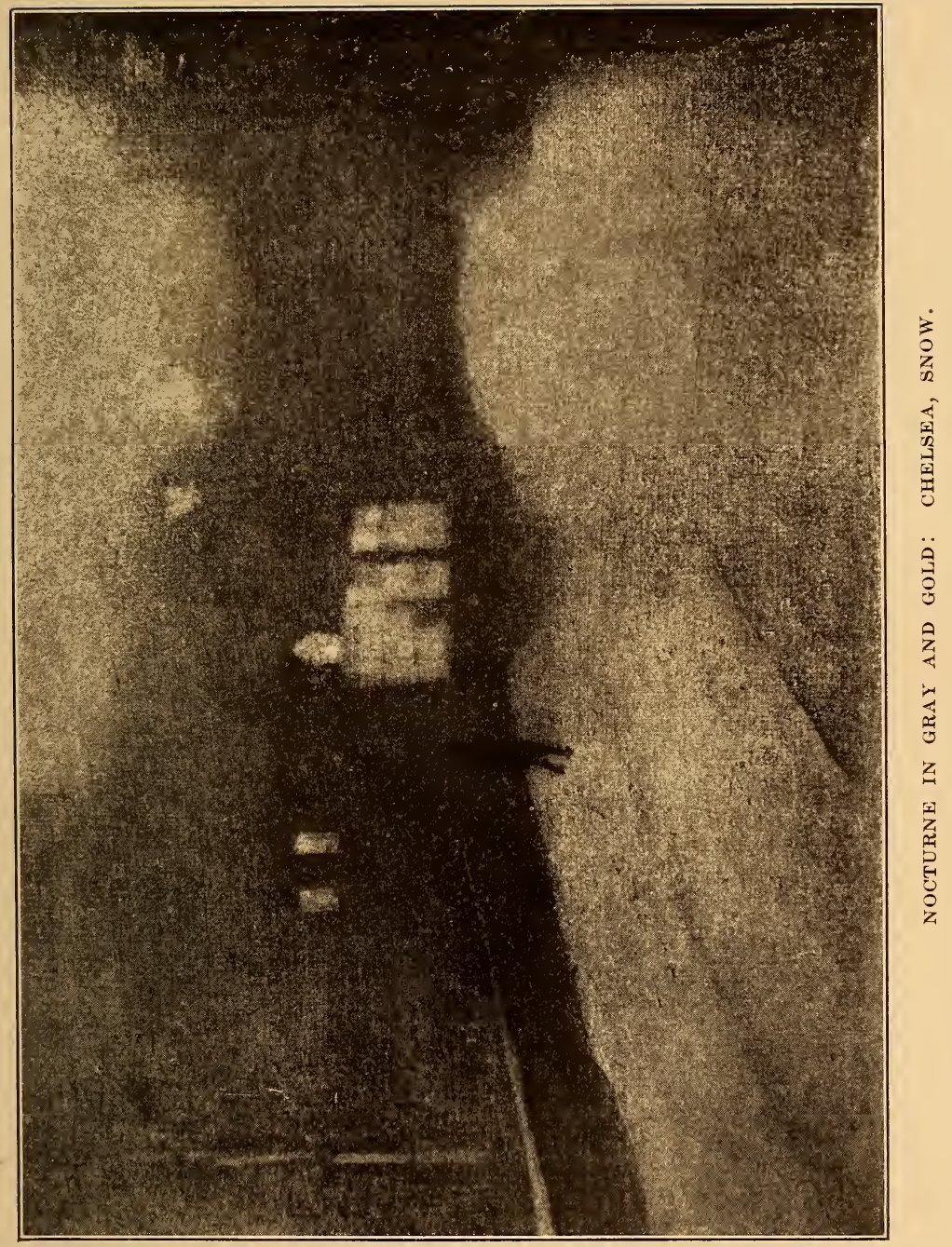



ulous prices, he would not have allowed to go out of his studio. He had the conscience of the true artist, but he never went to the extreme. He knew when to stop, a quality which is exceedingly rare. $\mathrm{He}$ would never have spoiled a canvas as Maris and Ryder do. He worked very hard on most of his pictures, but they do not show it. The difficulties and deliberate slowness of execution are lost in the final result. "To say of a picture, as it is often said in its praise, that it shows great and earnest labour, is to say that it is incomplete and unfit for view." He followed this maxim out to the letter. Industry was with him a necessity - not a virtue. Were you to ask me to define the charm of his nocturnes, I should say, I fancy that it lies in the delicious purity of their expression. The emotions which Whistler wishes to excite are those of visional pleasure, of subtle speculation and vague emotional joy. In him inspiration always prevailed over caprice. The picture had first to express the arrangement of colour entrusted to it, and was scarcely allowed any dash or extravagance of brushwork or form, unless they would form a part of his original plan and serve as a contrast or dissonance. He never added anything in his repaintings, but cut out one passage after another; he did not graft on, he pruned, for 
he meant nothing should remain but the most essential. If there was ever a man tormented by the accursed ambition to put the whole world into one picture, the whole picture into one tonality, and the whole tonality into one colour note, it was Whistler. It is difficult to understand why his work was ever criticized as being unfinished. When Burne-Jones, in a spirit hostile to Whistler's work, declared in the witness box at the Ruskin trial: "In my opinion ... a picture ought not to fall short of what has been for ages considered as complete and finished," Whistler retorted effectively: "A picture is completely 'finished when nothing more can be done to improve it."

And for this finish he tried incessantly. There was never an artist who was more conscientious and more ardently striving for perfection than he. He sometimes tried experiments with different mediums in oil painting. At one time he used benzine to thin the colours, another time kerosene. He would cover a large canvas all over with the latter, in order to bring out the dried tints, before he started to repaint or overpaint. And he said to Clifford Adams, his last apprentice, "In the morning we may not succeed in getting the direct relation of colour, but at noon it may become more harmonious and at sundown we might strike 
just the right thing." And so he worked, day after day and year after year, on his pictures, until every trace of labour was obliterated and the picture had become a masterpiece. "A masterpiece that would appear as a flower" to the painter - perfect in its bud as in its bloom - with no reason to explain its presence, no mission to fulfil; a joy to the artist, a delusion to the philanthropist - a puzzle to the botanist - an accident of sentiment to the literary man."

This flatly contradicts the general idea rampant among painters that he furnished his paintings au premier coup. His friends endorse the denial. Mr. R. A. Canfield has seen not less than sixteen changes of background to one portrait,." and heaven knows how many more that were not counted." Whenever he was dissatisfied with a painting, he started a new canvas until he finally realized the task he had attempted. In that sense his colleagues are right, his pictures look as if they were painted au premier coup, but it was a roundabout way. It is impossible to advance any theory about his technique. All his pictures are painted in varying thicknesses of paint, in varying degrees of liquidity of paint, in varying smoothness and roughness, in few or many sittings, in fact, in the varying technique which alone 
can correspond to moods of so great a painter and the circumstances of each picture.

The only thing which has any semblance to a constant method is a moderate adherence, in his portraits at least, to the old way of painting from dark to light which, in the final painting, in overlapping pieces of paint, as in the case of most oil paintings until recently, results in the thickening of the paint towards the light.

There are scarcely more than sixteen finished nocturnes on record. Of these, most are masterpieces, or would pass as belonging to the best of his works. And as he worked at them ever since he returned from Valparaiso in 1866 and held the first important exhibition of nocturnes at the Dowdswell Gallery, and in Paris (in the Rue Sèze) not previous to $\mathbf{1 8 8 3}$, when quite a number were still unfinished, we are astonished at the small output. But masterpieces are scarce. And if a painter can be credited with two or three every year he is a hero in his profession.

The importance of the nocturne in Whistler's own career, everybody must realize who is familiar with his work. They add to his personality a delicious flavour that even his lithographs and large paintings do not grant in the same manner. It was to him an instrument 


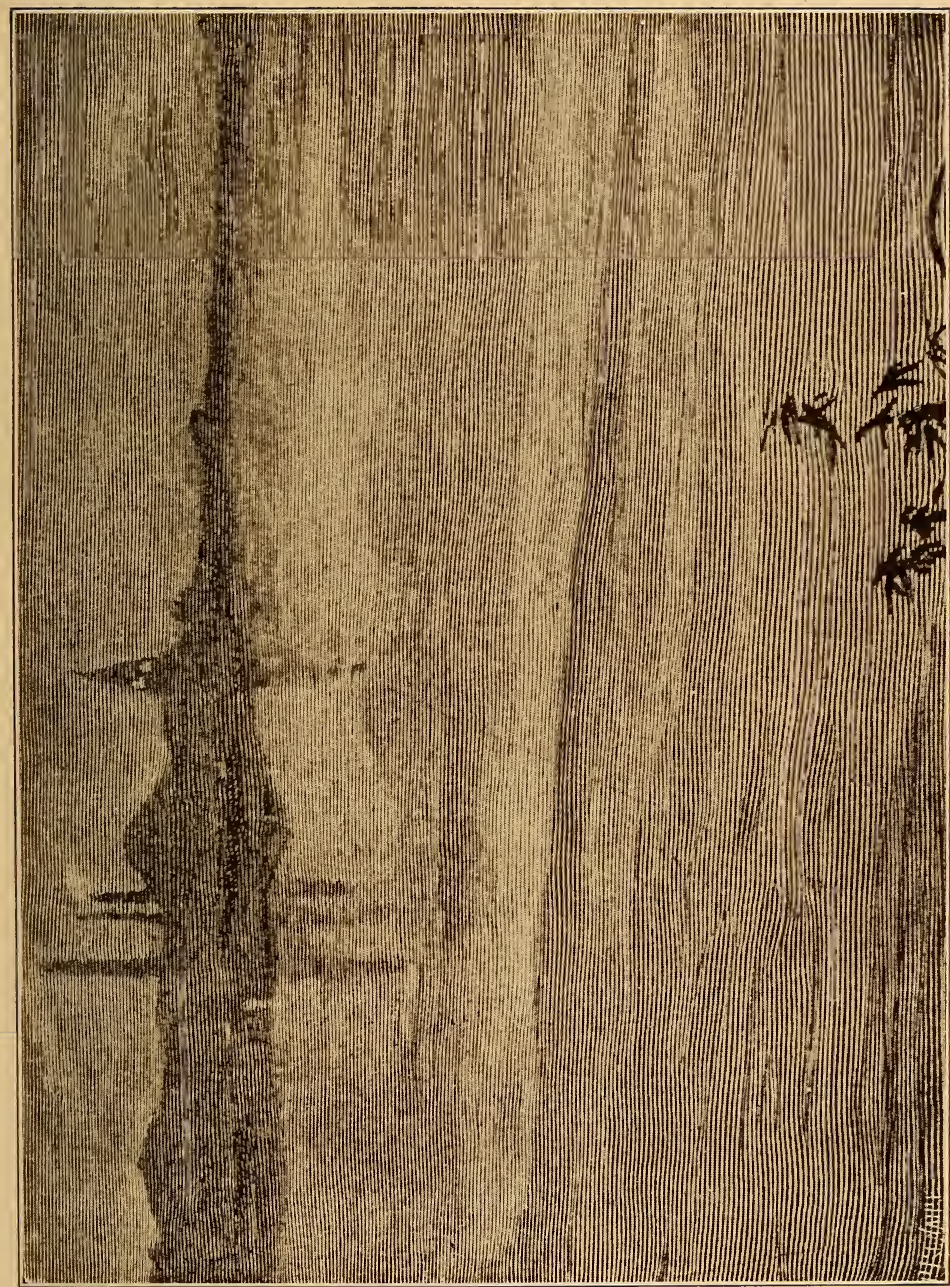

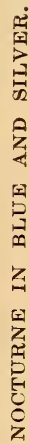


that obeyed his slightest wishes. It was art, at once aristocratic, delicate, of high finish and moreover imbued with an individual rhythm and the poetry of nature.

What wonderful rain and snow this man has painted! What vast expanses of water as mystic as the night! And those vagrant mists, that envelop everything and blot out the very existence of things! There has not been anything in art since Turner that could be compared with it. There are no banal sunsets, no glaring moonlights, only the more intricate moods of nature, snowfall, mist, late evening and night. Also in the choice of his subject he added a new note.

The art of a landscape painter is determined by a thousand influences upon his mind other than those of nature. The essence of Monet's art is one of an hour, but with such a painter as Daubigny or Rousseau it is one of a place. There is the sense of the atmosphere of the moment given by one school of landscape painters, of locality by another, poetry by a third and of the historic associations of a place by yet another school. These things are, of course, determined by temperament, and schools of painting may be classified in this way more adequately than they are. Human association creeps into landscapes in various degrees, and 
also in other ways than the historical way which we feel, - as in F. E. Church's pictures, for instance, - but landscape, generally subordinate to the human interest, now sometimes tries to free itself from this influence entirely. It has become like poetry, simply the record of an emotion or mood remembered in colour. This is Whistler's peculiar innovation.

And yet the final significance of the nocturne in the world of art is still an open question. Time alone can decide its value. The rest is mere hypothesis. Many - and I only talk of people who understand - argue that despite its perfection, the nocturne represents a minor phase of art. Of course, a nocturne, no matter how beautiful, cannot compete in importance. with the "Portrait of Carlyle," or "The Artist's Mother." Size does not mean much, but it means something. A small painting can be as exquisite in workmanship as a large one, but it can never rise to the same dignity of expression. A frescoe by Chavannes would lose much if executed in the size of the average easel picture.

But the nocturne stands for something in modern art which lends it special importance, aside of all workmanship and beauty of pictorial treatment. It represents a return to the art of painting for painting's sake. Every art, 
may it be music, poetry, dancing, sculpture or painting, has its own peculiar technique, which the technically ignorant person cannot appreciate. Poetry which has no formal conventions is inconceivable. And, in a similar manner, painting has the charm of texture and brushwork, the charm of how the paint is actually put on and displayed on the canvas. The æsthetic satisfaction derived from an art is in exact proportion to one's knowledge of the art's technique.

This largely explains the general public's indifference to art. And the everlasting fight between the artist and the public has been on these lines. The plea of the modern experimentist that all poetry of painting should be in the paint, which also Whistler advanced, is a just one if not carried to extremes. Absolute paucity of idea is as unfavourable as storytelling. The intrinsic beauty of a painting lies in the method of painting, and the only guide for the painter is colour and the general arrangement - not a method learned by rote, not an arrangement garroted by a thousand rules which others have invented, but that personal style or rhythm which is inveterately the painter's own. So Whistler's style is beautiful because it is personal. His revolt was against story-telling, against the genre pictures, which 
adulterated painting with the skill of the novel writer. It is for future æsthetics to decide whether the introduction of musical ideals is not just as dangerous as the intermixture of any other art. There is no doubt, however, that the new combination grants a higher pleasure to the connoisseur at present. Music is the most fashionable and, perhaps, most widely understood art to-day.

This be as it may, Whistler did a great service to modern art. By realizing its limitations he bestowed upon it a new vitality and glow. His art, far from being lawless, is the expression of a new law. Make any kind of pictures you like, dear painters, provided they are beautiful. For each age there is a different beauty. Old forms and old perfections wither.

There has been too much story-telling. The David school, with its pompous historical, allegorical and mythological representations, has become intolerable to us. David, Vernet, etc., up to Ingres and Delaroche all seem lifeless. Also the Romanticists, who were the interpreters of poets, appear highstrung to more recent art ideas. The reaction was inevitable. The Impressionists - and their merit lies principally in that their work represents a technical reaction - went too far, inasmuch as it allows 
scarcely any scope to intellectual expansion. It is based on immediate vision, and occupies itself only with the consideration of light and colour, and keen observation of modern life. All the great painters met the public half way. The great painters, we need only to recall Rembrandt, Velasquez or Leonardo, were painters as much as they were poets, but each in equal measure. The qualities balanced each other, and they did not, like the modern painters, sacrifice one for the other.

Whistler has to be classified as an Impressionist, but he remained true to the old tradition. He was as much a reactionist against classic and romantic painting as any of them; but he had no use for the new technique. Like Monet, he went back to Velasquez and Goya, Franz Hals, Van Dyke and all the Old Masters who could paint. Like Courbet, he reduced a scene to three or four broad tones, but he was more exact in the grade of tones, and invariably endeavoured to explain the sentiment inspired by them. His work was never anti intellectual. On the contrary he was a true visionary.

He protested against literary elements, but emphasized the psychological and symbolical qualities of painting. Nobody was further remote from gross superficial realism. Like 
Flaubert and the Goncourts, he proved that realism can go hand in hand with refined form and delicate psychology. $\mathrm{He}$ was sane throughout. And that is why the æsthetic revolution, produced by him, is not yet at an end.

The first principle for the painter is to acquire a personal mode of feeling and thinking, and the second that he should find an adequate and personal method of expressing himself. The painter must choose his method. If he has only the old themes to paint the old forms will suit him well enough - portraits and single figures, landscapes and marines, cattle pictures and still life - but if he has anything special to say, he must find for himself a special and unique form of expression. The only criterion is beauty. 


\section{CHAPTER V}

ON LIGHT AND TONE PROBLEMS

IN his "Art in the Netherlands," and his various books on Italian art, $\boldsymbol{H}$. Taine has maintained that the hand of the mediæval painter was largely guided by optical sensations. And, following this rather suggestive, than conclusive, trend of argument, we will readily perceive that the peculiar lighting. conditions of those days, the semi-darkness of the interiors, the play of sunlight dying in the obscurity of shadows, and the absence of strong artificial lights have done much to disclose to the genius of a Titian and a Rembrandt the manifold harmonies of chiaroscura, of colouring, modelling and emotion. The tallow candle, the oil lamp, the torch and the open fireplace were the only artificial light appliances known to the Middle Ages, and they were all only like solitary rays of light in universal darkness. Illumine a room by night, by placing a candle on the table or on the floor, and judge for yourself. The effects obtained, no 
doubt, would appear to you as weird and picturesque. 'The flickering light is uncertain, the shadows are intensely dark and pronounced, almost crude and vacillating, as if engaged in a continual combat with light. The contrasts are startling, yet not discordant, the vague train of light mingled with shadows accentuate only a few places with vivid spots, perchance the polished surface of a piece of furniture, a glass or pewter mug on the table, the collaret or jewelled belt of some fair lady. The eye is led to noticing gradations of obscurity, the darkness grows animated with colour and form, and we see the objects as through a glaze of Van Dyke brown.

No wonder that the painter of the Middle Ages, having become sensible to the beauty of transparent darkness and the brilliant passages of light, dared to unite extremes and to show every form and colour in its full strength. The vagueness of chiaroscural effects was the great modifier which enveloped all adjacent objects in clair obscure and tempered them with a warm and mellow radiance.

How different are the conditions in our time. There are no more Schalcken or Rembrandt effects. We have succeeded in banishing darkness from our homes. We have become very sanitary, we want light and air, the walls of 


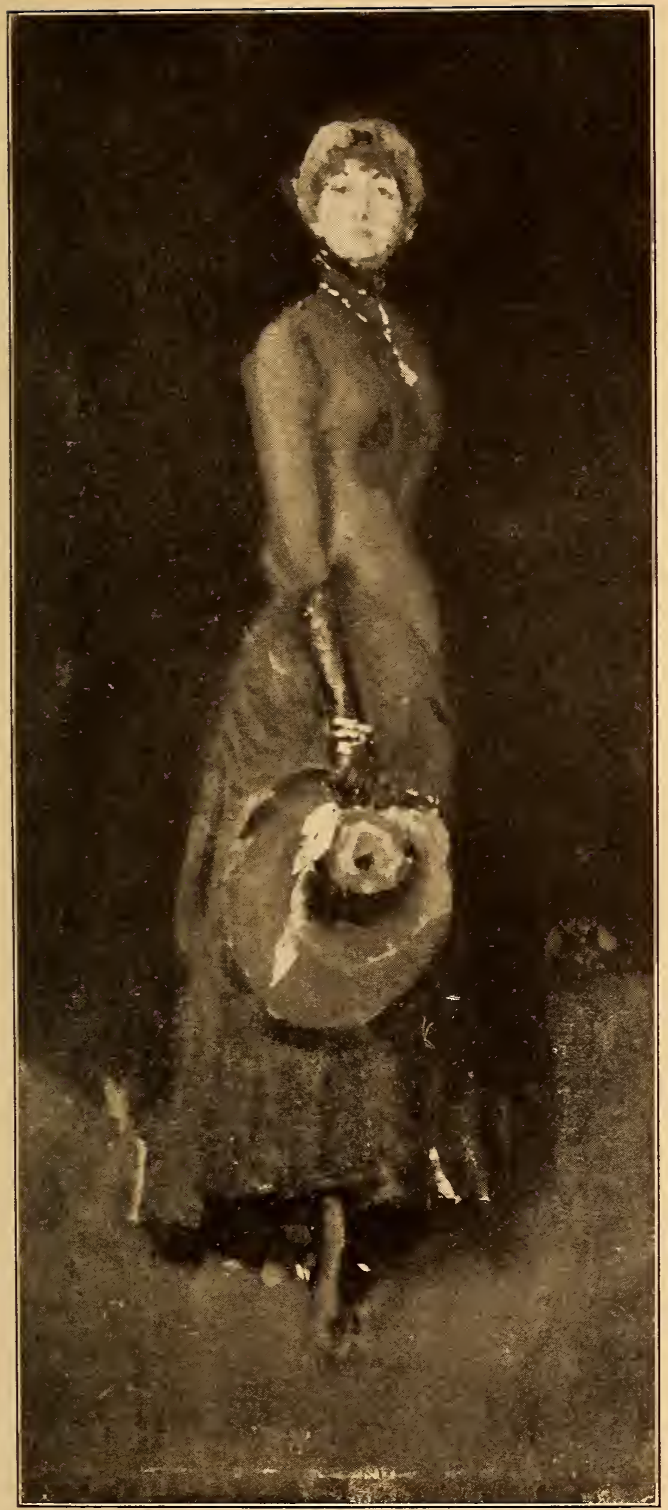

Courtesy of the Metropolitan Museum, New York LADY IN GRAY. 

houses are built less substantial, and through the increased largeness and transparency of panes, the daylight streams in with dazzling vehemence. It penetrates into the remotest nooks and corners. Even at dawn the shadows are only vaguely dark, of an uncertain and mixed bluish grey. Lenbach, the portrait painter, realized this deficiency, and found it necessary to construct a special studio, where the light was only sparingly admitted through deep casements, and where the sitters for his old-master-like interpretations of modern characters were placed far away from the windows.

The greatest havoc among chiaroscural effects, however, has been played by modern light appliances. Gas and electric light, with their various modifiers and intensifiers, have killed all the old ideals. There are no longer any striking chiaroscural contrasts or strong accentuations. In the Middle Ages dress and drapery showed depth of folds and recesses which are absolutely unknown to-day. Now, everything is diffused with light. Nothing is steady and fixed, and yet objects stand out in painful relief. The modelling has lost much of its tonal variety, and all objects vaguely reflect the imprint of all-pervading light. The values of colour appear bleached and vary in- 
cessantly. Our eyes are perpetually moving in a restless manner from one part to another, and no longer find any place to rest in the depth of shadows.

Luckily for us, we have been rendered unconscious of these dangers, we have grown accustomed to them, but their influence on modern painting has been a most palpable one. Chiaroscural composition underwent a complete transformation. Saliency of object induced the modern painter for a time, at the beginning of the last century, to strive solely for fixed and precise conceptions of form and to utterly neglect the beauty of light and shade. When he discovered his error, he went to the other extreme, and not merely softened contours, but blotted them out completely. At a loss how to meet this difficulty he lost himself in an intenser and more varied study of illumination, with the aim to reach a higher pitch of light. Lamplight and firelight effects and the contrasts of commingling light rays from two, or even three, sources became the order of the day. Sargent studied the effect of Japanese lanterns on white dresses in twilight. Harrison tried to fix the play of sunlight on the naked human body. Dannat experimented with flesh tones and electrical arclight and magnesium flashlight illumination. Zorn en- 
deavoured to solve in his Omnibus picture the conflict of various lights in a glass-encased interior. Degas and Besnard became enchanted with illumination from below, in the cross lights and the lurid unnatural lights of the stage, and his disciples introduced the effects of footlights into interiors by placing the lamp on the floor.

All these studies address themselves most powerfully to the modern mind, as they depict eontemporary conditions. The eye may be offended or even repelled by unnecessary trivialities at times, but the underlying aspiration is, after all, the truth. From an æsthetic viewpoint it is less satisfactory, as this modern substitute of light and shade composition, consisting of an opposition of colours, rather than of masses, does not afford, in the speech of Herbert Spencer, "the maximum of stimulation with the minimum of fatigue." It contains a discord, a lack of normal gratification, and this shortcoming, in conjunction with the deterioration of the crafts, which were replaced by factory labour, and the hopelessly prosaic aspect of modern dress, as far as colour is concerned, directed the painter into other fields of investigation. He realized that nature had remained unchanged, that the colour-symphony of sea and landscapes, of dawn and sunset, were as 
beautiful as ever, and he went out of doors for inspiration. And then, to his great astonishment, he discovered that the optical sensations afforded by nature were very similar to those he had experienced in his home life, also how everything was diffused with light, and forms rendered uncertain by the vibration of light.

The famous colour harmony of Italian painters, red, green and violet, which aroused action successively in the whole field of vision without exhausting it, seemed meaningless. Strange, apparently discordant combinations of green and blue and yellow, orange and red, which stimulate only certain portions of the retina at the expense of others, obtruded thernselves upon his optical consciousness. It became apparent that light does not emphasize, but that it generalizes, and that colours and tones, although more varied, are less decisive than in the painting of the Old Masters. The charm of pictorial illusion seemed to have shifted from the juxtaposition of contrast to the more subtle and less powerful variety of half tones. It is not so much the richness and fullness of colour the modern painter strives for, as Raffaelli has pointed out, but the combination of colours which yield a sensation of light, which, in a way, is a reflection of our temporary light conditions. That the Impres- 


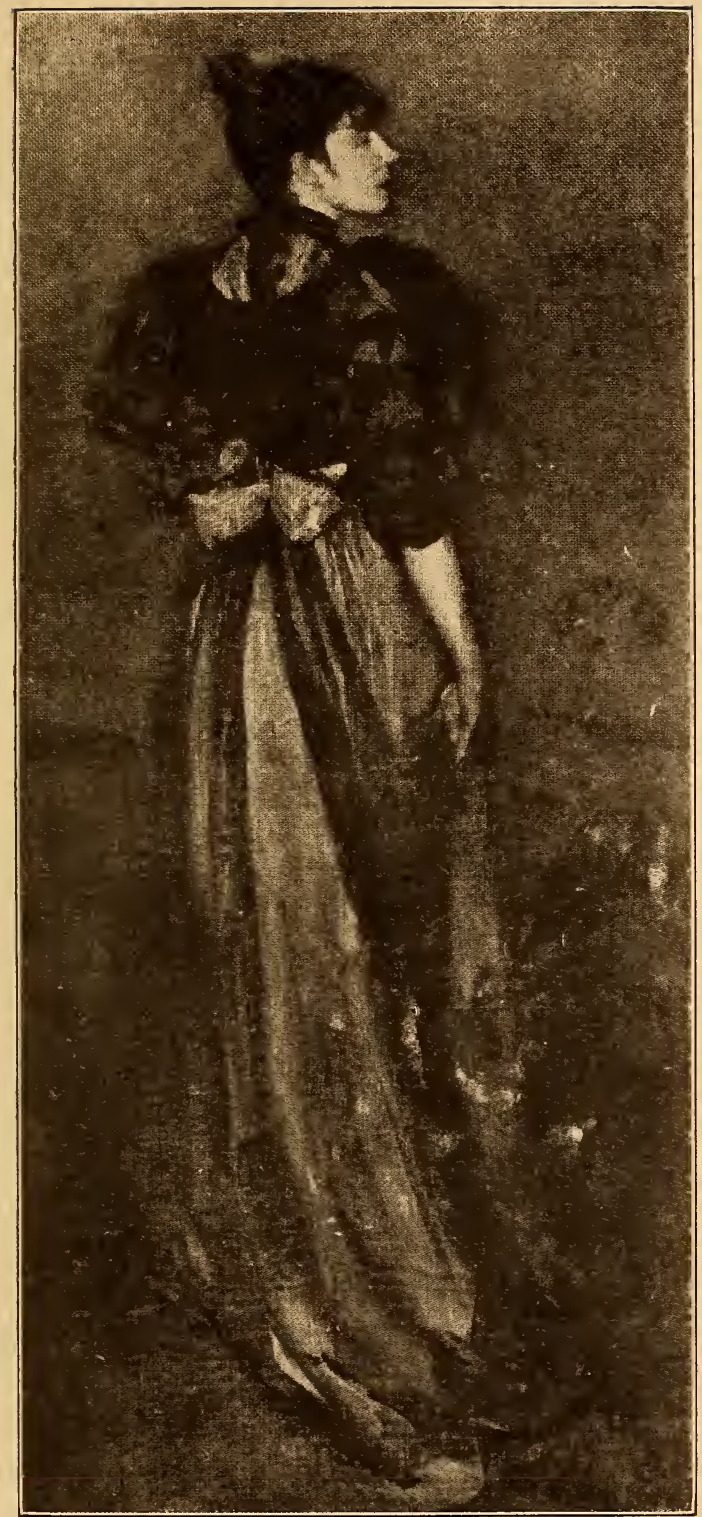

Owned by John $H$. Whitlemore

"L'ANDALUSIENNE." 

sionists banished black from their palette is significant itself.

Ever since the semi-darkness of the Middle Ages was dispelled, the minds of painters had been occupied with the invention of a new method of painting. Chardin and Watteau, who crosshatched and stippled pure colours in their pastels and water colours, were really the forerunners of impressionism. Delacroix was the first master-painter who scientifically concerned himself with light and colour notation, as Turner (viz. Ruskin) introduced the emphasis of the colour of shadows at the expense of their tones. But not before science came to the assistance of the painter, was he able to perfect his system of open air mosaics, of producing tone by the parallel and distinct projection of pure colours.

And it is Chevreul, Young, Helmholtz and Ogden Rood, who, after analyzing colour sensations from a physiological viewpoint and tracing them to their causes, supplied the genius of Manet, Monet and Degas with a new pictorial revelation of light and colour. The modern style of painting is a direct outcome of the environment in which we live. With the decline of candlelight parties the new era was ushered in, and the kerosene lamp was the last harmonizer of light and darkness. As it 
went slowly out of fashion, the reign of half and quarter tones, or, in other words, a new reign of light, of light transposed into tone, set in.

It set in, however, at the expense of everything else. It is largely technical, and the representations are photographic, prosaic, crude and often without the slightest suggestion of sentiment, not even that which an ordinary scene out of doors produces in an imaginative mind. This, more than any other course, estranges art from the approval of the general public.

The subject of an Old Master, although mostly of a religious order and legible to the ordinary mind, at times may have soared beyond the ordinary faculties of comprehension, but the object represented invariably appealed to the sense of sight, as it was painted in such a way as to create an illusion. The Old Masters succeeded in suggesting on a flat surface the roundness and actual colouring of things. The modern painter depicts objects in which the beauty is not always palpable to the layman, and in a manner which is less convincing, as he suggests form rather than actually representing it, and adheres most stubbornly to individual colour interpretation. It needs connoisseurship and technical knowledge to under- 
stand and appreciate the paintings of to-day. The paintings of a Degas, Besnard or Renoir remain a myth even to the people who are fond of art. Comparatively few persons are versed in the thought-transference from colour to sentiment.

Whistler did not believe in the constant mechanical mixture of seven solar tones, which make the eye perform the work which should be done by the painter. He tried hard for the dissociation of tones by endeavouring to translate the flat tints of the Japanese into oil paintings executed in Western fashion, but was not satisfied with the result.

Living in London, with a view on the Thames, he realized that the aspects of modern life have turned grey. They have nothing to do with Oriental embroideries. Our large cities with their smoke and manifold exhalations (not to speak of communities subjected to the use of soft coal) have acquired a dustladen, misty atmosphere. This peculiarity of city atmosphere, however, to be noticed in London and Paris as much as in Chicago and Pittsburg, is a wonderful subduer and eliminator of detail, and should prove a valuable ally in conquering new suggestions of light effects. This Whistler realized, and he used it to express what the inner life of things in modern 
art needed most to express, the poetry of paint expressed in tone and light. "The study of light per se," as Leon Dabo says, "had become a creed with Monet, Manet and their followers. Somehow Whistler's contribution to this naissance - for it was a real birth, first successfully carried out by Constable - has been entirely neglected for the more obvious quality of full sunlight produced by the so-called Impressionists. Whistler's paintings prove conclusively that where there is harmony of colour there is vibration of atmosphere, and, therefore, the illusion of light."

When we stand before the "Mona Lisa" of Leonardo da Vinci and before his less famous, but almost equally fascinating woman of the Liechtenstein Gallery, we do not marvel merely at the lifelike representation, which seems to actually vibrate; but at something evasive and unfathomable that we find difficult to express in words. We experience something similar when we contemplate Whistler's "Mother" or some portraits of modern masters like Blanche, Lavery, enigmatic Khnopff, or the grey men and women of Carriere, who rise so softly and mistily out of the background. Although they have not attained the mastership of the former in the representation of the living, breathing people, there is the 


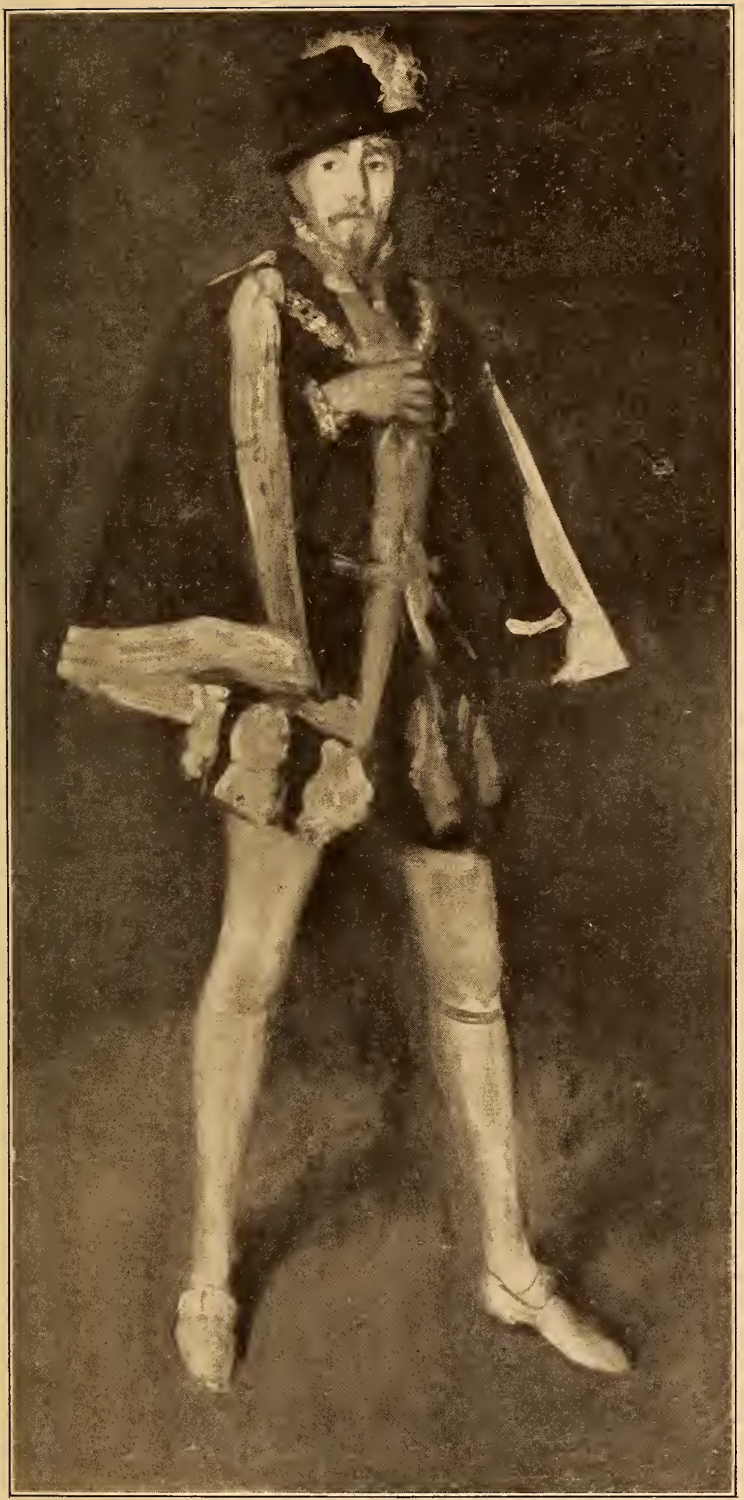

Courtesy of the Metropolitan Museum, New York

SIR HENRY IRVING AS PHILIP II. 

same mysterious mood in their paintings. They seem to quiver with something that is essentially modern, and cannot emanate alone from the charm of momentary expression which is one of their main attractions. The modern figures have a less corporeal effect than those of the Renaissance; they resemble apparitions which have suddenly taken shape in the greyness of life only to dissolve again into shadows. This is more than a technical change, it is a new way of thinking. We concede a new attribute to these painters and call their achievements the "psychological style" of painting. Robert Henri's "Young Woman in Black" is an interesting attempt in this direction.

By this we wish to convey that the figures tell us something of the inner life, and that the way in which this is accomplished impresses us like a commentary on their souls. Of course this is nothing new. All the masterpieces of portraiture, no matter how different technically they may be, whether clear and sharp or soft and diffused, whether by a Raphael or a Rembrandt, Titian or Franz Hals, have the faculty to make us dream and invent some psychical annotation to the figures represented, but modern life is more analytical. We rejoice in dissecting our thoughts, sentiments and 
moods, and some of our foremost contemporaries, though they may wield their brushes as dexterously as the Old Masters, concentrate upon the endeavour to reflect specifically the spiritual qualities and to accentuate its functions as far as it is possible in paint.

The modern painter is fond of specializing, not only in subject, but technically, because he lacks the overflowing energy and strength to conquer all the elements of his profession in one effort. This age, at least in the upper intellectual strata, has become very skeptical. We are not concerned so much about divinities and our future state as about ourselves in the present. Religion no longer furnishes the emotional staff on which we may lean on our pilgrimage of life, and yet we need some spiritual support, some science for the soul, and we may look about for something that may mystify us and lift us above the prose of every-day existence. And this search is mirrored in the endeavour of these men who would like to paint enigmatic figures, like "Mona Lisa" and the woman of the Liechtenstein Gallery.

Conditions change, but not so much that they become entirely extinct. The possibilities for emotional art are to-day as great as ever.

For portraiture, single figure representation and character delineation gentle effects capable 
of subtler gradations are more desirable. They may be found in many out-of-the-way places. A modern Ribera may find endless suggestions for new light and shade combinations in an ordinary cellar, and the picturesque "tavern atmosphere" of a Caravaggio or Terborg can surely be substituted in some obscure nooks and corners of our towns. Our living-rooms show a wealth of still life that, by the play of light, could be turned into beautiful accessories. There is nothing more gratifying to the eye than a bright, haphazard shimmer on some objects while the remainder is lost in a vague, picturesque haze.

The student of light and shade will find the range of light is still a very wide one. The vivid glow of firelight, here flickering brightly, there vanishing in gloom, will always produce a striking effect. A pale splendour caressing the human form with vague reflections could be obtained by light streaming through stainedglass windows. The dazzling illumination of the hour of sunset, which pales and subdues all objects, and, concentrated on the human body, makes it look as if it had been absorbed all in light and radiated it (which Prudhon has attempted and Henner specialized), may fill our minds with new dreams of vision. Even the ghostlike rays of shimmering moonlight (as 
Steichen has shown in his versions of Rodin's Balzac), may open novel methods to render tone and form in the broadest and softest manner possible.

Still I do not believe in the garish effects of certain modern painters, who take special delight in reproducing the flaring vagaries of artificial light. The trend of such works is towards an affected æstheticism. They may be fascinating and "stunningly clever" but they do not ring true. They are at their best only in colour experiments specially made to startle the beholder. When Elsheimer painted his "Christ Taken Prisoner," showing the pale light of the moon in the background, while the nocturnal figures in the foreground are enveloped by the glare of torches, he ventured upon a problem that was, after all, logical and true to life. But to place a lamp on the floor merely for the purpose of throwing interesting diagonal shadows upwards on a woman's figure, is not far from being an absurdity.

The various aspects of electrical illumination, gaslight, flashlight effects, searchlight, etc., no doubt can be solved pictorially, but they should never be applied unless the character of the picture absolutely demands them.

Tone is the ideal of the modern painter. It 


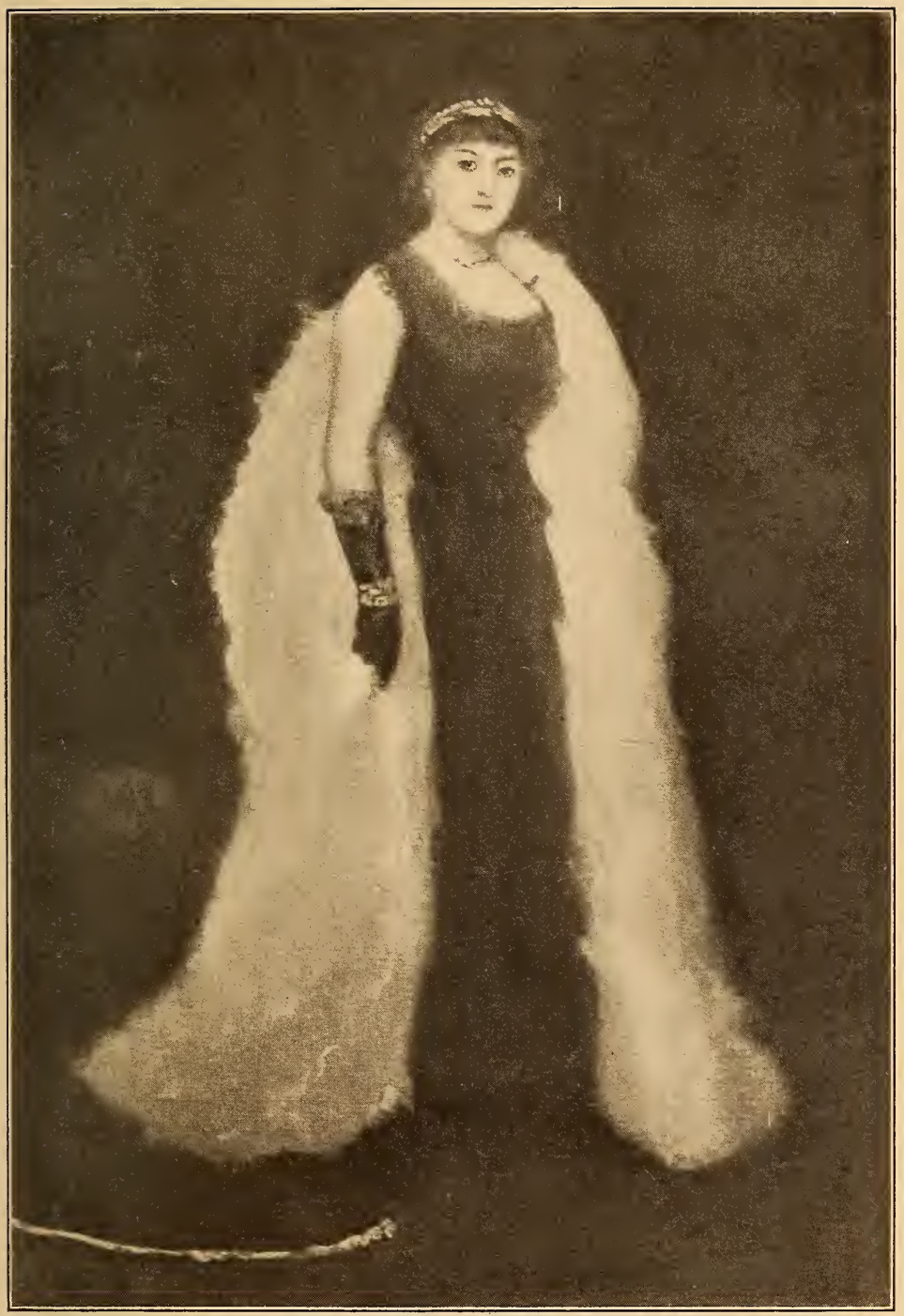

ARRANGeMENT IN BLACK AND White: LADY MEUX (NO. 1). 

is his highest ambition. It is the powerful subduer of all the incongruities of modern art.

But what painters strive for, in most instances are merely fragmentary accomplishments. It is not tone in the large sense as the Old Masters understood it. To Titian and Rembrandt and Velasquez "tone" meant a combination of all pictorial qualities, the contrast of colour, the balance of lighter and darker planes, the linear arrangement; all these together produced tone. They do not sacrifice form or detail, correct drawing, the physiognomy of the faces and the idea and conception of the picture to it.

Do not misunderstand me. Tone is desirable; no picture should be without it. But it is merely one of the elements that enter into the making of a picture, and not the whole thing. There are light tonalities as well as dark tonalities. A Renoir is as much in tone as a blackin-black Tissot.

What tonal painters see in tone is merely the appearance of old age. The Old Masters have become famous, and the public has acquired a certain predilection for dark-toned pictures. The modern painters try to reproduce it, overlooking (perhaps wilfully) that the dark tonality is entirely an artificial product, caused by dirt and dampness, the chemical 
action of light, and the gradual change of colour, oil and varnish.

The Old Masters painted in a low key, but they probably never thought that some day their pictures would look as they do now. The modern painters try to produce a quality that has nothing to do with art, they cater to the taste of certain art patrons that have a liking for old-looking things.

In portraiture the simplest scheme will always be most certain of success. Variety is desirable, but no exaggeration or strained effects. Of all modern painters Whistler and Carrière seem to have excelled in conquering the modern limitations of light and shade composition and making the most of them. They have enveloped their figures in clair-obscure that is uncertain in form, mystic in tendency, but suggestive of atmosphere, depth and space, some grey or dark interior filled with struggling shadows, capricious gleams of light and tonal gradations, tantalizing in their subtlety and power of suggestion.

All sharp lines are dissolved, each detail vanishes with soft delicacy into the other and their light, falling from some unknown source, quivers like a soft chord through the twilight.

The "Mother and Child" of Carrière has 


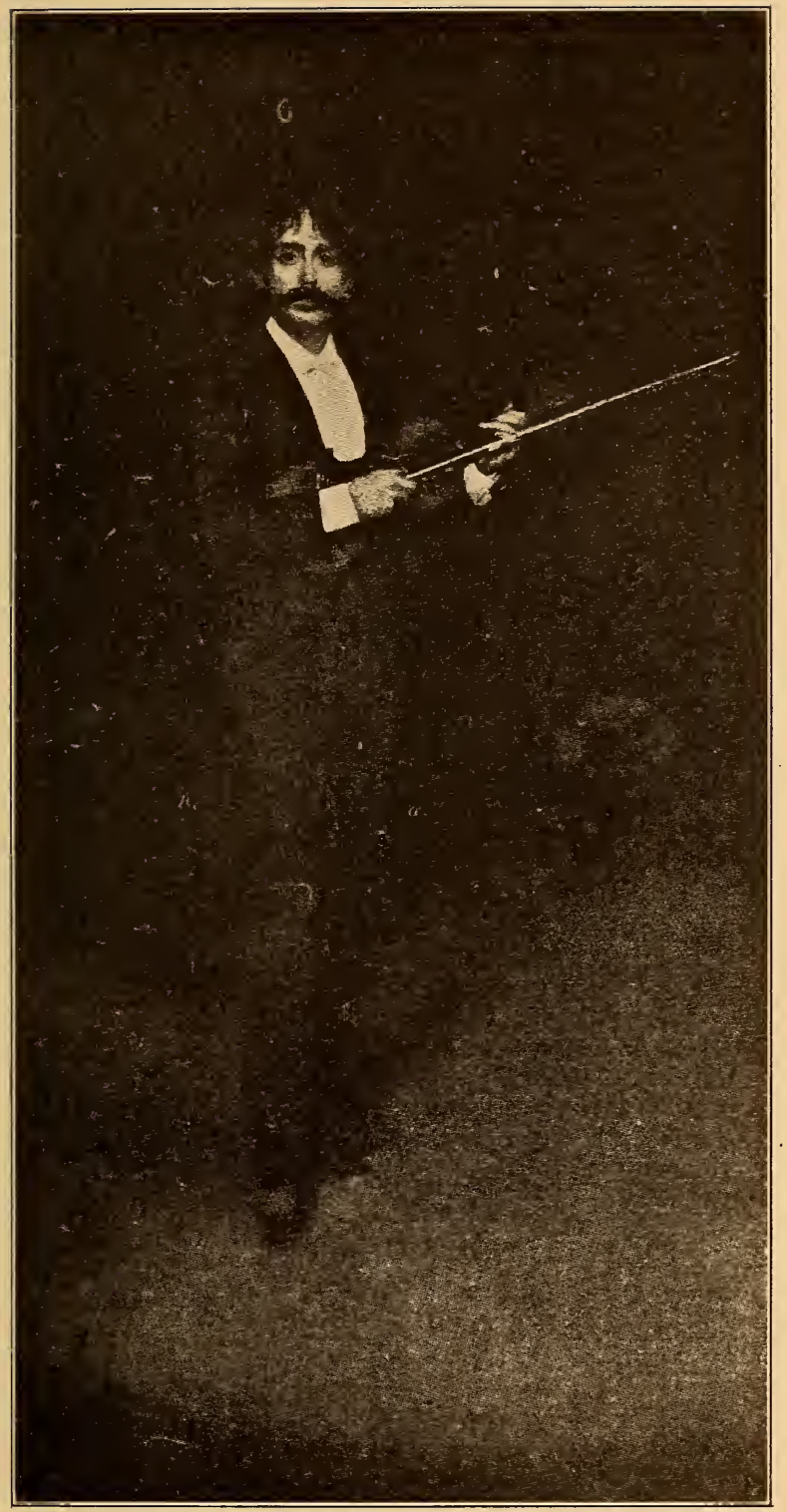

Carnegie Art Institute, Pittsburg

ARRANGEMENT IN BLACK: SENOR PABLO SARASATE. 
but little of the robust yet sweet and seductive charm of the Madonna pictures. Its glimmer of light is sad and dreamy, as if it were woven out of grey monotonies of everyday life. And in Whistler's "Sarasate" we see in the plastic, but solitary light passage, on face and shirt front a symbol of all the glamour of romance and poetry that light can yield in our prosaic age. Whistler translated all objects into flat surface planes, and, in that way, sacrificed more to the realization of tone than any other painter. His fragmentary visions are almost colourless but never give the impression of monochrome. Looking at one of his enigmatic figures receding into vague shadows, a strange association of thought occurs to me: I see in one of the sunless courtyards of the Escurial the dark figure of a woman standing near a fountain and holding a red rose in her hand. At one of the palace windows is seen the proud face of Velasquez, gazing absent-mindedly upon the scene. And the wind ruffles the flower, carries one petal after another and scatters them upon the surface of the water. Is this dark silent woman the personification of Whistler's muse, and does she tell us that the splendour of light and shade composition of the Old Masters has faded, that we know nothing of its fervour that rose from the depths of a 
more picturesque age, and that all we can do is to scatter a few colour notes across the darkness of space? For the jubilant and passionate note is altogether missing in Whistler's art, though it can claim profundity and some dreaminess.

Light now flits phantom-like across the masterpieces of pictorial delineation, but it is still the great elixir of art, that will give life to any scene and animate any object. No special method can be indicated. Every worker must be his own pioneer and pathfinder. The new era of light is yet in a primitive stage. It is a lonely art whose language is understood but by the few, though we have approached the hour of dawn before the awakening. Life may seem dreary and colourless to us, yet we should realize that only one beam of light is needed to change it into a vision of beauty.

To Rembrandt even the Bree-straat in Amsterdam, resplendent in his time of Oriental culture and Moorish pomp, may have seemed dull and colourless. He had to create for himself a distant and enchanted realm from out the prosaic world in which he lived. And so must every ambitious artist dream himself far away from the grey of everyday life and construct a poetic world for himself alone.

Light is, after all, objective and merely sug- 
gestive. The artist's mind must serve as some Faustean retort, which will turn these suggestions into the soft gleams and sparkling shimmers of art. Whistler was one of the few to accomplish the task. 


\section{CHAPTER VI}

\section{SYMPHONIES IN INTERIOR DECORATION}

William MorRIs demanded that our entire environment should be beautiful. Only in moments of superior enjoyment do we realize the significance of human life, and by a poem, picture or sonata we construct the symbols that bring us closest to this appreciation. Why then not construct a candlestick, a chair, the surface of a wall, in such a way that they might be taken for symbols, to remind us of the existence of our soul? The candlestick shall no longer be a mere stand and holder for a candle but a souvenir of reminiscences. That is the philosophical idea that underlies all interior decoration and furnishing.

As Sheridan Ford so aptly expressed it in an article in "St. Stephen's Review" in 1889:

"There are in England two new, and in their origin, distinct methods of interior decoration. Gradually they have coalesced to a degree, although they will always retain their individual traits and differences. These two 
Symphonies in Interior Decoration 101

methods may be termed the Whistlerian, and the English or pre-Raphaelite; the one, spontaneous, fresh - simple, the other, a revival complex — reformatory. Through many years, from the early days of the pre-Raphaelites down to the last meeting of the Paintersocialists, an outside influence - a personality - has been making itself felt in London in strange and subtle ways."

The Morris arts and crafts movement believes in patterned design and the dominant force of the material. Every material speaks its own language, and we must understand, before we can lend expression to it. When the actual moment of designing arrives, the artistartisan should work with a piece of the material itself before his eyes - wood, stone, iron or plain silk, linen or wool stuff, according to circumstances. This memory of nature's forms, dominated by the momentary impression of the material, with its requirements, capabilities and limitations, would lead him to a more congenial and workmanlike result than all the contents of a natural history museum, botanical garden or library. In the same way as we can give to words a dramatic, epic or lyrical significance, so has wood, leather and glass their own sphere of expression. Harmony in every detail is the ultimate result. A room is no museum, every 
object must be related to the other, the candlestick must make a rhyme with the wall-paper, with the woodwork, the hangings, the table and chairs.

Whistler, on the other hand, was the apostle of Japanese simplicity, of suggestion rather than realization. He tried to express his own æsthetic creed, and that consisted of restful expanses of unbroken wall, of decorative devices and ornamental motifs, individual caprices accentuated by black, and, finally, by colour. Colour in interior decoration meant to him the same thing as tone in painting. It reigned supreme. Our feeling of beauty varies; it may find its expression in a certain flower, a certain hour of the day or season, in a certain poem or song or, as it was the case with Whistler, in a certain delicate colour tint, that would make a room look gay and cheerful. He tried to bring the sun into the house, even in a land of fog and cloud. Pale pink, brown, pale turquoise, primrose, saffron, sulphure and lemon-yellow were his favourite colours. These he endeavoured to express. It was the gesture of his soul translated into every object and material.

A colour is like a special metric form, and all lines, and every combination of tint - the sofa, the lamp, wall-paper - take the place of 
Symphonies in Interior Decoration 103

stanzas in a finished poem. In such a house we would see mirrors everywhere reflecting our own personality. Such were Whistler's creations. They reflected his own face, and echoed his own song. Whistler arrived at these conclusions early in his life. During his StevensJapanese print period he interested himself a good deal with decorative schemes. He had painted " The Princess of the Porcelain Land," which was purely decorative, and, in a way, served as inspiration for the Peacock Room, as the design for the latter was really invented to find a proper environment for the painting.

In a diary of William Michael Rossetti, the ever busy biographers have found a note referring to six schemes or projects of practically the same size. It reads: "Whistler is doing on a large scale, for Leyland, the subject of women with flowers." They were never executed, although some of the sketches are still in existence. He abandoned decorative schemes entirely in later years, but became more and more engrossed in the problems of interior decoration. In later years he intended to paint a grand decoration with full orchestration that he would call "The Symphony of Colours Full Palette." This would have been indeed interesting, but I fear he went too deep into blacks to have accomplished it. In most in- 
stances he abstained from mural decoration, the panels over the chimney-place, and the shutter and ceiling decoration of the Peacock Room for the Leyland home at Prince's Gate, London, were his only supreme effort in that direction. They show the right idea about decorative painting. He agreed with all decorative painters from Gozzoli to Bob Chanler, that it should be an arrangement of colours which, within its frame, affords a pleasant visual entertainment.

There is no intention to give food for thought. The peacocks in blue on gold and gold on blue relate as little as does an Oriental carpet. He merely wished to please the eye by depicting them more beautifully than they were in nature. But why did he select peacocks? Do they not convey an idea? Figures usually are story-telling symbols, but not necessarily so; with him they were vehicles of colour, to invent a pattern for their luminosity. Peacock designs occur frequently in Japanese art. No doubt, Whistler studied them. There is a certain resemblance, but he individualized them in his own way. The sharply silhouetted forms of the birds are a happy invention of luminous colour and interesting design. The Japanese would have made a more lavish use of gold, that is they would have left larger 


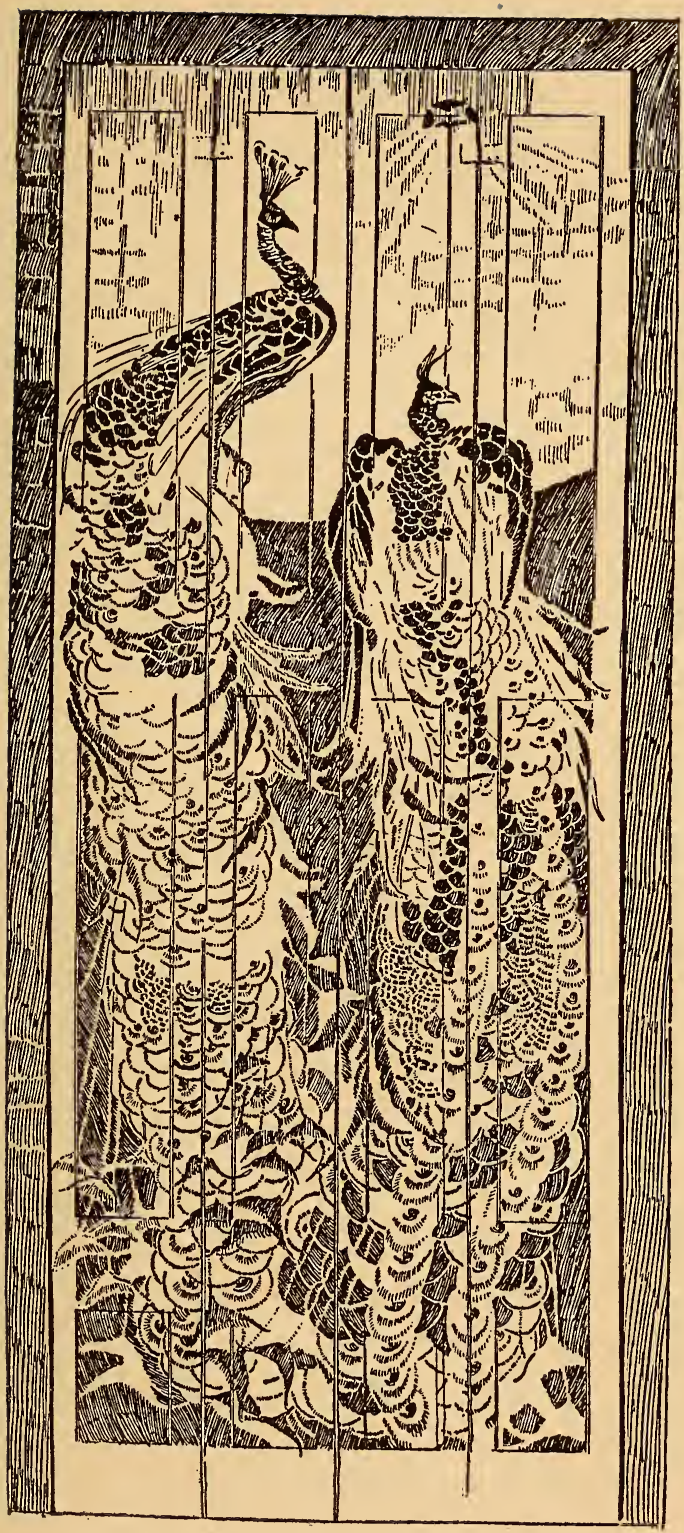

SHUTTER DECORATION, PEACOCK ROOM. 

Symphonies in Interior Decoration 105

spaces untouched by any additional colour. Blank spaces of gold (or any colour) act in such instances like the musical silence of a pause between music, they represent the birth of beauty from luxury. But the Leyland room was overcrowded, with its elaborate ceiling, bulky chandelier and collection of blue and white porcelain on walnut shelves, broken by an endless repetition of perpendicular lines. He could not change the architecture of the place, so he went to work and decorated the few spaces that were available. To decorate the inside shutters with a peacock design was a unique performance, and to cover the moulding of the chandelier and the entire ceiling with conventionalized peacock feathers, utilizing the eyes of the feathers as accents, was even more marvellous. In the elegance of its scheme, and its individual perfection, splendour and restfulness it has no equal.

When Whistler moved into houses of his own, he had, like all ambitious house-owners, the desire to create a comfortable and beautiful home. None of his houses were ever completely decorated and finished; they had a look, as Pennell tells us, as if he had just moved in, or was just moving out; often there were packing cases and trunks about, but as much as was finished was always beautiful. 
The "House Beautiful" or "White House," was a three-storied house with many windows of various sizes, a green slate roof, bluish-grey door, Portland stone facings and fantastic wood ornamentation. A queer looking house, was the verdict of the neighbours, and yet it was rather unassuming, so that it escaped the attention of the ordinary passer-by. While various schemes for each room were in his mind, a friend, Mr. Sutherland, director of the P. O. Company, called one evening in the spring of 1873 to ask Whistler if he would help him in the decoration of his home. Whistler entered upon the idea with enthusiasm and prepared the plans. The novelty of the schemes was first approved of, but, as they developed, Mr. Sutherland began to doubt their plausibility. Whistler relieved him from all obligations, and determined that he would use the ideas in his own home. He went at once to work and three weeks later gave a dinner to celebrate the event. It was a revelation of simple delicate colour schemes - everything was artistic from the mahogany woodwork in the "gold and yellow" room down to the single flower in some bit of Kaga porcelain. In the room everything was yellow, gold or brown. The walls were tinted yellow, the cabinet and chimney-piece in one structure were 
Symphonies in Interior Decoration 107

of a bright yellow mahogany, with gilt panels. The tiles before it were of a pale sulphur colour. In some niches there was a display of orange coloured vases. The peacock designs were seen in some panels, but they were carried out in yellow and gold. The chairs were covered with yellow velvet, the table had brass legs and rested on a brown rug.

One may say that Whistler established three simple rules for decoration, which interpreted in words, might read like this:

First: That a house should be a dainty and complete thing - from the door-knocker to the ridge tile.

Second: That each room should be restful, with ceiling, walls and floors so treated as to give a sense of shelter, freedom and completeness, terminating in the floor at the base.

Third: that pure, tender colours scientifically used give ease and infinite suggestion, and should be allowed to play about a room without coming into boisterous contact with another.

Harper Pennington, a friend of Whistler's, has given a humourous but sympathetic description of the "White House:" "His furniture was limited to the barest necessities, and, frequently, too few of those. Indeed, some wit made what he called his "standing joke" 
about poor Jimmy's dearth of seats. Once Dick (Corney) Grain said, when shaking hands before a Sunday luncheon, " Ah! Jimmy, glad to see you playing before such a full house!" glaring around the studio with his large protruding eyes in search of something to sit on. "What do you mean?" said Whistler. "Standing room only," replied the actor. The studio could boast of only four or five small cane-seated chairs (always requisitioned for the dining room on Sundays), and the most uncomfortable bamboo sofa ever made. Nobody, except some luckless model, sat upon it twice. Never a book or any instrument of music in his room, nothing that would not constantly be in use, nothing superfluous; all his cares were centred on the wall and woodwork, painted in graduated monochromes, of which he held the secret.

The strangest thing about these rooms of his was, that they always looked complete. There was no space, apparently, for more than he put in them. So great was the art in his arrangements of colour and a few pieces of ordinary furniture - a spindle-legged table and three or four small painted chairs - that it seemed impossible to add so much as a book without disturbing the harmonious whole. Curtains, a little mirror, one, two, three at the most, per- 


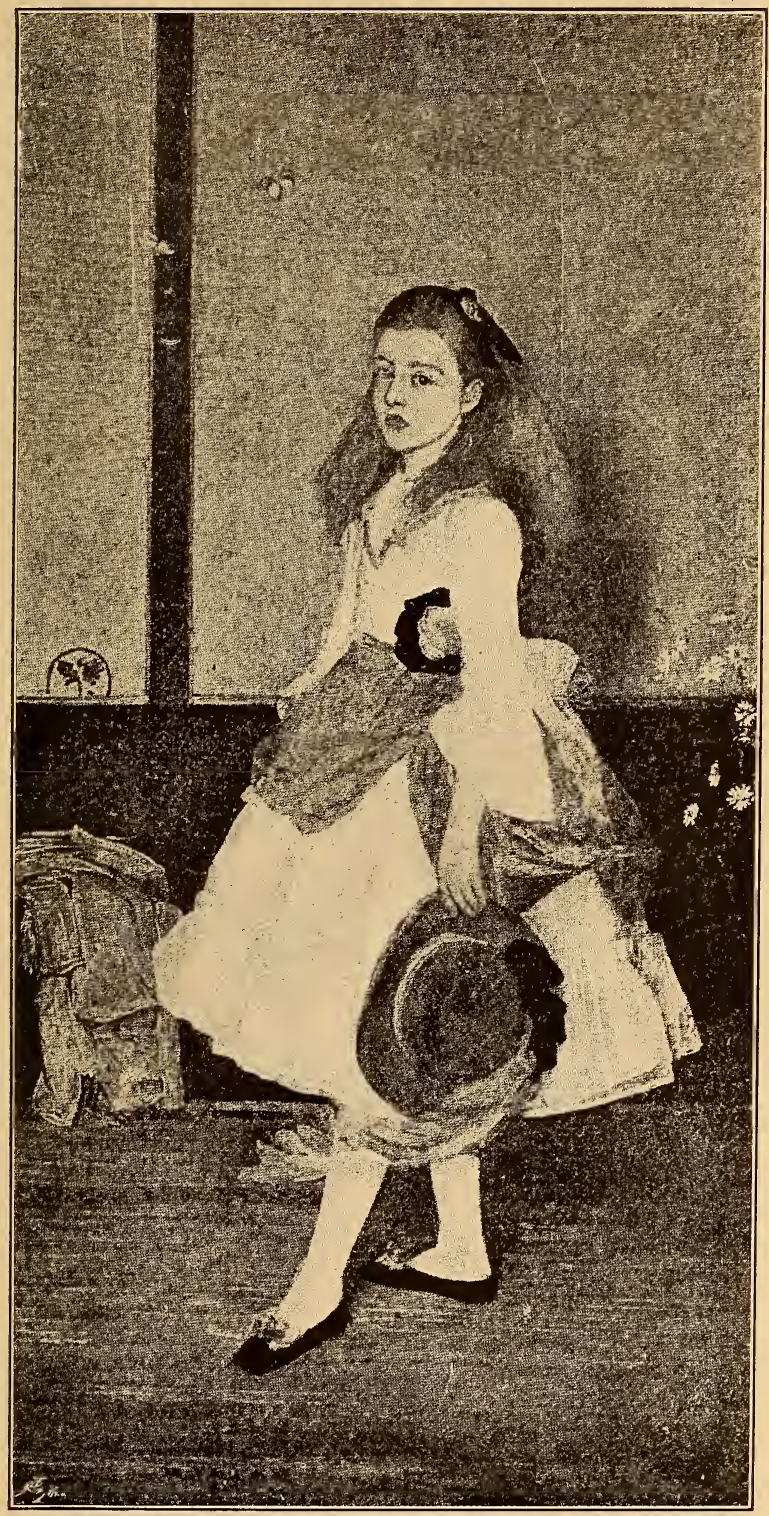

ARRANGEMENT IN GRAY AND GREEN: MISS ALEXANDER. 

Symphonies in Interior Decoration 109

fectly placed pictures, a vase, perhaps a pair of them, upon the mantel, and matting on the floor, were literally all that any room I ever knew him to occupy appeared able to contain. There was a sense of finish and finality about it which a piano and stuffed furniture would have disturbed. In the vases, as in two square hanging pots upon the wall of the dining-room, there were always a few yellow flowers, and in a huge old china bowl, that formed the centrepiece of the dining-room table, swam some tiny gold fish - the whole thing was carefully composed so as to make the "symphony" complete at those historic Sunday breakfasts.

His various abodes became a topic of conversation, and a place of pilgrimage, and made Whistler, for a while at least, a recognized leader in decoration. He developed a style, the influence of which has been felt all over Europe. The beauty of one colour in the decoration of a room, the division of space into simple lines and masses, the scarcity of furniture, leaving large empty spaces, the use of flowers or a few choice pieces of bric-a-brac, we owe largely to Whistler. The backgrounds of his "Miss Alexander," "Carlyle" and "The Artist's Mother" offer vague glimpses into the realm of individualized decoration, and, in a way, 
better information about its character than a hundred pages of explanation.

Among the houses that were decorated under Whistler's supervision are the Aubrey house, Kensington; Carlyle cottage, Chelsea; the home of Mr. D'Oyle Carte, on the banks of the Thames, the music room of Sarasate in Paris, for whom it is said, he also designed the furniture, and the "Pink Palace," where he lived with his favourite model "Maud," in 1885.

Occasionally he may have designed the furniture as a particular favour to a friend, but it was not his habit. All he did was to give advice or to make the selection. Now and then he may have made a hasty sketch to make his idea clear to others, but it is not known that he ever made a regular design that could have been used by a skilful cabinet-maker to work from. He merely suggested, and, if conditions allowed, to establish beauty of proportions. Beauty of design should exist, no matter whether it be in the vault of the Sistine Chapel, or a writing desk, but colour is imperative. His "style" consisted of little more than selecting a special colour scheme. He took pride in mixing the colours, but never put them on himself. An ordinary house-painter served the purpose just as well. He looked at a room, 
Symphonies in Interior Decoration 111

decided what parts should be dark or black, and then proceeded, in his most scientific manner, to find a colour, delicate and luminous, that would brighten the walls. No doubt, he laboured under favourable conditions. But we should not forget that he himself created these conditions, in which his artistic personality perhaps found its happiest and most characteristic expression.

Exquisite colour and simplicity and the desire to gain the possible effects of light were the leading characteristics of the Whistler style. Whistler committed one great error. $\mathrm{He}$ invariably preferred beauty to comfort. He frequently lost sight of the practical, with the result that use and beauty were not always combined in due proportion. He had little regard for physical requirements - he himself was always active, he had no time to lounge, consequently decorative possibilities alone interested him. It is the same trouble with $L^{\prime} A r t$ Nouveau. Although infinitely superior to the soulless copyism of different styles as practised by sterling bronze and artistic furniture companies, it lacks that true artistic feeling for ornamentation, which makes the designer at once realize the proper limits of his materials and show proper judgment in the uses to which he puts them. Whistler was so sen- 
sitive to any discord of line or colour, that he, no doubt, would have endured inconvenience rather than have destroyed the harmony of an effect. Most of us do not care to exist that way.

A house is built to live in, with as much grace as possible, but primarily with a feeling of comfort. Most people would prefer a modern apartment to an old palace at Fiesole. The material demands of the owner should determine the construction of the house. The American architects begin to realize this more and more. What principle rules the construction of a window? The dimensions of the room. The windows are not made for the street, to be looked at from the outside; they are there for the room, to distribute light and emphasize any special use they may be put to. In a parlour, for instance, people are more apt to look out a window than anywhere else; for that reason the parlour windows should be wider than in other rooms to enable several people to look out comfortably at the same time.

A chair is made to sit upon comfortably, not merely to look beautiful. The most beautiful design in a chair will not condone the torture that may be caused by a shape that does not adapt itself to the human form. The 
Symphonies in Interior Decoration 113

chairs in the Sarasate music room were exquisite but too stiff to allow any repose. Imagine listening to a concert sitting erect, without being able to stretch out one's limbs. The main reason for not having any comfortable chairs in his own studio was one of self-protection. It was his work-room, and he wished to prevent visitors from making it a hall of gossip. He preferred to have it empty; a promenade to contemplate the next master stroke on one of his paintings.

When Whistler was forced to give up the "White House," and all its beautiful contents were dispersed, he was enraged that the succeeding owner, “ Arry " Quilter, took liberties with the façade. Quilter had added a bay window, and, to Whistler's idea, destroyed the entire effect. After that he never wanted to look at it again. On one occasion he expressed his anger in a most amusing manner. "To think of Arry living in the temple I created," he said. "He has no use for it. If he had any feeling for the symmetry of things he would come to me and say: 'Here, Whistler, is your house, take it, you know. its meaning, I don't. Take it and live in it. - But no, he has not sense enough to see that.",

Harry Quilter, no doubt, got as much enjoyment out of the house as Whistler did, although 
in a different way. Extreme sensitiveness in regard to line, colour and form produces a beautiful result, not unlike a handsome painting, but I fear it would prove monotonous in the long run. A beautiful room is like a simple melody, but if the melody has any striking individuality, we soon tire of it. If the decoration could be kept entirely neutral the problem could be solved satisfactorily. But pink and lemon-yellow are not neutral. Not everybody would feel happy in a blue room decorated with purple fans. Even a woman in a certain gown would destroy the harmony, and a definite colour seen all the time, even if unconsciously, would soon disturb our mental serenity. The Whistler rooms were beautiful when no human being moved in them. They were there for the photographer, but not for congenial habitation.

I believe most people will agree that the most beautiful bed is the one in which one can sleep most peacefully; the most beautiful chair the one which allows perfect relaxation of the body; the most beautiful glass that which lends itself most gracefully to convey to our lips the special beverage it is intended for. This may sound unæsthetic, but it is common sense. Comfort comes first, whenever ordinary living purposes are concerned. There is plenty of opportunity 


\section{Symphonies in Interior Decoration 115}

for the exploration and exfoliation of beauty, but it should be subordinated to the primary causes.

Whistler's influence, in my opinion, was most beneficial in the arrangement of exhibitions. An exhibition of paintings, or any work of art, is solely an æsthetic venture, and should be harmonious at any cost. It is just in this that most exhibitions fail. They show the most incongruous backgrounds, frames of the most incredible malformations, floors that are either bare or loudly carpeted and pictures that are hung without the slightest consideration for their colour values. With the simple use of distemper, matting and muslin Whistler performed wonders. During his short reign as president of the Society of British Artists he transformed the Suffolk Street galleries from a barn into a dignified exhibition hall. Pictures, frames, walls, floors, lighting and decorations, each element had its due place, the one supplementing the other, and harmonizing, instead of conflicting with it, as is so often the case.

Every year saw some fresh assertions of his leadership. He took a great deal of interest in the arrangement of his own exhibitions, making some of them occasions for the exploitation of his views in new and original ways. 
His initial exhibition in Pall Mall, 1874, where, for the first time, walls were brought into harmony with the pictures upon them, and successes in Bond Street, at the Fine Arts Society, and at Dowdswell's, are accepted facts in the art history of London. Each one of these exhibitions especially embodied the demonstration of a colour scheme or problem of decoration. So there came to pass, in their turn, the arrangement in "Flesh Colour and Grey," the harmony in "Gold and Brown" and the arrangement in "Yellow and White," and others, equally characteristic and original.

With scrupulous love of detail, he neglected nothing and devoted unusual attention to the make-up of the catalogue. The brown-covered paper catalogue of the exhibition of etchings held at the Fine Art Society Gallery, in 1883, was issued with the imprint of the artist's home in Tite Street, Chelsea, and represented his peculiar views of typography as well as the art of slaying incompetent and hostile reviewers with their own weapons. After the title of each etching was printed a quotation from some criticism, under the general motto (on the title page) "Out of Their Own Mouths Ye Shall Judge Them."

"Prodigious amateur - there are years when Mr. Whistler gives great promise - In 
Symphonies in Interior Decoration 117

this instance criticism is powerless-Mr. Whistler is eminently vulgar - General absence of tone - Mr. Whistler has produced too much for his reputation " - are some of the quotations. The Gallery, on this occasion, was hung with white and yellow, had yellow matting on the floor, yellow chairs and yellow flower pots. The attendants at the door were in yellow and white livery, while the artist wore yellow socks, and his assistants yellow cravats.

For the catalogue of the exhibition of paintings held in 1884, Whistler prepared a page of " propositions" called "L'Envoie," which we quote elsewhere, and he repeated in the catalogue of "his heroic kick in Bond Street" in 1892, the use of quotations from the critics, for each title entry. The mottoes on this occasion were: "The Voice of a People" and a sentence from the speech of the General Attorney at the Whistler v. Ruskin trial, "I do not know when so much amusement has been offered to the British public as by Mr. Whistler's pictures." The artist triumphed, the success of the exhibition proved the futility of the early judgments. A perusal of this queer document, even to-day, elicits a smile; it is delicious humour and at the same time a splendid assertion of artistic power and self-adulation.

The first New York exhibition of work by 
Whistler was held in the old Wunderlich Gallery, on Broadway, in March, 1889, when sixty-two "Notes," "Harmonies" and "Nocturnes" were shown, with some accessories of yellow hangings, flowers, furniture and footmen imitation of the London exhibition of 1883. But this sort of thing is rarely successful in this country. It is apt to be misinterpreted, and somehow looks out of place.

One of the finest achievements of the painter is the frame which rightly bears his name. The official exhibitions still insist on the usual monotony of gilt frames, and the painters seem to have neither any particular inclination nor the opportunity to create frames of lovely forms and well-balanced repeating patterns of their own. The frame-makers and art-dealers are masters of the situation, and their interests are strictly mercenary ones.

"Attractive enough at first sight, hopelessly inartistic on further inspection," is the verdict which one has to give of the average frame of to-day. Only a few of our painters oppose the mechanically manufactured frames. They have their frames specially designed for each picture, Stanford White having been the designer of quite a number of them. Their frames are wide and flat, without corners and centrepieces, the repeating pattern is generally a simple, 


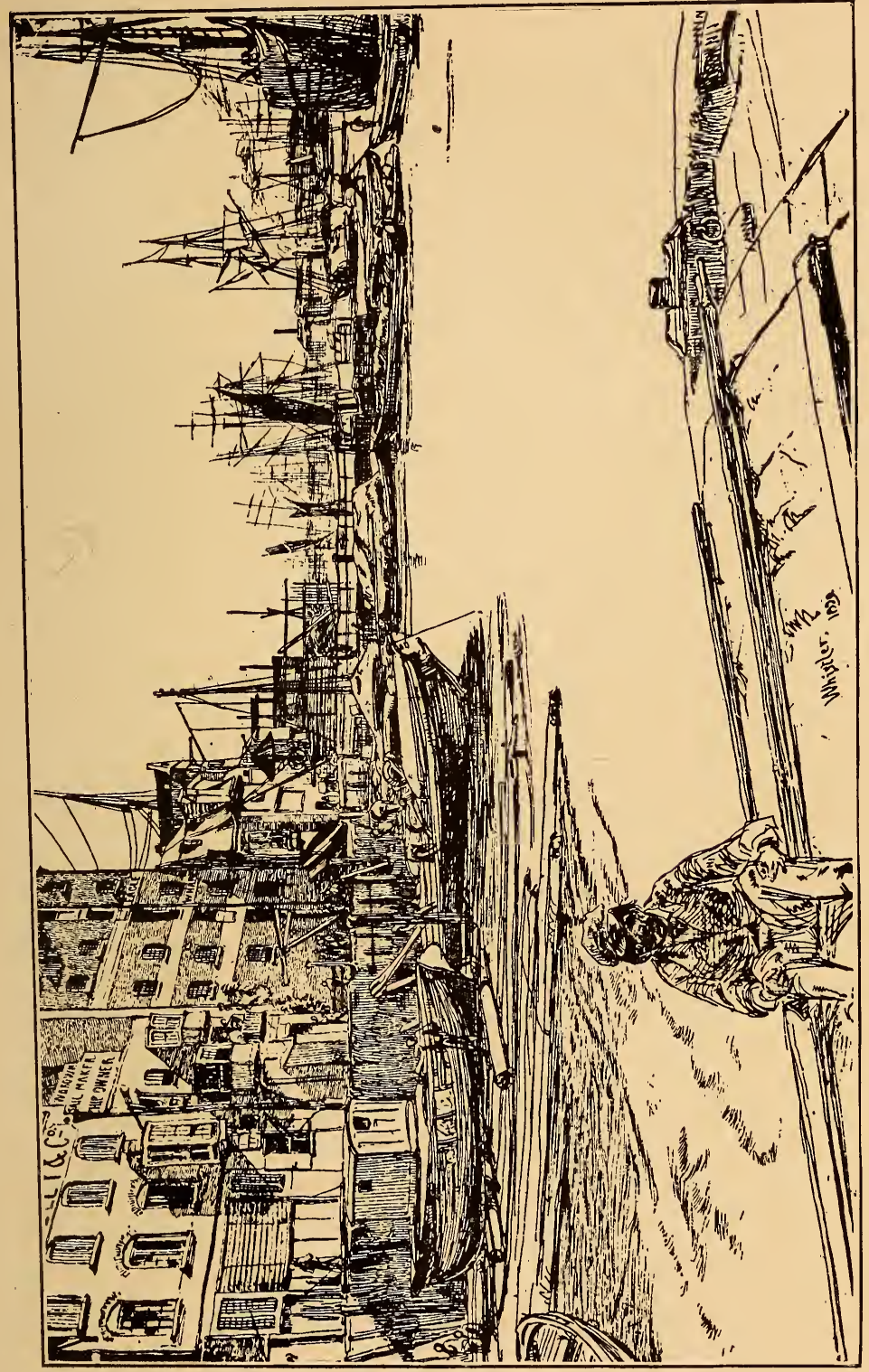

它 

Symphonies in Interior Decoration 119

classic ornament, with a tendency toward parallel lines. The architectural designs, with Greek columns in the upright sides, are rather heavy and less recommendable. Whistler's frames, which served as inspiration to all these later-day designers, were conceived in simple planes, broken with parallel grooves that were restful to the eye as sole ornamentation. They were original inventions, free from any taint of imitation. The gaudy burnished gold effect was substituted by pale gold and bronze that could be tinted and glazed according to the principal colour note of the pictures the frame was designed for. They are so simple that it is difficult to improve their design. But he did not make them for general use, he merely suggested to other painters the advantageousness of designing their own frames, as is now largely customary.

Whistler has performed a brave deed. If he had done nothing else but to improve our taste in the arrangement of exhibitions he would be remembered for many years. $\mathrm{He}$ has done far more. He has set up the big ideal of simplicity. His eccentricities and harmonies of decoration may not live. There are many men working on the same problem all over the Western hemisphere, and his peculiar style will undergo many modifications and improve- 
ments, but we should never forget that he was one of the first who opened our eyes to a practicable and inexpensive way of beautifying our home and everyday life. 


\section{CHAPTER VII}

\section{VISIONS AND IDENTIFICATIONS}

Azthough remarkably sure, efficient and successful in various branches of art, Whistler has to be ranked primarily as a figure painter. In these efforts centre his greatness. $\mathrm{He}$ is, however, only a figure painter in a modified sense. We look in vain for large and elaborate compositions. He achieved his fame as a portrait and single figure painter.

It is strange that a man who had the science of painting at his finger ends should limit himself to single figures. Perhaps he knew his limitations, or, the limitation of his peculiar view-point as to what painting should be and could accomplish. Possibly he went too far in his elimination. Who can say? An artist must be true to his own convictions, and the public and critics must accept, and, in time, learn to appreciate them. Analysis of an artist's work is interesting only as far as it helps one to find the right view-point for contemplation. 
Whistler, of course, had no use for ordinary portraiture, as it has been practised for centuries. He felt, no doubt, that the time for idealization as well as realistic interpretation of likenesses had passed. No painter can surpass Van Dyke in the elegant delineation of men and women, or Franz Hals in the representation of instantaneous expression. Whistler wanted a characteristic attitude that expressed in a simple pose or movement an entire personality. But the purely technical problem fascinated him even more, to express himself forcefully in black and dull colours, to paint broadly and yet so delicately that no brushwork became visible, and to create the illusion of atmosphere and space around the human form.

His first picture of importance (started in 1859), "At the Piano," was also the first true Whistler, not only the Whistler we admire and cherish to-day but the Whistler who has exercised an influence on modern painting and who will live as one of the prominent figures in the history of art. I have rarely seen a modern interior treated with more charm and simplicity. A woman, apparently Lady Haden, in a quaint black old-fashioned gown, is seated at the piano, from which she seems to elicit some vague melancholy chords, while a little 


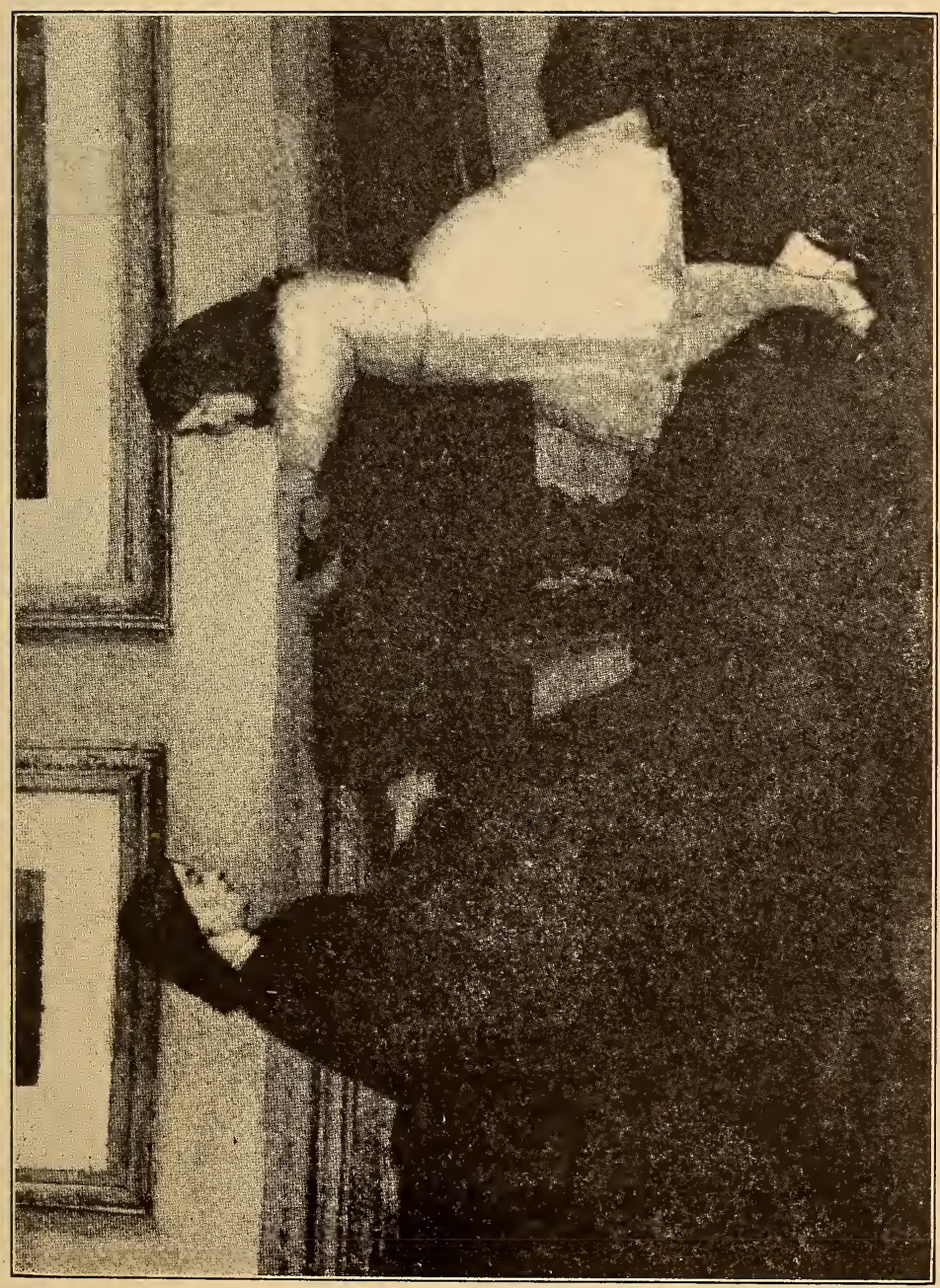

完 

girl in white, in a pensive attitude, stands opposite her, in the curve of the instrument. The dark silhouette of the mother is beautifully balanced by the white form of the little girl. There is an astonishing number of horizontal lines in the composition, but somehow they are not noticed, at least they do not offend the eye. I believe the diagonal tendency of the figures counteracts all other lines. One peculiarity of Whistler's interiors and backgrounds is that they nearly always represent a straight wall. He rarely indulged in perspective arrangements. His aim was breadth and simplicity, and he avoided all cheap pictorial effect. Technically, it still shows the Stevens' influence - it could almost pass for a genre picture - but in poetical conception and the suggestion of a mystic atmosphere it already predicts all the accomplishments of the artist's prime.

In his earlier career Whistler occasionally made use of more elaborate accessories, as in his "Little White Girl," "The Princess of the Porcelain Land," and the "Woman in White." The latter I consider one of his weakest compositions. The figure is rather stiff and too high up in the picture. The carpeted floor looks as though it were sloping. The bottom of the dress is too distinct. The 
same could be said of the entire contour, the lines are not sufficiently graceful to permit such clearness of line. Also as a painting of a white figure on a white background it is not unsurpassed. "Katherine Emmerich," by Gabriel Max, at the Pinakothek, Munich, and the Raffaelli's "Sleeping Woman," in the Wilstach Gallery, Philadelphia, treat the same theme but are technically superior.

Whistler developed slowly. Only gradually he learned to avoid detail as much as possible, and only occasionally accentuated it here and there, as a note of contrast to the larger planes. The years 1870-90 were the most active and important years of his career. Nearly all his portraits, those of Frederick Leyland, Florence Leyland, Miss Alexander, Rose Corder, Sarasate, Sir Henry Irving as Philip II, The Fur Jacket, Lady Archibald Campbell, The Artist's Mother, Carlyle, Theodore Duret, Mme. Cassatt, Mrs. Huth, Lady Meux, etc., were painted in that period.

All these later pictures were painted under the ban of Velasquez. In Whistler's paintings Velasquez's art was revived and rejuvenated. $\mathrm{He}$ repeats the same inspirations but in an etherealized, modernized and individualized manner. Whistler was triumphantly himself. 
There is much conjecture as to how Whistler acquired his knowledge of Velasquez. Joseph Pennell claims that Whistler never went to the Prado in Madrid. Duret tells us, that during a trip to Spain in 1882, he intended to go to Madrid, but on the way was fascinated by the scenery around Guethary (north of Biarritz) to such an extent that he prolonged his stay until it was time to return, without having crossed the Pyrenees. Others, with a quizzical mien, say that he might have gone without letting anybody know of it. It is hardly credible that he did not see the "Dwarfs," the "Spinners," the "Mercury and Argus," the "Maria Theresa," "La Meninas," "Esop," the "Menippus" and the "Surrender of Breda."

However it really matters little. $\mathrm{He}$ had seen the portraits of the Hermitage at an early age, and was thoroughly acquainted with the various portraits of Philip II at the London National Gallery. In this age of handbooks one can study Gozzoli in a New York garret. Of course a trip to Florence might prove profitable, but the right man, with the proper amount of imagination, knows no obstacle. His intuition will help him to get thoroughly imbued with any subject he is bent upon knowing. 
The portraits are all single figure studies, with a plain or simple background. They do nothing. They merely convey the charm of a personality as seen in an arrangement of colour. Whistler was a keen observer of facial expression and gesticulation and still more so of that other no less telling kind of expression, which depends upon our general bearing, and upon the way we move our limbs and body while we are trying to convey our thoughts and intentions to our neighbours. But this was not the principal theme, as it is of so many portrait painters. To him the very soul of art was elimination: to leave out all that could be left out. He realized that he could not proceed in the elimination process as gaily and liberally as in his nocturnes. He needed a more convincing sense of form, a certain regard for detail - no matter how broadly rendered - and a feeling for accurate line. This fragmentary representation of a human being requires the keenest artistic feeling, to know exactly when one has to stop in the process of reducing the multiplicity of nature to simple forms, of discarding superficial traits of the figure and retaining only the essential ones. For elimination is only half the game; selection makes up the rest. The sureness with which Whistler stops just upon the bor- 
der line proves his genius. However vague and enveloped his line may have become, it has never been pushed beyond the point where it falls into meaningless and spiritless formlessness.

Whistler's portraiture may be summed up as a never-ceasing study to express a human personality in the subtlest way imaginable. At bottom of all that he creates, there lies the desire to make his figures betray their character, emotions, and their whole personality by means of a tonal vision.

In the portrait of Frederick Leyland, the "Medici of Liverpool" (painted 1873), Whistler, for the first time, introduced the plain background without accessories, endeavouring to subordinate it to the figure. In the portrait the figure occupies the entire length of the canvas, and yet is enveloped in atmosphere. I believe this is largely due to the vagueness of outline and the accentuation of the principal points of the human form by touches of light, as the headlights on the silver buckle of the shoe, the hand on the hip and the gray overcoat over the left arm. The blacks in this picture have a marvellous quality. The painting of a black evening suit against a pitch black background is one of the masterpieces of modern technique, over which future 
ages will not cease to marvel. Also the shadow on the grey floor helps. The pose is dignity itself, but it seems to me that the artist did not quite succeed in carrying out his own ideal. The figure makes the impression as if it were stepping out of the picture, like a Rubens.

The same problem occupied him for years. $\mathrm{He}$ succeeded much better in the "Rose Corder" and "The Fur Jacket;" and in the "Lady Archibald Campbell," also called the "Yellow Buskin," he actually solved the problem. The picture is at the Wilstach Gallery, Philadelphia, and everybody who has seen it will realize, or feel, at least, that the figure is represented as if actually moving in space.

Most of his pictures were painted in ordinary rooms, without a top light, partly, no doubt, because he wanted to paint his sitters under natural, not artificial conditions. Also the "Rose Corder" portrait, painted in 1876, carries out this sensation. This portrait, which was purchased by Richard A. Canfield.from its former owner, Graham Robertson, is entitled "An Arrangement in Black and Brown." The differentiation of brown in the hair, fur, felt hat, feather and floor are so subtle and beautiful, that it would be almost impossible to go any further in the exploita- 


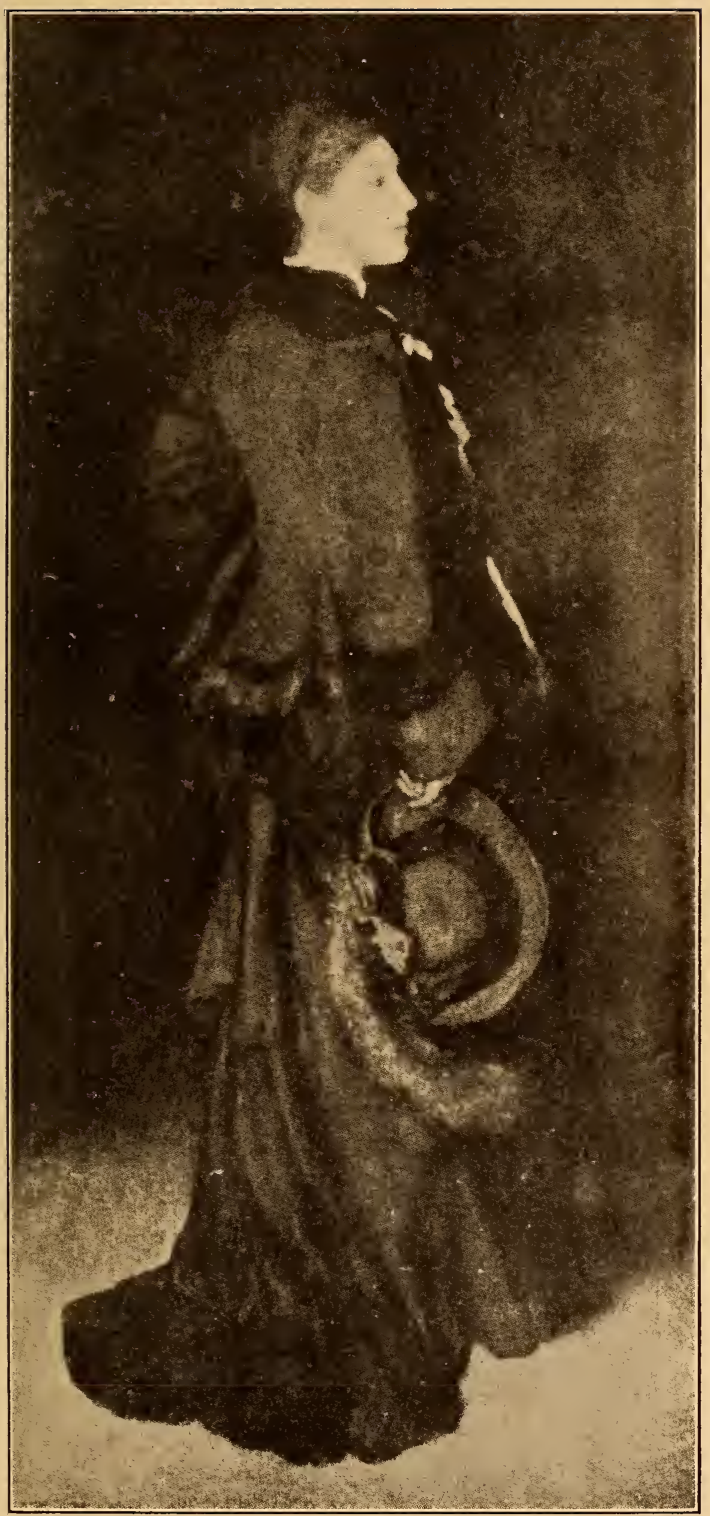

Owned by Richard A. Canfield

ARRANGEMENT IN BLACK AND BROWN: MISS ROSE CORDER. 

tion of one colour. The person who can appreciate the subtleties of these cool, almost neutral colours, appreciates Whistler. It was his main ambition, even to that extent that he wished the beholder to know of his intention. And that is no doubt the main reason why he called his portraits "Arrangements and Harmonies," even as other artists call their portraits "Interpretations," and their sculptured busts "Versions." Titles are really of no importance. They are, at the best, only annotations, but, as long as they are deemed necessary, they ought to give a vague suggestion of the subject matter or reveal the technical aim of the painter. Whistler's titles are frequently too long, but they generally convey some direct and valuable information to the beholder.

The "Florence Leyland" portrait, painted in 1873 - at The Brooklyn Museum of Art and Sciences, - is also much liked by painters. It always seemed to me a trifle dismal in tone. The greys have a muddy look and the background is too black and opaque. It is a study in greys and blacks. The dress, the floor, and the feather of the hat are grey. The hat itself, the gloves and the bow are black. Even the handkerchief and the white ruffles that fall over the gloves are grey. The design is ele- 
gant and visible, but swallowed up in the colour. Its success or failure depends upon your psychological appreciation of colours. If you like that particular combination you will admire the picture, and otherwise you will not, and no argument will persuade you to accept it as a masterpiece.

Whistler's unusually low key in the majority of his portraits strikes us as peculiar, even to this day. There are no gold, rose and mauve flesh tints of a Titian to be found on his canvases. "There is no bloom of flesh which emulates the gleam of a pearl or the luminous grain of a camelia." But the faultfinding is largely the effect of our being accustomed to high-keyed portraiture. Whistler explained this, in his drastic manner, in an article in the London World, July, 1886, which we quote in full:

" The notion that I paint flesh lower in tone than it is in nature is entirely based upon the popular superstition as to what flesh really is - when seen on canvas; for the people never look at nature with any sense of pictorial appearance - for which reason-by the way - they also never look at a picture with any sense of nature, but unconsciously from habit, with reference to what they see in other pictures. 
"Now in the usual "picture of the year" there is but one flesh that should do service under all circumstances, whether the person painted be in the soft light of the room or in the glare of the open. The one aim of this unsuspecting painter is to make his man stand out from the frame - never doubting that on the contrary, he should really, and in truth absolutely does, stand within the frame - and at a depth behind it equal to the distance at which the painter sees his model, and nothing could be more offensively inartistic than this brutal attempt to thrust the model on the hitherside of this window. Lights have been heightened, until the white of the tube alone remains - shadows have been deepened until black alone is left. Scarcely a feature stays in its place, so fierce is its intention of ' firmly' coming forth; and in the midst of this unseemly struggle for prominence, the gentle truth has but a sorry chance, falling flat and flavourless and without force. Whereas, could the people be induced to turn their eyes but for a moment, with the fresh power of comparison, upon their fellow creatures as they pass in the gallery, they might be made dimly to perceive, though I doubt it, so blind is their belief in the bad, how little they resemble the impudent images on the 
wall! how 'quiet' in colour they are, how grey and low in tone. And then it might be explained to their riveted intelligence how they had mistaken meretriciousness for mastery and by what methods the imposture had been practised upon them."

People on the whole prefer brightness to æsthetic gloom, and refuse to accept the unadulterated truth. "A beautiful picture! But I would not like to see my wife or mother painted that way," is the general verdict at a Whistler exhibition. And it includes people who should know better. Do not even learned critics excuse the low-keyed, ash grey tints of Velasquez faces by asserting that he wished to symbolize the doom of Spanish feudalism by their paleness? Ridiculous! A proud Spanish cavalier himself, such a thought would never have entered his head. He painted them with a bloodless enervated complexion, because they had that kind of complexion and because he, as a realistic painter, objected to any idealizing process.

It can, however, be safely stated that Whistler frequently went too far in his search for dark tonalities. But there was a reason for it. No primary colour is agreeable with black. If black is the favourite colour he must exclude yellow, red, and blue or paint them 
exceedingly low as Tissot has done in his "Prodigal Son" series. Yellow is the easiest colour to manage, as black impoverishes its tone. The secondary colours, like orange, green, and violet, lend themselves more readily to any scheme where black furnishes the prominent note, but they must be dull, obscure and possess no brilliancy. White, on the other hand, as Whistler so fully realized in his "Lady Meux, No. I," will always produce by its extreme difference a harmony of contrast.

The most suitable colours for a combination with black are the neutral colours, like grey and brown, or delicate tints, like pink and olive, russet and citrine. At these conclusions every student of the harmony and contrasts of colour must naturally arrive. And Whistler conquered his knowledge by actual experiments. It was no whim. As long as he favoured black he could not change his colour schemes. His colouring had to be kept cool and the few tones of luminous colours that he introduced had to be broken and neutralized. The scientific facts underlying his colour moods should answer all futile questions of why he selected such deep and sombre colour combinations. We all realize that he is no colourist in the sense of Memling, Pinturicchio, Titian, Rubens, Fragonard, Dela- 
croix, Makart or Roybet, he does not even show us as much variety as Constable or Israels or an Impressionist.

I say Impressionist, because an Impressionist's canvas can be deprived of colour (and how many are) as much as any black-in-black arrangement of a Tissot or Ribot. The high key does not save a picture from being colourless. Colour means the full use of the palette, green, blue, red, and yellow, on one canvas as distinct sensations and not modified into a general tint. The majority of Impressionists are tonalists not colourists. Franz Hals and Velasquez were fond of black and greys but rarely lacked the sense of conveying a delicate colour impression. Whistler, who, in his portraits is a great tonalist but never a colourist, displays the same faculty in his best work, but in some instances his subtle touch seems to have forsaken him, and the result was a dull tonality as in his "Florence Leyland." A similar colour scheme but of great charm is represented in "La Belle Américaine" (the only picture that in subject matter bears any relation to America). The grey tight-fitting gown and the black boa around the neck in conjunction with the assertive and yet so nonchalant pose have a singular charm. As soon as the outlines of a figure are too much oblit- 
erated the charm of colour seems to vanish. Colour alone cannot hold it. It demands form to balance it. Whistler said that painting was every bit as much a science as mathematics. I fear at times he considered it too much a science, at least as far as his colour was concerned. He painted figures, indoors, so low in tone that he could have added a streak of real sunshine at its proper value to the picture. If his darkest canvases grow darker still with age, they will be almost indistinguishable. But his scientific attitude rarely played him false in composition.

Having painted only single figures, it has been doubted whether he had any extensive knowledge of figure composition. This seems to be a futile question. It is my contention that he limited himself to one figure representation, because he knew all about "Old Master" composition.

He wanted one big total effect and did not see how it could have been reached, or had been ever reached by anybody except by one single figure. He had nothing in common with the representation of history, legend or myth and much less of genre, realism of the gutter, or descriptive painting. He wanted to represent modern men and women in the costume of to-day. So he chose the single standing or 
seated figure. Why did he never paint a group! Perhaps he had found it impossible to obtain in a more elaborate composition the result that he cherished most. A painter must paint from the model, to approach any degree of verity. A Monticelli may "fake" or paint from imagination, but his colour masses are a different proposition than life-size figures. The fact must be before one's eyes to render them accurately. One figure in modern costume offers such facts in a natural manner. An elaborate group can be secured only with difficulty, and will never look quite natural. Whistler knew his strength, and did not waste superior energy for a less satisfactory result. This was scientific restraint.

And how he controlled the various forms of representation. He invariably chose the most favourable position. A standing figure offers the widest scope of characterization when shown in a full front view. Nearly all his men, Sarasate, Duret, and Irving are drawn in that position. But a seated figure is shown to the best advantage in a clear profile, every student of composition must arrive at the conclusion, and there was nothing else to do but to paint his "Mother" and "Carlyle" in that attitude. Women on the other hand are more picturesque in outline, also look well, stand- 


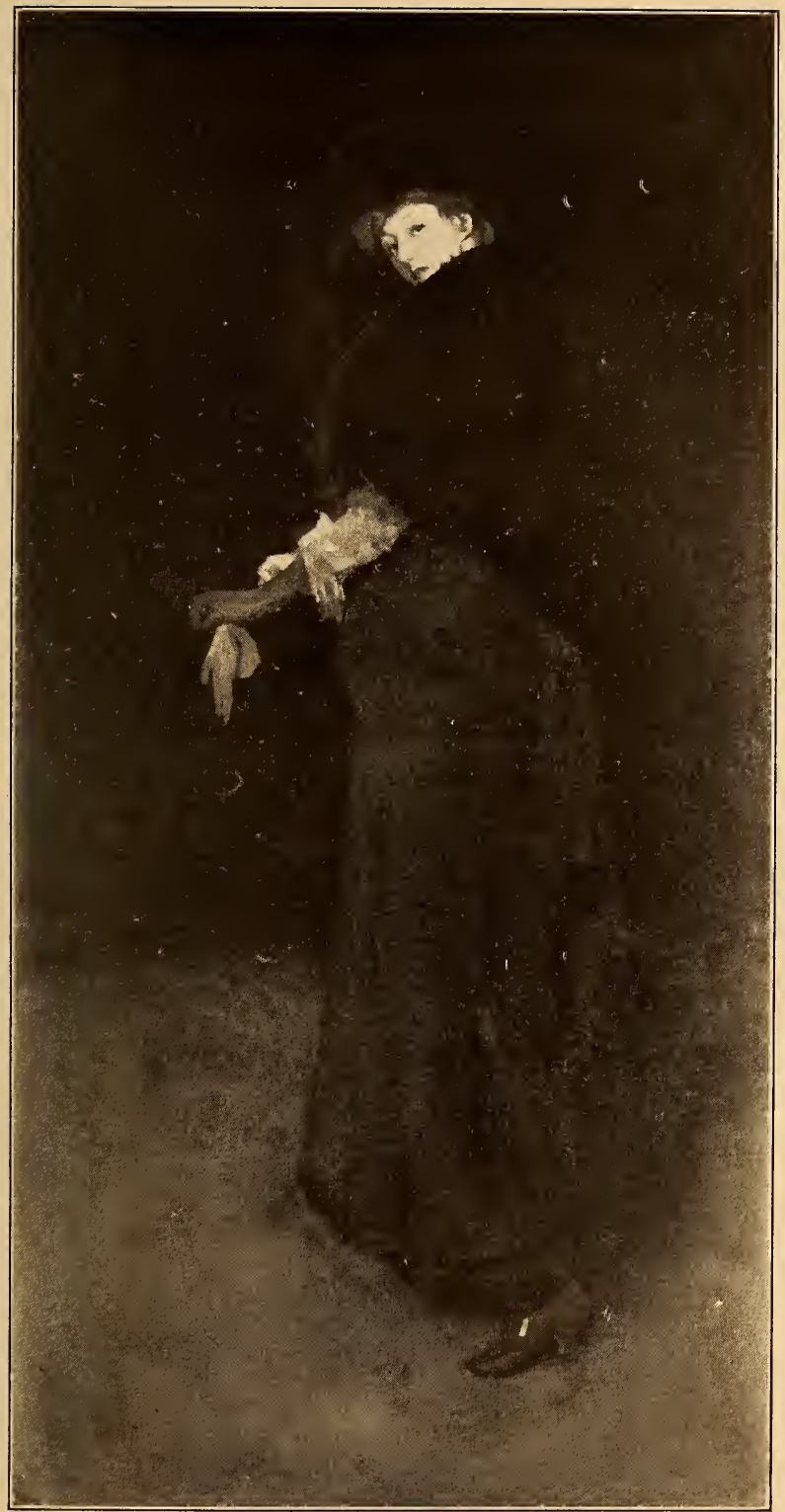

Wilstach Gallery, Philadelphia

ARRANGEMENT IN BLACK: LADY ARCHIBALD CAMPBELL (THE YELLOW BUSKIN). 

ing, in profile with slightly turned face, viz., "Rose Corder," "Miss Alexander," "The Yellow Buskin," "The Fur Jacket," "Mrs. Huth," "Lady Meux No. 2." Also in the delineation of the human face he preferred the simple full-face view, with just a slight shift to the right or left to show the line of the nose. The three-quarter view is undoubtedly more picturesque, and when he painted small heads, among them his own, he frequently used it. In the larger portraits he wanted dignity, breadth, and simplicity and he sacrificed everything to that effect.

The portraits of Miss Cecily Henrietta Alexander (painted in 1872), and Mr. Theodore Duret (painted in 1883), show perhaps in the clearest way that he always worked on the same problem. They are, one may say, the uniting link between the Japanese period and the "Carlyle" and "The Artist's Mother," his most finished and perfect work. They have more colour and grace than most of his pictures, and show the figures with some accessories. Both linger in one's mind as a vision of select refinement.

Little Miss Alexander, with her plumed hat in her hand and her white dress relieved by grey and black accents against a general background, depicts a "pose" such as the painter 
seldom indulged in. There is a flavour of aristocratic coquetry, a flavour of Gainsborough and Boldini in this attitude, an attribute that in this instance is as important to the picture as the unusual colour scale. It took him years to finish this picture, and nobody can appreciate how many weary hours of anguish it cost the little model. More than once it reduced her to tears. One day as she was entering the studio she met Carlyle, who was sitting also for his portrait. "Puir lassie! Puir lassie!" he said. But Whistler had no pity. He had but little consideration for his sitters or models; he forgot their presence as soon as he became entangled in the intricacies of his technique.

The Duret on the other hand shows superior characterization. It may be because the figure is more clearly silhouetted, the outlines of the gaunt figure are as plain as they can be. The painter tried to brighten up the black suit problem with a light background and pink domino. The strange combination of an awkward shape, with almost a touch of brutality in its make-up, and the gay insignia of an opera ball, the domino and red fan, arouse a feeling of grotesque drollery, and yet it is all so forbiddingly proud that one is strongly fascinated by the canvas. 
One of the most important portraits that compete with the Leyland, Duret and Miss Alexander is the "Arrangement in Black:Portrait of the Senor Pablo de Sarasate," painted about 1884 .

Here we have the true Whistler atmosphere, the blurred contour of the violinist's figure, which melts into the background without losing the form, the elimination of all unnecessary details and accessories, and the concentration of light on the face, shirt-front, hands and cuffs. It is astonishing how few bright planes there are in most of Whistler's portraits. In the "Sarasate" the lighted planes scarcely occupy one-thirtieth part of the picture. The rest is all darkness, except the vague shimmer on the floor, suggesting the footlight on the platform of a concert hall. The light floor is one of the leading characteristics of his single standing figures. It helps to suggest space. There is depth in the background; it is not opaque like most backgrounds but vibrant with subtle differentiations of values. The figure is standing in space. One might think at first that this is brought about by the smallness of the figure.

Joseph Pennell says that "what Whistler was trying to do was to paint the man on a shadowy concert platform as the audience saw 
him." Sarasate is intended to look small, less than life-size, as he would appear upon the concert stage. I do not agree with this. I have heard Sarasate play in Europe and America but never saw him on a shadowy platform. To me the conception is a much bigger one. This is not the Sarasate of ardinary life, nor is it the one we know from the concert hall. The artist has attempted to suggest the whole atmosphere that surrounds the life of musical genius. And he accomplished it by introducing a male figure in an ordinary dress-suit with a shimmering shirt front, the outlines of which are lost in vibrant emptiness. Only the violin and bow occupy a certain prominence. "All is balanced by the bow," as Whistler remarked to Sidney Starr.

The figure always seemed to me a trifle small. I personally prefer the Leyland size, as it is more dignified. It does not seem logical to sacrifice beauty and breadth to a mere illusion.

The whole tonal school and pictorial photography in particular have been influenced by the "Pablo Sarasate," now at the Carnegie Art Institute, Pittsburg, Pennsylvania. It gives unparalleled joy to the followers of dark tonalities. As usual the imi- 
tators - painters as well as photographers have exaggerated the extreme rather than normal aspect of the painter's art.

For what is most to be admired technically in Whistler is the frugality, the thinness of his brushwork, that, despite the low pitch and flatness of its colour tints, reveals an astounding variety, subtlety and virility, a vibrancy that seems to radiate from the canvas. For unobtrusiveness of paint Whistler has few rivals. In comparison with him Monet seems a plebeian and Sargent a sleight of hand performer. He combines the fanaticism of a perfect technique with the search for truth and a desire to create new sensations, and expresses our breathless modern life, with all its intricate moods. His art revels in the realms of imagination unknown to Manet's realism, and Zorn's and Sargent's pyrotechnical displays of technique look barbarous in comparison to Whistler's smooth, fluid, unerring brushwork, which masters all the optical illusions of this world with wizard-like dexterity.

He created a style for himself, and his space and colour arrangements have exerted a deep and lasting influence on modern painting. Whether he is as great a painter as some critics make him - whether he is as "big" as Franz Hals, for instance, is still a matter of 
discussion. He will always live in the history of art as being the first man who combined the beauties of Eastern design with the principles of Western art. The mysterious atmosphere of some of his canvases (from which solid forms emerge or recede into), is a poetic translation of Japanese suggestiveness - which does not care to create an illusion, but rather suggests it. Whistler in his portraits was not an initiator of a new art like Monet in his landscapes. He was the last and most perfect of an old school. He merely pushed to their extreme consequence the principles which all great painters since Velasquez have championed. He followed more closely what one might call the thematic development of tone, and discerned more plainly the significance and mystery that lie hidden in blurred objects.

The portrait of the æsthete, Count Robert de Montesquiou de Fezensac, who honoured this shore with a visit (painted in 1890-91), was one of the last pictures of this series. Whistler undertook several portraits of this peculiar, high-strung personality but finished only one. He explained "that it was impossible to produce the same masterpiece twice over - as difficult as for a hen to lay the same egg over twice." The pose is one of hauteur as be- 


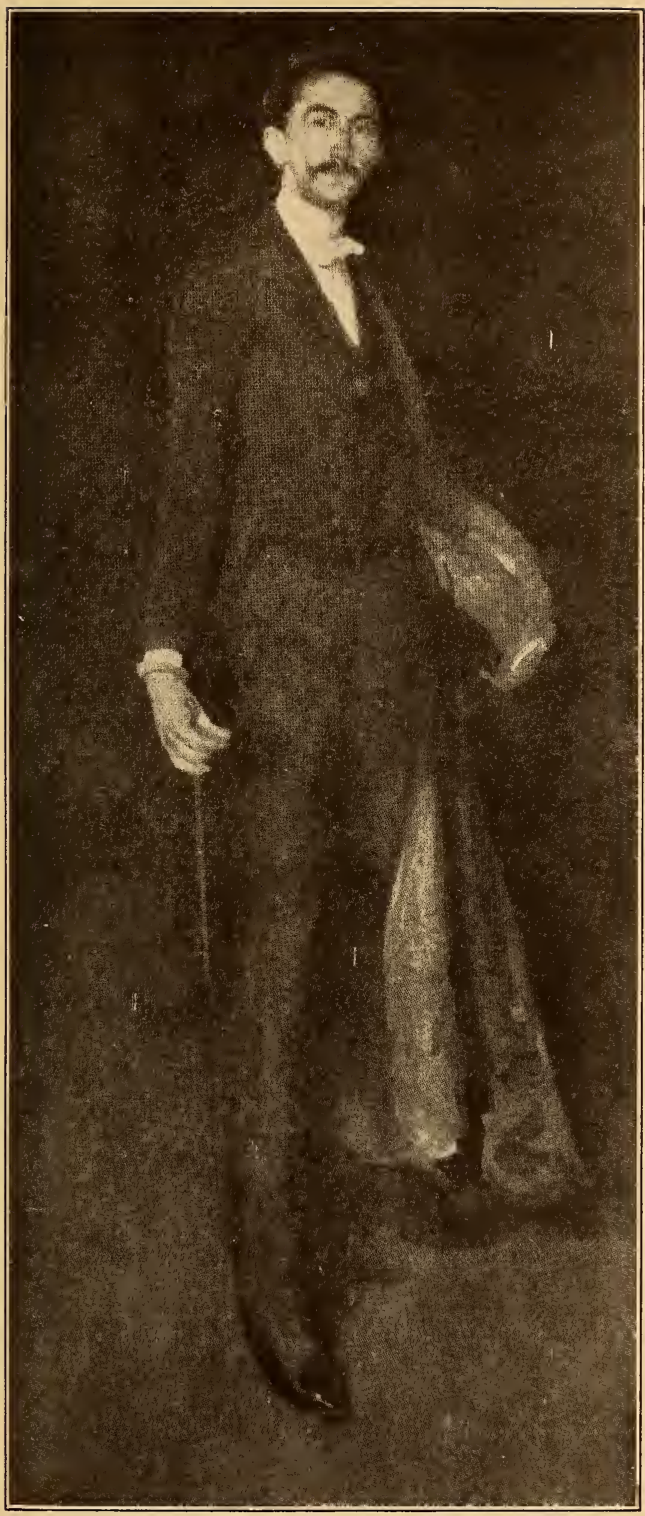

Owned by Richard A. Canfield

ARRANGEMENT IN BLACK AND GOLD: COMTE DE MONTESQUIOU. 

comes the author of "Les Hortenses Bleus." $\mathrm{He}$ wears a dress-suit, and a dark overcoat with a grey lining is thrown over his arm while the other arm thrusts forth a slender cane-like sword. As it is so frequently the case with Whistler's arrangement, it is more a play with colour than a character delineation. A character delineation plus tone is surely more admirable than mere tonality or mere character delineation. In his "Leyland," "Mother," "Duret," and "Carlyle" he accomplished both. In this one he only excelled in one. I also fail to see why he called it "Black and Gold," as I cannot discover the slightest suggestion of gold. It is brown and black. There is little use in reviewing each of his arrangements separately as they all carry out the same principle.

In his two, perhaps, most important pictures, which are generally conceded to be his masterpieces, his "Carlyle" and "The Artist's Mother," both arrangements in black and grey, the painter is a trifle more precise in line. He depicted, as background, actual walls of a room and made an unusual excursion to the domain of space arrangement. Had he at the time arrived at the conclusion that a deep sentiment, no matter how vague, as that of a great philosopher and an adorable woman, can 
be rendered successfully by illusion rather than suggestion!

The "Carlyle" was exhibited as early as 187\%, and purchased after many weary negotiations by the Glasgow City Gallery in 1891. It is a masterpiece of characterization, of tone and space composition. It is a most formidable object lesson to any portraitist. Notice how purely simple and well balanced the composition of "Carlyle" is, how all the details of dress have been eliminated, how the outline has been accentuated against the background, how naturally the figure is seated, and how well it has been placed in space. There is an atmosphere around the figure. One feels that the person is seated in a room.

The same can be said of the composition in the portrait of "The Artist's Mother," at the Luxembourg Gallery, Paris. It was first exhibited at the Royal Academy in London. In the season of 1882 it appeared in America, and then was shown at the Paris Salon in 1888. It was also seen in Munich, and was finally purchased by the French Government in $\mathbf{1 8 9 1 .}$ The simple pose, the delicate way of handling detail in the lace cap and the hands, the masterly space arrangement, produced largely by the rectangular curtain and the silhouette of the figure, the fine sense of values, and the 


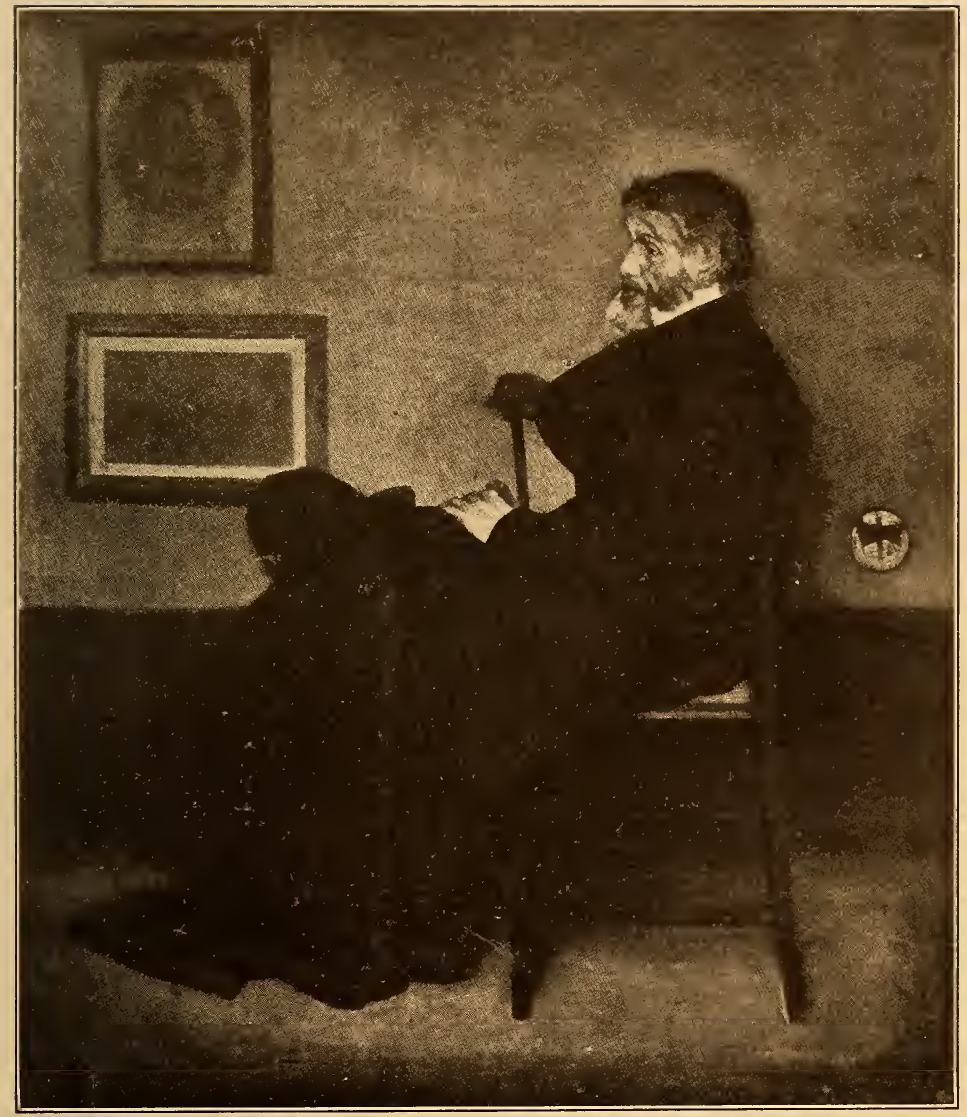

City Art Gallery, Glasgow

ARRANGEMENT IN BLACK AND GRAY. THOMAS CARLYLE. 

clever way in which he utilizes a few frames to break the monotony of the background all have been commented upon a hundred times. No modern painting has been more talked about and more frequently imitated than this one, but none of the adaptations has reached or surpassed its " pathos and tender depth of expression." Technically it is perfect.

It is not the technique, however, which principally interests us in the picture. Just as in his "Sarasate," Whistler attempted in his "Mother" to give us the whole atmosphere that surrounds a personality. Old Mrs. Whistler was a stern Presbyterian and her religious views must have been trying to her son. Yet "Jimmy," though he used to give a queer smile when he mentioned them, never in any way complained of the old lady's strict Sabbatarian notions, to which he bowed without remonstrance. This differentiation of character between mother and son explains much of the rigid Quaker-like and yet so sympathetic pose of the picture.

The artist does not merely represent his old mother. He endowed the old woman, sitting pensively in a grey interior, with one of the noblest and mightiest emotions the human soul is capable of - the reverence and calm we feel in the presence of our own aging mother. And 
with this large and mighty feeling, in which all discords of mannerisms are dissolved, and, by the tonic values of two ordinary dull colours, he succeeded in writing an epic, a symphony domestica, of superb breadth and beauty a symbol of the mother of all ages and all lands, slowly aging as she sits pensively amidst the monotonous colours of modern life. Nothing simpler and more dignified has been created in modern art. 


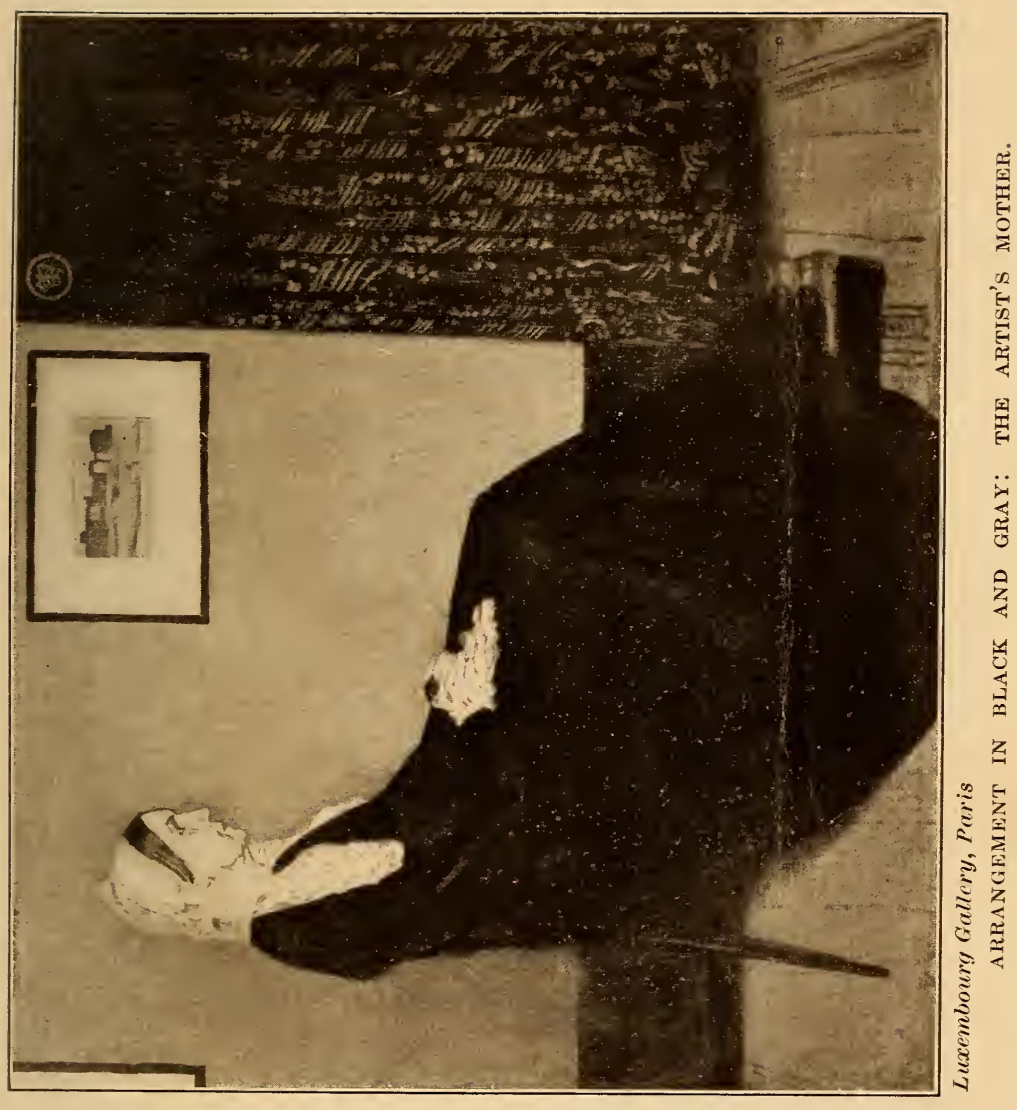





\section{CHAPTER VIII}

\section{IN QUEST OF LINE EXPRESSION}

"Artist, thou art king! Art is the true empire! When thy hand has drawn a perfect line, the cherubims themselves descend to delight themselves in it as in a mirror," wrote Mérodack Peladan, in his preface to the Catalogue of the Salon de la Rose-Croix (1892). He expressed a great truth, that macabre and cabalistic poet-artist.

There is nothing more exquisite, more enjoyable, perhaps, to the art lovers than a perfect line. Pure line expression, as it is found in Dürer, Harunobu, Raphael, and Ingres, is a pleasure apart from all other pictorial representations. It is more intellectual and more remote from all sensuous pleasure than colour, tone, light or shade. It is a language of itself which enables the artist to convey an abstract impression of his individuality.

And no medium expresses line in as pure and unadulterated a fashion as etching. It makes the most of it. Etching is the true wor- 
ship of linear expression. In all other mediums there is a slight desire to hide line, it merely serves as an accessory. In etching it reigns supreme. There are no obstacles to the etching needle except incompetence. It translates every wish of the artist, the slightest accent or deviation with unerring precision and vitality. The Japanese, no doubt, achieved the greatest mastery of the drawn line that has ever been known to history. Only the line form of the Greek competes with it. The Japanese artists revelled in line expression, and it passed through all possible variations, from the sweep of Tanyu's brush and the classic curve of Harunobu to the angular Dürer-like twist of Hokusai. But even their line, unless made by the brush, cannot rival in virility, delicacy and precision the line of a master etcher.

In his paintings Whistler sacrificed line too much. He felt that he had to find a medium in which he had absolute freedom to satisfy his desire and so he alighted upon etching. A draughtsman so sure of himself, so adroit at realizing by simple contrasts of black and white all the effects of which that austere, monochromatic medium is capable of, did not, one supposes, find himself unprepared to use the needle, and, indeed, at the first attempt, 


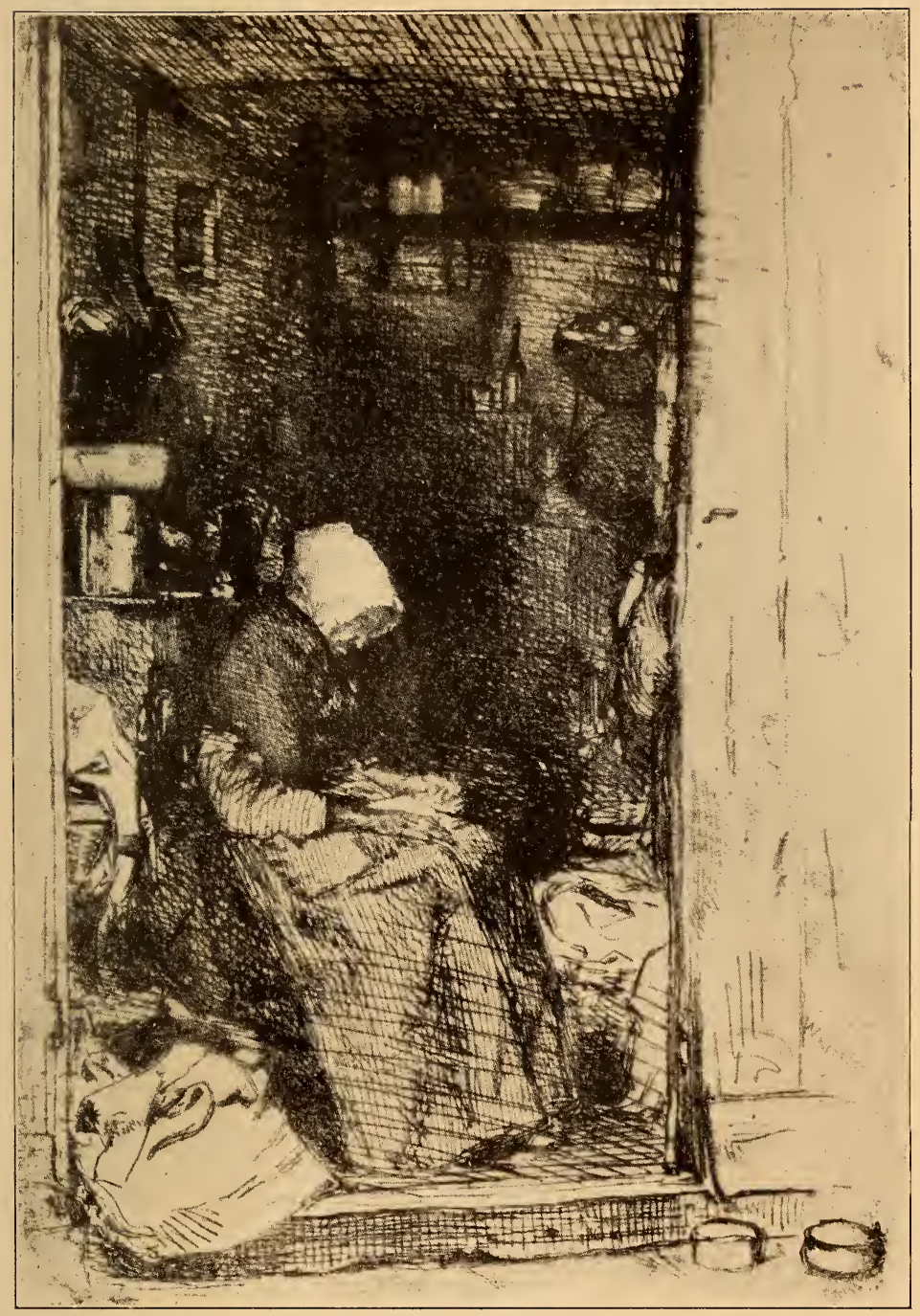

" la vieille Aux loques" (etching). 

Whistler proved himself a successful etcher. True enough, his earliest work, like " $\mathrm{La} \mathrm{Vi-}$ eille aux Loques," "La Marchande de Moutarde," "La Cuisine," and " La Mère Gérard," betrays a keen sense of the beauty of material; but they are, after all, conventional productions and show a slight influence of Rembrandt's etchings and the Little Dutch Masters. They are attempts at realistic picturemaking, and, no matter how broadly the objects are conceived and carried out, look spotty. The light and shade division could be more scientific, and the tonality consequently a finer one. Too many little things fill out the pictorial scheme. He still worked for the effect of dignified completeness and had not yet learned to apply his later sense of elimination. The certainty and freedom of his draughtsmanship is always admirable. There is no academic pedantry in his drawing and no laborious effort. The beholder is charmed by its fascinating expressiveness and delightful flexibility. His perspective views and figure subjects convey an impression of unhesitating knowledge of form and contour and of an exact understanding of subtleties of modelling. They show no struggle with difficulties of statement; everything seems to come right, as a matter of course, and to fit together natu- 
rally without any deliberate intention on his part.

It was in 1855-58, during a trip to Alsace Lorraine with Delonney, an artist friend, when he made his first attempts at etching. A few dated prints like the "Scene in Alsatian Village" and "Street at Saverne" of this period are highly treasured by collectors, and pronounced as good as any that came after. A few years later, in the sixties, he took up the process more seriously and remained its ardent disciple ever afterwards. In the eighties he devoted more time to his etchings, pastels and water colours than to larger paintings. His fastidious love for rare and picturesque subjects made him select a number of favourite sketching grounds. They were the Thames embankments, of which he never tired, the French towns of Tours, Bourges and Loches, also Venice, and the Netherlands. Of course, like every true artist, he etched everything that appealed to him. There are numerous London and Paris sketches, scenes from Ajaccio and Algiers, and many figure compositions, character studies and portraits. But his French, Thames, Belgium, Holland and two Venice series are probably the most interesting from a collector's point of view, as they combine in a more pronounced manner 


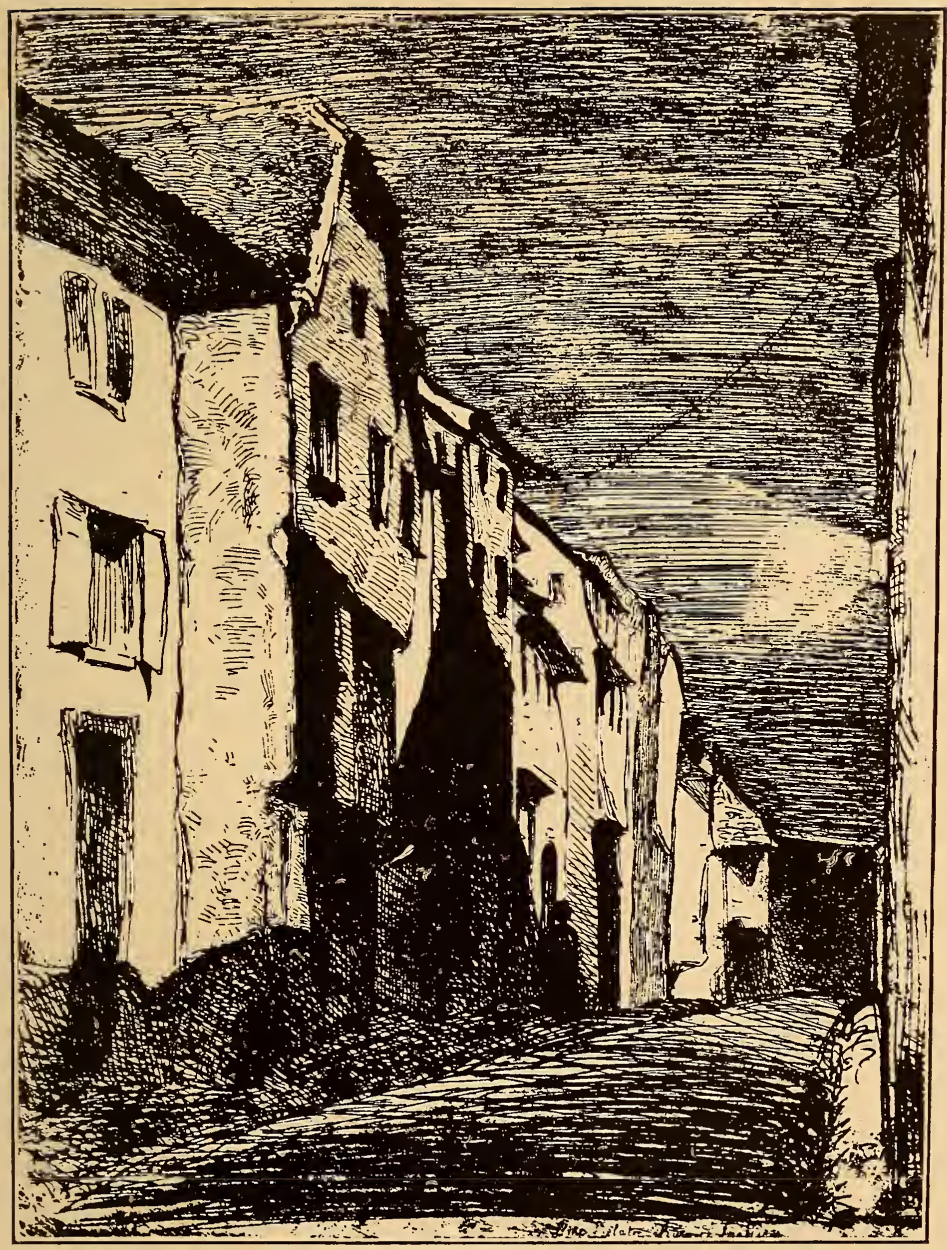

STREET IN SAVERNE (ETCHING). 

direct Whistlerian methods with the quest of line expression.

His first designs of the Thames series were made in 1859. Some few themes recur with many variations, such as the battered shopfronts of Chelsea, "The Pool," the London bridges, the barges on the river, and the wharfs, warehouses and factories, like "Price's Candle Works." A few years later he made a trip through the northern part of France, and one of the finest results was the "learned, spirited" "Hôtel de Ville at Loches."

In 1879 he made his first trip to Venice, stayed fourteen months and made forty-four etchings during the time, including "Little Venice," "San Biagio," and "The Garden." In later years Holland attracted him almost as much as the city of the Adriatic. It is interesting to note his absolute disdain of literary associations. To him Venice was not, as to Heine, the city of Shakespeare. When he crossed the Rialto and Piazzetta he did not hear the voice of Shylock lamenting for his daughter, nor did he conjure up splendid visions of decayed power, as did Ruskin in his "Stones of Venice." The Venice of Claude Lorraine and Turner existed for him as little as the panoramic suavity of a Canaletto. $\mathrm{He}$ was satisfied with sitting at a little trattoria 
near the old Post Office, at Florian's, or in his simple sitting room at San Barnaba, dreaming of some linear expression of an old bridge or archway, of some enchanted fragment of vision, or a peculiar flush of colour over the Grand Canal. To him Venice was a modern city. He only saw what was actually there, and when it fascinated him, he seized his burin or crayon and endeavoured, with frank directness, to record the pictorial event. $\mathrm{He}$ invariably chose subjects that appealed to the experienced collector rather than the general public. He never idealized or conventionalized, nor did he belong to those who only see the ugly side of life, its squalor and unpicturesqueness.

Some of Whistler's admirers have pronounced him not only the greatest etcher of the day, but of all times, and compared him to Rembrandt. This comparison is not without justification, inasmuch as Whistler was not a professional etcher but a great artist who, like Rembrandt, took up the etching point as an instrument for new expression. They both sketched with wonderful freedom. They were no mechanics; under their hands the point lost the engraving look and became wonderfully free. Still, to say that Whistler was the best etcher of the day is rather a sweeping expression. Lalanne, Jacquemart, Appian, 


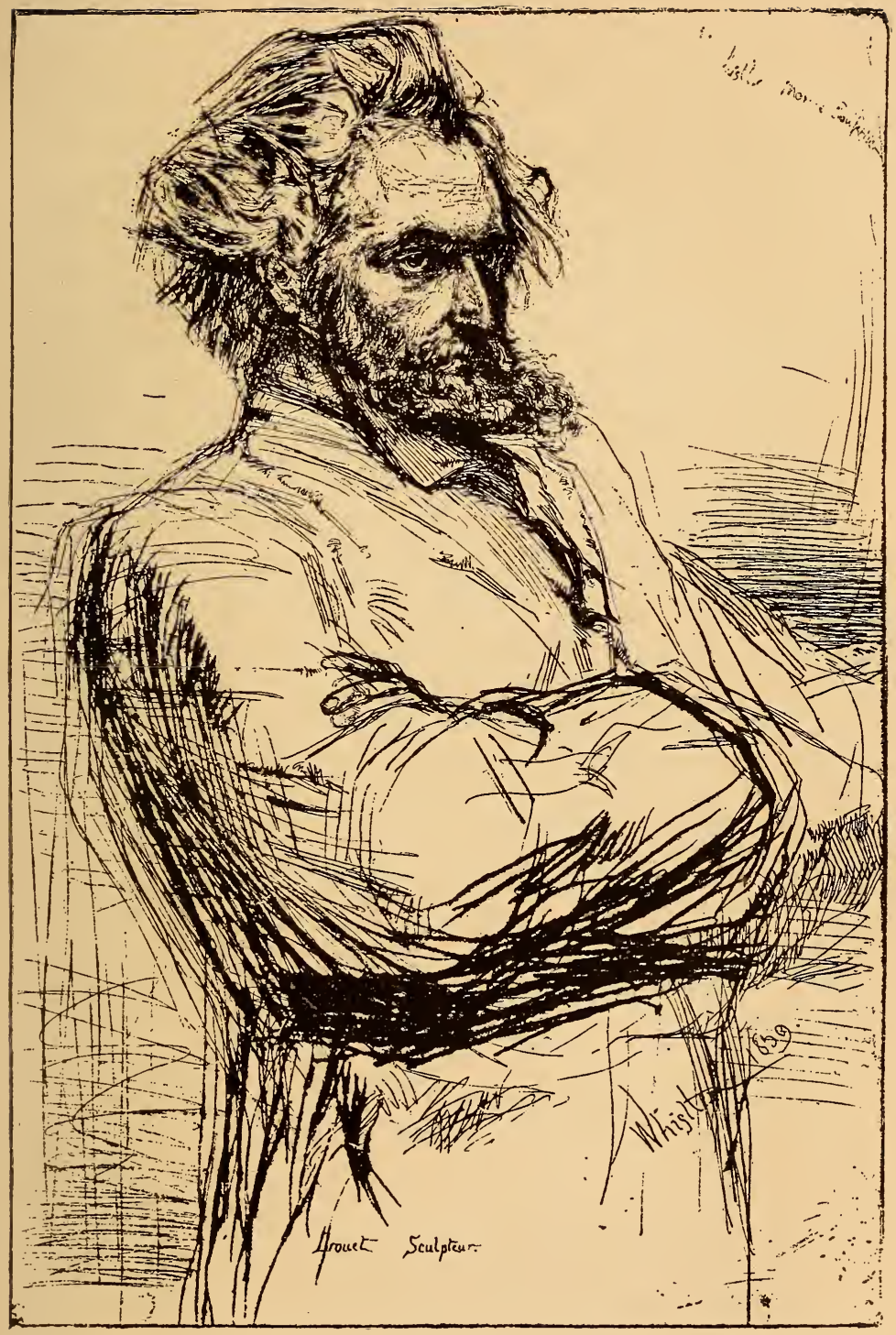

PORTRAIT OF DROUET (ETCHING). 

Veyrasset, Meyrion, Zorn, Pennell, Raffaelli, Rops and Klinger are all wonderful etchers. In painting, his mastership is indisputable. In etching I do not feel it quite as keenly. There is not the slightest doubt that etchings like "Jo," "The Adam and Eve Tavern," "Chelsea," "Soupe à Trois Sous," "The Lion's Wharf," the beautiful little still life "The Wine Glass," the portrait of " Becquet," "Unsafe Tenement," the "Battersea Bridge" of 1879 - " a masterpiece of masterpieces" show uncommon ability, which gives up everything to the right point and never beyond it. One of the most ravishing designs is his "Girl on a Couch." "The Model Resting," quite different in execution, is scarcely less captivating. But much of his work seems to be a little too elaborate, too overcrowded with line work. I do not particularly admire prints like his "Southampton Docks," "Portrait of Drouet" or "The Silent Canal." This is more astonishing when one compares them with the frugal technique of his paintings.

A rather just, though somewhat pedantic, criticism came from the pen of Hamerton in 1881:

"Amongst living men Whistler may be cited as an etcher of rare quality in one important respect, the management of lines, but his 
etchings owe much of strange charm which they possess to Chinese disdain of tonal values, and to wayward caprice, loving it here and scorning it there, which, being strictly personal, can only be of use as an example in one sense, that it shows how valuable in art is genuine personal feeling. Whistler is an admirably delicate draughtsman when he likes; there are passages in his etchings which are as striking in their way as feats of execution, as the most wonderful passages of Meyrion."

There can be little fault found with this statement. I take objection only to the "wayward caprice" and the "Chinese disdain." I think that Whistler learned "loving detail here and scorning it there " only in his later works. It came out strongly in compositions like "The Balcony," "Doorway," and "Palace " and obtained full mastery in his "Dutch" series, above all the fascinating "Amsterdam Canal" piece, when the lines were so vague and subtle that deep biting was impossible and a few impressions would efface the design. As for the Chinese disdain of tonal values, I think it is Whistler's particular merit that he gradually abolished tonality altogether, and, in his later work, rarely resorted to cross-hatching. He laid more stress upon the simplification of line. Etchings can produce tonal sensations, 


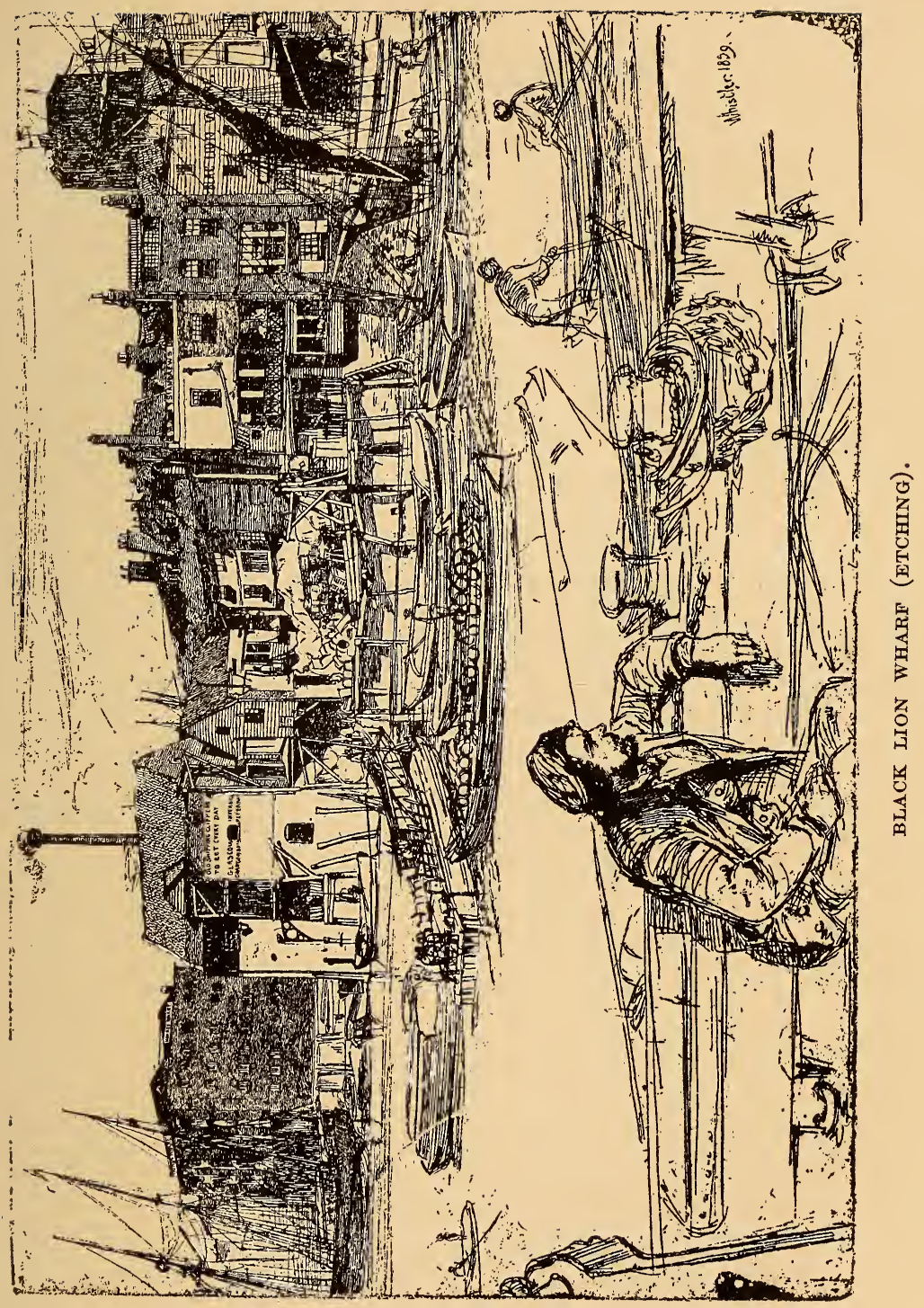



but it is surely not the main object to strive for. Whistler followed Haden's doctrine that the line ought to be preserved as much as possible, and made the most of it. If the linear expression is sacrificed in etching there is no executive expression left; there is no brushwork to take its place; the etcher is working with a point and not with a brush, and there must be primarily point expression, that is line expression, or none.

Otto $\mathrm{H}$. Bacher has written a few analytical notes of Whistler's line work. "Where it required accuracy he was minute. $\mathrm{He}$ used his needle with the ease of a draughtsman with a pen. He grouped his lines in an easy, playful way that was fascinating. They would often group themselves as tones, a difficult thing to get in an etching. He used line and dot in all its phases with certainty. Sometimes the lines formed a dark shadow of a passage through a house, with figures in the darkness so beautifully drawn that they looked far away from the spectator. These shadows which so beautifully defined darkness were made only by many lines carefully welded together and made vague as the shadows became faint in the distance or contrasted with some light object. He made his etched lines feel like air against solids. . . . If he etched a doorway, he played 
with the lines and allowed them to jumble themselves into beautiful forms and contrasts, but was always very careful of the general direction they should run as a whole." Bacher saw a good deal of Whistler in Venice, perhaps more so than any one else, and his observations on Whistler's etching tools, how he ground and bit his plates, are extremely interesting. "In grounding plates Whistler used the old-fashioned ground, composed of white wax, bitumen, pitch and rosin. He heated the plates with an ordinary alcohol flame, holding the plate in a small hand vise. The silk covered dabber that spread the ground over the plate was fascinatingly managed by Whistler. ... When he came to smoking the plate he preferred the old wax taper made for that purpose. He kept his two etching needles, very sharp ordinary dentist tools, in cork, to preserve their fine points. Whistler always had his stopping-out varnish with him in a small bottle, applying it with a brush in a most delicate manner. He did not make use of any mirror but preferred the old negative process. When he bit a plate he put it on the corner of a kitchen table, with his retouching varnish, etching needle, feather and bottle of nitric acid, at hand, ready for instant use. Taking a feather, he would place it at the mouth of the 
bottle of acid, tipping bottle and allowing acid to run down the feather and drip on plate. He moved bottle and feather always in the same position around the edges until plate was covered, - would use feather continually to wash acid backward and forward upon the plate, keeping parts equally covered, and blowing away air bubbles."

Frequently Whistler sketched directly on copper plates. He carried the prepared plates in his pockets or in a book and when he found a motif sketched it in improvisatore fashion. His sketches of the "Annual Review at Spithead," in 1887, show his uncommon facility as a sketch artist. $\mathrm{He}$ was the champion of dry point. Already during the Leyland period he selected dry point as a favourite medium. And in this, to my notion, lies the strength of Whistler as an etcher. "Whistler added," as Joseph Pennell has so beautifully said, "a new scientific method to the art of etching - that of painting on the copper plate with the needle."

As a printer of his own plates he seems to have been quite an expert. $\mathrm{He}$, no doubt, allowed himself great latitude and experimented with each plate, so that few impressions resemble each other. Although he had abolished blacks and dark tonal passages at an early 
date, he frequently painted on the plate with printer's ink, and went through an elaborate process of wiping. Of course this makes the excellence of the impression uneven, but also makes a particularly good one a more valuable possession.

The intention was always the same. From the very start he sought for the same arrangement of lines and spaces, the same effect as in his Venetian plates. He wanted breadth not breadth of line itself, but breadth of expression. After all it was a growth and slow development. He became simpler and simpler, and well nigh reached perfection in his Parisian series of 1892-93, of little shops, boulevard scenes, and public gardens, and in prints like "The Little Mast," "The Riva," "The Barber," and "Zaandam" he acquired his wonderful sense for right workmanship on a small scale. Some of his etchings of fragments of architecture have never been surpassed in sketchy treatment; most noticeable perhaps in the exaggerated simplicity of the "London Bridge" and in the Holland series of the nineties. There we realize that great simplicity of motif is dependent on great simplicity of genius. The effects are so spontaneous and subdued that their value might well escape common observation. The extreme 
sensibility is a matter of both touch and vision. His plates look as if the rapidity of execution had been extraordinary, and yet his line, as delicate at times as in silver point drawings, is not exactly what we could call nervous, but of remarkable freedom and unerring precision. It is piquant and sprightly, subtle and alert.

The lines can almost be counted in some of his later etchings. He had learned the truth of the proverb "Wise economy is everything." It was even more than wise economy. It was the highest expression of artistic wisdom, which had almost disappeared since the surface decorations of Greek vases, in which mood, character and incident were reduced to a few details, strong enough to incite in the imagination of the beholder all that was eliminated.

Every art is at its best when it is most itself. Nobody realized this more than Whistler, who invariably emphasized this. He had an absolutely clear idea of what every medium could do. In his larger paintings it was the exploitation of a few dull colours, of a silhouette in space combined with psychological research; in his nocturnes, a play of slightly differentiated tones; in his water-colours a mere suggestion of reality; and in his pastels a certain joyousness of expression. Pure line, caprice of detail, 
distance and atmosphere, he reserved for his etchings; and a subtle expression of values of "moss-like gradations" for his lithographs. His decision may not always appear right to others, but it was right to him. How carefully he thought out these technical problems is shown in his "Propositions," which he addressed to an American etching club that had invited him to take part in a competition of large plates. He wrote the following series of maxims that should be posted on the wall of every studio:

"That art is criminal to go beyond the means used in its exercise."

"That the space to be covered should always be in proper relation to the means used for covering it."

" That in etching, the means used, or instruments employed, being the finest possible point, the space to be covered should be small in proportion."

"That all attempts to overstep the limits insisted upon such proportions are inartistic thoroughly, and tend to reveal the paucity of the means used, instead of concealing the same, as required by art in its refinement."

"That the huge plate, therefore, is an offence - its undertaking an unbecoming display of determination and ignorance - in ac- 


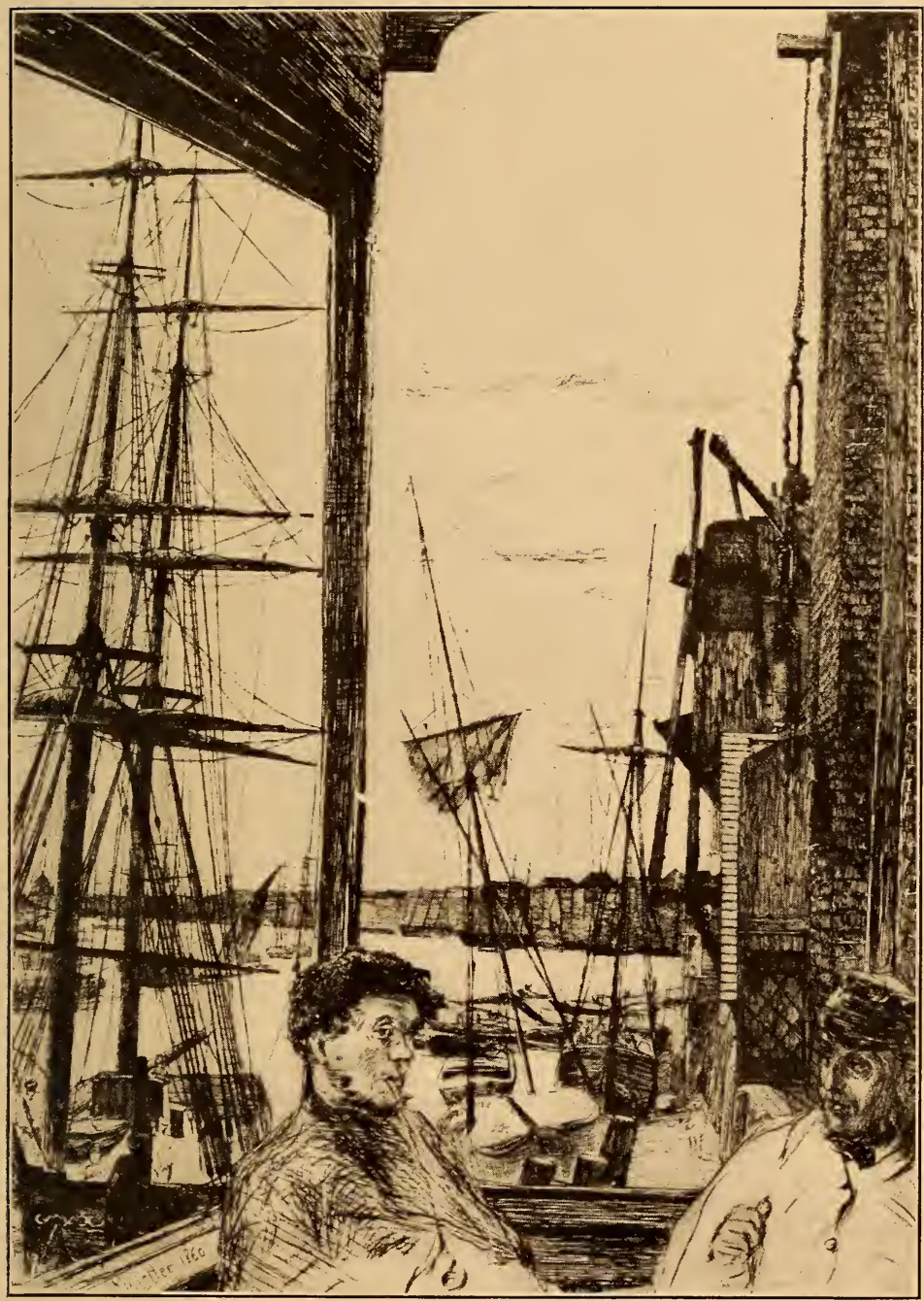

WAPPING, ON THE THAMES (ETChING). 

complishment a triumph of unthinking earnestness and uncontrolled energy - both endowments of the "duffer." "

"That the custom of 'Remarque' emanates from the amateur and reflects his foolish facility beyond the border of his picture, thus testifying to his unscientific sense of its dignity."

"That it is odious."

"That, indeed, there should be no margin on the proof to receive such 'Remarque.'"

"That the habit of the margin, again, dates from the outsider, and continues with the collector in his unreasoning connoisseurship taking curious pleasure in the quantity of the paper."

"That the picture ending where the frame begins, and in the case of etchings, the white mount, being inevitably, because of its colour, the frame, the picture thus extends itself irrelevantly through the margin of the mount."

"That wit of this kind would leave six inches of raw canvas between the painting and its gold frame, to delight the purchaser with the quality of the cloth."

We may not agree with his conclusion on the margin and remarque. The latter, no doubt, was introduced by the artist to please the purchaser. It is therefore, if a fault at all, that of the artist as much as of the collector. 
The question of margin is an individual one. There is little difference between a mat and a margin, and the Japanese print and the framing of black and whites in general have taught us the utility of uneven spacing around the picture. The remainder of the argument is excellent, theoretically as well as æsthetically.

Whistler's composition, excepting the French set, was strictly impressionistic. One merely has to look at the "Cadogan Pier," "The Little Pool," "Old Hungerford Bridge," "Little Wapping," "The Velvet Dress," "The Dam Wood," "The Long Lagoon," etc., to come to this conclusion.

The word impressionism is rather difficult to explain. It is on the tongue of everybody, and yet few mean exactly the same thing when they make use of it. The term applied formerly to every art expression - as every artist endeavoured to render an impression - has been specialized in the latter half of the last century. It has become the nickname of a definite number of painters, who have adopted a new palette (as suggested by scientific researches) and introduced a new method of laying colours on the canvas. In recent years the term has undergone another change - it has become a general claim for individuality of subject and treatment. 


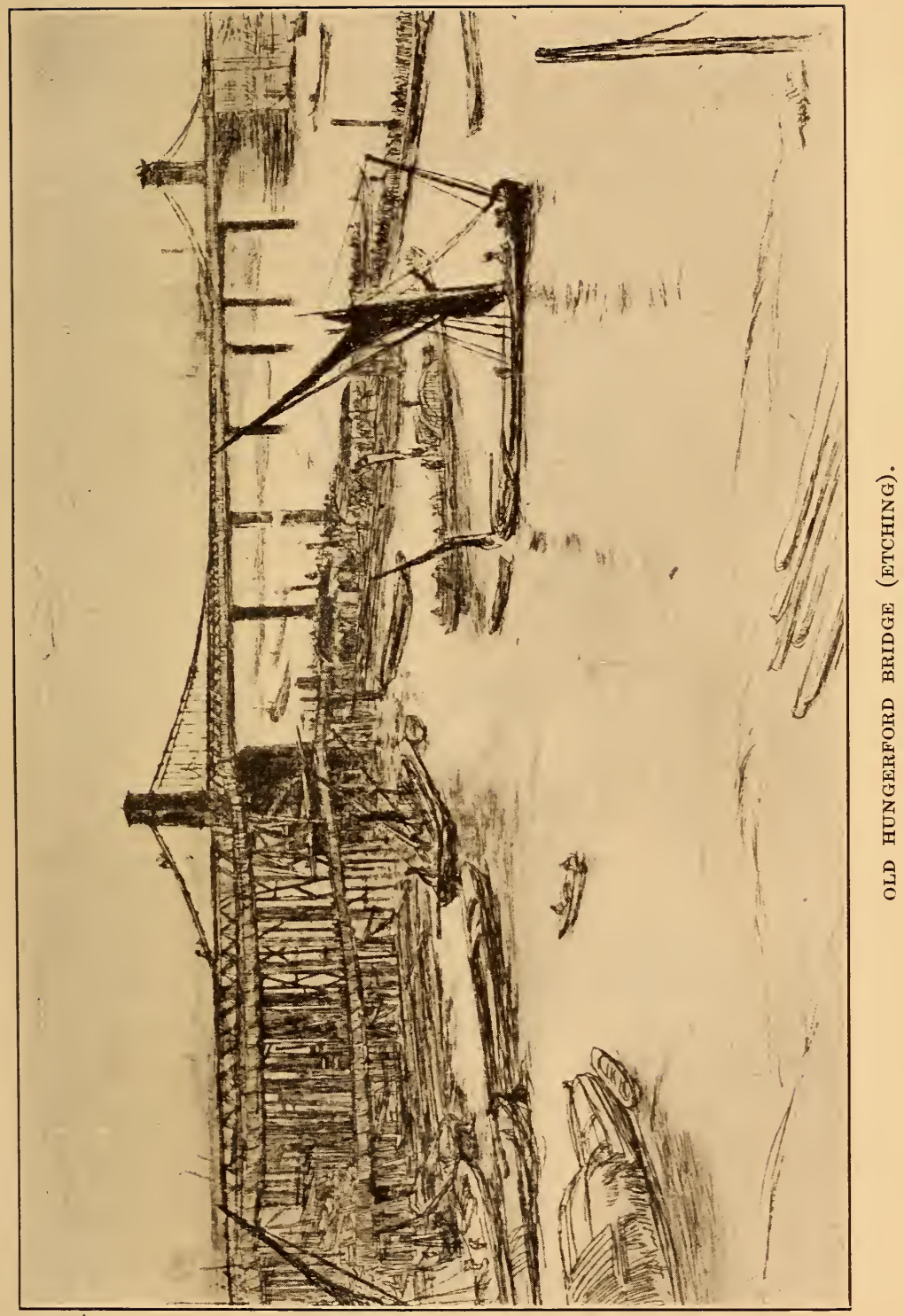



First of all, let us determine what difference there really is between the old and the new style of impressionism. The artist of the old school received an impression and elaborated upon it. He embellished it with all his art was capable of, and the original impression underwent all sorts of changes. It was merely the first inspiration - the foundation stone upon which the whole art structure was erected. The artist of the new school, on the other hand, endeavours to reproduce the impression he has received, unchanged. He wants the impression itself, and wants to see it on his canvas as he has seen and felt it, hoping that his interpretation may call forth similar æsthetic pleasures in others as the original impression did in him. It is a singular coincidence, indeed, that while the men of the lens busy themselves with imitating the art of several centuries ago, those of the brush are seeking but for the accuracy of the camera plus technical individuality.

The impressionist painters adhere to a style of composition that apparently ignores all previous laws. They depict life in scraps and pigments, as it appears haphazard in the finder or on the ground glass of the camera. The mechanism of the camera is essentially the one medium which renders every interpretation impressionistic, and every photographic print, 
whether sharp or blurred, is really an impression.

How did the impressionistic painters arrive at this new style of composition? Permit me two questions. When was impressionism introduced into painting? In the sixties. When did photography come into practice? In the early forties. Do you see what I am driving at? Photography in the sixties was still a comparative novelty, and consequently excited the interest of pictorial reformers more than it does to-day. Its influence must have been very strongly felt, and the more I have thought of the nature of this influence the stronger has become the conviction in me that the impressionistic style of composition is largely of photographic origin.

Impressionistic composition is unthinkable without the application of focus. The lens of the camera taught the painter the importance of a single object in space to realize that all subjects cannot be seen with equal clearness, and that it is necessary to concentrate the point of interest according to the visual abilities of the eye. There is no lens, as everybody knows, which renders foreground and middle distance equally well. If three objects, for instance, a house, a tree and a pool of water, stand at different depths before the camera, the photog- 


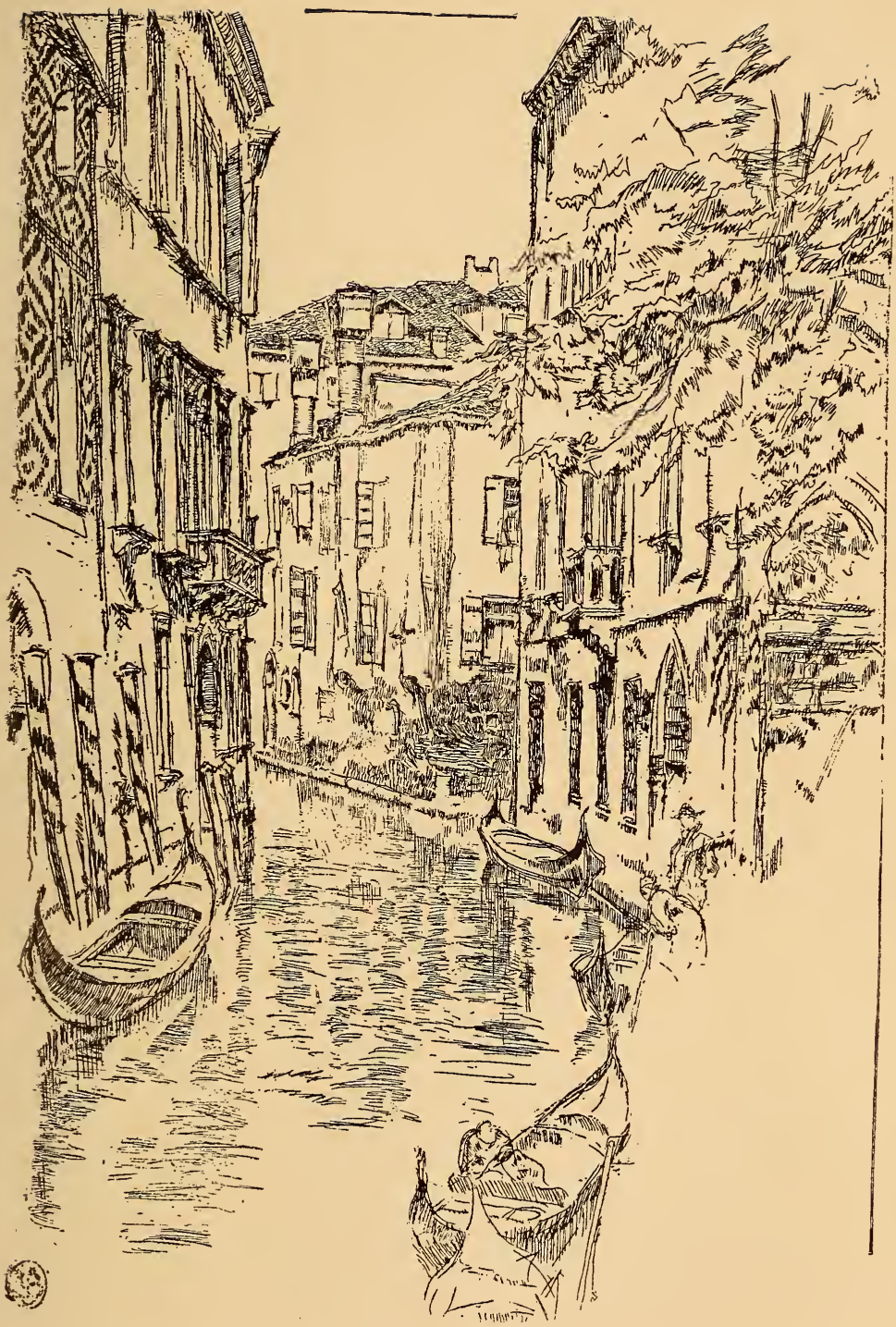

THE SILENT CANAL (ETChING). 

rapher can, at will, fix either the house, the tree or the pool of water, but whatever one of these three objects it will be, the other two objects will appear less distinct.

The human eye could have told the painter the same story, as the eye naturally and instinctively rests on the most pleasing part of the scene, and in so doing, puts out of focus more or less all the other parts. It is a curious fact that all the compositions of the Old Masters were out of focus. True enough ther swept minor light and colour notations into larger ones, but there seldom was any definite indication in their work whether an object was in the foreground or middle distance. This way of seeing things was, no doubt, a voluntary one - they had a different idea of pictorial interpretation. In their pictures, as in nature, we continually allow our attention to flit from one point to the other in the endeavour to grasp the whole, and the result is a series of minor impressions, which consciously influence the final and total impression we receive from a picture. The impressionist is satisfied with giving one full impression that stands by itself, and it was the broadcast appearance of the photographic images in the sixties that taught him to see and represent life in focal planes and divisions. 
In the catalogue of Whistler's etchings, arranged by Frederick Wedmore in 1886, we find 214 prints enumerated and commented upon. In a later edition the number had increased to 268. In the Catalogue of etchings of James McNeill Whistler, compiled by an amateur and published by Wunderlich in New York, 1902, and which claims to contain all known etchings by the artist, the number is 372.

But as Whistler was working on copper all his life, it is difficult to state how many etchings he really made. Joseph Pennell, who probably knows more about this phase of art than any living man, makes a statement as follows:

"I know little, and can say less, of the state of his plates, - and I believe himself knew little more about them, - how many were printed, whether they exist or not, or what has become of the coppers. All I do know is that in the case of the Thames set, long after Whistler or Delâtre - I am not sure which - had pulled a certain number of proofs, long after the plates had been steeled and regularly published, about 1871, and later still, after a Bond Street dealer had been selling them in endless numbers to artists for a few shillings each, the idea was suggested to another dealer that he 


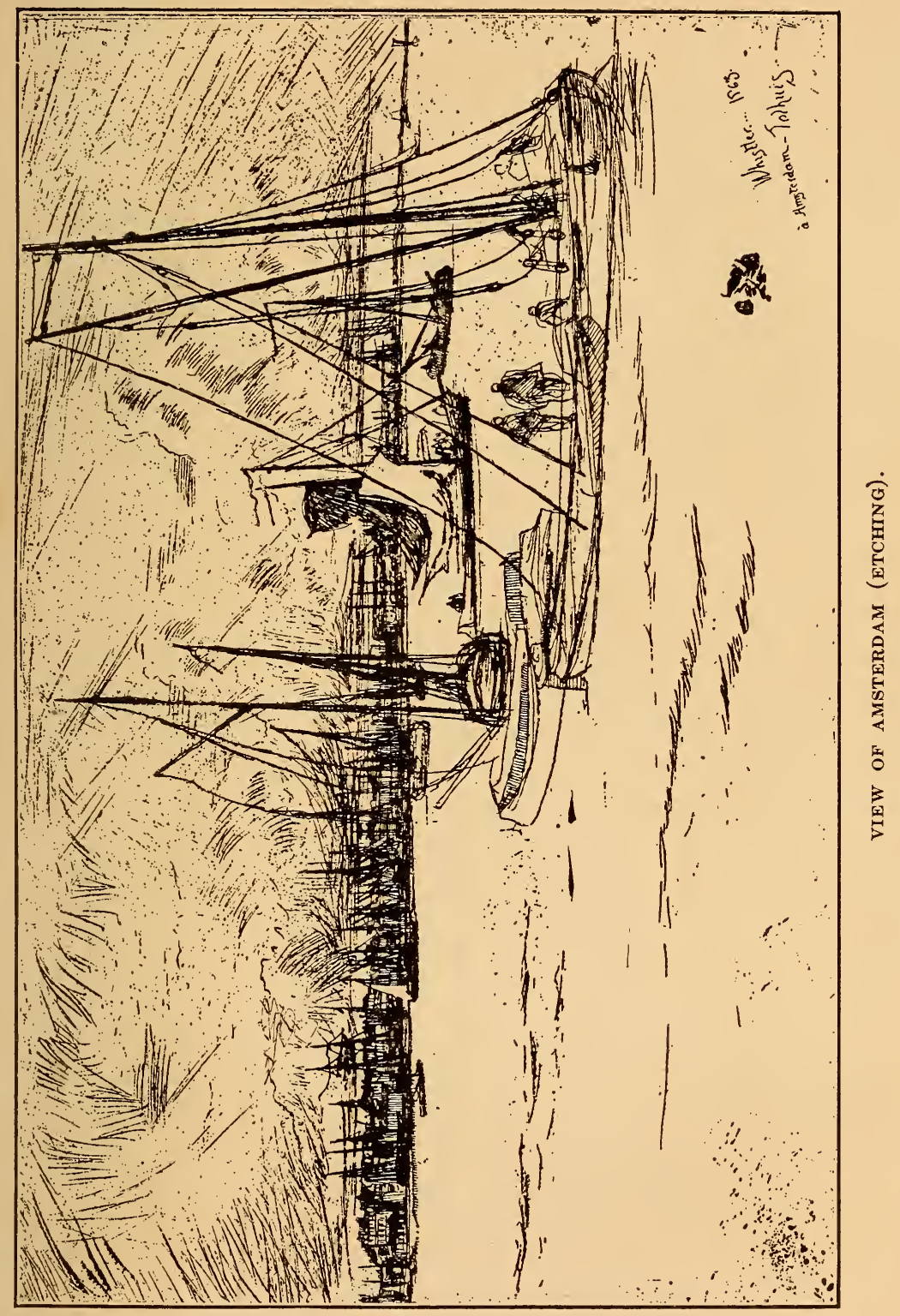



should purchase the copper plates, remove the lead facings and, if they were in condition, print as many as the plates would stand, or, if they were not, destroy the plates and sell them; for even Whistler's destroyed copper plates have a value. The experiment was tried, and extraordinarily fine proofs were obtained. I believe collectors resented this very much, but artists rejoiced, and the world is richer by a number of splendid examples of the master."

Whistler gave etching a new impetus, and a new significance in the use of line; even as Mrs. Schuyler Van Rensselaer has so well expressed it: "in telling use of a line he has no superior among the modern and few equals in any age."

His work is never dull, nor cold, nor commonplace. It is always fascinating and capable of provoking æsthetic sentiments. At times it is of "slight constitution," a mere passing fancy, leaving many objects in the stage of mere suggestion, but it always has a finished look. And finish, as he understood it, meant the carrying on of a technical process until it had fulfilled to the utmost its mission and explanation, until not a touch more was needed to make clear the intention which the picture embodied. 


\section{CHAPTER IX}

\section{MOSS-LIKE GRADATIONS}

Grey is the colour of modern life. There is some truth in the statement. Modern civilization shuns the slashed doublet and purple cloak. Beauty of colour, as a Titian and Veronese understood it, belongs to the past. The brilliancy and splendour has faded out of it. The modern painter uses a more limited scale of colour, and the tendency is toward grey.

Man's garb is monotone, and the life in large cities devoid of the rich colour-bursts of mediæval life. The contrasts are all in lower, paler and murkier tones, and grey, in most instances, furnishes the keynote and general harmonizer. All the artists who have a fine feeling for the arrangement of colours have realized that harmonies of red, green and violet, which shone so resplendently from the warm brown tones of the Old Masters, are the dreams of another age. Even the impressionists, by the very character of their technical innovations, notably the abolition of browns, 
the struggle for a higher pitch of light by the interaction of purely applied colours and the exaggeration of the transparency of shadows, are pursuing the grey phantom of modern art. Their ambition is no longer a combination of bright colours, as in Veronese's " Marriage of Cana," but a tonality of dull yellow or green, which pervades the whole surface of the pictures. The flowing robes, flowers and gold ornaments, once so radiant on the canvases of the Renaissance, have turned as pale as ashes.

We take delight to-day in subtler gradations, in semi and quarter tones, the losing of forms in mystic shadows, a restless, suggestive technique of mobile touches, nervous sparkles, of delicate broken tints that show a hundred differentiations. And this over-sensitiveness and fastidious objection to strong contrast, this love for the externals of technique, raising brushwork to a higher pedestal than the idea, has much to do with the exclusiveness of modern painting and the keener appreciation for monochrome.

In monochrome representation the eye has to deal only with one mode of perception that of form. The perception of colour depends upon the differentiation of the effect upon the optical nerve fibres, that of form on the numbers and relative position of the latter. 
The latter mode of æsthetic perception is, in our times, more trained and developed, as it is in constant usage. Reproductive processes, the halftone and photography, have made monochrome a vehicle of expression almost as popular as the spoken word.

To former ages only the various processes of engraving were known. With the exception of etching and wood engraving, they were applied largely to popularize the products of painters, and the independent etchers and block-cutters generally adhered to a severe and classical style of art. It was the nineteenth century with its principle of universal education, newspapers, books and manifold publications, that brought about the great change.

Texture constitutes to most collectors the principal charm of the graphic arts. It is a rare and fantastic valuation, an appreciation of preciosity, this occupying oneself with the fascination of the minor arts. Art would be too austere if it were not for the makers of etchings and lithographs, of pastels and watercolours.

Photography, the latest arrival in the ranks of the graphic arts, has the widest range of expression, and its technique is interesting as far as it can express mechanically and with 


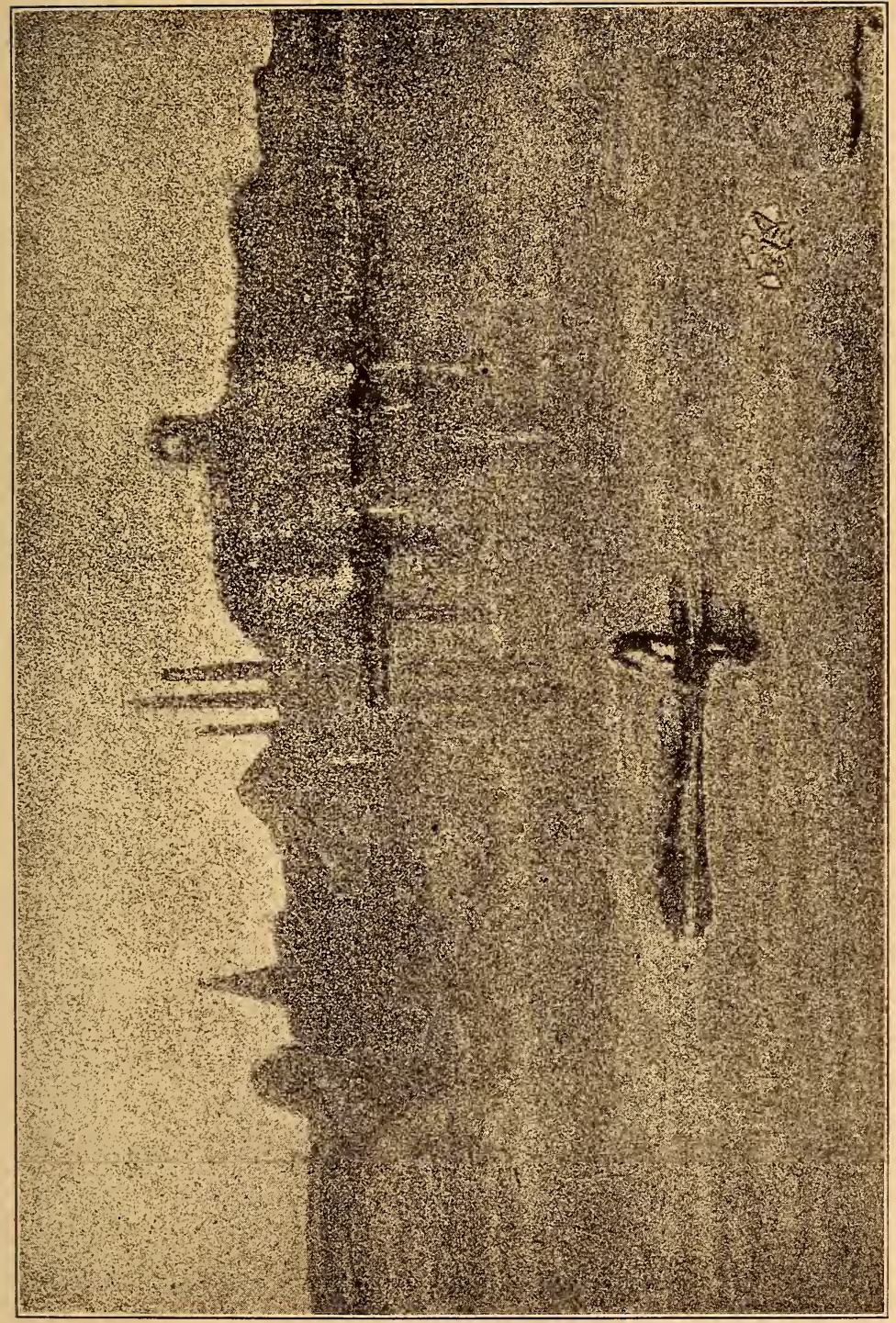

II 

comparative ease gradations of tone that without visible touches, marks, strokes or lines melt imperceptibly into each other. But this smoothness of texture will also be its most formidable drawback. There is no chance for manual expression without destroying the charm of photographic texture. Chemistry is the only legitimate means to accomplish it.

Copper and steel engravings lack that freedom of expression, and are restricted largely to reproductive purposes. Carried out by cross-hatching, they are limited by the black of the ink and the white of the paper, and the precise character of the line work. Modern reproductive wood engraving, notably of the American school, is the only medium which has conquered the subtleties of tone.

The scale in monochrome painting in colour is so limited that few artists apply it. India ink and sepia, however, are much in favour, and if handled by an artist, fulfil the requirements of painting. The only short-comings are a certain transparency in the middle tints and an artificial look in the texture.

Charcoal and chalk have a great similarity, and also lend themselves to elaborate composition, although the more delicate and lighter greys are frequently muddy. Pen and ink can merely give an impression of line, and 
next to etching it is the best medium for sketching, only a less pliable one, which is largely due to the unelasticity of the steel pen; all subtler gradations are left out, as the brightest tints are lost in the white and the darkest in the black.

In lead pencil sketches the lowest tones are grey as compared with black, and consequently can not produce any decided depth. Crayon lithography is capable of producing beautiful soft greys. As the gradations from one tint to another are not continuous, the texture, consisting of innumerable minute dots, does not permit clear uninterrupted line work and even flow of tone. It does not lend itself particularly well to faithful copying from nature. The very character of its granulated line and surface suggests a sketchy and fragmentary treatment. Whistler, who, with Fantin-Latour, shares the honour of the happy revival of artistic lithography, readily realized this. He laid special stress upon the texture; its detached shapes creep over the paper like grey moss over a stone. They are all carried out in grey monotonous middle tints but marvellously delicate and subtle in values. Superficial but delicious in quality, his lithographic croquis impress us like the laborious trifles and harmonious bagatelles of a Herrick. 
Theodore Duret tells us that Whistler made his first series of six lithographs during the years 1877-78 (republished in 1887 by Boussod Valadon in Paris). They were drawn directly on stone, contrary to his later method, when he used transfer paper almost exclusively. They were rather large in size, and resembled his painted nocturnes in general treatment. This is particularly the case with his "View on the Thames," the most beautiful print of the series. I do not believe that these representations were of particular importance, as they contradict his own theory. What can be and has been perfectly expressed in one medium, can not reach equal perfection in another medium. It was really nothing but a translation of a painted nocturne into black and white. The essential charm of a Whistler nocturne consists of colour. Black and white can convey only a vague idea of vibrancy.

When Whistler took up lithographing for the second time in 1885-86, he had become thoroughly familiar with his medium. He no longer worked on the stone, and abandoned all elaborate finished compositions. His motifs are sketchy little figure studies, street scenes, portraits and occasionally a nude or semi-nude like his "Dancing Girl" in fluttering drapery. The printing he entrusted 
to a lithograph printer in London, Thomas Way by name, who was somewhat of an artist himself and consequently better equipped than the ordinary pressman to do justice to Whistler's vague fancies. Frequently Whistler took a hand in the printing, or at least made corrections. Printer Way told Mr. Wedmore, with reference to the sometimes disputed matter of the transfer paper, " that even when the artist drew on that in the first instance, and saw in proofs things that were lacking or things that were exaggerated, he would make his correction upon the stone itself, and so, of certain of his lithographs - his later ones especially - he produced different 'states,' though it was not easy to expressily define them, and though these differences were, of course, but the exceptions, and whereas very often, though of course not always in etchings - Whistler's or other peoples' - the earlier state is finer than the later; in these lithographs, generally speaking, the later state is finer than the earlier."

Whistler's lithographs can easily be classified according to the subjects they represent. During the years Whistler lived in Paris he depicted views and scenes of the city like the "Pantheon," "The Grand Gallery of the Louvre," "The Luxembourg Gardens" and 


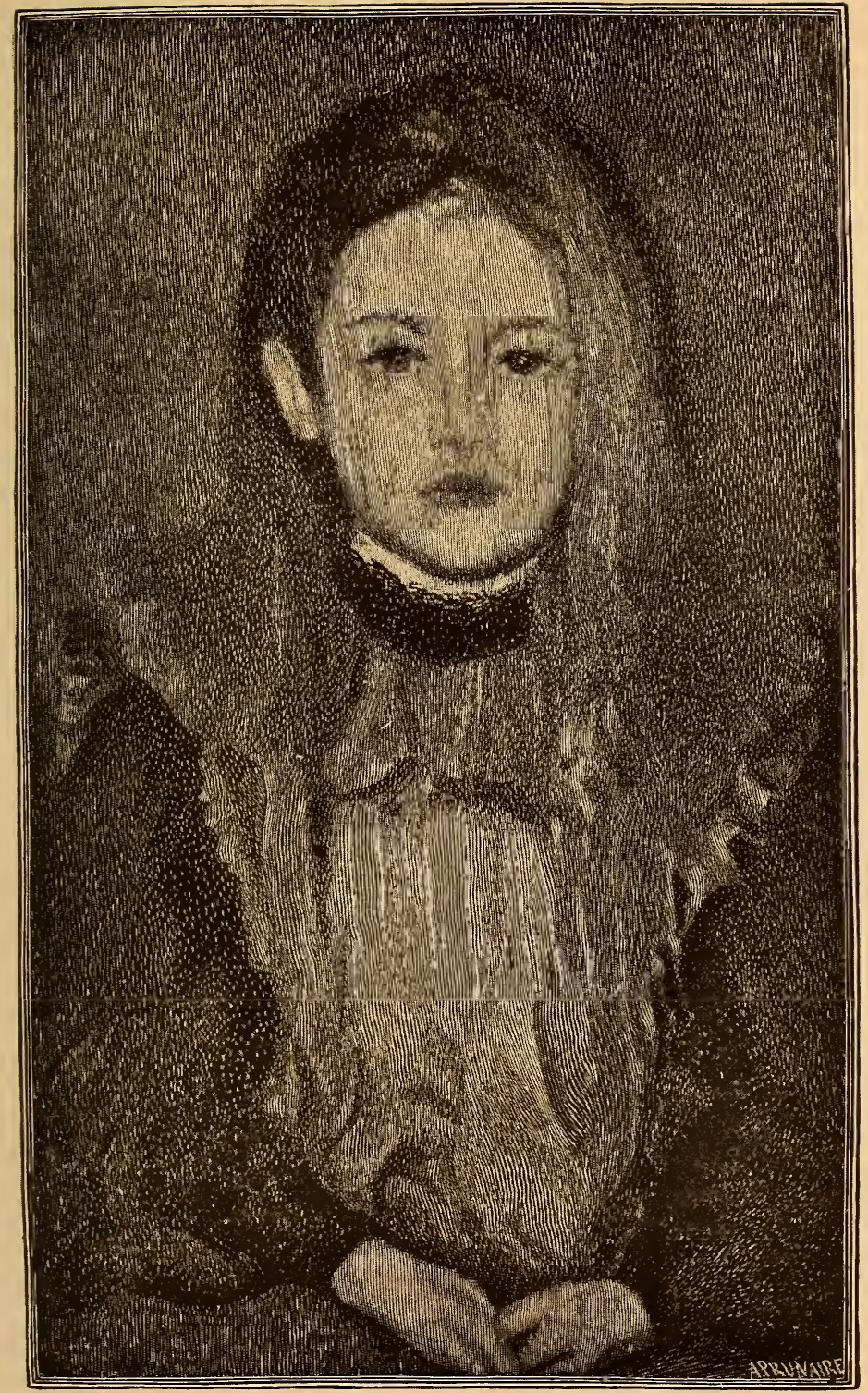

Boston Museum of Fine Arts

LITTLE ROSE OF LYME REGIS. 

interesting types like "La belle New Yorkaise" and "La belle Dame Paresseuse." One print, "Les Confidences dans le Jardin," depicts two gossiping women in the garden of his house in the rue du Bac.

His London subjects are equally numerous. In 1895, when he painted "The Master Smith " and the "Little Rose of Lyme Regis," while at a watering place in Dorsetshire he made several sketches of the picturesque streets of the old town. Of particular charm are his "Early Morning" (a view of the Thames from his Chelsea window) and "The Locksmith of the Dragon Square." In 1886, during an illness of his wife, he lived in the Surrey Hotel and executed a number of panoramic views of the Strand, the Thames with its river traffic, the quays, St. Paul's Cathedral and bird-eye views of London streets.

All these designs are beautifully enveloped in a misty atmosphere. The paper is used as a value as important as the grey lines of the crayon, and the forms are softened as if broken by light and generally massed in an unsymmetrical fashion.

Some of the portrait sketches are superb, in particular that of Stéphane Mallarmé, who was Whistler's life-long friend and one of his staunchest supporters. It was largely due 
to Mallarme that the "Portrait of the Artist's Mother" found a home in the Luxembourg. He also translated the "Ten O'clock" into French. Whistler's sketch of the poet appeared on the front of the Parisian edition of "Vers et Prose" (1893). It is apparently hurriedly dashed off, but the result of many careful studies and experiments. It is a mere fragment, negligent, disdainful; but how knowingly made, and how characteristic of the poet's personality! Despite its vagueness it is a likeness, and preferable, to me at least, who was fortunate to know Mallarmé in the early eighties, to most portraits made of him.

Whistler never surpassed this particular effort, although his portraits of Joseph Pennell, Mrs. Pennell, Walter Sickert, W. E. Henley and his wife, Miss Philip and Comte Montesquieu are excellent character studies. Way published in 1896 a catalogue of 130 lithographs. Later additions probably increase the number to 150 . The London Fine Arts Society held in 1895 a special sale of 75 lithographs. The "Grolier Club" of New York in 1900 held an exhibition of 106 prints.

His nudes are charming little inventions in pose and gesture with considerable knowledge of the human figure. In the Society exhibition of $\mathbf{1 8 8 5}$ he exhibited a nude entitled 


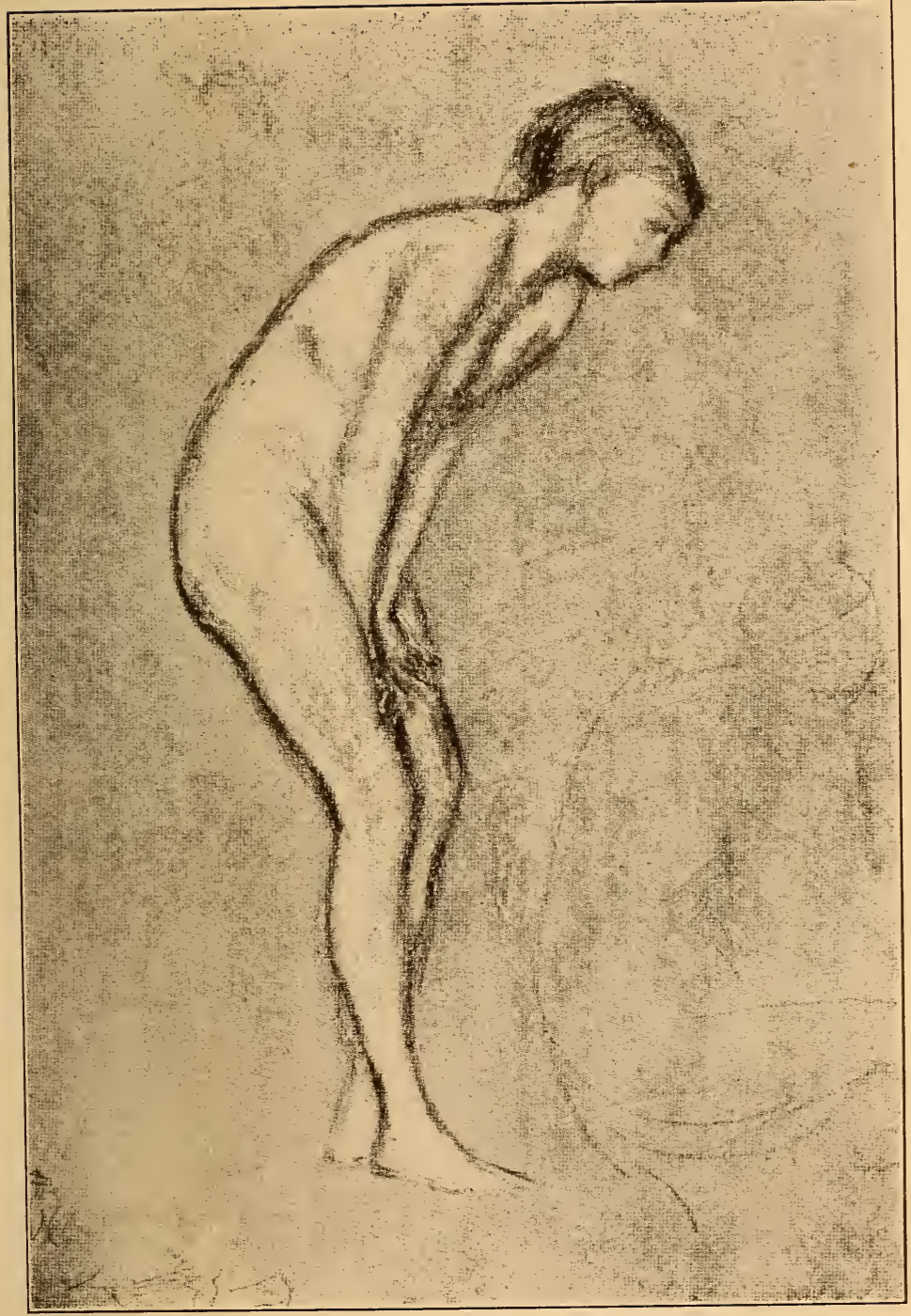

STUDY OF NUDE FIGURE (CHALK DRAWING). 

"Caprice." A $\boldsymbol{R}$. A. Horsley took exception to it, and in a lecture before a Church Congress, after indulging in most curious, pedantic and mediæval arguments, ended with the following tirade:

"Is not clothedness a distinct type and feature of our Christian faith? All art representations of nakedness are out of harmony with it."

Whistler, ever ready to take up the cudgel, avenged himself by writing under the picture: "Horsley soit qui mal y pense," and leaving it there during the entire exhibition.

Strange, that Whistler never attempted to paint a large nude in oil. $\mathrm{He}$, no doubt, had a reason for this omission, although it is nowhere recorded. Perhaps he agreed on the point with Ruskin that a realistic nude had no place in modern life, not for any moral reason but merely that the human body was too defective to allow the highest æsthetic gratification. A figure in modern garb is a part of modern life, a nude is an alien in space without any special significance. This should have appealed to Whistler; perhaps he strove hard to realize it but never succeeded in doing so. His lithographs and pastels of nudes seem largely experimental. They never go beyond the sketch and vaguely remind one of Tana- 
gra figures. "The Model Resting," and "The Little Nude Reading," a profile view of a young girl sitting in bed holding with both hands a book, are two of the best known.

Whistler also made a few attempts in coloured lithography, as for instance, " La Maison Jaune." But it is hardly coloured lithography, it is merely a black and white design with a few touches of colour, as expressed in "A Lannion" or the "Maison Rouge à Paimpol," the result of an excursion to Brittany. Perhaps the most exquisite and delicate of his efforts are these slight delicate renderings of female forms. When he adds a little colour it is always done with rare preciosity, the "un-finish" always being masterly. And there is such a thing as masterly "un-finish" always being just at the right spot as there is merit in the masterly inactivity of a Russian general opposing an invading army. The very essence of Whistler's art is to be seen in these coloured drawings.

Of peculiar charm are Whistler's pastels. The majority, some fifty which he exhibited in the London Fine Arts Society in 1880, depict Venetian scenes. They were catalogued as "harmonies in blue and browns, in opal and turquoise, etc." They show a rare elegance of design and a peculiar suavity of colour. They 


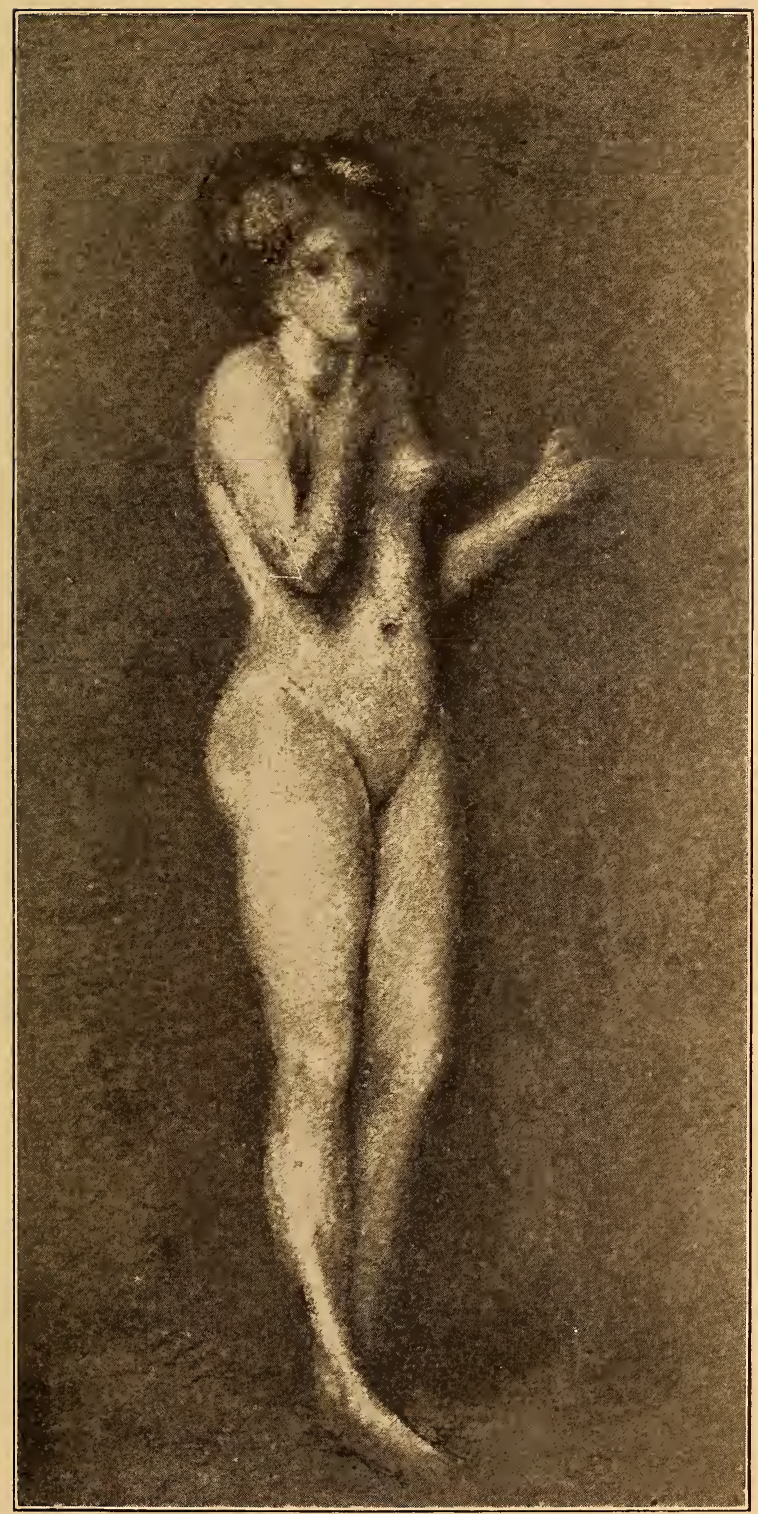

Owned by Th. R. Way

PASTEL STUDY. 

are the last remnants of his early period of vivid colouring, and are highly valued. They represent canals with draped gondolas, views from the lagoons with ships at anchor, archways, and white churches, the cemetery with green trees, lights gleaming on the distant shore and reflections in the water. His figures in pastels are mostly young girls, semi-nude or in quaintly coloured robes, frequently in pink and red against vague backgrounds. Whistler's virtuosity in these sketches and pictorial fragments is entirely different from the so-called impressionist's work. It is primarily full of imagination, of a high mental tone and dignity. Whistler has shown how noble an aspect can be given to the expression of an extremist, for he also was an extremist. $\mathrm{He}$ perfectly realized that aggressive sketchiness can never be monumental, that sketches are merely gymnastic exercises that lend health and strength to a painter's technique, although they remain to the end merely exercises. At the same time, if rightly handled, they express certain æsthetic aspects of life better than more elaborate efforts. He knew what a sketch could and could not convey, and the wonderful freshness and spontaneity which they exhibit are witness alike to the clear crispness of his perception and to his sympathetic handling. 
The only medium in which Whistler expressed himself without adding a decided note to individuality of execution, are his water colours. They have an easy flow, but the areas of surface seem too large for the slight treatment. The meaning of the motifs seems to be dissipated. They represent mostly street scenes, country views, the seashore and marines, charmingly translucent, but without suggesting a style, that developed the medium according to its resources. But whatever Whistler did was interesting. It is difficult to imagine a more delightful pastime than to look over a collection of his pastels, lithographs and aquarelles. They are carried out lightly, but with true touches of genius and joyous mystifying excursions into the dreamland of pictorial fancy, quite in the Whistlerian manner. No one, I think, quite so well fulfilled Whistler's own theory that an artist should see nature through the spiritual eye of an individual. Few painters were such frank interpreters of their own intimate moods.

Aside of all these works on record Whistler has scattered through the world countless scraps of drawings, themselves amply sufficient to make an artist's reputation. What a precious document we should have if their author were able to-day to give a list, as cer- 
tain artists have done, a kind of Liber veritatis of all the studies he has made and disseminated! But he has flung them far and wide, as the plum tree scatters its blossoms in approaching spring. 


\section{CHAPTER $\mathrm{X}$}

\section{WHISTLER'S ICONOCLASM}

IT would be difficult to find in the whole history of art writing another case of a pamphleteer who became as famous with a few manuscripts as Whistler. Both the "Gentle Art of Making Enemies," edited by Sheridan Ford, and published in 1890 by William Heineman, London; Frederick Stokes \& Co., New York; and Delabrosse \& Co., all in the same year, and "The Ten O'clock," delivered in London, February, 1885; in Cambridge, March 24th; and Oxford, April 30th of the following year, and published in 1888, created a sensation. They scarcely embrace five thousand words of reading matter.

Whistler's diction was exceedingly terse and poignant and he managed to say, or at least to suggest to intelligent minds, in a few words a phrase or maxim, which would exact from more sluggish pens page after page of argument. Of course, his letters and replies to 


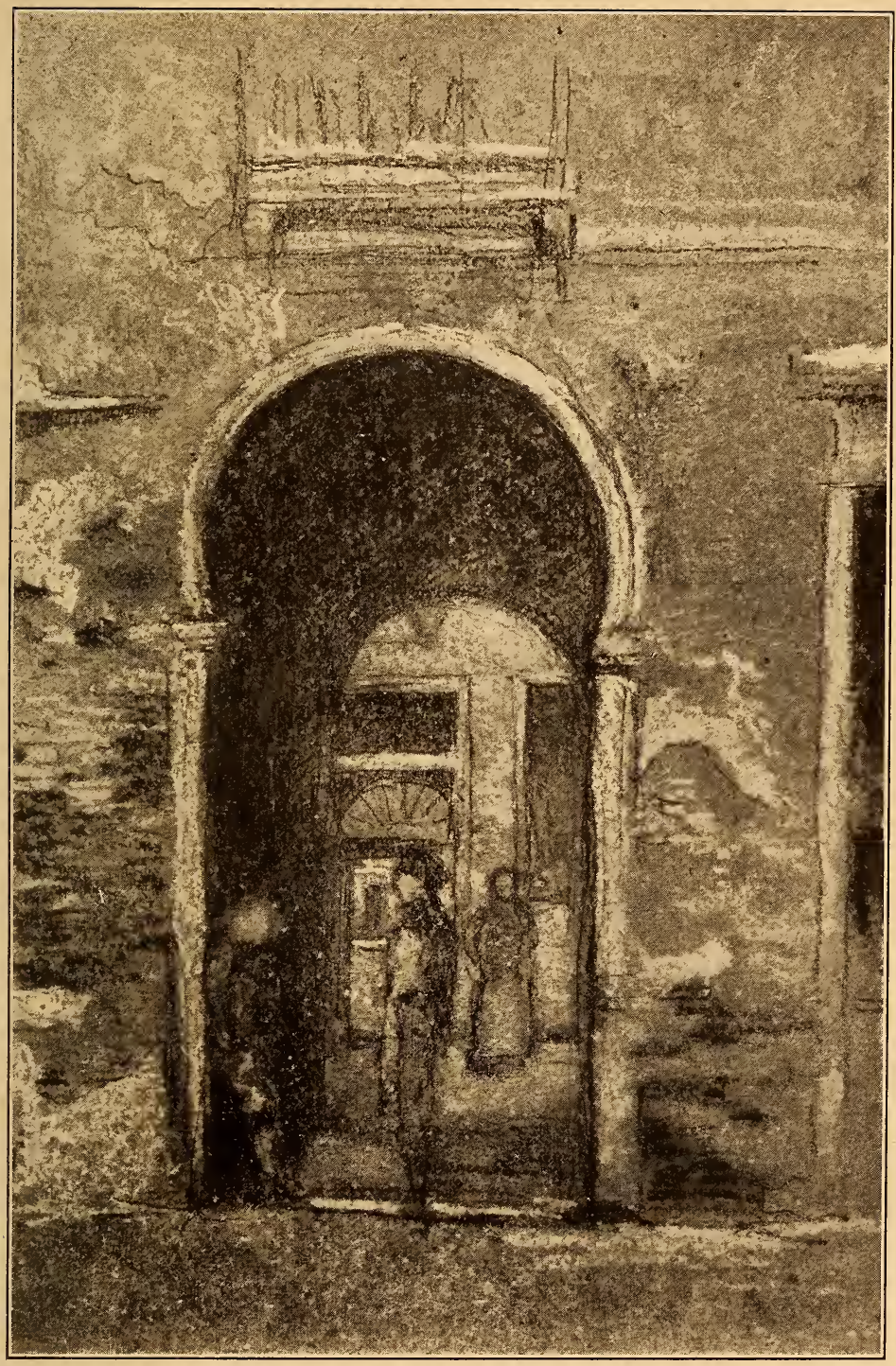

Owned by Howard Mansfield

ARCHWAY, VENICE (PASTEL). 

critics were written largely for effect. A well turned phrase was to him the ideal of diction and no doubt he rewrote every sentence a dozen times before he allowed it to go out to the public. It was to him a part - and a most serious part - of his profession. And whenever he did not deal with personalities and approached the technical principle on which his practice as artist was based, as in his "propositions," his observations and theories became lucid and convincing. Read his reply to the criticism which was caused by the withdrawal of two members from the Society of the British Artists, who left voluntarily knowing that changes of policy were inevitable under the presideney of Whistler. The attack in the London Daily News ended as follows:

"It will be for the patrons of the Suffolkstreet Gallery to decide whether the more than half-uncovered walls which will be offered to their view next week are more interesting than the work of many artists of more than average merit which will be conspicuous by its absence, owing to the selfish policy inaugurated.

(Signed) A British Artist."

Whistler answered:

"Far from me to propose to penetrate the 
motives of such withdrawal, but what I do deny was that it could possibly be caused - as its strangely late announcement seemed sweetly to insinuate - by the strong determination to tolerate no longer the mediocre work that had hitherto habitually swarmed the walls of the Suffolk-street.

"This is a plain question of date, and I pointed out that these two gentlemen left the Society six months ago-long before the supervising committee were called upon to act at all, or make any demonstration whatever. Your correspondent regrets that I do not ' go further,' and straightway goes further himself, and scarcely fares better, when, with a quaintness of naivete rare at this moment, he proposes that 'it will be for the patrons of the gallery to decide whether the more than halfcovered walls are more interesting than the works of many artists of more than the average merit.' Now it will be for the patrons to decide absolutely nothing. It is, and will always be, for the gentlemen of the hanging committee alone, duly chosen, to decide whether empty space be preferable to poor pictures - whether, in short, it be their duty to cover walls, merely that walls may be covered - no matter with what quality of work.

"Indeed the period of the patron has utterly 
passed away, and the painter takes his place to point out what he knows to be consistent with the demands of his art - without deference to patrons or prejudice to party. Beyond this, whether the " policy of Mr. Whistler and his following' be 'selfish or no,' matters but little; but if the policy of your correspondent's 'following' find itself among the ruthlessly rejected, his letter is more readily explained."

This is some logic and delicious sarcasm. It is to the point and there is nothing unpleasant in the entire argument. His art challenges and explanations always impress us in that manner.

That is why his art lecture, if it may be passed as such - it is exceedingly short as art lectures go - is so much more valuable as a literary document than his collected letters, though the latter are more amusing, and give perhaps a better insight into the author's personality. It is a concise résumé of modern art, not only the exploitation of one man's ideas, but rather a set of theories which reflect the thoughts of most of the younger and modern painters. It is written in a subjective way but the impression derived therefrom is objective. Whistler was one of the few great representa- 
tives of modern art, and if such a man has the gift to express his idea in a clear manner, a gift which most painters lack, he will necessarily reflect the aspirations of his contemporaries. As a piece of literature aside from the idea conveyed in it, I would compare it to Fromentin's " Le Desert," a charming treatise on colour and atmosphere, but as soon as it treats the more serious problems of art it becomes of deeper significance, and I, for my part, would not hesitate to mention it in the same breath with Lessing's "Laakoon." It has neither the dignity nor logical sequence of the Hamburgh philosopher, but the statements in it are more important, or at least, more significant to us than any theories of the German critic. I do not know of any book which is more reflective of modern art than Whistler's "Ten O'Clock." It filled a big gap, and its influence on the reasoning power (which, true enough, is small in many instances) of the modern painter has been far-reaching.

Whistler's literary activity began about 1863, when he lived in Linsey Row, London. His pictures had been rejected from several leading London and Paris exhibitions, and, finally, when he succeeded in exhibiting his "Woman in White" at the Berner Street Galleries, during the spring months of 1862 


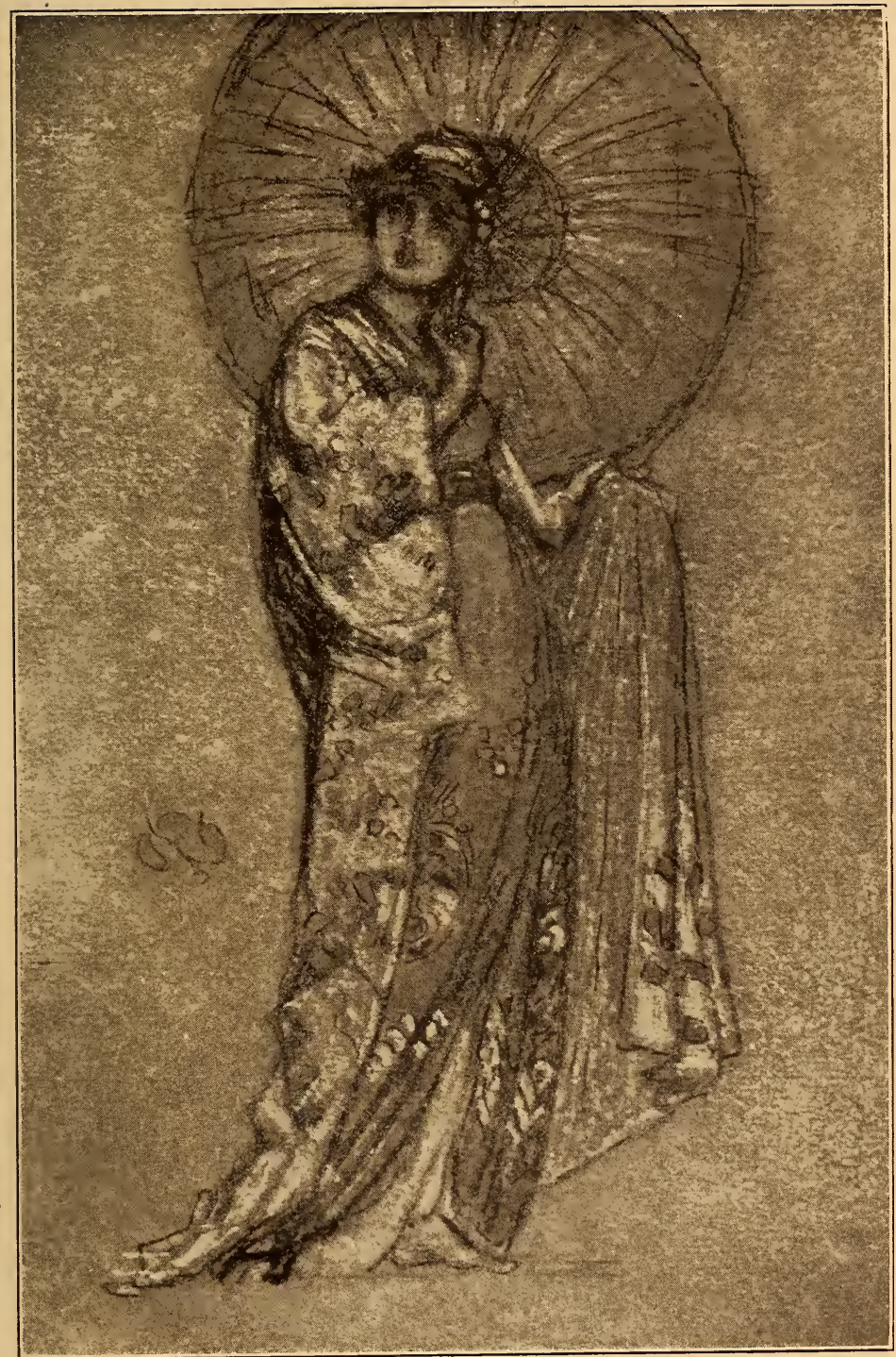

Owned by Howard Mansfield

THE JAPANESE DRESS (PASTEL). 

(before sending it to Paris), it called forth a storm of derision and ridicule. His answer to a most silly criticism in the "Athenæum," that the face of his "Woman in White" was well done, but that it was not that of Mr. Wilkie Collins' heroine was his first attempt at repudiation. It was as follows:

"May I beg to correct an erroneous impression likely to be confirmed by a paragraph in your last number? The Berner Street Galleries have, without my sanction, called my picture the 'Woman in White.' I had no intentions whatsoever of illustrating Mr. Wilkie Collins' novel; it so happens, indeed, that I have never read it. My painting simply represents a girl in white standing in front of a white curtain. I am,

JAMES W HISTLER."

The reply, in my mind, is rather commonplace. It has, as yet, nothing of Whistler's fine sarcasm and finished style. Almost anybody could have written it. The attitude of a critic to accept something as a starting point, and then to criticize a picture from that point, is such a commonplace occurrence that it was hardly worth answering.

Also his second literary attempt, more than 
ten years later, when he objected to having one of his pictures called "The Yacht Race: A symphony in B sharp," had little merit except that of indignation.

Whistler was an iconoclast, as fanatic as any, when problems of art were in question, but his image-breaking was always indirect, " inverted" as it were; he defended his position by asserting his own beliefs. He, no doubt, was prompted by his own deep-rooted convictions, but the stimulant of his literary activity was never based on didacticism: to bring out an idea because it was a great truth and ought to be brought out. The stimulant for his utterances was always personal anger, irritation and wrath. He fought for himself and his art, but not for others. He was one of the greatest egotists that ever lived. Whenever he felt hurt at some injustice and stupidity he had to set it aright, no matter at what cost, to his own satisfaction.

It was not before he was forty-four that he took up letter writing seriously. In one of his earliest answers he is seen at his best; it was written as early as $\mathbf{1 8 6 7}$ but never published until 188\%, when it appeared in the "Art Journal." Somebody had found fault with him calling one of his pictures "A Symphony in White," because one of the girls had reddish 
hair; and a yellow dress, a blue ribbon and a blue fan had been introduced into a white tonality. He replied in his vigorous fashion:

"Can anything be more amazing than the stultified prattle of this poor person? Not precisely a symphony in white ... for there is a yellowish dress . . . brown hair . . . and of course there is the flesh colour of the complexions. Bon Dieu! Did this creature expect white hair and chalked faces? And does he then in his astounding wisdom believe that a symphony in $\mathrm{F}$ contains no other note, but a continued repetition of F, F, F, F, F? ... Fool!

JAMES WhisTLer."

In this letter he took the right attitude, that of the fighter, who, with a few penstrokes, annihilated the foolishness of his opponents. If all his feuds had been of this character, no objection would have been raised to them. Alas, he did things, frequently, merely to pose as a wit, to say something that would make London society laugh, caring little in how malicious and vituperative a manner he would couch his words. Even when he was wrong and knew that he was wrong he would fight, as in the Café Orientale incident. A correspondent of the "World" attacked the title, 
stating that it had an $e$ too many for French, and an $f$ too few for Italian. Whistler does not attempt to justify his orthographical error, but, by telling an anecdote, endeavours to ridicule all criticism which pretends to such accuracy. It is cleverly told, but after all it is silly.

Nearly all his friends, sooner or later, were forced into crossing swords with him. The list is a long one and embraces many well-known names. He fought with his brother-in-law, F. Seymour Haden, because he had admired Frank Duveneck's etchings and mistaken them for Whistler's. He advised Harry Quilter, an art writer, " his bitterest enemy," to employ his sense of smell in preference to his eyesight; he calls the art critic P. G. Hamerton, "a certain Mr. Hamerton." He wrangled with Sir William Eden and even his friend Leyland about the price for ordered pictures, in each case making the whole transaction public; he attacked Tom Taylor and F. Wedmore for misquotations in their writings (he who had been guilty of the same thing himself), he quarrelled with the Academy when they repainted an old sign of his, "the famous Lion and Butterfly wrangle;" and wrote most insulting letters to Wyke Bayliss, who has succeeded him in the presidency. He withdrew 
all his pictures from the Paris Exposition, because the American colonel, C. R. Hawkins, had refused a few of his etchings in a rather impolite manner. The real reason was lack of space, and one could hardly expect from an American colonel the manners of a Chesterfield. Surely, Whistler did not possess them himself. He, at all times, practised more "manner" than manners, his language had at times an irritating touch of rudeness and coarseness. The feuds were endless. He continually baited his fellow artists. He called the pre-Raphaelites "What a damn crew." Legros, Val Prinsep, W. P. Frith, Sir Frederick Leighton and Dante Gabriel Rossetti, were at one time or another recipients. Everybody who came in contact with him, William M. Chase, "the masher of the Avenues," Theodore Child, who had to bear the brunt of a pun on his name, etc., all have some queer experiences to tell about him.

George Moore, who had stood so gallantly by Whistler's side, was thrown over without much ado as soon as he remained neutral, and did not join the front ranks of the fighting host in the Sir William Eden episode. Swinburne did not fare better; nor his friend Stott of Oldham, on whom he had passed such exaggerated eulogies in the beginning of his 
career. Even his oldest friend and supporter, Kennedy, the picture dealer, was finally bespattered with the mud of Whistler's invectives. His bon mots and repartee in ordinary life were as significant as those in his pamphlets, letters and catalogues. We all remember his "Why drag in Velasquez!" his " Goodness gracious! you don't fancy a man owns a picture because he bought it," or "Indeed! it is not every man in England I paint for." Then again talking about Leighton, "Yes, and he paints too." In meeting Du Maurier and Wilde at one of the exhibitions Whistler burst forth: "I say, which one of you invented the other, eh!" The famous repartee, Whistler:- "Nature's creeping up." Oscar Wilde: "Heavens, I wish I had said that!" "You will," dryly replied Whistler.

Most of his adversaries were smaller men or, at any rate, lacked the faculty of repartee, and for a witty man it was easy enough to mock them out of existence. Only Oscar Wilde, who himself made a profession of scattering corrosive epigrams, occasionally got the best of him. His sarcastic remark, "With our James, vulgarity begins at home; would that it might stop there," was one of the sentences that made Whistler lay aside his pen for a while and ponder on reciprocity. The famous 


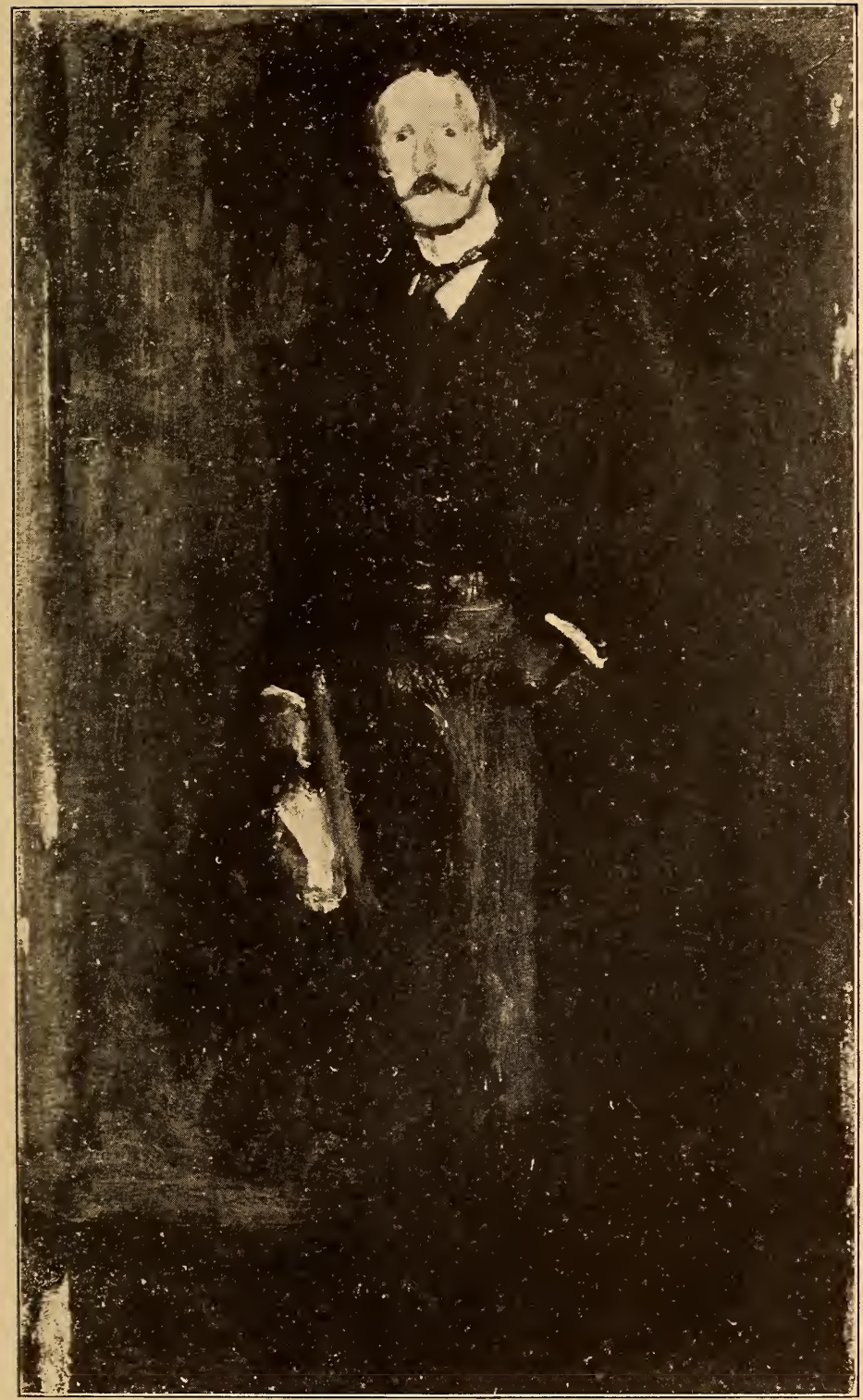

Courtesy of the Metropolitan Museum, New York MR. KENNEDY: PORTRAIT STUDY. 

Whistler $v$. Ruskin libel suit was gotten up, I believe, largely for effect. It happened naturally enough, but Whistler made the most of it. And, from the press agent's point of view, it was the opportunity of a life time.

In 1877 Sir Coutts Lindsey had organized an independent gallery in opposition to the London Royal Academy. Among the exhibitors were Burne-Jones, Millais, Leighton and Whistler. The works of the preRaphaelites were praised but Whistler's nocturnes were ignored or sneered at. He perhaps would have taken no notice of the ordinary criticisms, but when John Ruskin, who then was in the prime of his fame, wrote in his "Fors Clavigera," an art publication, a short and most obtrusive paragraph about the pictures, he put on his paint and feathers once more and went on the war path. It is incredible how a man like Ruskin could have ever been so bitter and pedantic, to write the following paragraph:

"Lastly the mannerisms and errors of these pictures (by Burne-Jones), whatever may be their extent, are never affected or indolent. Their work is natural to the painter, however strange to us; and it is wrought with utmost conscience of care, however far, to his own or 
our desire, the result may be yet incomplete. Scarcely so much can be said for any other pictures of the modern school; their eccentricities are most always in some degree forced, and their imperfections gratuitously, if not impertinently indulged. For Mr. Whistler's sake, no less than for the protection of the purchasers, Sir Coutts Lindsey ought not to have admitted works into the gallery in which the ill-educated conceit of the artist so nearly approached the aspect of the wilful imposture. I have seen, and heard, much of cockney impudence before now; but never expected to hear a coxcomb ask two hundred guineas for flinging a pot of paint in the public's face.

Joh'́ Ruskin."

The suit went to trial before Judge Huddleston and a special jury, November 25th, 1878, and Whistler won the case, although one farthing damages were allowed him. He published a small brown covered paper pamphlet: "Whistler v. Ruskin - Art and Art Critics," the same year. Not satisfied with his scant victory, he endeavoured to strike back at his still powerful adversary by publishing a hodgepodge résumé of Ruskin's writings and deliberately stringing together a number of well known sentences in such a way that they have 
no connection whatever. All this is amusing but smacks of the mountebank.

The Mortimer Menpes incident shows a different side of his nature. It was a controversy as to who was "the father of the decorative revolution," Menpes or Whistler. Intensely sympathetic with the work of Japan's great painters and craftsmen, Menpes' impressions of her cities, temples, shrines, theatres, gardens, and museums, received during a few months' stay in that land of delight, are worthy of consideration, but he had no claim to the decorative innovation, not even to the pink hue of his house, as Whistler had mixed the colour himself one summer afternoon, when Menpes was still his pupil. When a dispute was of real importance Whistler was apt to ignore it entirely, and let others fight it out for him. It was too serious a matter for exchange of witty remarks. This shows that Whistler, at times, realized the value of silence.

Even as there were friends and acquaintances and associates with whom he never quarrelled, he liked Carlo Pelligrini to the very end. He never picked a quarrel with Sarasate, nor with the Comte Montesquieu, though most people did. Charles Keene, the caricaturist, never writhed under Whistler's " strong arm." Even Sheridan Ford came out unscathed, al- 
though they were never on terms of "commonplace" amity and acquiescence. Nor did ever his American acquaintances advance to " warm personal friends." H. W. Singer says in his little monograph that "Perhaps Whistler's human soul was occupied by a double portion of malice, invidiousness and pettiness, so that his artistic spirit might be entirely free and unfettered in its greatness." As good an explanation as many others.

$\mathrm{He}$ wrote down those records he thought important as did Casanova his amours and Cellini his assassinations and, collected into a book, they form a sort of autobiography to those who can read between the lines. $\mathrm{He}$ had a way, as Pennell tells us, half-laughing, half-serious, of calling it his Bible. "Well, you know, you have only to look, and there it all is in the Bible," or "I am afraid you do not know the Bible as you should," he would reply to some question about his work or his experiences as an artist.

As remarked previously, his attacks were remarkably free from all personal and domestic references, they referred solely to art transactions related to the profession. Whistler was an artist, and naturally over-sensitive. $\mathrm{He}$ could not help being impatient of criticisms that utterly failed to see the aim of his work, 
sometimes praising him for qualities a painter would blush to possess and again heaping unmerited blame on admirable achievements. Things really irritated him and he worked himself into a white fury, often over nothing. Later on his love for notoriety and his pose made him exaggerate the importance of events. As in the case of every master, there were, of course, followers and disciples. To these, the master held forth, now instilling a principle of art, now relating an encounter with this or that critic. Mr. Menpes speaks quite truthfully when he says: "All the same, he was one of the true fearless champions that art ever had, he fought with the dignity of the artist, demanded consideration and courteous treatment, and upheld dignity of workmanship, never tired of exposing and exploiting the ignorance of the average press critic."

The real Whistler, then, as his closest friends saw him, was an impulsive, quixotic, erratic, if you like, but, above and beyond everything else, an artist of indisputable genius who fought a losing battle for a quarter of a century; jested through it all, and finally triumphed magnificently. His minor accomplishments were illumined by the flare of newspaper polemics; his greater and nobler qualities were too often obscured by the lack of com- 
prehension. Yet there were times when Whistler gave of his best simply and sincerely to all who had the perception to receive his gift. Such an occasion was that on which he delivered for the first time his immortal lecture on art, "Ten O'Clock." $\mathrm{He}$ chose this title because he did not want the people to rush to him from the dinner table, as to the theatre. Ten o'clock was early enough. The audience and critics who greeted him in Prince's Hall, London, on that never to be forgotten occasion, were puzzled by what they chose to regard as Whistler's " new pose." As a matter of fact, he was not posing at all, but had called them to him that he might impart to them, out of his very heart, the standard of artistic faith by which his life was ruled. It was a revolt not so much against the conclusions of modern paintings nor a plea for Japanese art (he does not mention Japan except once in the beautiful final sentence: "The story of the beautiful is already complete, hewn in the marble of Parthenon - and broidered, with the birds, upon the fan of Hokusai at the foot of Fusiyama ") as against the pedantic and realistic methods in art, a fierce crusade for the ideals of painting. His style is virile, individual, marvellously condensed and suggestive. It contains a number of beautifully put phrases like: "Art 


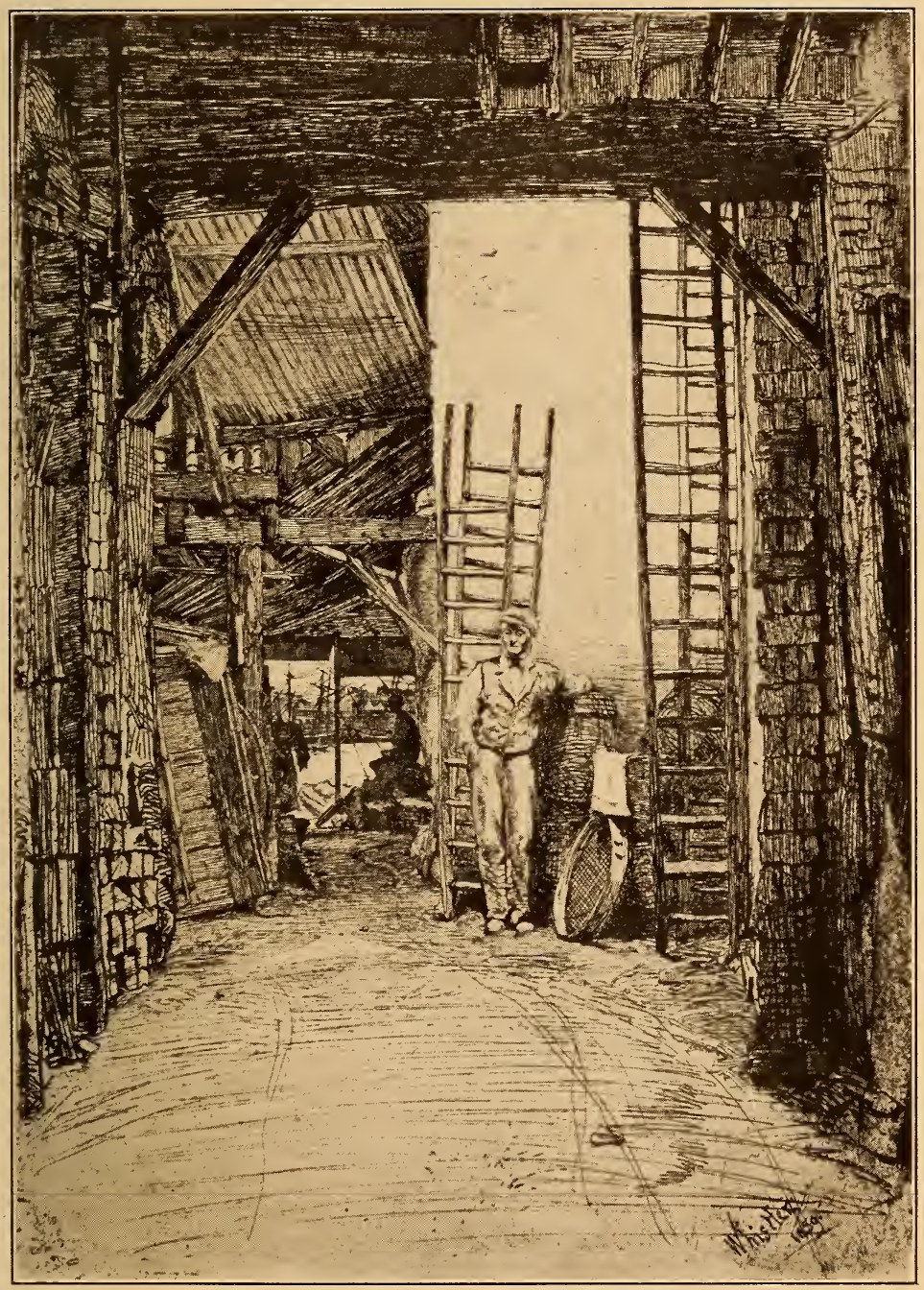

THE LIME BURNER (ETCHING). 

happens - no hovel is safe, no prince can depend upon it."

"Colours are not more since the heavy hangings of night were first drawn aside, and the loveliness of night revealed."

"If art be rare to-day it is seldom heretofore." In these aphorisms he puts his finger on the secret of literary expression - the application of the simplest and subtlest means to the most complicated and inexistent subject.

Paragraphs as the following must excite the admiration of every literary man.

"Alas! ladies and gentlemen, Art has been maligned. She has naught in common with such practices. She is a goddess of dainty thought - reticent of habit, abjuring all obtrusiveness, purposing in no way to better others."

"She is, withal, selfishly occupied with her own perfection only - having no desire to teach - seeking and finding the beautiful in all conditions and at all times as did her priest Rembrandt, when he saw picturesque grandeur and noble dignity in the Jews' quarter of Amsterdam, and lamented not that its inhabitants were not Greeks."

Or again:

"Humanity takes the place of art, and God's creations are excused by their useful- 
ness. Beauty is confounded with virtue and, before a work of art, it is asked: "What good shall it do?'

"Hence it is that nobility of action in his life is hopelessly linked with the merit of the work that portrays it; and thus the people have acquired the habit of looking, as who should say, not at a picture, but through it, at some human fact, that shall, not from a social point of view, better their mental or moral state. So we have come to hear of the painting that elevates, and the duty of the painter - of the picture that is full of thought and of the panel that merely decorates."

Whistler fought principally for three big ideas:

"That the main object of painting was to express the beauty of the technical medium unalloyed by any exterior motive, independent of time and place."

"That art was not restricted to any special locality, but universal, cosmopolitan."

" That art could be understood only by the artist and that all criticism consequently was futile occupation."

All these arguments have sifted down into the rank and file of the profession, they have become common property and are continually used in the every-day conversations of artists. 
They are all three open to criticism, and in a way (like all things, according to Walt Whitman) have done as much harm as good.

That the main object of art is art, cannot be confuted. But what is art in painting! Is all poetry and sentiment in a painting to be expressed by the actual handling of the colours, the process of handling and the mechanism of brushwork! Can all the poetry be contained in the objects themselves and the way they are painted? It has become the fashion of artists to say that they are painters, not artists.

Now what do they mean by this? What is a painter? A person who can handle the brush and who knows colour, or, in other words, who masters the tool of his trade. And what is an artist? The term artist is not limited to one profession. It applies to a musician or a sculptor as well as painter. In calling somebody an artist we mean to convey that he has a poetic conception in his work. But he must surely possess an equal mastery of technique or he would be unable to express it. And is the painter absolutely void of poetic conception? Surely not. He tries to get the poetry out of the medium itself, while the artist adds something from the outside to the medium. In that sense Abbott Thayer, Ryder and Inness are artists, Sargent and Chase are 
painters. But how about Chavannes, Whistler, Israels? I suppose they are both. There we are in a dilemma. They oppose subject painting; the beauty of the object, the poetry that is inherent in what they see before them, is supposed to be sufficient. But they object to the phrase that they are merely interested in surface beauty, they assert that they search for character and the inner meaning of things as much as anybody else. In this they contradict their own and Whistler's argument. Whistler himself was all his life a subject painter. Of course he has avoided telling stories, but he has suggested them, and given to each picture that vague note of interest which every true painting should possess. The main purpose is to make the picture more interesting. And you cannot make a picture more interesting without adding something. Painting for painting's sake is an impossibility. One cannot translate nature and life into colour without the help of the imagination. A little more or less, what is the difference?

The second claim, that all art is cosmopolitan, has been welcomed by all our ex-patriots, who have neither the strength nor the inclination to discover virgin material in their own country and to translate it into beauty. It furnishes a marvellous loop-hole for the imi- 
tative talent. Whistler said: "There is no such thing as English art - art is art when it is good enough." This is at its best merely a truism. We perfectly agree that only good workmanship makes a painting worthy of the name of art, but surely Hogarth, Gainsborough and Constable have a true native flavour in their work, which they could have gained nowhere but on British soil. All art, when perfect, can command universal appreciation, but it is perfect in most instances only when it has, perhaps not so much a local interest, but a local motive or stimulant, $i$. e. it must have inhaled the atmosphere of some peculiar locality and the faculty to exude it again. I believe, Whistler used his argument largely as a subterfuge, to hide his own enthusiasm for Japanese art. He understood how to amalgamate the foreign influences and his own individuality (this I have analyzed at length in some other chapter). His art in a sense was cosmopolitan, but merely because he was the first to adopt the new principles of an Eastern art; and it is just as easy to trace American as Japanese or Old Master traits in his work. I claim that all great art is local, and mention only three of the greatest painters, Velasquez, Rembrandt, and Dürer, to prove my argument. They surely were imbued with the 
spirit of their time and country. And I am equally certain that a painter who would express America as it is to-day (as Whitman has done in his time in literature) would be a greater man than Whistler. The foremost masters of the nineteenth century, Monet, Manet, Chavannes, and Whistler, were all innovators in technical problems, for they discovered new mediums of expression, and, in a way, only prepared the way for more concentrated expressions of art.

The third great theory of the essay, which consists largely of Whistler's arrogant assertions as to the superiority of the artist and his own hatred for so called connoisseur, dilettante, and critic, has made a very proud man of the painter. Imagine an ordinary wielder of the brush reading the following sentence: "Vulgarity - under whose fascinating influence 'the many' have elbowed 'the few,' and the gentle circle of Art swarms with the intoxicated mob of mediocrity, whose leaders prate and counsel, and call aloud, where the gods once spoke in whispers.

"And now from their midst the dilettante stalks abroad. The amateur is loosed. The voice of the æsthetic is heard in the land, and the catastrophe is upon us."

"The artist in fulness of heart and head 
is glad, and laughs aloud, and is happy in his strength, and is merry at the pompous pretension - the solemn stillness that surrounds him."

Whistler lashed himself into the belief that he was the sole judge of his work. This is a very erroneous attitude. Creation is an unconscious process. Few artists have the critical faculty to analyze their work, and years pass before he is able to get a clear view of his own work. If we were an art-loving nation things would be different, but interest in painting has become a privilege of the rich and of museums; it is too remote to be considered an immediate pleasure. It needs some kind intermediator to bring about more sympathy between the public and the artist. What writers, who can write and to whom the smell of paint is not unfamiliar, see in a picture, is one thing. What a painter desires to express is an entirely different proposition, but this is no reason to find fault with the writer. What he says may be explanatory and interesting. A work of art is made to arouse sensations, pure or æsthetic, emotions and vagrant thoughts, and they will differ vastly in every beholder. This may be beyond the pale of unattached writers and gentlemen clerks of collections and appointed preachers, into which 
Whistler has divided the critics, but there is no argument necessary to make any reader believe that authors like Hawthorne, the Goncourts, Guy de Maupassant, Paul Heyse, Mallarmé, knew how to write about art.

Whistler also laughed at the pretence of the state as a fosterer of art. In this he was right. Art can not be forced upon a community. It is a matter of individual appreciation. It is a matter of conquest.

But this is, after all, a busy world we are living in, and unless things are pointed out to us we may overlook them or not even learn of their existence, no matter how hungry we may be for new sensations. And that is the crucial point where the art writer may prove useful. The majority of artists entertain no kindly feeling towards art writers. In their just anger with critics, who arrogate to themselves the right of telling an artist how he should have done his work, they forget that the real writer on art, misnamed critic, has quite a different aim, and is their best friend. For he takes upon himself the duty of mediating between artist and public. Without him, we may say, the true artist is nowhere. True art (in opposition to commercial work and all vulgar practices to which pictorialism is put) is a difficult matter to comprehend. 
When the public, composed of people whose energy is drained almost to exhaustion by daily associations and occupations, suddenly encounters a new phase of art, it can no more formulate a just opinion of it than it could when placed face to face with the tablets of Karnak and Sakkarah. Just as the electrician in a new invention must explain the working of natural forces, so must the " critic" explain the work of the artistic forces which come into play in the production of a picture. Most artists have become popular - as far as the true artist can become popular - only after the eyes of the public have been opened by some critic. Such artists as find no apostle to proclaim their creed die unattended. Many an artist left his family in poverty; but after his death critics dwelt at length upon the beauties of his pictures, and only then the public began to pay enormous prices for them.

And Whistler himself! Does he not refute his own contempt by his Barnum-Boulangerlike use of the press? True enough all his little squibs and elaborate bids for notoriety had some underlying truth which he wished to express. But if ever an artist realized the power of type it was Whistler.

As for the ordinary critic - he deserves our deepest sympathy. He proves beyond dispute 
"that there is something rotten" in our art appreciation. Old Japan and the Primitifs knew them not. He is harmless, however, as he has absolutely nothing to do with art. $\mathrm{He}$ is a necessary evil produced by the shortcomings of the time. Anatole France's remark about art criticism, that it should be the adventure of one's soul among masterpieces, is enough, but he forgets that the adventure should be the experience of a literary artist. For the only criticism that is lasting is either biographical in tendency or artistic commentary, which by a new work of art reflects the beauty of the original. If a picture is really beautiful, one should be able to write a poem about it, or express it in music, dancing or some other art. 


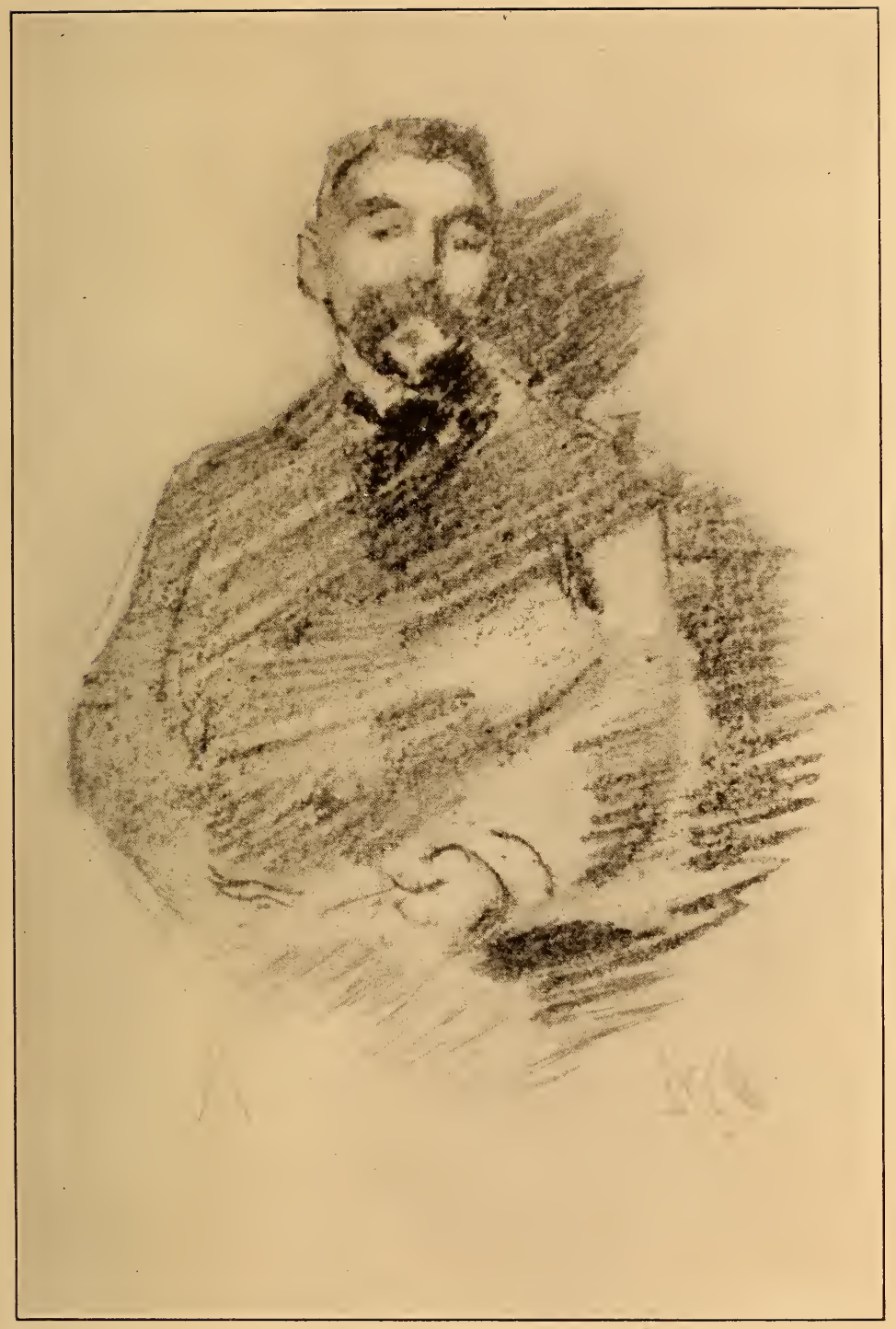

PORTRAIT OF STÉPHANE MALLARMÉ (LITHOGRAPH). 



\section{CHAPTER XI}

\section{AS HIS FRIENDS KNEW HIM}

ONE afternoon in 1892, walking along the boulevards with Stéphane Mallarmé, during absinthe hours, I met Whistler. The poet and the painter raised their hats and shook hands and exchanged a few words in French, which I did not understand. I was introduced, Whistler bowed, shook hands and then we passed on. It was one of those fugitive meetings that occur so frequently and to which no importance can be attached. It gives one the sole and rather futile privilege of having seen Whistler, just as I have seen Liszt, the king of Bavaria, Ibsen and many others, without having become acquainted with them.

I do not remember how Whistler was dressed, I only recall the top hat, monocle and cane. He looked rather undersized to me, a trifle affected, but exceedingly picturesque, and possessing that peculiar magnetism which we feel in the presence of great men. 
As for a more intimate analysis of Whistler's personality, I must refer to some of his friends, who have expressed themselves in print. I shall cite a number of paragraphs that have the merit of descriptive verity, and that will give a clear insight into his curious, highstrung character, as it appeared in every-day life.

"What strikes one in Whistler's biography," says Laurence Binyon, the London critic and poet, "is the extraordinary amount of time, trouble and energy he expended on things and people that did not matter, the record of his squabbles, the fanatical loyalty of his enmities, the rage of his 'egotism.' This is the Whistler that the world knew. But there was another Whistler, Mr. Binyon suggests, - " A man of singular sensitiveness, who shunned the vulgar daytime and stole abroad at twilight . . . bent always on revealing to his fellow men the loveliness that lurks in familiar sights and among the dingy aspects of a modern city."

One of his earliest intimates who writes of him in Vanity Fair, as one of the "Men of the Day," signed John Junior, says: "Mr. Whistler - 'Jimmy' as his friends call him is personally one of the most charming, simple and witty of men. He touches nothing but he 
embellishes and enlivens it with startling novelty of conceit. His hereditary lock of white hair is a rallying point of humour wherever he goes, and his studio is the resort of all who delight in hearing the new thing."

The article continues to say that it is evidently not difficult for the newspaper correspondent to approach him, as much had been written about his charming house and spacious studio in Chelsea. He was so thoroughly an artist that material seemed indifferent to him. His famous "Peacock Room," which he did for Mr. Leyland, shows his genius as a decorator, and conservative opinion is, that he was even greater as an etcher than as a painter. $\mathrm{He}$ had engraved, and painted in watercolours, of course, and his attire, from his topcoat to his shoe strings, was made from his own designs. Apparently he chafed under the academic tyranny of even the tailor. Of his powers in mimicry and in character acting his friend never tired of talking and telling anecdotes which illustrate it, and indicate that even in drollery his art is as subtle as in work of seriousness and dignity. "Dickens was not a patch on him," said someone, recently, who had seen the pantomiming of both.

Harper Pennington, one of his officially acknowledged pupils, gives a fine description of 
the man in the "Metropolitan Magazine" of 1910.

"Whistler was not a tall man, but of trim and muscular appearance, broad-shouldered, strong-armed, and well set up - the result of West Point training. He was intensely active and alert, although not in the least fidgety or nervous. His eyes were as bright as a bird's, flashing from face to face in a group of persons. It is noteworthy that he moved his eyes and not his head from side to side, fixing each speaker in his turn. This may have been another effect of West Point drills 'Eyes right,' 'Eyes left.' His long hands and bony wrists suggested force and delicacy of touch. If he was a trifle robin-legged, the effect served to enhance a certain dandified attitude he frequently assumed, especially when chaffing someone who deserved it, to the delight of the gallery, without which he seldom thought it worth while to perform.

"The man was above all things gregarious - he did not like to be alone - and most intensely human. He had his foibles, faults and virtues like the rest. The Whistler I knew was clean of person and speech. I never heard him utter one word that might not be repeated without offending the most easily shocked of prudes. He has been described as untidy. He 
was, on the contrary, the only man who ever washed his hair three times every day, and was fastidious to the point of being prinky about his person. His clothes, generally black, were always simple in the extreme and spotless, even when, in those old Venice days of dreadful poverty, they were worn threadbare - actually in holes. His courage was indisputable. He would fight any man, no matter what size or weight, and the jaunty cheerfulness with which he bore privations, when he lacked everything, even the materials necessary for his work, deceived those who were his daily companions and sufficiently proved his moral pluck.

"He wore a black silk ribbon tie at his neck, a bow with six inch loops and fluttering ends, but that was all that was unusual in his attire, unless the long bamboo wands of canes - a dark one for the night and a light for day should be included. Nothing that glittered, not even a watch-chain or a ring, formed any part of his costume. A tiny white or yellow flower at his buttonhole was his unique adornment.

"Is it true, as Thackeray declared, that ordinary mortals do, indeed, delight to pry into the weakness of the strong, the smallness of the great? I have thought it best to show 
my Whistler as he really was, a simple, kind and tender-hearted fellow, who turned his best. side towards the unappreciative world he lived in, not from vanity of person, but to hide his poverty, and the makeshifts he was driven to employ, as a man will say 'I like to walk,' when he can't afford to ride. His cackling laugh hid many a bitter thrust that had gone home and hurt him to the quick. $\mathrm{He}$ laughed, and then would come the swift riposte of witty repartee. He never attacked a living creature, never struck the first blow, and would have been glad to live in peace with all the world. But so coarse were the criticisms of his person and his work that he was driven to defend Art, which was the only thing he could not joke about. Upon the rare occasions when he talked with me, as a master might, about his work, his face itself seemed transfigured.

"Brave when he was well, his cowardice when ill or in pain was comical. If he caught cold he would disappear, and those who knew him well were sure he had fled to his doctor his brother's house in Wimpole Street. Dr. Whistler told me that Jimmy would appear all muffled up and say: "Willie, I am ill! I am going up to bed - here - and won't go home until you've cured me!' Any little malady was enough to demoralize him. In his 


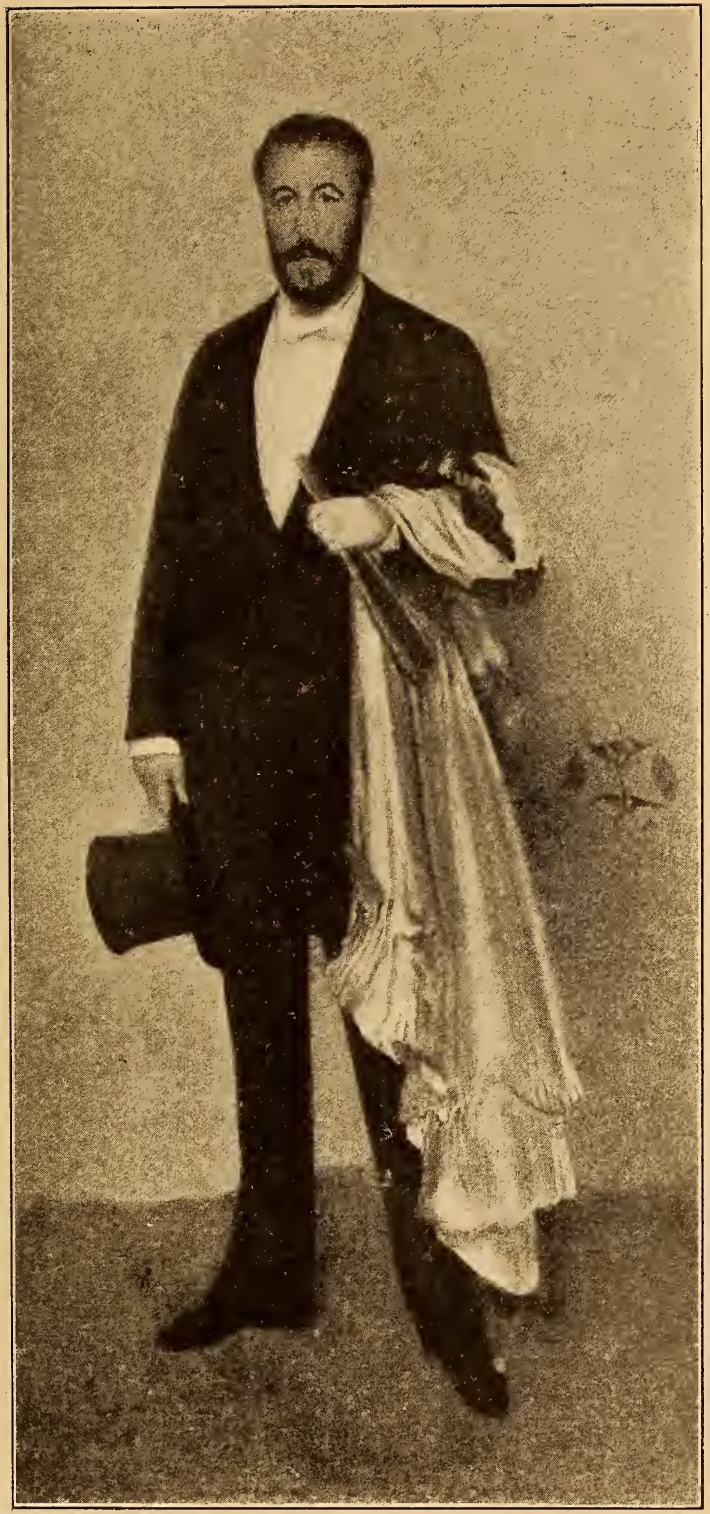

ARRANGEMENT IN FLESH-COLOUR AND BLACK: THEODORE DURET. 

hours of weakness he would hide away like a wounded animal and not show up again until he had been nursed back to his normal state.

"Whistler was extremely frugal and abstemious. He ate and drank most moderately the plainest fare. He liked dainty dishes and rare old wine, but had a horror of the 'groaning board' at huge set feasts and formal banquets. He could cook quite decently himself, and sometimes made an omelet or scrambled eggs, but these culinary feats I never saw performed; as to the Master's knowledge of wine, it was very limited indeed. I have seen him mistake a heavy vintage of champagne for 'Tisane.' I never saw him cook anything, even in his poorest days, in Venice, but I know that he liked a good dinner at a club even when it was punctually served and consisted of quite ordinary delicacies such as other men delight in."

The notes from his childhood are rather scarce. In his mother's diary, written during the stay in Russia, we find the following reference to him when he was twelve years old: “... Jimmie's eagerness to attain all his desires for information and his fearlessness often make him offend and it makes him appear less amiable than he really is." And at some other place, when they had watched some parade 
with the Empress passing: "He behaved like a man. With one compassing arm he guarded me, and with the other kept people at a proper distance, and I must confer, brilliant as the spectacle was, the greatest pleasure was derived by the conduct of my dear and manly boy." Miss Emma Palmer, his cousin, describes Whistler at this period as "tall and slight, with a pensive, delicate face, shaded by soft brown curls. He had a foreign appearance and manners, which, added to his natural abilities, made him very charming even at that age. He was one of the sweetest, loveliest boys I ever knew and was a great favourite."

"Whistler, as a boy, was exactly what those who knew him as a man would expect: gay and bright, absorbed in his work when that work was in any way related to art, brave and fearless, selfish, if selfishness is another word for ambition, considerate and kindly above all to his mother. The boy, like the man, was delightful to those who knew and understond him, 'startling' and 'alarming' to those who did not."

Joseph Pennell, in his excellent book, has given us a most fascinating description of Whistler as a student in Paris and a young painter in England. No one can refuse to admire the loyalty of this writer, who has gath- 
ered with such loving care every note of interest in Whistler's life. The following paragraphs are from his Quartier Latin chapter; "To Whistler the Frenchman was more sympathetic than the English, in his serious as in his light hours. His fellow students brought back to England the impression that he was an idler; it is hard to-day to make people believe that he was anything else in his youth. And yet he worked in Paris as prodigiously as he played. To us it is incomprehensible how he found time to read as a student, and yet he knew the literature of the period thoroughly, and always the charm of his manner and his courtesy made it delightful to do anything for him. Few men ever ate less than Whistler, but few were more fastidious about what they did eat - no man ever shrank more from thought, or at the mention of death than Whistler. There was always in life so much for him to do and so little time in which to do it.

"He was popular with the children, and delighted in music, though he was not too critical, for he was known to call the passing hurdy-gurdy into his garden and have it ground under his windows. Occasionally the brother (Greaves) played, so that Whistler might dance. He was always full of droller- 
ies and fun. He would imitate a man sawing, or two men fighting at the door, so cleverly that his brother never ceased to be astonished when he walked into the room alone and unhurt. He delighted in American mechanical toys and his house was full of Japanese dolls. One great doll, dressed like a man, he would take with him not only to Greaves, but to dinners at the Little Holland House, where the Princess then lived, and to other houses, where he put it through amazing performances." Many notes are quoted from the writings of his associates. Here are some of the most interesting of them: Mr. Luke Ionides writes: "He was a great favourite among us all, and also among the grisettes we used to meet at the gardens where dancing went on. I remember one especially, they called her the tigress. She seemed madly in love with Jimmie and would not allow any other woman to talk to him when she was present. She sat for him several times with her curly hair down her back. She had a good voice and I have often thought she suggested 'Trilby' to Du Maurier. One time in a rage she tore up a lot of drawings, when Whistler came home and saw them piled high on the table, he wept." If Whistler had money in his pockets, Mr. Ionides says, he spent it royally on others. 
Mr. Rowley, "Taffy," writes: "It was in 1857-8 that I knew Whistler, and a most amusing and eccentric fellow he was, with his long black thick curly hair and large felt hat with a broad black ribbon around it. I remember on the wall was a representation of him, I believe done by Du Maurier, a sketch of him, then a fainter one and then finally an interrogation - very clever it was and very much like the original. In those days he did not work hard."

"Whistler was never wholly one of us," Mr. Armstrong tells us; Drouet does not think that Whistler worked hard, certainly not in usual student fashion at the schools. He was every evening at the Students' ball, and as he never got up until ten or eleven in the morning, where was the time for work?

The personal observations and a glance at one of Whistler's self-portraits of this period should give us a fair vision of the young Whistler at Paris. The earliest known selfportrait in oil is the one painted in Paris about 1859, the Whistler with a hat, engraved by Guérard, which was lent by Samuel P. Avery to the Memorial Exhibition at Boston. It shows him with a slight mustache, a large Rubens hat, a big dotted tie, and a coat with a velvet collar. It is a good example of a 
dark silhouette against dark arrangement. The face has a few strong headlights, the remainder of it in middle tints, while the rest of the figure - the hat, the hair, the bust - are darker than the background. The space arrangement and position of the head are clever, but the shape of the bust is awkward, and, I fear slightly contorted.

Mrs. Jameson writes: " The man, as I knew him, was so different from the descriptions and presentations I have read of him, that I would like to speak of the other side of his character. It is impossible to conceive a more unfailingly courteous, considerate and delightful companion than Whistler as I found him, and I never heard a complaint of anything in my simple household arrangements from him. Any little failure was treated as a joke. His courtesy to servants and maids was particularly charming, indeed. I cannot conceive of his quarrelling with any one without provocation. His talk about his own work revealed a very different man to me from the self-satisfied man he is usually believed to have been. $\mathrm{He}$ knew his powers, of course, but he was painfully aware of his defects - in drawing for instance. To my judgment he was the most absolutely truthful man about himself that I ever met. I never knew him to hide an 


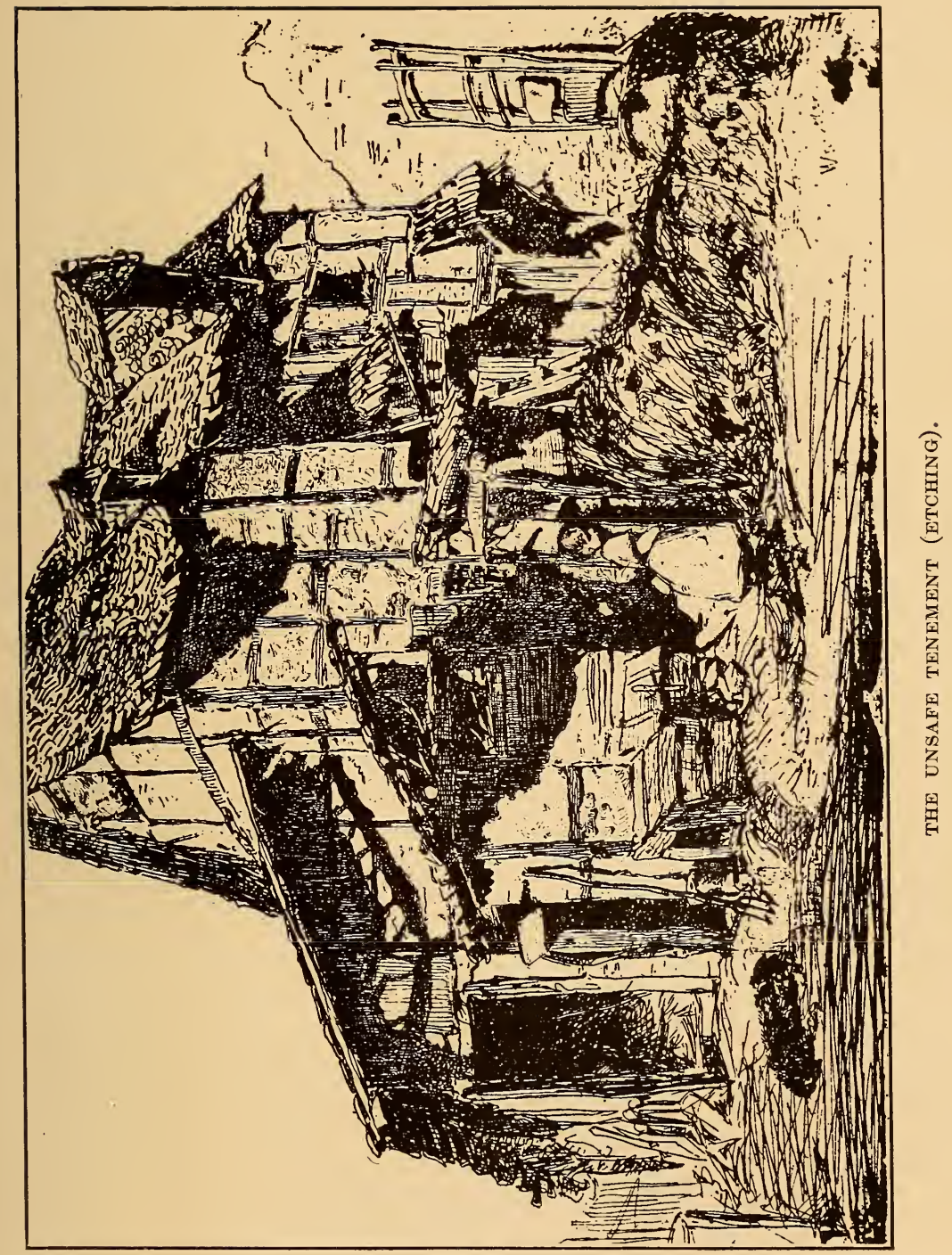



opinion or thought - nor to try to excuse an action."

Mr. Watts Denton, on the other hand, tries to make us believe that Dante Gabriel Rossetti got exceedingly tired of Whistler after a while and considered him a brainless fellow, who had no more than a quick malicious wit at the expense of others, and no real philosophy or humour.

Otto Bacher, the American painter and etcher, has written a delightful book entitled "With Whistler in Venice." The title is slightly deceptive as the contents are largely an eulogy on the beauties of Venice. Whistler is a mere picturesque incident. Bacher describes his friend in this fashion: "When he was talking the glass (monocle) was dropped. If he sat at one of the tables at the café the clanging of the eye-glass accentuated his conversation. If he was presented to any one it would drop and dangled to and fro from the neat cord for a few moments, to be readjusted after some moments of fumbling. His monocle was always a source of entertainment. $\mathrm{He}$ generally carried in his hand a Japanese bamboo cane, using it to emphasize his remarks.

"He rose early, worked strenuously and retired late. $\mathrm{He}$ seemed to forget ordinary 
hours for meals and would often have to be called over and over again. He was a fastidious smoker, but a continuous one - his choice of words was always a marked feature. His manners were elegant. $\mathrm{He}$ would always adapt himself to any situation and, at the same time, retain his dignity and personality."

Another interesting account was furnished in the Cornhill Magazine, 1903, by Mortimer Menpes: "Whistler was of all men essentially a purist - a purist in every sense of the word, both as a man and a worker. As a man he was sadly misunderstood by the masses. Whistler's nature was ever a combative one and his long and brilliant career was a continuous fight throughout. He revealed himself only to the few, and even that small inner circle, of whom I was one of the most devoted, saw the real man but seldom. But on those rare occasions Whistler could be gentle, sweet and sympathetic, almost feminine, so lovable was he. Whistler treated his hair as everything about him, purely from an artist's standpoint, as a picture, as a bit of decoration. Whistler wanted to produce certain lines in the frock coat and he insisted upon having the skirts cut very long, while there were to be capes over the shoulders, which must need form graceful curves in sympathy with the long-flowing 
lines of the skirt. The idea of wearing white duck trousers with a black coat was not conceived in order to be unlike other people, but because they formed a harmony in black and white he loved. His straight brimmed hats, his cane, the way he held his cane, each and every detail was observed, but only as the means of forming a decorative whole."

Less personal are Val Prinsep's remarks: "I have always thought that behind the ' poseur' there was quite a different Whistler. Those who saw him with his mother were conscious of the fact that the irrepressible Jimmy was very human. No one could have been a better son or more attentive to his mother's wishes; after his marriage I have heard that the life of this most Bohemian 'poseur' was most harmonious and domestic.

"The grammar of expression was a constant stumbling block to him, hence his slowness in producing. For let it not be supposed his pictures, which looked so simple in their execution, were produced with facility. The late Mr. Leyland told me that when he was sitting for his portrait, a standing full-length, Whistler nearly cried over the drawing of the legs and bitterly regretted that he had not learned something of the construction of the human form during his student years. He 
once spoke of himself as a 'soiled butterfly.' Surely this is the first recorded instance of a butterfly being an aggressive and vindictive insect. This however was a mere pose of Whistler's, the result of a well considered determination to exalt himself, which he found in the long run paid, even as all judicious publicity is said to bring in a sum percentage of profit."

A. Ludovici, a New York dealer, makes quite a hero of Whistler. " $\mathrm{He}$ soon made me feel that I was talking to an artist of great taste and refinement, full of love for his work and a ready wit, and, in spite of an academic training just received in Paris, I became that moment devoted to him and his art. The little I had seen of it at the Grosvenor engendered a desire to learn more regarding the mysterious technique of which he was such an undoubted master and confirmed my predilection in favour of painting the scene of life surrounding in preference to the making up of the conventional subject so much in vogue. I who knew him for the last twenty years of his life always found him most simple in his tastes, firm in his convictions, generous and openhearted to those whose friendship he relied on and always ready to help and oblige any one in whom his interests had been awakened. A 
more brilliant and staunch friend one could not wish to have had."

Also Alexander Harrison, the marine painter, expresses himself in a highly enthusiastic manner: "I have never known a man of more sincere and genuine impulse even in ordinary human relations and I am convinced that no man existed who could have been more easily controlled on lines of response to a fair and square apprehension of his genuine qualities. When off his guard he was often a pathetic kid and I have spotted him in bashful moods, although it would be hard to convince the bourgeois of this. Wit, pathos, gentleness, affection, audacity, acridity, tenacity were brought instantly to the sensitive surface, like a spark by rough contact."

Mr. Percy Thomas says: "He was a man who could never bear to be alone. Through his own open door strange people drifted. If they amused him he forgave them, however they presumed, and they usually did succeed. Whistler seldom painted men except when they came for their portraits, and the models drifting in and out of the door of Linsey Row, were mostly women. He liked to have them with him. Mr. Thomas thinks he felt it necessary to see them about his studio, for, as he watched their movements they would take the 
pose that he wanted, or suggest a group, an arrangement. He lived at a rate that would have killed most men, and at an expense in details that was fabulous."

Walter Gray speaks about Whistler's technique. "No one can realize who has not watched Whistler paint the agony that his work gave him. I have seen him, after a day's struggle with a picture when things did not go, completely collapse, as from an illness. His drawing coat gave him infinite trouble. Whatever his friends charge against him it seems to me that Whistler's faults and weaknesses sprang from an unbalanced mentality; he was a deséquilibré, the common defect of great painters. Yet, underneath all his vagaries and eccentricities, one felt that indefinable yet unmistakable being - a gentleman."

Pennell gives a most valuable description of Whistler as a painter. "The long nights of observation of the river were followed by long days of experiment in his studio. In the end he gave up even making notes of subjects and effects. It was impossible for him to choose and mix his colour at night, and he was compelled to trust his memory, which he cultivated, when he painted his nocturnes. $\mathrm{He}$ reshaped his brushes, usually heating them 


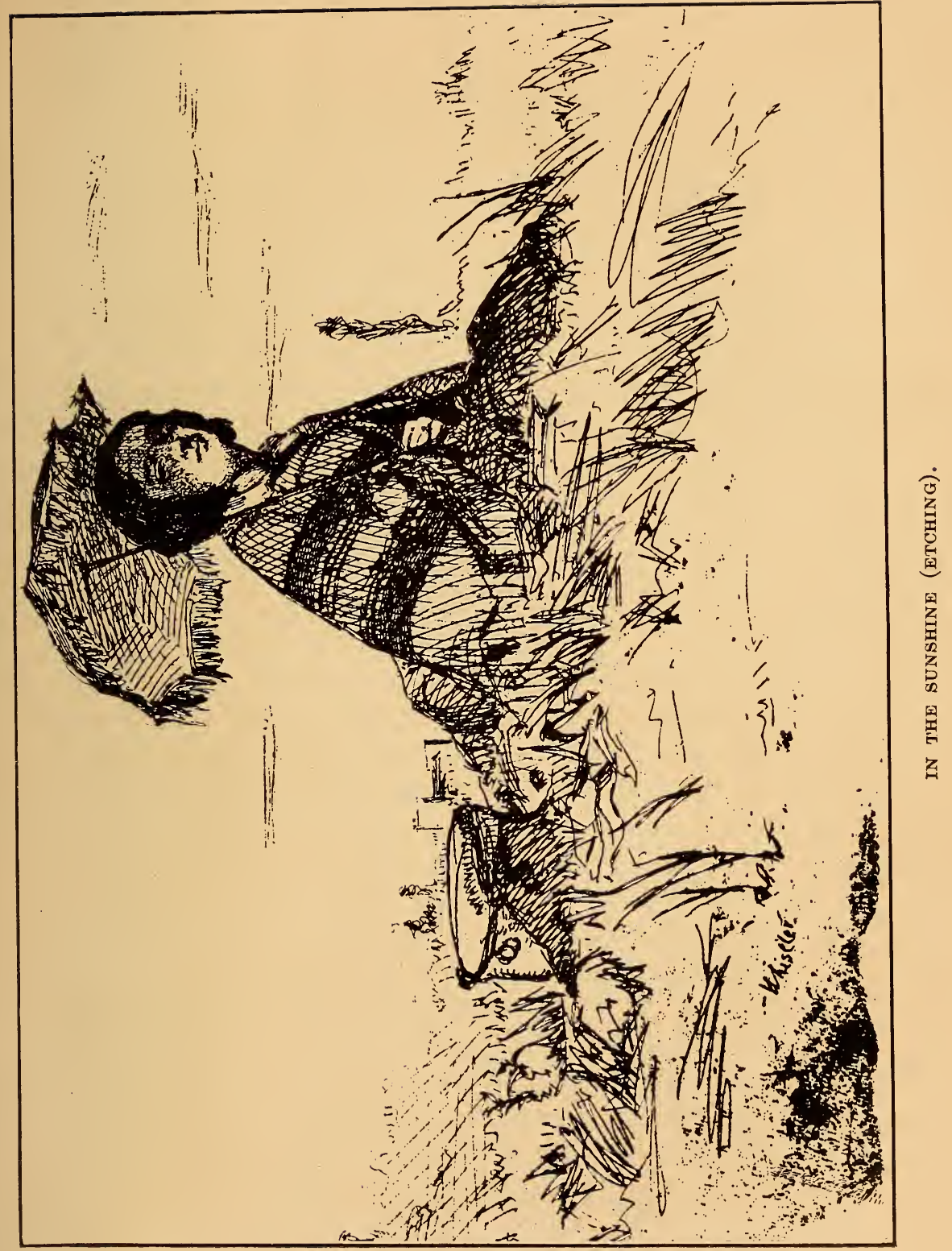



over a candle, melting the glue and pushing the hairs into the form he wanted. Whistler told us he used a medium composed of opal, mastix and turpentine. The colours were arranged upon a palette, a long oblong board some two feet by three with the 'Butterfly' inlaid in one corner; round the edge, sunken boxes for brushes and tubes. The palette was laid upon the table; the colours were placed, though, more frequently, there were no pure colours at all. Large quantities of different tones of prevailing colours in the fashion and his paints were mixed, and so much medium was used that he called it 'sauce.' Mr. Greaves says, that the nocturnes were mostly painted on very absorbant canvas, sometimes on panels, sometimes on bare brown holland sized. For the blue noctures the canvas was covered with a red ground, or the panel was of mahogany, which had the advantage of forcing up the blues. Others were done in a practically warm black ground. For the fireworks there was a lead ground, or if the night was grey - the canvas was grey.

"So much 'sauce' was used that, frequently, the canvas had to be thrown flat on the floor to keep the whole thing from running off. He washed the liquid colours on the canvas, lighting and darkening the tone as he worked. In 
many nocturnes the entire sky and water is rendered with great sweeps of the brush exactly the right tone. How many times he may have wiped out that sweeping tone is another matter. Some one remembers seeing the nocturnes set out along the garden wall to bake in the sun, sometimes they dried out like body colour in the most unexpected manner. He had no recipe, no system.

"In his painting it was surprising to see how much he accomplished in a short time. He would decide upon any local tone, putting it on with five or six big strokes, any variation of tones would be added in the same way. In a given time he would put down more facts than any man $I$ ever knew. In the beginning of a pastel he drew his subject crisply and carefully in outline with black crayon upon one of the sheets of tinted paper which fitted the general colour of the motives. A few touches with sky tinted pastels produced a remarkable effect. He never was in a hurry in his work, always careful and accomplished much. Every subject contrived some problem for nature which he wished to convey on canvas."

The portraits painted and etched by himself and various artist friends also comment favourably upon his personality. William Michael Rossetti, in his diary of February 5, 
$185 \%$, mentions seeing in Whistler's studio "a clever, vivacious portrait of himself," believed to be that belonging to the late George McCullough and which appears as the frontpiece to Pennell's book. Another portrait sketch of this period or a little later was shown at the exhibition at the Metropolitan Museum of Art in 1910.

Another portrait sketch can be seen in the Freer collection.

In 1874 Whistler planned a big picture similar to Fantin-Latour's " Hommage à Delacroix, only less serious and more eccentric in conception. Whistler was to be the centre figure and to be surrounded by the "Woman in White" on a couch and a kimonoed lady walking about the studio, while Albert Moore and Fantin-Latour were chosen to serve as black notes. One of the studies, Whistler in his studio, is illustrated in Pennell. A chalk drawing belonging to Thomas Way is likewise in the same book. There are three etched portraits in existence. A very early one dated 1859, the "Whistler with the White Lock," which appeared as frontispiece in Ralph Thomas' "Catalogue of Etchings and Drypoints of Whistler," and an etching very similar to the $\mathbf{1 8 6 7}$ portrait, dated $\mathbf{1 8 7 4}$.

In 1894 he was painting a portrait of him- 
self in a white jacket which, according to the Pennells, was changed into a dark coat after the death of his wife. A full length portrait in long overcoat was in the Paris Exposition of 1900, under the title of "Brown and Gold." Another half length is known to belong to George W. Vanderbilt.

A dry-point by Helleu, drawn in 1878, has many admirers, but is rather superficial as a characterization. The most important portrait is the Mephistophilean interpretation by Boldini, painted 1897 and shown at the Exposition in 1900. But I almost prefer a certain photograph which shows him with top-hat, and overcoat over his shoulder. It reminds me of the glimpse I caught of him that afternoon, in Paris years ago, when I was still carefree and had not the slightest idea that I would one day write a book about the man I passed so nonchalantly.

The few paragraphs that are cited in this chapter may not do his personality full justice, but they must suffice. A personality can not be recalled from the shades. We can only produce a mental image, and an abundance of notes would only confuse the outlines. His work remains, that is the principal thing. Even the greatest painters of the past are mere ghosts and visions to us. And although 
Whistler, more than any other modern painter, has the chance of marching down posterity, unforgotten and wreathed in glory, a curious high-seasoned personality not unlike Benvenuto Cellini, the author of these lines must refrain, as he can add nothing new or original.

Prophets or seers, call them what you will, in the arts or in the sciences, must of necessity be few and far between, and in advance of their age. Whistler is to me one of these, in his absolute and genuine love of his profession, for the resolve to win out at any cost, for his conquests in various realms of art and the triumph of ideas they represent.

I admire his colossal vanity and egotism, but, more than all, I admire him for the seriousness with which he took himself and his business of being a painter. It is so rare a quality. Velasquez was so much of a solemn cavalier that he was almost ashamed of being a painter. It offended him to be reminded of his profession. It was a serious sport to him, but only a sport. He was like Goethe: a distinguished and conscientious amateur. Their exalted position in life enabled them to treat art with such ease and condescension. But Whistler had to climb to the very heights from which they started, and all the battles and victories, struggles and temporary defeats, 
magnificent successes and lavish praises were the result of his personal efforts. Whistler needed, and had the true autolatry of the artist; he could conceive genius only under an artistic guise; he entertained the absolute faith that the faculty of painting is something so hugely superior to anything else that it confers a sort of sacred character on its owner. And it is for this wholesome artistic seriousness, this salutary egotism, that I admire Whistler, the man. 


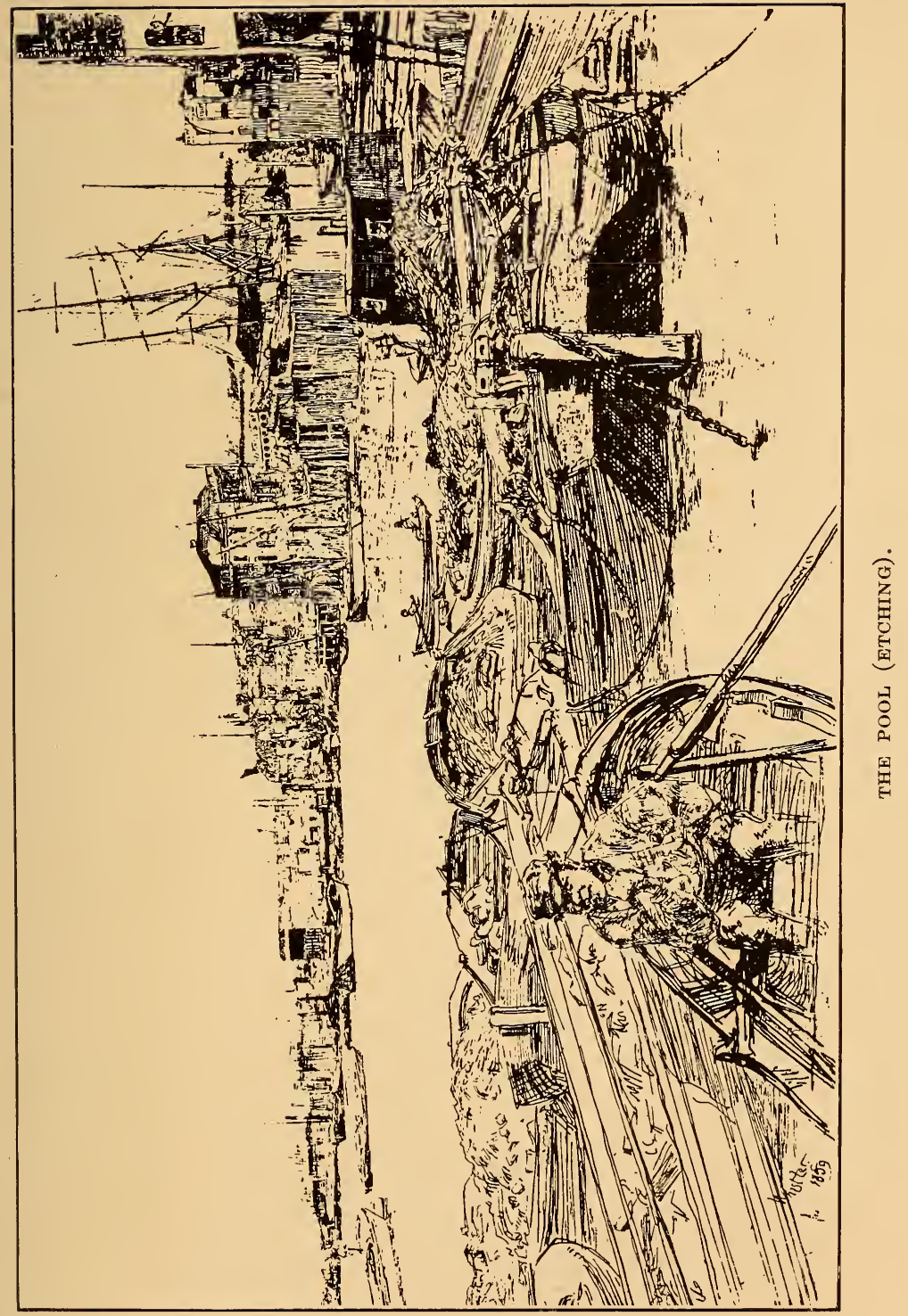





\section{CHAPTER XII}

THE STORY OF THE BEAUTIFUL

WHo knew the errant life of the highway, of the starlit desert and windy mountain slopes better than the story-teller of old, who wandered from town to village, from camp to solitary tent, all over the face of the earth, telling his simple tales to those who cared to listen? He was the wayfarer who lived in his life the Odyssey of the eternal Wanderer, and whose words reflected in quaint imaginative excursions the adventures of strange men and women he had met in lonely forests and crowded city streets.

Every nomadic tribe, every nation, every country, has had its singer of songs, its chanter of religious hymns, its troubadour, its vagrom poet, some story-teller of the beautiful. They have vanished, and the story is now repeated by the professional poet and artist. $\mathrm{He}$ no longer treads the highways and the listeners no longer offer him the hospitality of a night's shelter. He lives the life of the large cities; 
he hastens from place to place, he mingles with the crowd but passes unseen as nobody will listen to his stories. More than ever is he the vagrom man, unless he tells his story of the Beautiful in such a novel, fascinating way that Art, "the whimsical goddess," will open the book of life and inscribe his name. Then his townspeople, his nation, a whole continent, the entire world may claim him.

Whistler travelled many highways and lo, when he arrived at the age of sixty a weary, restless wanderer in the realm of art, three nations - England, France and America claimed him as their own.

Born in America, obtaining his education partly in America and partly in St. Petersburg, Russia, living the rest of his life in Europe, dividing his time almost equally between Paris and London, he was a cosmopolitan in the true sense of the word, and that is what he wished to be considered. He loved England and loved France, but he felt quite indifferent towards America. In Paris he had spent his student years, and he was drawn to this city by many bonds of attachments and friendships that lasted for life. And it was France who gave him that final great recognition of his genius when it purchased "The Artist's Mother" portrait for the Luxembourg, and 
made him an officer of the Legion of Honour. In England, on the other hand, he fought the great battles of his life for social as well as artistic recognition. In England he married, and was for many years one of the most conspicuous characters of London art and social life.

America really did nothing for him, and he did nothing for America. He never came back to America - during forty-eight years - after leaving it as a young man of twenty-one. He never exhibited in America until his name as a painter was one of the best known in Europe. $\mathrm{He}$ even preferred to exhibit his work with English artists in international exhibitions. We all remember the General Hawkins incident in 1889. Whistler only became known to America after his death through memorial exhibitions.

Now, of course, we like to claim him, and do so with ostentation. Expatriots are always claimed by their native country when they have achieved success or performed some remarkable act that has aroused the wonder of nations. Nobody cares whether Mr. Jack Johnson lived on the Place Monceau, or died on the Riviera.

To the analytical mind it is of little consequence whether he will go down in history as 
an American, English or Frenchman, as he was one of the great artists of the nineteenth century with an international significance. In the case of artists like Burne-Jones, Israels, Boldini, Fortuny, Lenbach, Segantini, it may be of more importance, as they are local talents.

Whistler's predilections were natural. $\mathrm{He}$ was too shrewd a promoter of his own artistic welfare not to make the best of this dispute of nations. He could not have prevented it anyhow, and the question of his nationality will be disputed for many years to come. Of course, one can simply settle the matter by saying that as he was born in America of American parents, he is an American.

The English differ; they choose to do in this case what we have always done with our immigrants. After a person has lived for any length of time in the country we make him a citizen and consider him an American. How about Carl Schurz, General Siegel and Roebling, the bridge builder? They were all born abroad and yet their names are inscribed on our roll of honour. Of what nationality was Lafcadio Hearn, who, born on the Ionian Islands, of Irish and Greek parentage, living for years in New Orleans and New York, finally selected Japan as the country of his choice, where he lived the remainder of his life and was buried? 
And yet we class him as an American writer. It seems that the party most concerned in it; the personality itself, should decide the question. Hearn wished to be considered a Japanese. We are not quite sure what Whistler's opinion was on the matter. He claimed to be a cosmopolitan. But that is no answer, as it does not settle the dispute. It leaves others to settle it, and the trouble starts anew.

There is another much subtler point, open to argument. Is his art in any sense American? Has it a flavour, a peculiarity of its own, that could be derived from any source except that of American birth and parentage? To this question I answer emphatically yes. True enough his subject matter was, with the exception of "L'Américaine" and a few portraits, strictly Continental. But the spirit was strictly Japanese and-American. Or, I would rather say, his form of art conception was Oriental, but the essence, the under-rhythm of his personality, was after all American. He was somewhat of a snob and a precieux, like his friend Comte Montesquiou. He had all the polished manners, the spirit, the grace of a foreign aristocrat and yet he was neither a Frenchman nor an Englishman in his habits or views on art. He remained an alien, as any man in a foreign climate must remain to some 
extent, when the change of domicile is made as late as the twentieth year.

His wit and sarcasm was American. It was not pointless, neither brusque nor frivolous but it was at times flat like Mark Twain's. His self-exploitation revealed the shrewdness of an intellectual Barnum. His attitude in society was that of a "Yankee at King Arthur's Court." Besides there are vague traits in his art which reveal the premises of his origin. His women, "The Fur Jacket," "Lady Archibald Campbell," "L'Américaine," and "Miss Alexander," have a natural finesse, direct grace and elegant frailty that can be found nowhere but in America. His power of adaptability, his disregard for ancient culture for modern purposes, his technical fanaticism, his adventurous tastes and theories, all have an American physiognomy. If there is anything that will make him an American it is the aptitude for labour, free association, and practical adaptation.

That he left America never to return again is no compliment to our country, but he, no doubt, acted wisely. If we remember the sad unsuccessful lives of Whitman and Poe, we shun to think what might have become of Whistler had he stayed on these shores. He, no doubt, would have become one of our best 


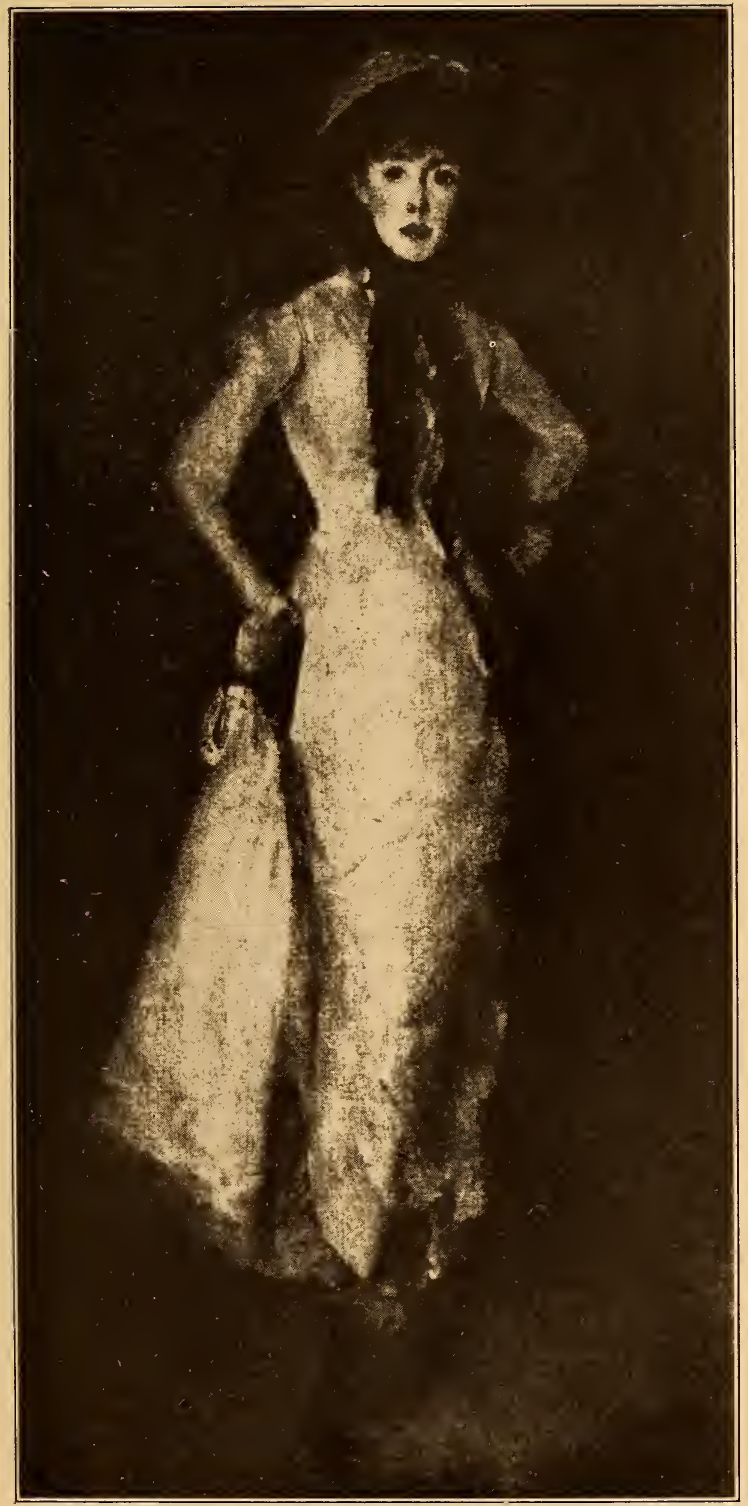

ARRANGEMENT IN BLACK AND WHITE: "L'AMERICAINE." 

painters, but he would never have become the Whistler we know to-day.

Like all our painters of merit, Fuller, Abbott Thayer, Winslow Homer, Homer Martin, to mention but a few, he would have retired into solitude, he would have become a hermit at a much earlier stage in his career. In England it was revolt, fight and victory; here it would have been stagnation. There would have been no fight because there would have been nobody to fight with.

When a man is young, he is strong because he is impulsive and because he has absolute faith in his beliefs. As he grows older his views broaden, he is not quite as certain of himself, and there will come a time when he will vacillate from one point to another, trying his faculties in different directions and searching for the final path on which his inborn talent may blossom forth in fullest strength and beauty. This is the time when a man needs encouragement, some patron no matter how stingy, some order no matter how humble, some friends and supporters who champion his cause - or he will succumb. He may not give up the battle, but his development will be marred and retarded for years.

American life is not particularly kind to budding geniuses, either in the period of revolt 
or of later evolution. There is no gainsaying we are a very material race just now. And it is nowise peculiar that it should be so. We do not expect much from Australia and Canada in the way of art. Why should we of the United States, where there are vast territories in very much the same primitive condition as in other emigrant countries? Of course there are certain parts and centres in this country which can boast of a culture dating back a few centuries, but the population has always lived in turmoil and conflict. Self-assertion and self-improvement are the ideals of any man who has changed his domicile, in the one hope to better his material welfare. In a country which is so vast as ours and which has at times an increase of ten thousand aliens a week, the national pride in intellectual accomplishments cannot run high.

All that wealth can do is done at present. We have numerous private collections of rare excellence and will have National Galleries and Kensington Museums in due time, but, as Whistler has said, art is not a matter of education, or of royal, civic or municipal encouragement. It is a growth and the soil must be ripe for it. No doubt, in due time collectors will divert some of their attention from the battered relics of past ages to the quite as 
admirable productions of their contemporaries. It would be pleasant to find that people cease the worship of dubious pictures by Old Masters as the one certain and infallible proof of enlightment.

The artist of to-day has to subsist on the Spartan principle; he has either to do or to die. These are no stimulants to inspiration. $\mathrm{He}$ has to dig it all out of himself. That engenders martyrdom. And very few, particularly those equipped with lesser talent, are willing to give up a half-way respectable existence for a life in a garret and a long wait until fame knocks at the door. Nearly all the great European artists had their struggle and lived in hovels. The American is less willing to enter upon such a precarious existence, as he realizes that if he accepts it, he may have to stay in a garret until the end of his life. American artists do not assist each other. Each goes his own way, partly under the stress of conditions, because the vastness of the country and larger towns permits no closer association; and partly by choice, by personal inclination or professional reasons. There is but little intellectual intercourse. The atmospheric conditions are just as beautiful here as anywhere. And so are the subjects equally beautiful and plentiful. It would be ridiculous to deny it. Yet 
it takes courage to be a pioneer. It needs leisure, some incentive and sympathy. No man is inexhaustible. He needs some encouragement from outside; and if it fails to come he will grow indifferent. He may open up a restaurant, or become an illustrator on a comic paper. Deserters of this kind may not represent an irreparable loss, as they were never ensign-bearers, nor ever stood in the firing line.

"They were not carved as from iron or wood, Cut with an axe, or hammered with sledge, Till the man shows strong and good."

as Daniel Dawson sang, another young poet who fell by the wayside.

Our conditions are not conducive to the evolution and exploitation of a genius. Graft and prohibition laws, whose evil influences are felt in all strata of society, also injure artistic progress, if not directly, surely by the stress of public opinion. Such conditions would no doubt have retarded the progress of even a man like Whistler for years. If a man has not the means to sip his demi-tasse at Florian's, in Venice on the piazza, he can not make any etchings or lithographs of the Campanile. And if a man cannot afford to buy plates and an etching press he cannot make any etchings 
at all. And that is the fate of hundreds of artists in our larger cities.

No, to go to Paris and then to find another congenial abode in Europe, to settle there, to live his own life, and to do in art what he wanted to do was the wisest move Whistler ever made. It helped him to expand and to mature the great talent that was slumbering within him, ever since he stared, lost in wonder, at the Velasquez of the Hermitage at St. Petersburg.

Whistler admired the Greek as much as anybody, but this emotional reverence did not hinder him from smashing some traditions of ancient beauty to pieces. Greek art was so perfect that for centuries no artist could escape its influence. All the Old Masters were nursed on the marble breasts of Grecian goddesses. In all art schools the white corpses of plaster cast facsimiles were worshipped on bended knee. The pupils never dared to glance about. They did not see the beauty of the world around them. They could perceive it only through Greek conventions. This had to cease. There was no life blood in these artificial constructions. But tradition was so deeply ingrained in Western æstheticisms that it lingered on for centuries, until Manet entered the studio, opened the windows, 
let in the light, and Monet took the young students by the arm, pushed them into the open air and led them to the meadows and riverside, and the open road.

Whistler, in the meanwhile, had scoured the whole horizon of art, and beheld a new dawn in the East. There he saw an old civilization, as deep and broad as ours. It was just at a stage when modern materialism had begun to wash out some of its finest colours. Art was deteriorating in the East under the stress of missionaries and merchants. An era of manufacture had set in. Could not the noble, unselfish spirit of old Japan be kept alive, revived, - amalgamated with our art, and be made to pour new life into our valiant dreams of beauty!

You remember what Whistler said of the primitive artist. The words are worth repeating:

"In the beginning, man went forth each day - some to do battle, some to the chase, others, again, to dig and delve in the fields all that they might gain and live, or lose and die. Until there was found among them one, differing from the rest, whose pursuits attracted him not, and so he stayed by the tents with the women, and traced strange devices with a burnt stick upon a gourd. 
"This man, who took not joy in the ways of his brethren - who cared not for conquest, and fretted in the field - this designer of. quaint patterns - this deviser of the beautiful, who perceived in Nature about him curious curvings, as faces are seen in the fire, this dreamer apart, was the first artist.

"And when, from the field from afar, there came back the people, they took the gourd and drank from out of it.

"And presently there came to this man another - and in time others - of like nature, chosen by the Gods - and so they worked together and soon they fashioned from the moistened earth forms resembling the gourd. And with the power of creation, the heirloom of the artist, presently they went forth beyond the slovenly suggestion of Nature, and the first vase was born, in beautiful proportions.

"And the toilers tilled and were athirst; and the heroes returned from fresh victories, to rejoice and to feast; and all drank alike from the artist's goblets, fashioned cunningly, taking no note the while of the craftsman's pride, and understanding not his glory in his work; drinking at the cup, not from choice, not from a consciousness that it was beautiful, but because, forsooth, there was none other." 
The art of the past has done its work. The white gods are worshipped no longer in the sacred woods and the Old Masters have lost much of their spiritual glamour. But no need to mourn their loss, they will remain beautiful. We will always look with awe and wonder at the figures of the Parthenon frieze. We will never cease to love the Primitifs. We will continue to make pilgrimages to the Prado and the Sistine Chapel. And Rembrandt will as heretofore receive the adoration of mankind.

Yet the new art will be different. It has to be different to equal the old. It will be attuned to the moods of the modern mind. It will have new accents. It will bear the analytical and complex aspects of our time. It will be subtler, more fragile, perhaps, but it will drive deeper into our soul than the cold correctness of older forms and emblems.

It was Whistler who pointed out that a large picture is a contradiction, that a picture like Raphael's “Transfiguration" or Veronese's "Marriage of Cana" are merely combinations of smaller pictures, drearily linked together by stretches of negligible paint. The demands of explanation, of form and composition, drag in, every now and then, lines and colour notes which are merely padding. They are the painter's concessions to the old rules of com- 


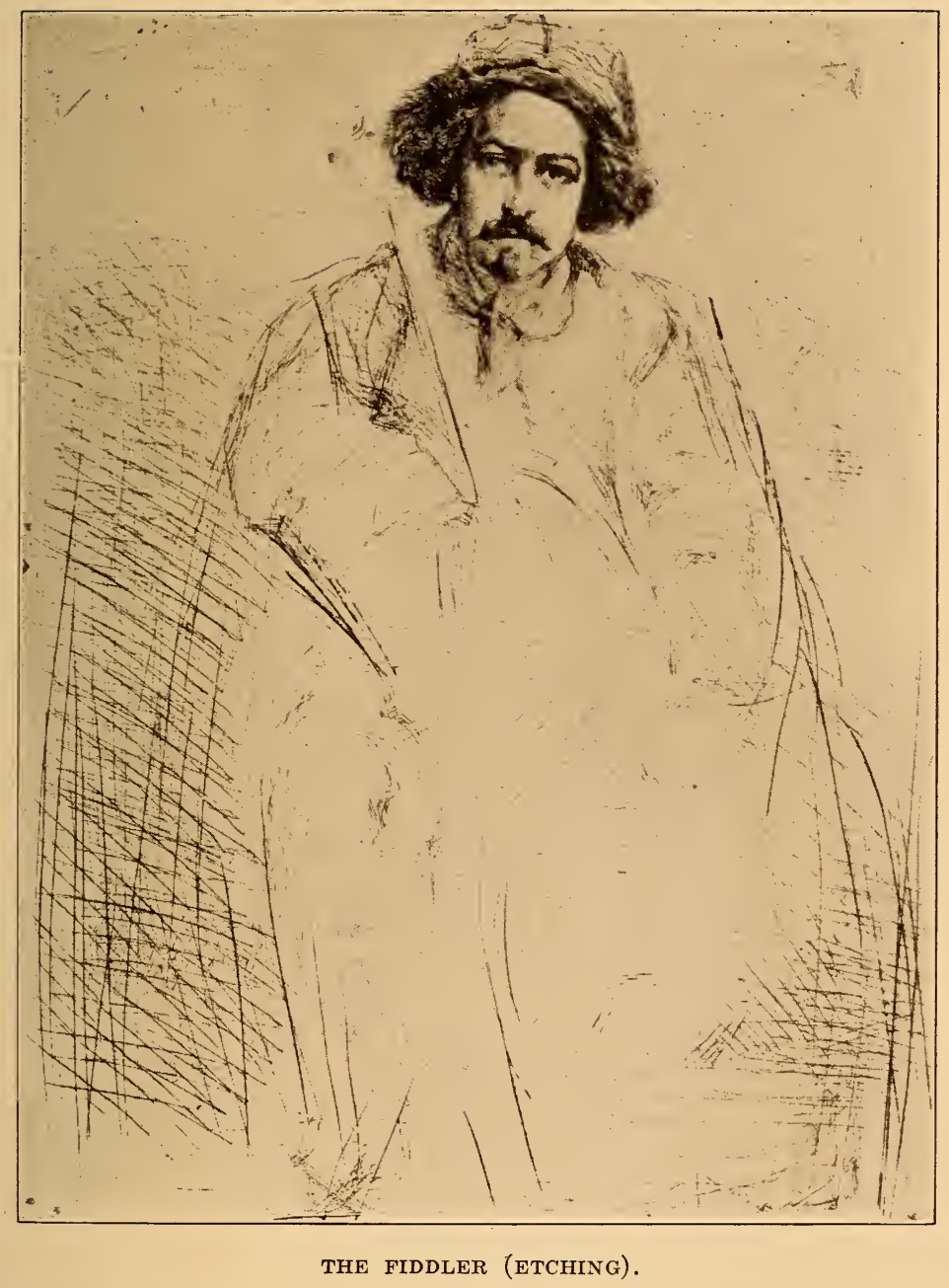



plexity. The modern mind demands a concentrated vision. Painting must appeal again directly to our finer sensibilities, speak to us without interference of moral or literary considerations.

It was Whistler who taught that painting was a science of colour manipulation. That the first requisite of a painter is to know how to paint. Everybody can learn how to draw and how to handle a brush. To explore the secrets of colour, to discern their influences upon each other, to render them atmospheric and musical, that alone is of vital importance. For painting should be a visual language that speaks directly and distinctly to the cultured mind. How many of the younger American painters (alas, our younger men have all passed the threshold of thirty if not of forty) really know their metier? Henri, Reid, Luks, Tarbell, Hawthorne, Clews, R. E. Miller, Lucas, who else? That is why Whistler's art is so exceptional and masterful. There may be other methods just as good as his; Monticelli, Maris, Mancini, Segantini, Renoir, Cézanne, etc., all have their peculiar way, but I believe that Whistler got nearest to the pulse beat of our age. Resolutely and tranquil, he carried an idea to its utmost logical conclusion, after once accepting its particular point of view. And 
that is why everything he did bears an unmistakable stamp of his own.

It was Whistler who proved that art was synonymous with hard work. Few painters will follow his example and spend a whole day trying to put in a high-light or to find the right place for a butterfly's wing, and go home at night satisfied with having made a few brushstrokes after altering them a hundred times, but these commercial travellers of art will never know the painter's pure delight, the contemplation of life, the aspiration to perfection, the lifting of beauty out of the dead pigment. Such worship of art, such absolute disinterestedness, such fidelity to painting cannot be too highly esteemed.

And it was Whistler who proclaimed that art cannot be taught but must be an inborn gift, that everything can be acquired by long practice save that one supernatural quality of genius which alone can transform a painter into a great artist. What is there in these pictures produced every year, here and in Paris and everywhere? Portraits, landscapes, ordinary delineations of prosaic scenes that may be painted with considerable skill and that may look pretty enough, but that are absolutely incapable of evoking a fine and subtle emotion. This, the men upon whose shoulders the black 


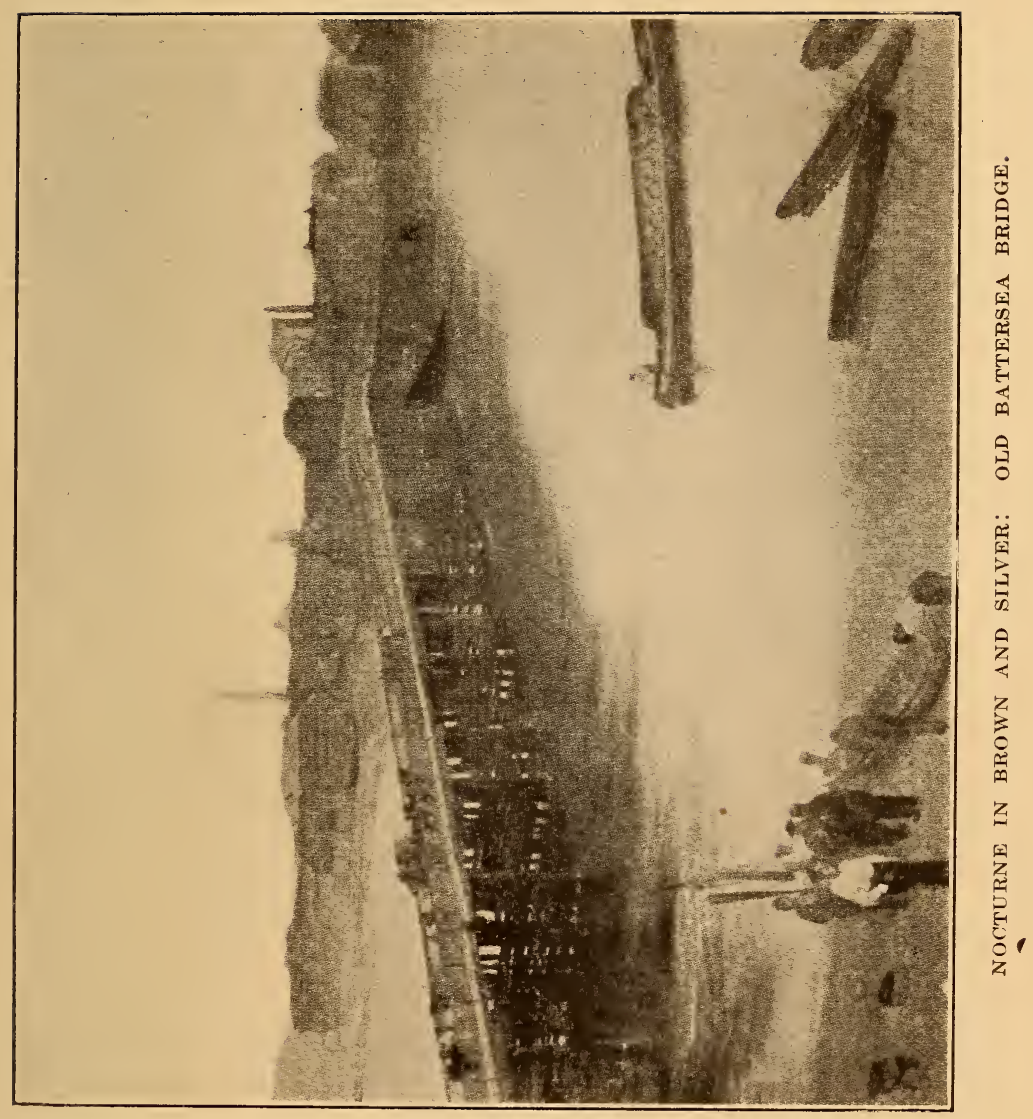



mantle of Whistler's muse may fall, must realize, that it is a vain endeavour - as futile as cloud shadows on a summer day - unless they know that they can hold her, "the capricious jade," as they possess the magic wand to call her.

This was the spirit in which Whistler conceived art. It had long faded out of European art. It was rapidly deteriorating in the Orient. Why could not a single man, even with the whole world against him, live up to some big ideal! To be an artist simply for one's own gratification. To fashion something beautiful simply because one feels like doing it. To purify one's mind by projecting into life what is accumulated there by some curious grace of nature. Whistler undertook the task, and created a new art form that may be destined to rule art for the next thousand years.

A new art form is always the expression of a new spirit. In painting the new spirit is rebellious. In addition it is emphatically individualistic. It is opposed to previous schools and academic training. It aims at attaining the maximum of personal intensity. The exigencies of the classic style - the necessity of a literary subject - at once stay the free use of the brush and hamper the virile expression of technique. Why not give to art a new 
twist, graft upon it a new beauty, enliven it with a purer flame, that it may shine forth again in its old pristine beauty!

The Western mind still rebels that this resurrection should come from the East, through another race. Even the most ardent disciples of Whistler make little of the Japanese influence. It is still a question of conquest. In my mind, as in that of many of our foremost artists, there is not the slightest doubt that the Eastern idea will win out and that a new era, as important as that of Greek influence, will set in. The meaning of the old symbols has faded and it is the artist's duty to create new ones.

Whistler disclosed new harmonies of tone, of arrangement, and visual poetry, all of them sensitive and expressive, using blacks and browns and a touch of vivid colour or a flare of white, and thereby succeeded in stirring the depth of our nature. His art has a tender pallor, tones purposely deadened, faded tints like those on Japanese screens of old feudal castles, of a wondrous harmony and softness. Details, discreetly accentuated, allow the ensemble to retain its full importance, and against dark background, in soft neutral tints, figures that the painter desires to bring out show with an illusion of life truly magical. Herein con- 
sists the last great pictorial invention; it is through this that painting still has the faculty to powerfully address the modern mind.

He said in his "Ten O'Clock" that the story of the beautiful was complete. $\mathrm{He}$ surely, like Monet, has added a valuable chapter. He, in his own words, was " one of the chosen - with the mark of the gods upon him - who had to continue what had gone before." 



\section{BIBLIOGRAPHY}

BACHeR, Отто H.: “ With Whistler in Venice.” New York, 1908.

BeLi, Arthur G. and Nancy: "J. McNeill Whistler and his Work." New York, 1904.

Beld, Nancy E. (Mrs. Arthur Bell): "James McNeill Whistler." London and New York, 1904. (Miniatures Series of Painters.)

Beld, Nancy E.: "Representative Painters of the XIX Century." London, 1899.

BÉNÉdITE, LÉONCE: “L'œuvre de J. McNeill Whistler reunis à l'occasion de l'exposition commemorative." Paris, 1905.

BÉNÉDITE, LÉONCE: “Exposition des œuvres de J. McNeill Whistler." Introduction by Léonce Bénédite. Palais de l'Ecole des Beaux-Arts. Paris, May, 1905.

Bowdorn, W. G.: “James McNeill Whistler.” London, 1901, New York, 1902.

Bowdorn, W. G.: “James McNeill Whistler.” London and New York, 1904.

Brinton, Christian: "Modern Artists." New York, 1908.

Caffin, Chas. H.: “American Masters of Painting." New York, 1902. 
Caffin, Chas. H.: “The Story of American Painting." New York, 1907.

Cary, Elizabeth L.: “The Works of J. McNeill Whistler." New York, 1907.

Chesterton, G. K.: “ Heretics.” London, 1905.

Child, Theodore: "American Artists at the Paris Exposition," "Art and Criticism." New York, 1892.

Child, Theodore: "A Pre-Raphaelite Mansion," "Art and Criticism." New York, 1892.

Copley Society of Boston: "Memorial Exhibition of Works of J. McNeill Whistler. February, 1904."

Cox, Kenyon: “ Old Masters and New.” New York, 1903.

Dennis, G. R.: “Bryan's Dictionary of Painters and Engravers." London, 1905.

Duret, Theodore: “ Histoire de J. McNeill Whistler et de son œuvre." Paris, 1904.

Duret, Theodore: “ Critique d'avant-garde." Paris, 1885.

Eddy, Arthur Jerome: "Recollections and Impressions of J. McNeill Whistler." London, 1903.

Forsythe, Walter Greenwood, Harrison and Joseph Leroy, Ed.: "Guide to the Study of James McNeill Whistler." Albany, 1895 (University of the State of New York). 
Gallatin, Albert E.: “Whistler, Notes and Footnotes and other Memoranda." New York, 1907.

Goodspeed, Charles E.: "Whistler Art Dicta and Other Essays.” Boston, 1904.

Goupil AND Co.: "Portfolio of Twenty-four Reproductions." 1898.

Grolier Club, New YorK: “The Etched Works of Whistler," Compiled by Edward G. Kennedy, introduction by Royal Coutissoz. 1910.

Hollingworth, C. J. H.: “The Peacock Room." Obach Galleries. London, 1904.

Hartmann, Sadakichi: "A History of American Art," Vol. 2. Boston, 1902.

Hubbard, Elbert: “ Whistler." East Aurora, N. Y., 1903 (Little Journey Series).

Hursman, J. K.: “Certains.” (G. Moreau, Degas, Cheret, Whistler, Rops, etc.) Paris, 1889.

International Society of Sculptors, Painters AND Engravers: "Memorial Exhibitions of the Works of the Late J. McNeill Whistler." London, Feb. 22nd to April 15th, 1905.

Isham, Samuel: "The History of American Painting.” New York, 1905.

Knoor, Thomas: "James McNeill Whistler," Zehnuhr Vorlesung. Strassburg, 1904.

Koehler, Sylvester Rosa: “Etching." New York, 1885.

Lety, Florence: “Whistler Catalogue." Metropolitan Museum, N. Y.; 1910. 
McFald, Haldane: “Whistler: Butterfly, Wasp, Wit, Masters of Arts, Enigma." Boston, 1907.

McFall, Haldane: “Whistler." Boston, 1906 (Spirit of Age Series).

Mansfield, Howard: “A Descriptive Catalogue of the etchings and drypoints of James Abbott McNeill Whistler." Chicago, Caxton Club, 1909. Mauclair, C.: “De Watteau à Whistler.” Paris, 1905.

MacCold, Donald Stewert: “Nineteenth Century Art: James McNeill Whistler." Glasgow, 1902.

McSpadden, J. Walker: "Famous Painters of America." New York, 1907.

Menpes, Mortimer: "Whistler As I Knew Him." London, 1904.

Moore, George: “Modern Painting." London, 1898.

Muther, Richard: “A History of Modern Painters." London, New York, 1907.

Pattison, James William: “Painters since Leonardo." Chicago, 1904.

Pennell, E. R. and J.: "The Life of J. McNeill Whistler." London, 1908.

Rossetti, William Michael: "Fine Arts, Chiefly

Contemporary," Vol. 3. New York, 1896.

Singer, HaNs W.: “James McNeill Whistler." Berlin, 1904, London, 1908 (Langham Series).

Studio: “Whistler Portfolio." London, 1905. 
Symons, Arthur: "Studies in Seven Arts." New York, 1906.

Ralph, Thomas: "Catalogue of etchings and drypoints of J. McNeill Whistler." London, 1874.

Tuckerman, H. T.: “ Book of Artists.” New York, 1867.

Victoria and Albert Museum: "The Etchings of J.McNeill Whistler." (Catalogue.) London, 1905.

Vose, George L.: "Sketch of the Life of George Washington Whistler, Civil Engineer." Boston, 1887.

Way, Thomas R.: “Whistler's Lithographs.” London, 1896.

WaY, R., and Dennis, G. R.: “The Art of J. McN. Whistler: An Appreciation." London, 1903.

Wedmore, Frederick: "Whistler's Etching; A Study and A Catalogue." London, 1886.

Wedmore, Frederick: “A Note on Etchings by Whistler, Exhibited at the Galleries of Obach and Co." London, 1903.

Wedmore, Frederick: “Four Masters of Etching (Whistler, Legros, Seymour Haden and Jacquemart)." London, 1883-89.

Wedmore, Frederick: "Whistler and Others" (24 Essays). London and New York, 1906.

Whistler, J. McN.: “Eden v. Whistler," "The Baronet and the Butterfly," "A Valentine with a Verdict." Paris, 1899. 
Whistler, J. McN.: “ The Gentle Art of Making Enemies." London, 1890. New edition, 1892, includes Whistler's “ Ten O'Clock."

Whistler v. Ruskin: “The Painter Etcher Papers and the Nocturnes, Marines and Chevalet Pieces."

Whistler v. Ruskin: "Nocturnes, Marines and Chevalet Pieces." London, 1892.

Whistler v. Ruskin: "Paddon papers, or the Owl and the Cabinet." London, 1882.

Whistler $v$. Ruskin: "Piker Papers."

Whistler $v$. Ruskin: “Mr. Whistler's Ten O’Clock.” London, 1888.

Whistler v. Ruskin: "Art and Art Critics," "The White House." Chelsea, London, December, 1878.

Whistler $v$. RUSKin: "Whistler Album" (20 photographs). Paris, 1892.

Whistler $v$. Ruskin: “Wilde $v$. Whistler: being Acrimonious Correspondence." London, 1896. 


\title{
PRINCIPAL MAGAZINE ARTICLES
}

\author{
Alden, W. S. . . . . Saturday Review . . Aug. 1903. \\ Alexandre, Arsène . . Les Arts . . . . . . Sept. 1903. \\ American Architect . Nov. 1887. \\ Art Journal . . . v. 49, p. 10. \\ Art Journal … v. 52, p. 198. \\ Art Journal . . . v. 49, p. 298. \\ Bacher, Otto . . . Century Magazine . 1902, p. 100-111. \\ Baldry, A. L. . . . The Studio . . . . Sept. 1903. \\ Beal, S. . . . . . American Architect . v. 81, p. 91. \\ Beerbohm, Max . . Metropolitan . . . 1904, p. 728-733. \\ Beerbohm, Max . . . Saturday Review . . Nov. 1897. \\ Bênédite, Léonce . . Gazette des beaux-arts 1905, p. 33-34. \\ Bloor, A. J. . . . . Critic . . . . . 1903. \\ Brinton, Christian . . Critic . . . . . . 1902. \\ Brinton, Christian . . Munsey's Magazine . 1906. \\ Brownell, W. C. . . . Scribner's Magazine . Aug. 1879. \\ Boughton, G. H. . . International Studio. 1904, p. 210-218. \\ Caffin, Charles H. . . International Studio 1903, v. 20. \\ Coburn, Fred. W. . . Brush and Pencil . . 1904, v. 13. \\ Cortissoz, Royal . . Atlantic Monthly . 1903, v. 92, pp. \\ $826-838$. \\ Cox, Kenyon . . . . Nation Magazine . . 1904 v. 78. \\ Crawford, Earl Stetson The Reader . . . 1903, v. 2, pp. \\ 387-390. \\ Current Literature . Sept. 1903. \\ Dempsey, Charles W. Magazine of Art . . 1882, p. 358. \\ Dempsey, Charles W. McClure's Magazine . v. 7, p. 374. \\ Dodgson, Campbell . Graphische Künste . 1904. \\ Dowdeswell, W. . . . American Architect . v. 22, p. 258. \\ Dreyfus, Albert . . . Kunst für Alle . . . 1907. \\ Eclectic Magazine . 1903, v. 10, pp. \\ $556-558$.
}


Fenellosa, Ernest F. . Lotus Magazine . . 1903.

Finberg, A. J. . . . Athenæum Magazine 1902-3.

Fortuny, Pascal . . . Gazette des beaux-arts 1903, v. 30.

Fourcaud, L. de . . . Gazette des beaux-arts June, 1884.

Geffroy, Gustave . . Revue Universelle . Sept. 1903.

Hadley, Frank H. . . Brush and Pencil . . 1903, v. 12. Harper's Weekly . . Aug. 1903.

Hartmann, Sadakichi Wilson's Magazine . Apr. 1910.

Hawthorne, Julian . Independent Magazine Nov. 1899.

Hubbard, Elbert . . Idler Magazine . . . 1903, v. 23. International Studio 1905, v. 25.

Jenney, W. L. B. . . American Architect . v. 59, p. 4.

Jackson, Louise W. . Brush and Pencil . . 1908.

Kelley, G. . . . . . Weston's Magazine . v. 130.

Kessler, Harry G. . . Kunst und Künstler . 1905.

Knaufft, Ernest . . . Churchman Magazine 1903.

Knaufft, Ernest . . . Review of Reviews . v. 28, p. 173.

Kobbê, Gustave . The Chap Book . . 1898.

Kunst und Künstler . 1905.

Kunst und Künstler . 1908.

Levin, Julius . . . . Illustrirte Zeitung . 1903.

Living Age . . . 1905, v.28 (v. 246).

Losee, William F. . . Brush and Pencil . . 1903, v. 12.

Ludovici, A. . . . Art Journal . . . 1906, v. 68.

Masters in Art . . 1907, v. 8.

Macfall, H. . . . . . Academy . . . . v. 66, p. 633.

Mather, Frank, Jr. . World's Work . 1903.

Matsuki, Bunkio . . Lotus Magazine . . 1903.

Mauclair, Camille . . Rev. Polit. and Litter. 1903, v. 20.

Mans, Octave . . . . International Studio 1904, v. 23.

Meier-Graefe, Julius . Die Zukunft . . . 1903.

Menpes, Dorothy . . International Studio 1904, v 20, pp.

245-257.

Menpes, Mortimer . . Cornhill Magazine . 1903, v. 15.

McColl, D. S. . . . . Art Journal . . . v. 15, p. 88.

McColl, D. S. . . . . Saturday Review . . v. 13, p. 357.

Meynell, Wilfred . . Pall Mall Magazine . 1903, v. 31. 


\begin{tabular}{|c|c|}
\hline $\begin{array}{l}\text { Morton, Fred. W. . } \\
\text { Mulliken, Mary A. . } \\
\text { Muster, John de }\end{array}$ & $\begin{array}{l}\text { Brush and Pencil . . 1903, v. } 12 . \\
\text { International Studio } 1905, \text { v. } 25 . \\
\text { Elseviers Geillust . . 1907, v. } 33 . \\
\text { The Nation . . . 1903, pp. } 149-151 .\end{array}$ \\
\hline Patini, Rinaldo . & Nuova antologia . 1909, v. 140. \\
\hline Pennell, Joseph & Burlington Magazine \\
\hline Pennell, Joseph . & Nation . . . v. 54 , p. 280. \\
\hline Pennell, Joseph & $\begin{array}{l}\text { North American Re- } \\
\text { view . . . . * * 1903, v. } 177 . \\
\text { Scribner's Magazine } \\
\text { v. } 21, \text { p. } 277 .\end{array}$ \\
\hline Pennington, Harper & International Quar'ly 1904 , v. 10, No.1. \\
\hline Pennington, Harper & Metropolitan Magazine 1910, pp. 769-776. \\
\hline Princep, Val . & Magazine of Art $\quad . \quad 1903$. \\
\hline Quilter, Harry & $\begin{array}{l}\text { Chamber's Magazine 1903, v. } 66 . \\
\text { Revista Latino Ameri- } \\
\text { cana . . . . . . . 1903, v. } 1 .\end{array}$ \\
\hline Rosenhagen, Hans & $\begin{array}{l}\text { Nord und Süd . . . } 1909, \text { v. } 130 . \\
\text { Saturday Review . . } \\
\text { v. } 3 \text { p. } 208 .\end{array}$ \\
\hline Scott, William . & International Studio 1903, pp. 97-107. \\
\hline Sickert, Bernhard & Burlington Magazine 1905, v. 6. \\
\hline Sickert, Oswald . & International Studio 1903, v. 21. \\
\hline Sickert, Oswald . & Kunst und Künstler . 1903, v. 1. \\
\hline Sickert, Walker . . & Fortnightly Review . v. 54, p. 243. \\
\hline Sketchley, R. E. D. & Kunst und Künstler 1906, v. 4. \\
\hline Smalley, Phoebe J. & The Lamp . . . . . v. 27, p. 110 \\
\hline Spielmann, M. H. . & $\begin{array}{c}\text { Magazine of Art . Nov. } 1903, \text { pp.69- } \\
70 .\end{array}$ \\
\hline Swinburne, A. C. & Fortnightly Review . v. 49, p. 745. \\
\hline burne, A. C. & Ecclesiastic Magazine v. 111 , p. 154. \\
\hline Teall, Gardner C. & The Bookman . . . 1903, pp. 265-268 \\
\hline Thompson, D. . & 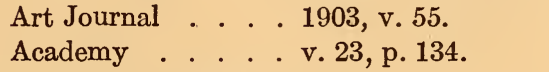 \\
\hline Wedmore, Fred. & $\begin{array}{l}\text { 19th CenturyMagazine 1904, v. } 21 . \\
\text { Knowledge . . . v. 3, p. } 208 .\end{array}$ \\
\hline $\begin{array}{l}\text { Way, Thomas R. } \\
\text { Wuerpel, G. H. }\end{array}$ & International Studio 1903. \\
\hline Wilson, $\mathrm{T}$. & $\begin{array}{l}\text { Independent . . . . v. 56, p. } 131 . \\
\text { Book Buyer . . . v. 17, p. } 113 .\end{array}$ \\
\hline
\end{tabular}




\section{PRINCIPAL PAINTINGS*}

La Fumette . . . . . . . . . . . p. 1859.

Self-portrait . . . . (S. P. Avery, Esq.) . . p. 1859.

La Mère Gérard . . . . . . . . . . p. 1859.

The Music Room . . . (Frank J. Hecker, Esq.) p. 1860.

The Woman in White . (J.H. Whittemore, Esq.) p. 1863 e. 1863.

Lange Leizen of Six

Marks: In Purple and

Rose . . . . . . . (John G. Johnson, Esq.) p. 1864 e. 1864.

Harmony in Purple and

Gold: The Golden

Screen . . . . . (Chas. W. Freer, Esq.) p. 1864 e. 1865.

Symphony in White II:

The Little White Girl (Arthur Studd, Esq.) p. and e. 1864.

Symphony in White III (E. Davis, Esq.) . . . .

At the Piano . . . . (E. Davis, Esq.) . . . p.1859e.1867.

La Princesse du Pays

de la Porcelaine . . (Chas. W. Freer, Esq.) p.1864 e.1865.

On the Balcony: Harmony in Flesh Colour and Green. . . . . (Chas. W. Freer, Esq.) . e. 1866.

Self-portrait . . . . . (George McCullough,Esq.) p. 1867.

Arrangement in Black: (Chas. W. Freer, Esq.) e. 1873

F. R. Leyland.

Arrangement in Brown

and Gold . . . . (J. J. Cowan, Esq.) . .

* p. indicates when picture was painted, or started, as it sometimes took Whistler more than ten years to finish a picture; e. indicates when first exhibited. Dates and ownership are omitted whenever author failed to verify facts. 
Woman in Gray . . . (Riks Museum, Amsterdam)

Lady in Gray . . . . (Metropolitan Museum, New York)

L'Andalusienne . . (John H. Whittemore, Esq.)

Arrangement in Black

p. about 1894 . and Brown: Miss

Rose Corder . . . (R. A. Canfield, Esq.) . p. 1876 e. 1881.

The Peacock Room . . (Chas. W. Freer, Esq.) 1876.

Arrangement in Black and Brown: The Fur Jacket . . . . : (William Burrell, Esq.) p. 1876. Americaine . . . . . . . . . . . . p. 1876 e. 1878.

Florence Leyland . . (Brooklyn Institute,

Arrangement in Gray and Black: Thomas (City Art Galleries, GlasCarlyle . . . . gow) . . . . . p.1872 e. 1877.

Sir Henry Irving as Philip II . . . . . . . . . . . . . e. 1877.

Arrangement in Gray and Black: The Artist's Mother . . . (Luxembourg Gallery) p. 1871 e. 1881.

Arrangement in Gray and Green: Miss Alexander . . . . (W. C. Alexander, Esq.) p. 1872 e. 1881.

Arrangement in Black and White: Lady Meux ． . . . . . . p. 1877 e. 1884. Harmony in Pink and Gray: Lady Meux . . . . . . . . . e. 1882.

Theodore Duret . . . . . . . . . . e. 1883.

Arrangement in Black: Lady Archibald Campbell . . . . . . (Wilstach Gallery,Phila.) e. 1883. Mrs. Louis Huth . . . . . . . . . p. 1877 e. 1884. 
Arrangement in Black:

Mme. Cassatt . . . . . . . . . . . e. 1855.

Arrangement in Black: (Carnegie Art Institute,

Pablo Sarasate . . Pittsburg, Pa.) . . . p. 1884 e. 1886.

Harmony in Ivory:

Lady Colin Campbell . . . . . . . . . . e. 1866.

Arrangement in Violet

and Rose: Mme.

Walter Sickert . . . . . . . . . . e. 1887.

Arrangement in Black

and Gold: Comte de

Montesquiou .. . (R. A. Canfield, Esq.) e. 1891.

The Master Smith of

Lyme Regis . . . . (Boston Museum) . . e. 1895.

Little Rose of Lyme

Regis . . . . . (Boston Museum) . . . e. 1895.

Full length Self-portrait (G. W. Vanderbilt, Esq.) e. 1900. 


\section{NOCTURNES}

The majority of Nocturnes were painted during the years 1866-1884.

Nocturne in Blue and Gold: Valparaiso . . . . . . . p. 1866 e. 1871. (Chas.W. Freer, Esq.)

Symphony in Gray and Green: The Ocean ... . . . . . p. 1871. (R. A. Canfield, Esq.)

Crepuscule in Flesh Color and Green: Valparaiso . . . . . . . . p. 1871.

Nocturne in Blue and Silver: Batter- p.1877. (Chas. W. Freer, sea Reach . . . . . . . . . Esq.)

Nocturne in Blue and Silver ... p. 1877.

Nocturne in Blue and Gold: Old Battersea Bridge . . . . . . . (Tate Gallery, London.)

Nocturne: Trafalgar Square, Snow.

Nocturne in Blue and Silver: Bognor. (Chas. W. Freer, Esq.)

Nocturne in Opal and Silver: The Music Room.

Nocturne in Gray and Gold: Chelsea, Snow.

Nocturne in Gray and Gold: Westminster Bridge.

Nocturne in Blue and Gold: Southampton Waters . . . . . . . (Art Institute, Chicago.)

Nocturne in Brown and Silver: Old Battersea Bridge.

Nocturne in Blue and Gold: St. Mark's, Venice.

Pink and Gray: Chelsea . . . . (Lord Battersea) 
Nocturne in Black and Gold: The p. 187 (Mrs. S. UnterFalling Rocket myer)

Cremorne Gardens . . . . . (Metropolitan Museum, N.Y.)

An Orange Note: Sweet Shop. 


\section{INDEX}

Abbey, Edwin A., 37

Adam and Eve Tavern, 153

Adams, Clifford, 72

Alexander, Portrait of Miss, $109,124,137-138,139$, 238

"Americaine, La Belle," 134, 237,238

Appian, 152

Amsterdam Canal, 154

Annual Review at Spithead, 157

Armstrong, 219

Arrangements, 21, 116, 129

Artist's Mother, Portrait of the, $8,21,29,31,41,76,90$, $109,124,136,137,143$, 144-146, 176, 234

At the Piaro, 3, 17, 122-123

Aubrey, 110

Avery, S. P., 219

Bacher, Otto H., 155-156, 221

Balleroy, De, 17

Balzac, 94

Barber, The, 158

Battersea Bridge, 153

Baudelaire, 17

Bayliss, Wyke, 190

Becquet, 153

"Belle Dame Paresseuse, La," 175

"Belle New-Yorkaise, La," 175

Besnard, 85, 89

Bing, 45

Binyon, Laurence, 210

Blue Wave, The; Biarritz, 42

Böcklin, 69

Bognor, 40

Boldini, 138, 230, 236
Bonvin, 17

Bracquemond, 17, 18

Burne-Jones, 72, 193, 236

Butterfly Monogram, The, 39$41,56-57$

Cadogan Pier, 162

Campbell, Portrait of Lady Archibald, 3, 4, 5, 27, 124, 128, 137, 238

Canaletto, 151

Canfield, R. A., 73, 128

Caprice, 177

Caprices, 21

Caravaggio, 93

Carlyle, Thomas, 23, 110, 138

Carlyle, Portrait of Thomas, 8, $76,109,136,137,143,144$

Carrière, 69, 90, 96

Carte, D'Oyle, 110

Casanova, 196

Cassatt, Portrait of Mme., 124

Cazin, 18, 68, 69

Cellini, Benvenuto, 196, 231

Cernuschi, 45

Cézanne, 247

Champfleury, 17

Chandler, Rob, 104

Chardin, 87

Chase, William M., 191, 201

Chavannes, $55,68,69,76,202$, 204

Chelsea, 3, 70, 153

Cheret, 47

Chevalet Pieces, 29

Chevreul, 87

Child, Theodore, 191

Church, F. E., 76

Cimabue, 35 
Clews, 247

Colarossi, 42

Collins, Wilkie, 187

"Confidences dans le Jardin, Les," 175

Constable, 90, 134, 203

Corder, Portrait of Rose, 124, 128-129, 137

Cordier, 17

Corot, 69

Courbet, 17, 18, 42, 43, 64, 79

"Cuisine, La," 149

Dabo, Leon, 34, 90

Dagnan-Bouveret, 69

Dam Wood, The, 162

Dancing Girl, 173

Dannat, 84

Daubigny, 75

David, 78

Dawson, Daniel, 242

Degas, 18, 85, 87, 89

Delacroix, 17, 87, 133

Delaroche, 78

Delâtre, 166

Delonney, 150

Denton, Watts, 221

Doorway, 154

Drouet, 219

Drouet, Portrait of, 153

Du Maurier, 16, 192, 218, 219

Duran, Carolus, 33

Duranty, 17

Dürer, 147, 148, 203

Duret, Theodore, 37, 125, 173

Duret, Portrait of Theodore, $124,136,137,138,139$, 143

Duveneck, Frank, 190

Eden, Sir William, 190, 191

Elsheimer, 94

Etchings, 7, 27, 28, 66, 116, 149-154, 158-162, 166167

Eugenie, Empress, 16, 18

Early Morning, 175
Falling Rocket, The, 24, 58-60

Fantin-Latour, 13, 16, 17, 172, 229

Flaubert, 80

Ford, Sheridan, 30, 100, 182, 195

Fortuny, 236

Fragonard, 133

France, Anatole, 208

Freer, Charles W., 36, 37, 50, 229

Frith, W. P., 191

Fromentin, 186

Fuller, 239

Fumette, 17

Fur Jacket, The, 124, 128, 137, 238

Gainsborough, 138, 203

Garden, The, 66, 151

"Gentle Art of Making Enemies, The," 8, 30, 40, 182

Girl on a Couch, 153

Gleyre, Charles, 12, 41-42

Godwin, Edwin W., 8, 37

Golden Screen, The, 50, 51

Goncourt, Edmond and Jules de, $45,80,206$

Goya, 79

Gozzolli, 124， 125

Grain, Corney, 108

Grand Gallery of the Louvre, The, 174

Gray, Walter, 226

Greaves, 227

Guimet, 45

Guthrie, Sir James, 37

Haden, F. Seymour, 9, 17, 44, $122,155,190$

Hals, Franz, 79, 91, 122, 134, 141

Hamerton, P. G., 153, 190

Harmonies, 21, 28, 29, 44, 116, $118,129,178$

Harpignies, 18

Harrison, Alexander, 225

Harunobu, 147, 148 
Hawkins, C. R., 191, 235

Hawthorne, 247

Hecker, Frank J., 44

Heffernan, Joanna, 51-52

Heine, Heinrich, 49, 151

Hellew, 230

Helmholtz, 87

Henley, Portraits of $M r$. and Mrs. W. E., 176

Henner, 69, 93

Henri, Robert, 91, 247

Heyse, Paul, 206

Herrick, 172

Hiroshige, 40, 51, 53, 62, 66, 67

Hogarth, 37, 203

Hokusai, 148

Homer, Winslow, 239

Horsley, R. A., 177

Hôtel de Ville at Loches, 151

House Beautiful, see White House

Huddleston, Judge, 194

Huth, Portrait of Mrs., 124, 137

Ingres, 12, 64, 78, 147

Inness, 201

Ionides, Luke, 218

Irving as Philip II., Portrait of Sir Henry, 124, 136

Israels, 64, 134, 202, 236

Jacquemart, 152

Jameson, Mrs., 220

Jo, 52, 153

Johnson, John G., 49

Jongkind, 18

Julian, 42

Keene, Charles, 195

Kennedy, 192

Khnopff, 90

Kiyonaga, 46

Klinger, 153

Lalanne, 152

Lalouette, Madame, 13

Lange-Leizen of the Six Marks, 49,50

Lannion, $A, 178$
Lautrec, Toulouse, 47

Lavery, John, 37, 90

Legros, 13, 16, 17, 191

Leighton, Sir Frederick, 64, 69, 191, 192, 193

Lenbach, 83, 236

Leonardo da Vinci, 16, 79, 90, 92

Lessing, 186

Leyland, F. R., 9, 22, 54, 103, $104,105,157,190,211$, 223

Leyland, Portrait of Florence, $124,129-130,134,139$

Leyland, Portrait of F. R., 124, $127-128,140,143$

Lime Burner, The, 66

Lindsey, Sir Coutts, 193, 194, Lion's Wharf, 153

Lithographs, 8, 27, 29, 172-178

Little Mast, The, 158

Little Nude Reading, The, 178

Little Pool, The, 162

Little Rose of Lyme Regis, 175

Little Venice, 151

Little Wapping, 162

Little White Girl, The, 49, 5253,123

Locksmith of the Dragon Square, The, 175

London Bridge, 158

Long Lagoon, The, 162

Lorraine, Claude, 151

Ludovici, A, 224

Luks, 247

Luxembourg Gardens, The, 174

"Maison Jaune, La," 178

"Maison Rouge a Paimpol, La," 178

Makart, 134

Mallarmé, Stéphane, 176, 206, 209

Mallarmé, Portrait of Stéphane, 175-176

Mancini, 247

Manet, 17, 18, 19, 87, 90, 141, 204,243 
Mantz, Paul, 19

"Marchande de Moutarde, La," 149

Marines, 29

Maris, 71, 247

Martin, Homer, 239

Master Smith, The, 175

"Maud," 110

Maupassant, Guy de, 206

Max, Gabriel, 124

McCullough, George, 229

Memling, 133

Menpes, Mortimer, 195, 197, 222

Meredith, George, 3, 23

"Mère Gérard, La," 17, 149

Meux, Portraits of Lady, 27, $124,133,137$

Meyrion, 153, 154

Millais, 193

Model resting, The, 153, 178

Monet, $75,79,87,90,141$, 142, 204, 244

Montesquiou de Fezensac, Comte, 195, 237

Montesquiou de Fezensac, Portraits of Comte, 27, 142143,176

Monticelli, 136, 247

Moore, Albert, 229

Moore, George, 191

Morning Call, The, see Music Room, The

Morris, William, 100-102

Murger, Henri, 13

Music Room, The, 42, 44

Napoleor III, 18

Nocturnes, 21, 24-25, 28, 29, $40,59-61,67,71-80,118$, $193,226-228$

Notes, 21, 28, 29, 118

Ocean, The, 39, 67

Old Battersea Bridge, 3, 59, 67, 70

Old Hungerford Bridge, 162
On the Balcony (Terrace), 50, $54-55,70,154$

Outomaro, 46, 49, 54, 64

Palace, 154

Palmer, Emma, 216

Pantheon, 174

Pastels, 7, 28, 178-179

Peacock Room, 21, 54, 103, 104-105, 211

Peladan, Mérodack, 147

Pelligrini, Carlo, 195

Pennell, Joseph, 105, 125, 139, $153,157,166-167,196$, $216,226,229,230$

Pennell, Portraits of Mr. and Mrs. Joseph, 176

Pennington, Harper, 107, 211 "Pepys' Diary," 9

Philip, John Bernie, 8

Philip, Portrait of Miss, 176 Pinturicchio, 133

Pissaro, 18

Poe, Edgar Allan, 11

Pool, The, 151

Price's Candle Works, 151

Princess of the Porcelain Land, $50,54,65,103,123$

Prinsep, Val, 191, 223

Prudhon, 93

Quilter, Harry, 113-114, 190

Raffaelli, Jean François, 6, 86, 124,153

Raphael, 91, 147, 246

Regamey, 45

Reid, 247

Rembrandt, 18, 79, 81, 82, 91, $95,98,149,152,199,203$, 246

Renoir, 89, 95, 247

Ribera, 93

Ribot, 16, 134

Riva, The, 158

Robertson, Graham, 128 
Rodin, 94

Rood, Ogden, 87

Rops, 153

Rossetti, Dante Gabriel, 23, $34,54,191,221$

Rossetti, W. M., 103, 228

Rossi, Mme. Carmen, 33

Rousseau, 75

Rowley, 219

Roybet, 134

Rubens, 13, 65, 133, 219

Ruskin, John, 24, 58-60, 72, $87,117,151,177,193-194$

Ryder, 71, 201

San Biagio, 151

Sarasate, Pablo de, 22, 110, 113,195

Sarasate, Portrait of Pablo de, $27,97,124,136,139-140$, 145

Sargent, 84, 141, 201

Scene in Alsatian Village, 150

Schalcken, 82

Segantini, 236, 247

Sharaku, 46

Shunsho, 46

Sickert, Portrait of Walter, 176

Silent Canal, The, 153

Singer, H. W., 196

"Soupe à Trois Sous," 153

Southampton Docks, 153

Southampton Water, 70

Spartali, Christie, 54

Spencer, Herbert, 85

Starr, Sidney, 140

Steichen, 94

Stevens, 42, 43-44, 103，123

St. Mark's, Venice, 70

Stott, 191

Street at Saverne, 150

Studd, Arthur, 49

Sutherland, 106

Swinburne, 23, 53,191

Symphony in White, A, 19, 42, 50. 189 , see also Woman in White

Symphonies, 21, 39, 40, 42
Tadema, Alma, 42

Taine, H., 81

Tanyu, 148

Tarbell, 247

Taylor, Tom, 190

“"Ten O'clock," 8, 61, 182, 186, 198-200, 251

Terborg, 93

Thayer, Abbott, 201, 239

Thomas, Percy, 225

Thomas, Ralph, 229

Thompson, Sir H., 22

Tintoretto, 65

Tissot, 12, 95, 133, 134

Titian, 65, 81, 91, 95, 130, 133, 168

Tryon, 68,69

Turner, 75, 87, 151

Unsafe Tenement, 153

Valparaiso Harbour, 20-21, 59, 70

Vanderbilt, George W., 37, 230

Van der Helst, 18

Van Dyke, 79, 82, 122

Van Rensselaer, Mrs. Schuyler, 167

Variations, 21

Velasquez, 11, 42, 79, 95, 97, $124-125,132,134,142$, $192,203,231,243$

Velvet Dress, The, 162

Vermeer, 18

Vernet, 78

Veronese, 168, 169, 246

Veyrasset, 153

"Vieille aux Loques, La," 149

View on the Thames, 173

Vollon, 18

Watteau, 87

Way, Thomas, 174, 176, 229

Wedmore, Frederick, 166, 174, 190

Westminster Bridge, 70

Whistler George Washington, 9-11 


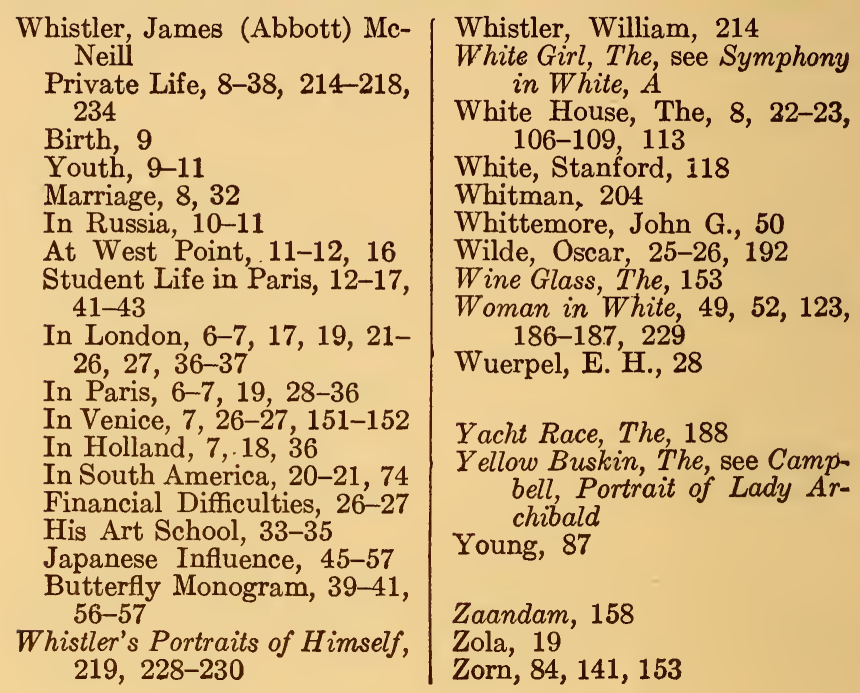




-

, 
